\title{
ipen
}

INSTITUTO DE PESQUISAS ENERGÉTICAS E NUCLEARES

Autarquia Associada À Universidade de São Paulo

\section{DESENVOLVIMENTO E FARMACOCINÉTICA DE ANTIMÔNIO \\ ENCAPSULADO EM LIPOSSOMAS DE FOSFATIDILSERINA UTILIZANDO \\ RADIOISÓTOPOS EM LEISHMANIOSE EXPERIMENTAL}

SAMANTA ETEL TREIGER BORBOREMA

Tese apresentada como parte dos requisitos para obtenção do Grau de Doutor em Ciências na Área de Tecnologia Nuclear - Aplicações

Orientadora:

Prof $^{\mathrm{a}}$ Dra. Nanci do Nascimento 


\section{ipen}

INSTITUTO DE PESQUISAS ENERGÉTICAS E NUCLEARES

Autarquia Associada À Universidade de São Paulo

\section{DESENVOLVIMENTO E FARMACOCINÉTICA DE ANTIMÔNIO \\ ENCAPSULADO EM LIPOSSOMAS DE FOSFATIDILSERINA UTILIZANDO \\ RADIOISÓTOPOS EM LEISHMANIOSE EXPERIMENTAL}

SAMANTA ETEL TREIGER BORBOREMA

Tese apresentada como parte dos requisitos para obtenção do Grau de Doutor em Ciências na Área de Tecnologia Nuclear - Aplicações

Orientadora:

Prof $^{\mathrm{a}}$ Dra. Nanci do Nascimento 


\section{AGRADECIMENTOS}

A Prof ${ }^{a}$ Dra. Nanci do Nascimento, minha orientadora, pela confiança em todos os momentos de meu trabalho, pela sua orientação constante e flexível, pela sua amizade e apoio.

Ao Prof". Dr. Heitor Franco de Andrade Jr (IMTSP), meu "co-orientador", pelos ensinamentos e desafios, pela paciência, confiança e incentivo em todos os momentos de minha formação científica.

Ao Profo. Dr. João Alberto Osso Jr (IPEN), que me acolheu gentilmente em seu laboratório, que cada momento encorajou-me a concretizar este trabalho, pela colaboração e ensinamentos durante todo o tempo.

Ao Prof ${ }^{o}$ Dr. Reto Albert Schwendener, que me permitiu realizar o Doutorado-Sanduíche no seu Laboratório de Pesquisas em Lipossomas (IMCR-Suíça), pelos preciosos ensinamentos sobre lipossomas e pela sua assistência e ajuda por todo o meu trabalho e minha estadia na Suiça.

Ao Prof ${ }^{o}$ Dr. Sushil Kumar (IMCR - Suíça) por sua assistência em todas as experiências realizadas e por responder a todas as minhas perguntas com atenção e paciência.

As todas as pessoas do Laboratório de Pesquisas em Lipossomas (IMCR-Suíça), AnneKatrine, Caroline, Janny e Sibel pela ajuda que me deram durante o tempo que estive na Suiça e principalmente pela a atmosfera de trabalho agradável.

Ao Björn Studer do Instituto de Ecologia Terrestre - Proteção do Solo (ETH-Suíça) pela imensa ajuda na determinação antimônio por Voltametria de Pulso Diferencial e pelo bom convívio social.

A Creuza F. H. Takakura do Departamento de Doenças Infecciosas e Parasitárias da FMUSP, pelo auxilio na caracterização morfológica dos lipossomas por microscopia eletrônica de transmissão.

A Lipoid GmbH, Ludwigshafen, GE, pela gentil doação dos fosfolipídios.

Ao Prof ${ }^{o}$ Dr. André Gustavo C. Tempone (IAL) pelos primeiros ensinamentos sobre lipossomas, pelas discussões científicas e amizade.

Aos amigos do Laboratório de Protozoologia (IMTSP), Andrés, Barbara, Bruna, Camila, Cláudia, Dona Francisca, Felipe, Ivani, Juliana, Luciana, Luciano, Maria, Miriam, Naiara, Rose, Solange e Sônia pela amizade, auxilio mútuo e bom convívio durante todos os anos.

Aos amigos do Biotério (IPEN), em especial à Neide pela ajuda e colaboração durante toda a realização dos experimentos.

As amigas da Diretoria de Radiofarmácia (IPEN), Bárbara, Carla, Giovana, Graciela, Paula, Renata, Tânia e Vanessa, pela amizade e apoio durante o trabalho. 
A amiga Patrícia da Gerência de Controle de Qualidade de Radiofármacos (IPEN), pelo auxílio na determinação de antimônio por ICP-OES.

A amiga Kátia da Diretoria de Radiofarmácia (IPEN), pela imensa compreensão e ajuda na determinação de antimônio por AAN.

A Prof ${ }^{a}$ Dra. Maria do Carmo Sampaio Tavares Timenetsky e a Prof ${ }^{a}$ Maria Akiko Ishida (IAL), por permitirem o meu afastamento a fim de concluir este trabalho.

Ao Instituto de Pesquisas Energéticas e Nucleares pela oportunidade concedida para a realização deste trabalho.

Ao CNPq e ao LIM-49 (IMTSP), pelo apoio financeiro, provendo todos os recursos necessários para a realização deste trabalho

As minhas irmãs, Beatriz e Brana, pelas idéias, incentivo, carinho e dedicação durante toda a minha vida.

Ao meu namorado, Ademar, pela paciência, compreensão, incentivo, carinho e atenção constante durante a elaboração deste trabalho.

Meu eterno agradecimento aos meus pais, José Luis e Márcia, que sem medir esforços em suas vidas, me transmitiram todo o carinho, amor incondicional, sustento, incentivo, apoio e equilíbrio para o meu crescimento. Sem vocês o meu trabalho não seria realizável...

A todos aqueles que mesmo não citados, mas que me acompanharam de certa forma no desenrolar deste meu desafio, que puderam contribuir à sua maneira na realização deste trabalho. 


\title{
DESENVOLVIMENTO E FARMACOCINÉTICA DE ANTIMÔNIO ENCAPSULADO EM LIPOSSOMAS DE FOSFATIDILSERINA UTILIZANDO RADIOISÓTOPOS EM LEISHMANIOSE EXPERIMENTAL
}

\author{
Samanta Etel Treiger Borborema
}

\begin{abstract}
RESUMO
Leishmanioses são um complexo de doenças infecciosas causadas por protozoários intramacrofágicos do gênero Leishmania, fatal se não tratadas adequadamente. Os antimoniais pentavalentes são os medicamentos de primeira escolha para o tratamento, apesar de sua toxicidade e seu mecanismo de ação pouco esclarecido. Uma terapia mais eficaz pode ser conseguida pelo direcionamento de fármacos antileishmania para os locais de infecção. Os lipossomas são vesículas lipídicas que promovem melhora na eficácia e na ação de fármacos na célula alvo. Os lipossomas são capturados preferencialmente pelas células do sistema mononuclear fagocitário (SMF). O objetivo deste estudo foi desenvolver uma formulação de antimoniato de meglumina lipossomal, constituído por fosfatidilserina e estudar sua farmacocinética em animais sadios para esclarecer seu metabolismo e distribuição. As análises quantitativas de antimônio em lipossomas demonstram que Análise por Ativação Neutrônica foi a técnica mais sensível com cerca de $100 \%$ de precisão. Todas as formulações de lipossomas apresentaram um tamanho de diâmetro médio de $150 \mathrm{~nm}$. A determinação da $\mathrm{CE}_{50}$ em macrófagos infectados mostrou que as formulações de antimoniato de meglumina encapsulado em lipossomas foram entre 10 - 63 vezes mais eficazes do que a fármaco livre, indicando maior índice de seletividade. Por microscopia de fluorescência, foi verificada uma maior internalização de lipossomas fluorescentes em macrófagos infectados durante um curto tempo de incubação em comparação com macrófagos não infectados. A biodistribuição do antimoniato de meglumina irradiado encapsulado em lipossomas contendo fosfatidilserina mostrou que a formulação lipossomal promoveu um direcionamento seletivo do antimônio para tecidos do SMF, além do que manteve as doses elevadas nos órgãos por um período prolongado. Em conclusão, estes dados sugerem que o antimoniato de meglumina encapsulado em lipossomas apresentou maior eficácia do que a fármaco não lipossomal contra a infecção por Leishmania. O desenvolvimento de formulações lipossomais pode ser uma nova alternativa para a quimioterapia de doenças infecciosas, especialmente Leishmanioses, já que são usados como sistemas carreadores para entrega sustentada e direcionada de fármacos ao local da infecção.
\end{abstract}




\title{
DEVELOPMENT AND PHARMACOKINETIC OF ANTIMONY ENCAPSULATED IN LIPOSOMES OF PHOSPHATIDYLSERINE USING RADIOISOTOPES IN EXPERIMENTAL LEISHMANIASIS
}

\author{
Samanta Etel Treiger Borborema
}

\begin{abstract}
Leishmaniases are a complex of parasitic diseases caused by intramacrophage protozoa of the genus Leishmania, and is fatal if left untreated. Pentavalent antimonials, though toxic and their mechanism of action being unclear, remain the first-line drugs for treatment. Effective therapy could be achieved by delivering antileishmanial drugs to these sites of infection. Liposomes are phospholipid vesicles that promote improvement in the efficacy and action of drugs in target cell. Liposomes are taken up by the cells of mononuclear phagocytic system (MPS). The purpose of this study was to develop a preparation of meglumine antimoniate encapsulated in liposomes of phosphatidylserine and to study its pharmacokinetic in healthy mice to establish its metabolism and distribution. Quantitative analysis of antimony from liposomes demonstrated that Neutron Activation Analysis was the most sensitive technique with almost $100 \%$ of accuracy. All liposome formulations presented a mean diameter size of $150 \mathrm{~nm}$. The determination of $\mathrm{IC}_{50}$ in infected macrophage showed that liposome formulations were between $10-63$ fold more effective than the free drug, indicating higher selectivity index. By fluorescence microscopy, an increased uptake of fluorescent-liposomes was seen in infected macrophages during short times of incubation compared with non-infected macrophages. Biodistribution studies showed that meglumine antimoniate irradiated encapsulated in liposomes of phosphatidylserine promoted a targeting of antimony for MPS tissues and maintained high doses in organs for a prolonged period. In conclusion, these data suggest that meglumine antimoniate encapsulated in liposomes showed higher effectiveness than the non-liposomal drug against Leishmania infection. The development of liposome formulations should be a new alternative for the chemotherapy of infection diseases, especially Leishmaniasis, as they are used to sustain and target pharmaceuticals to the local of infection.
\end{abstract}




\section{SUMÁRIO}

\section{Página}

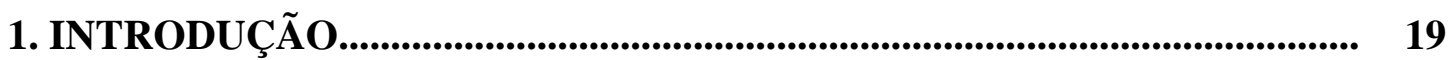

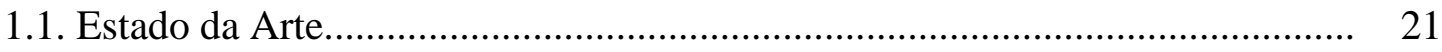

1.1.1. Leishmanioses................................................................................... 21

1.1.1.1. Formas clínicas................................................................................... 21

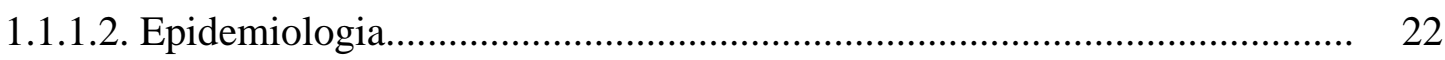

1.1.1.3. Agente etiológico............................................................................. 25

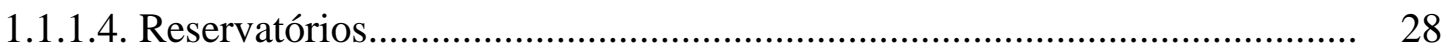

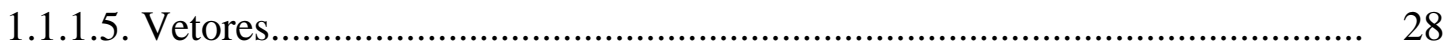

1.1.1.6. Período de incubação.............................................................................. 29

1.1.1.7. Ciclo Evolutivo.................................................................................. 29

1.1.1.8. Diagnóstico ....................................................................................... 30

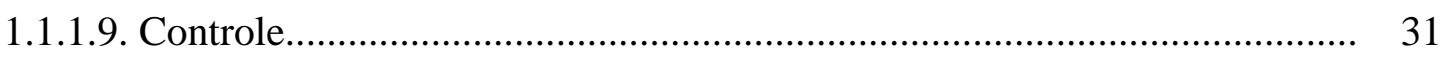

1.1.1.10. Tratamento ........................................................................................ 31

1.1.2. Novas Estratégias Terapêuticas.................................................................... 37

1.1.2.1. Macrófagos....................................................................................... 38

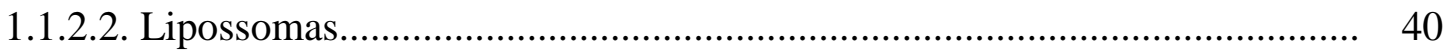

1.1.3. Estudos Farmacológicos de Antimonial Encapsulado em Lipossomas......... 46

1.1.3.1. Determinação de antimônio........................................................................ 47

1.1.3.2. Estudos farmacológicos com auxílio de um traçador radioativo................. $\quad 50$

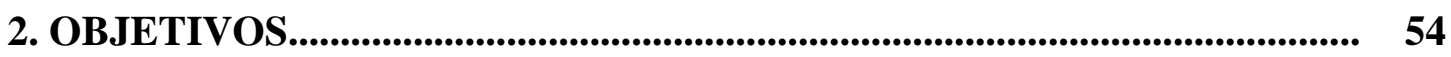

3. MATERIAIS E MÉTODOS...................................................................... 55

3.1. Solventes, Soluções, Fármacos................................................................... 55

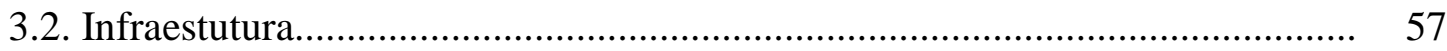

3.2.1. Equipamentos, Utensílios e Softwares........................................................ 58

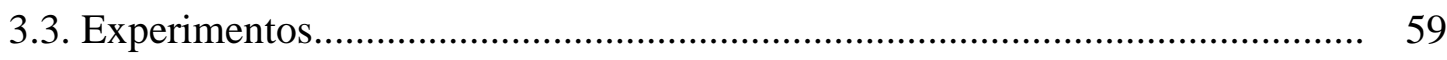

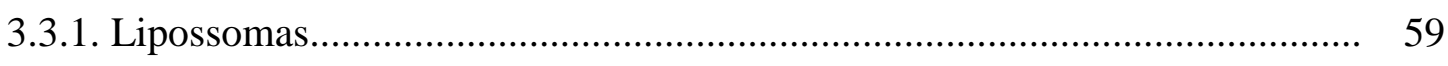

3.3.1.1. Preparação de diferentes formulações de antimônio lipossomal................. 59

3.3.1.1.1. Lipossomas por sonicação seguido de extrusão através de membrana 
de policarbonato (FEL). 59

3.3.1.1.2. Lipossomas pequenos vazios liofilizados (FDEL).

3.3.1.1.3. Lipossomas por congelamento-descongelamento seguido de extrusão através de membrana de policarbonato usando alta pressão (FTL). 61

3.3.1.2. Preparação de Lipossoma Marcado com Corante Fluorescente (Dil-FTL) 62

3.3.1.3. Preparação de Lipossoma Radiomarcado (FDEL-AMI)............................ 63

3.3.2. Caracterização dos Lipossomas.................................................................. 63

3.3.2.1. Quantificação de fosfolipídios.............................................................. 63

3.3.2.2. Determinação do tamanho dos lipossomas.............................................. 64

3.3.2.3. Determinação da eficiência de encapsulação (Ee).................................. 64

3.3.2.4. Determinação da estabilidade das formulações lipossomais...................... 64

3.3.3. Determinação de Antimônio Total............................................................... 65

3.3.3.1. Espectrofotometria UV-visível por leucocristal de violeta (LCV)........... 65

3.3.3.2. Voltametria de pulso diferencial (VPD) .................................................. 66

3.3.3.3. Espectrometria de emissão ótica com plasma acoplado indutivamente

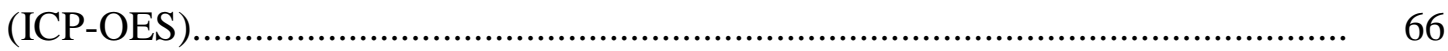

3.3.3.4. Análise por ativação neutrônica instrumental (AAN).............................. 67

3.3.3.5. Produção e análise do antimoniato de meglumina irradiado com

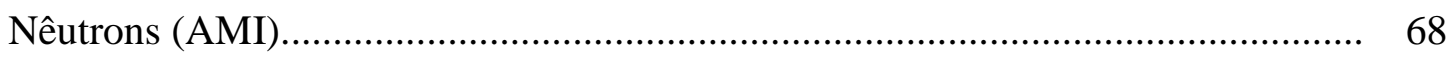

3.3.4. Estudos Biológicos................................................................................. $\quad 70$

3.3.4.1. Animais de laboratório................................................................................. $\quad 70$

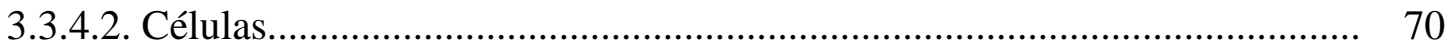

3.3.4.3. Determinação da Concentração Efetiva $50 \%\left(\mathrm{CE}_{50}\right)$ em promastigotas de L. (L.) chagasi.

3.3.4.4. Determinação da Concentração Efetiva $50 \%\left(\mathrm{CE}_{50}\right)$ em promastigotas de L. (L.) major.

3.3.4.5. Determinação da Concentração Efetiva $50 \%\left(\mathrm{CE}_{50}\right)$ em macrófago peritoneal infectado com Leishmania ................................................................. 73

3.3.4.6. Determinação da citotoxicidade............................................................... 73

3.3.4.7. Estudos de Interação Célula-Lipossoma.................................................. 74

3.3.4.7.1. Captação e internalização de lipossoma marcado com corante fluorescente por macrófago RAW 264.7 não infectado e infectado com $L$. (L.) major. 
3.3.4.7.2. Associação e captação de lipossoma marcado com corante fluorescente por macrófago RAW 264.7 não infectado e infectado com $L$. (L.) major usando

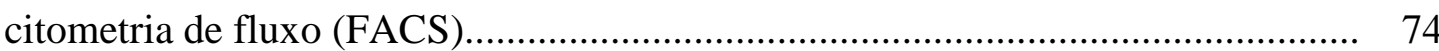

3.3.4.8. Estudos de biodistribuição do antimônio lipossomal (FDEL-AMI)........... 75

3.3.5. Análise Estatística..................................................................................... 76

4. RESULTADOS COMENTADOS....................................................................... 77

4.1. Determinação de Antimônio Total.................................................................... 77

4.1.1. Espectrofotometria UV-visível por leucocristal de violeta (LCV).............. 77

4.1.2. Voltametria de pulso diferencial (VPD) ...................................................... 79

4.1.3. Espectrometria de emissão ótica com plasma acoplado indutivamente

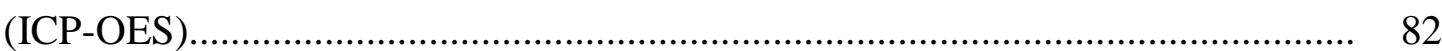

4.1.4. Análise por ativação neutrônica instrumental (AAN)................................. 84

4.1.5. Produção e análise do antimoniato de meglumina irradiado com Nêutrons (AMI) 85

4.2. Caracterização dos Lipossomas.................................................................... 89

4.2.1. Quantificação de fosfolipídios................................................................... 89

4.2.2. Determinação do tamanho dos lipossomas................................................. 90

4.2.3. Determinação da eficiência de encapsulação (Ee)....................................... 95

4.2.4. Determinação da estabilidade das formulações lipossomais.......................... 98

4.2.5. Lipossoma radiomarcado (FDEL-AMI)................................................... 100

4.3. Estudos Biológicos................................................................................ 101

4.3.1. Determinação da Concentração Efetiva $50 \%\left(\mathrm{CE}_{50}\right)$ em promastigotas de Leishmania

4.3.2. Determinação da Concentração Efetiva $50 \%\left(\mathrm{CE}_{50}\right)$ em macrófago peritoneal infectado com Leishmania.............................................................. 104

4.3.3. Determinação da citotoxicidade ................................................................. 108

4.3.4. Estudos de Interação Célula-Lipossoma..................................................... 110

4.3.4.1. Captação e internalização de lipossoma marcado com corante fluorescente por macrófago RAW 264.7 não infectado e infectado com $L$. (L.) major.

4.3.4.2. Associação e captação de lipossoma marcado com corante fluorescente por macrófago RAW 264.7 não infectado e infectado com $L$. (L.) major usando citometria de fluxo (FACS) 
4.3.5. Estudos de biodistribuição do antimônio lipossomal (FDEL-AMI)............. 120

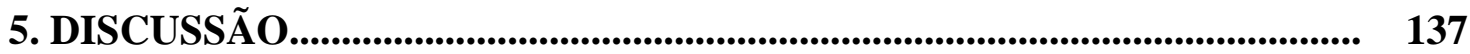

6. CONCLUSÕES.................................................................................................... 140

ANEXO A- Aprovação do Comitê de Ética em Pesquisa do IMTSP.............. 142

ANEXO B - Tabela de biodistribuição do FDEL-AMI e AMI......................... 143

REFERÊNCIAS BIBLIOGRÁFICAS............................................................... 153 


\section{LISTA DE TABELAS}

Página

01. Espécies de Leishmania causadoras de Leishmaniose Humana (Adaptado de Reithinger et al., 2007). LCL= Leishmaniose Cutânea Localizada; LMC= Leishmaniose Mucocutânea; LCD= Leishmaniose Cutânea Difusa; LV=

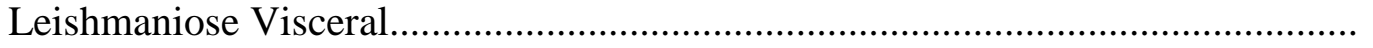

02. Estrutura química dos antimoniais trivalentes empregados na terapêutica das Leishmanioses (Rath et al., 2003).

03. Estrutura química dos antimoniais pentavalentes empregados na terapêutica das Leishmanioses (Rath et al., 2003).

04. Outros fármacos empregados na terapia das Leishmanioses (Rath et al.,2003) 36

05. Composição de lipídios e fármaco usados na preparação dos lipossomas FEL. 59

06. Composição de lipídios e fármaco usados na preparação dos lipossomas FDEL

07. Composição de lipídios e fármaco usados na preparação dos lipossomas FTL. 62

08. Composição de lipídios e fármaco usados na preparação dos lipossomas fluorescentes (Dil-FTL)

09. Parâmetros utilizados para determinação de antimônio por ICP-OES. 67

10. Determinação espectrofotométrica de antimônio usando leucocristal de violeta (LCV) média \pm desvio-padrão $(n=3)$.

11. Quantificação de antimônio em diferentes amostras por Voltametria de Pulso Diferencial (VPD).

12. Quantificação de antimônio em diferentes amostras por ICP-OES. Os dados são apresentados como a média \pm desvio padrão $(n=3)$

13. Quantificação de antimônio em diferentes amostras por Análise por Ativação Neutrônica Instrumental. Os dados são apresentados como a média \pm desvio padrão $(n=3)$.

14. Espectros de raios gama do ${ }^{122} \mathrm{Sb}$ e ${ }^{124} \mathrm{Sb}$, determinados por meio de espectroscopia- $\gamma$, utilizando um detector de Ge hiper puro

15. Determinação da concentração radioativa dos radioisótopos de $\mathrm{Sb}$ produzidos 
no Reator Nuclear IEA-R1m (IPEN/CNEN-SP). Os dados são apresentados como a média \pm desvio padrão $(n=4)$.

16. Avaliação do diâmetro médio do antimoniato de meglumina encapsulado em lipossomas (AM-FTL) após as diferentes etapas de preparação.

17. Avaliação do diâmetro médio de diferentes formulações de lipossomas (FTL) utilizando um determinador de tamanho de partículas por espalhamento de luz laser.

18. Avaliação da concentração inicial das soluções de fármaco usadas na preparação de lipossomas, da concentração final após separação do fármaco não encapsulado e da eficiência de encapsulação (Ee). Os dados são apresentados como a média \pm desvio padrão $(n=4)$ ou média $(n=1)$. n.d. = não determinado.......

19. Avaliação da Eficiência de Encapsulação (Ee) do antimoniato de meglumina irradiado encapsulado em lipossomas (FDEL-AMI). Os dados são apresentados como a média \pm desvio padrão $(n=4)$ ou média $(n=1)$

20. Avaliação da Concentração Efetiva $50 \%\left(\mathrm{CE}_{50}\right)$ de diferentes formulações lipossomais em promastigotas de $L$. (L.) major e $L$. (L.) chagasi. IC95\%= Intervalo de Confiança 95\%; $(n=3)$.

21. Avaliação da Concentração Efetiva $50 \%\left(\mathrm{CE}_{50}\right)$ de diferentes formulações lipossomais em macrófagos peritoneais infectados com amastigotas de $L$. (L.) major. IC95\%= Intervalo de Confiança 95\%; $(\mathrm{n}=3)$

22. Avaliação da Concentração Efetiva $50 \%\left(\mathrm{CE}_{50}\right)$ de diferentes formulações lipossomais em macrófagos peritoneais infectados com amastigotas de $L$. (L.) chagasi. IC95\%= Intervalo de Confiança 95\%; $(n=3)$.

23. Avaliação da citotoxicidade de diferentes formulações lipossomais em macrófagos peritoneais e células RAW 264.7. IC95\%= Intervalo de Confiança $95 \% ;$ n.d. = não determinado; $(\mathrm{n}=3)$.

24. Avaliação do Índice de Seletividade dos antimoniais livres e encapsulados em lipossomas.

25. Comparação da associação e ligação de lipossomas fluorescentes com macrófagos não infectados e infectados com $L$. (L.) major. Células incubadas com Dil-FTL (9,5 $\mu$ mol lipídios/poço e marcados com 0,1 $\mu$ mol de Dil) e analisadas pela contagem e medição das características fluorescentes de 10.000 células únicas em suspensão usando FACS. 


\section{LISTA DE FIGURAS}

01. Distribuição geográfica dos casos de Leishmaniose Visceral no mundo

(Chappuis et al., 2007).

02. Distribuição geográfica dos casos de Leishmaniose Cutânea no mundo

(Reithinger et al., 2007).

03. Distribuição geográfica dos casos de Leishmaniose Cutânea no mundo

(Reithinger et al., 2007).

04. Ciclo evolutivo das Leishmania sp. (OMS).

05. Características estruturais dos lipossomas (Frézard et al., 2005).....

06. Interação lipossoma-célula.

07. Representação esquemática da interação do nêutron com um núcleo alvo, reação tipo $(\mathrm{n}, \gamma)$.....

08. Esquema simplificado de decaimento do ${ }^{122} \mathrm{Sb}$. A: por emissão de $\beta^{-}$; B: por emissão de captura eletrônica (EC).

09. Esquema simplificado de decaimento do ${ }^{124} \mathrm{Sb}$, por emissão de $\beta^{\text {- }}$

10. Esquema do método de preparação de lipossomas do tipo FEL, baseado no processo de hidratação do filme lipídico

11. Esquema do método de preparação de lipossomas do tipo FDEL, baseado no processo de hidratação do filme lipídico......

12. Esquema do processo de redução e determinação do $\mathrm{Sb}(\mathrm{V})$.

13. Curva de calibração do antimônio por determinação espectrofotométrica usando leucocristal de violeta num comprimento de onda de $590 \mathrm{~nm}$.

14. Voltamograma característico do antimônio por Voltametria de Pulso

Diferencial (A). Curvas: 1: Solução de $\mathrm{Sb}(\mathrm{V}) ; 2,3$ e 4: Adição de padrão;

Método de adição de padrão (B)

15. Curva de calibração do antimônio por ICP-OES.

16. Análise dos radioisótopos de antimônio produzidos no Reator Nuclear IEA-

R1m (IPEN/CNEN-SP). A e C = fluxo de nêutrons térmicos de $1,0 \times 10^{12} \mathrm{n} / \mathrm{cm}^{2} \mathrm{~s}$;

$\mathrm{B}$ e $\mathrm{D}=$ fluxo de nêutrons térmicos de $1,1 \times 10^{13} \mathrm{n} / \mathrm{cm}^{2} \mathrm{~s}$.

17. Curva de calibração da fosfatidilcolina por espectrofotometria usando 
ferrotiocianato de amônio num comprimento de onda de $485 \mathrm{~nm}$

18. Micrografia de lipossomas por microscopia eletrônica de transmissão usando a técnica de coloração negativa. $\mathrm{A}$ = antimoniato de meglumina encapsulado em lipossoma liofilizado vazio (AM-FDEL); $\mathrm{B}=$ antimoniato de meglumina encapsulado em lipossoma por extrusão através de membrana de policarbonato (AM-FEL). As setas indicam as vesículas multilamelares (MLV)

19. Avaliação do diâmetro médio de diferentes formulações de lipossomas por microscopia eletrônica de transmissão usando a técnica de coloração negativa. AM-FDEL = antimoniato de meglumina encapsulado em lipossoma liofilizado vazio; $\mathrm{AM-FEL} \mathrm{=} \mathrm{antimoniato} \mathrm{de} \mathrm{meglumina} \mathrm{encapsulado} \mathrm{em} \mathrm{lipossoma} \mathrm{por}$ extrusão através de membrana de policarbonato.

20. Avaliação da eficiência de encapsulação (Ee). Os dados são apresentados como a média \pm desvio padrão $(n=4)$.

21. Avaliação da estabilidade in vitro das formulações de lipossomas. $A=A M-$ FDEL = antimoniato de meglumina encapsulado em lipossoma liofilizado vazio; $\mathrm{B}=\mathrm{AM}-\mathrm{FEL}=$ antimoniato de meglumina encapsulado em lipossoma por extrusão através de membrana de policarbonato.

22. Imagens microscópicas de macrófagos peritoneais infectados com amastigotas de L. (L.) major, observadas sob óleo de imersão (100x) num microscópio óptico. (A) controle, células não tratadas (macrófagos infectados com amastigotas); (B) macrófagos após tratamento com $3,8 \mu \mathrm{g} / \mathrm{mL}$ de antimoniato de meglumina (macrófagos infectados com amastigotas); (C) macrófagos após tratamento com 1,6 $\mu \mathrm{g} / \mathrm{mL}$ de AM-PS-FTL (macrófago livre de parasitos); (D) macrófagos após tratamento com 1,6 $\mu \mathrm{g} / \mathrm{mL}$ de AM-FTL (macrófago livre de parasitos).

23. Curva dose-resposta da determinação da Concentração Efetiva $50 \%\left(\mathrm{CE}_{50}\right)$ de diferentes formulações lipossomais em macrófagos peritoneais infectados com amastigotas de $L$. (L.) chagasi.

24. Comparação da captação de lipossomas fluorescentes por macrófagos não infectados e infectados com $L$. (L.) major em diferentes períodos de tempo $(1,83$ $\mu$ mol lipídios/poço e marcados com 0,02 $\mu$ mol de Dil). A) macrófagos incubados com Dil-FTL; B) macrófagos incubados com Dil-PS-FTL. Os dados são apresentados como a média \pm desvio padrão $(n=2)$. 
25. Imagens por microscopia de fluorescência de macrófagos infectados com $L$. (L.) major. Células incubadas com lipossomas fluorescentes (vermelho). Corante DAPI adicionado como um marcador de DNA, núcleos (azul)

26. Comparação da captação de lipossomas fluorescentes por macrófagos infectados com L. (L.) major em diferentes períodos de tempo $(1,83 \mu \mathrm{mol}$ lipídios/poço e marcados com 0,02 $\mu$ mol de Dil). Os dados são apresentados como a média \pm desvio padrão $(n=2)$.

27. Imagens por microscopia de fluorescência de macrófagos não infectados e infectados com L. (L.) major. As células foram incubadas com lipossomas fluorescentes (vermelho) durante $1 \mathrm{~h}$ (1,83 $\mu \mathrm{mol}$ lipídios/poço e marcados com $0,02 \mu \mathrm{mol}$ de Dil). O corante DAPI foi adicionado como um marcador de DNA, núcleos (azul). A) macrófagos infectados e incubados com Dil-FTL; B) macrófagos não infectados e incubados com Dil-FTL; C) macrófagos infectados e incubados com Dil-PS-FTL; D) macrófagos não infectados e incubados com Dil-PS-FTL (60X)

28. Imagens por microscopia de fluorescência de macrófagos infectados com $L$. (L.) major. As células foram incubadas com lipossomas fluorescentes (vermelho) durante $18 \mathrm{~h}$ (1,83 $\mu$ mol lipídios/poço e marcados com 0,02 $\mu$ mol de Dil). O corante DAPI foi adicionado como um marcador de DNA, núcleos (azul). (100x). As setas brancas indicam as áreas com alta concentração de amastigotas.

29. Comparação da associação e ligação de lipossomas fluorescentes com macrófagos não infectados e infectados com $L$. (L.) major. As células foram incubadas com Dil-FTL (9,5 $\mu$ mol lipídios/poço e marcados com 0,1 $\mu \mathrm{mol}$ de Dil) e analisadas pela contagem e medição das características fluorescentes de 10.000 células únicas em suspensão usando FACS.

30. Comparação da associação e ligação de lipossomas fluorescentes com macrófagos não infectados e infectados com $L$. (L.) major. Células foram incubadas com Dil-FTL (9,5 $\mu$ mol lipídios/poço e marcados com 0,1 $\mu \mathrm{mol}$ de Dil) e analisadas pela contagem e medição das características fluorescentes de 10.000 células únicas em suspensão usando FACS. Porcentagens de fluorescência em R1.

31. Biodistribuição do antimônio em camundongos sadios, após a injeção intraperitoneal das formulações de antimoniato de meglumina irradiado 
encapsulado em lipossomas (FDEL-AMI) e antimoniato de meglumina irradiado livre (AMI). (A) cérebro; (B) coração; (C) pulmão; (D) útero/ovários. Os dados são indicados como média \pm desvio padrão $(n=5)$. $\star=$ diferença estatisticamente significante entre as formulações $(\mathrm{P}<0,05)$

32. Biodistribuição do antimônio na musculatura esquelética de camundongos sadios, após a injeção intraperitoneal das formulações de antimoniato de meglumina irradiado encapsulado em lipossomas (FDEL-AMI) e antimoniato de meglumina irradiado livre (AMI). Os dados são indicados como média \pm desvio padrão $(n=5) . \star=$ diferença estatisticamente significante entre as formulações $(\mathrm{P}<0,05)$.

33. Biodistribuição do antimônio no baço de camundongos sadios, após a injeção intraperitoneal das formulações de antimoniato de meglumina irradiado encapsulado em lipossomas (FDEL-AMI) e antimoniato de meglumina irradiado livre (AMI). Os dados são indicados como média \pm desvio padrão $(\mathrm{n}=5)$. $\star=$ diferença estatisticamente significante entre as formulações $(\mathrm{P}<0,05)$.

34. Biodistribuição do antimônio no fígado de camundongos sadios, após a injeção intraperitoneal das formulações de antimoniato de meglumina irradiado encapsulado em lipossomas (FDEL-AMI) e antimoniato de meglumina irradiado livre (AMI). Os dados são indicados como média \pm desvio padrão $(n=5) . \star=$ diferença estatisticamente significante entre as formulações $(\mathrm{P}<0,05)$.

35. Biodistribuição do antimônio em camundongos sadios, após a injeção intraperitoneal das formulações de antimoniato de meglumina irradiado encapsulado em lipossomas (FDEL-AMI) e antimoniato de meglumina irradiado livre (AMI). (A) estômago; (B) intestino delgado; (C) intestino grosso; (D) rins. Os dados são indicados como média \pm desvio padrão $(n=5)$. $\star=$ diferença estatisticamente significante entre as formulações $(\mathrm{P}<0,05)$...

36. Farmacocinética do antimônio em camundongos sadios, após a injeção intraperitoneal da formulação de: (A) antimoniato de meglumina irradiado encapsulado em lipossomas (FDEL-AMI); (B) antimoniato de meglumina irradiado livre. Os dados são indicados como média \pm desvio padrão $(n=5) \ldots \ldots \ldots$ 37. Farmacocinética do antimônio no sangue de camundongos sadios, após a injeção intraperitoneal das formulações de antimoniato de meglumina irradiado encapsulado em lipossomas (FDEL-AMI) e antimoniato de meglumina irradiado 
livre (AMI). Os dados são indicados como média \pm desvio padrão $(\mathrm{n}=5)$. $\star=$ diferença estatisticamente significante entre as formulações $(\mathrm{P}<0,05)$.

38. Biodistribuição do antimônio em camundongos sadios, após a injeção intraperitoneal das formulações de antimoniato de meglumina irradiado encapsulado em lipossomas (FDEL-AMI) e antimoniato de meglumina irradiado livre (AMI). (A) fígado; (B) baço; (C) estômago; (D) intestino delgado; (E) intestino grosso; (F) rins. Os dados são indicados como média \pm desvio padrão (n $=5) . \star=$ diferença estatisticamente significante entre as formulações $(\mathrm{P}<0,05) \ldots$.

39. Farmacocinética do antimônio no sangue de camundongos sadios, após a injeção intraperitoneal das formulações de antimoniato de meglumina irradiado encapsulado em lipossomas (FDEL-AMI) e antimoniato de meglumina irradiado livre (AMI). Os dados são indicados como média \pm desvio padrão $(\mathrm{n}=5)$. $\star=$ diferença estatisticamente significante entre as formulações $(\mathrm{P}<0,05)$ 


\section{LISTA DE ABREVIATURAS E SIGLAS}

AAN: Análise por Ativação Neutrônica

AM: Antimoniato de Meglumina (Glucantime®)

$\star$ AM-FDEL: Antimoniato de meglumina encapsulado em lipossomas pequenos vazios liofilizados

^ AM-FEL: Antimoniato de meglumina encapsulado em lipossomas por sonicação seguido de extrusão através de membrana de policarbonato

AM-FTL: Antimoniato de meglumina encapsulado em lipossomas por congelamentodescongelamento, seguido de extrusão através de membrana de policarbonato usando alta pressão

$\star$ AMI: Antimoniato de Meglumina Irradiado

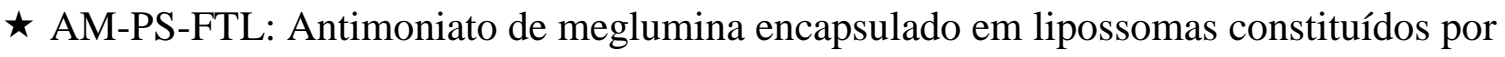
fosfatidilserina, produzidos por congelamento-descongelamento, seguido de extrusão através de membrana de policarbonato usando alta pressão

$\star \mathrm{CE}_{50}$ : Concentração Efetiva $50 \%$

$\star$ Dil: Corante Fluorescente

$\star$ Dil-AM-FTL: Antimoniato de meglumina encapsulado em lipossomas por congelamento-descongelamento, seguido de extrusão através de membrana de policarbonato usando alta pressão, marcado com corante fluorescente

$\star$ Dil-FTL: Lipossomas por congelamento-descongelamento, seguido de extrusão através de membrana de policarbonato usando alta pressão, marcado com corante fluorescente

$\star$ Dil-PS-FTL: Lipossomas constituídos por fosfatidilserina, produzidos por congelamento-descongelamento, seguido de extrusão através de membrana de policarbonato usando alta pressão, marcado com corante fluorescente

$\star$ Ee: Eficiência de encapsulação (\%)

$\star$ FDEL: Lipossomas pequenos vazios liofilizados (Freeze-Dried Empty Liposome)

$\star$ FDEL-AMI: Antimoniato de meglumina irradiado encapsulado em lipossomas pequenos vazios liofilizados

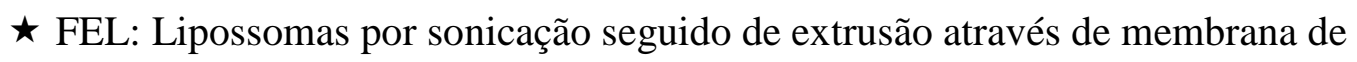
policarbonato (Filter Extrusion Liposome) 
$\star$ FTL: lipossomas por congelamento-descongelamento, seguido de extrusão através de membrana de policarbonato usando alta pressão (Freeze-Thawed Liposome)

$\star$ IC $95 \%$ : Intervalo de Confiança $95 \%$

$\star$ ICP-OES: Espectrometria de Emissão Ótica com Plasma Acoplado Indutivamente

$\star$ IS: Índice de Seletividade

$\star$ LC: Leishmaniose Cutânea

$\star$ LCD: Leishmaniose Cutânea Difusa

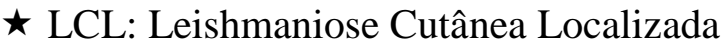

$\star$ LCV: Leucocristal de Violeta

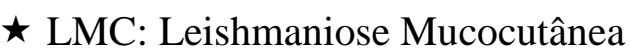

$\star$ LTA: Leishmaniose Tegumentar Americana

$\star$ LV: Leishmaniose Visceral

$\star$ LVA: Leishmaniose Visceral Americana

$\star$ NMG: N-metilglucamina

$\star$ VPD: Voltametria de Pulso Diferencial

$\star$ PS-FTL: Lipossomas constituídos por fosfatidilserina, produzidos por congelamentodescongelamento, seguido de extrusão através de membrana de policarbonato usando alta pressão

$\star \mathrm{Sb}(\mathrm{III})$ : solução de sal de Antimônio Trivalente

$\star \mathrm{Sb}$ (III): solução de sal de antimônio trivalente encapsulada em lipossomas por congelamento-descongelamento, seguido de extrusão através de membrana de policarbonato usando alta pressão

$\star$ Sb(III)-FDEL: solução de sal de antimônio trivalente encapsulada em lipossomas pequenos vazios liofilizados

$\star \mathrm{Sb}(\mathrm{V})$ : solução de sal de Antimônio Pentavalente

$\star \mathrm{Sb}(\mathrm{V})$-FEL: solução de sal de antimônio pentavalente encapsulada em lipossomas por sonicação seguido de extrusão através de membrana de policarbonato

$\star$ SMF: Sistema Mononuclear Fagocitário 


\section{INTRODUÇÃO}

As Leishmanioses são um complexo de doenças infecciosas antropozoonóticas, causadas por protozoários do gênero Leishmania e transmitidas por flebotomíneos. A Leishmaniose Humana é distribuída por todo o mundo, mas principalmente nas regiões tropicais e subtropicais, com incidência de 12 milhões de casos ao ano, ocasionando um espectro de doenças que provocam desde lesão cutânea única e simples com cura espontânea até formas viscerais fatais (Chappuis et al., 2007). A maior incidência de Leishmaniose Visceral (LV) no mundo e a co-infecção com HIV a tornaram uma prioridade da Organização Mundial de Saúde (Guerin et al., 2002).

O regime terapêutico de primeira escolha para o tratamento das Leishmanioses é baseado na utilização dos antimoniais pentavalentes, como o antimoniato de meglumina (Glucantime ${ }^{\circledR}$ ) e o estibogluconato de sódio (Pentostam ${ }^{\circledR}$ ). Estes foram introduzidos pela primeira vez em 1945 e permanecem sendo utilizados como tratamentos eficazes para as Leishmanioses. Porém, a necessidade de 28 dias de administração parenteral, a presença de efeitos colaterais severos, a eficácia variável contra as diversas manifestações das Leishmanioses e o aparecimento de resistência são os fatores que limitam o uso destes medicamentos. Além disso, os medicamentos disponíveis para o tratamento das Leishmanioses são restritos, alguns como: deoxicolato de anfotericina $\mathrm{B}$, formulações lipídicas de anfotericina B, miltefosina e paromomicina, têm limitações em termos de toxicidade, eficácia variável, preços e esquemas de tratamentos inconvenientes. Cabe ressaltar que não existe vacina contra esta doença (Santos et al., 2008).

A alta prevalência das Leishmanioses, a inviabilidade econômica da utilização de fármacos alternativos, o número crescente de casos de co-infecção LV/HIV e a resistência às fármacos convencionais demonstram a necessidade de desenvolvimento de novos tratamentos mais eficientes e menos tóxicos. Porém, concomitantemente à busca de novos tratamentos, procura-se entender melhor e melhorar tanto a cinética quanto a especificidade dos fármacos já utilizados, e assim reduzir seus efeitos colaterais mais sérios.

Conforme recomendação da Organização Mundial de Saúde, através de sua agência internacional TDR ("Special Programme for Research and Training in Tropical Diseases"), estratégias para o desenvolvimento de novos medicamentos envolvem o 
planejamento/síntese de novas substâncias ativas ou de fármacos já conhecidos com modificações químicas; outra estratégia envolve a associação reversível do fármaco, já em uso, a um sistema transportador, a fim de direcioná-lo ao local alvo, reduzindo sua toxicidade e efeitos colaterais. Esta última estratégia, além de prolongar a validade de proteção por patente no uso do fármaco, oferece vantagens na fase de desenvolvimento, por utilizar um medicamento já caracterizado farmacologicamente. Entre os sistemas transportadores de medicamentos disponíveis, os lipossomas apresentam-se bastante promissores na terapia antileishmania (Frézard et al., 2005).

A utilização de um sistema lipossomal para carrear fármacos é uma ferramenta relativamente recente e que tem apresentado excelentes resultados na terapia antimonial (Tempone et al., 2004; Schettini et al., 2006). Considera-se extremamente viável o estudo de novas formulações de antimônio lipossomal, contendo fosfolipídios captados preferencialmente pelo sistema mononuclear fagocitário (SMF), pelo que se acredita que o melhoramento do uso dos antimoniais possa ser uma estratégia eficaz na terapêutica das Leishmanioses. Para se estudar o comportamento in vitro e in vivo destas formulações, propôs-se neste trabalho a radiomarcação das formulações lipossomais, devido às características favoráveis que o método de marcação com radioisótopos proporciona para os estudos investigativos. Uma averiguação nas fontes de buscas utilizadas no meio científico mostrou ausência de registros na literatura propondo a utilização de formulações de antimônio lipossomal constituídas por fosfolipídios com maior afinidade aos macrófagos e, radiomarcadas para a avaliação de seu comportamento in vivo. Este estudo, além de apresentar resultados diretos para o tratamento das Leishmanioses, com a marcação de lipossomas com radionuclídeos, apresenta um grande potencial como sistema radiofarmacológico para avaliação de vários tipos de lipossomas com diferentes composições lipídicas, apresentando avanços na terapia radionuclídica e no diagnóstico por imagem. 


\subsection{ESTADO DA ARTE}

\subsubsection{Leishmanioses}

As Leishmanioses são um complexo de doenças infecciosas antropozoonóticas causadas por várias espécies de protozoários parasitos Leishmania, consideradas um grande problema de saúde pública, representam um conjunto de doenças com importante espectro clínico e diversidade epidemiológica.

\subsubsection{Formas Clínicas}

A multiplicidade de espécies de Leishmania, vetores e reservatórios vertebrados em diferentes ambientes geográficos propicia a existência de distintas apresentações clínicas das Leishmanioses, as quais apresentam diferentes imunopatologias e graus de morbidade e mortalidade. As alterações no organismo, sequenciais à presença do parasito, dependem do binômio infectividade e antigenicidade de Leishmania e da imunidade e resistência já existentes ou desenvolvidas pelo hospedeiro após a infecção. Em decorrência dessa interação parasito-hospedeiro, o espectro clínico das Leishmanioses é variável.

Classicamente a doença se manifesta sob três diferentes formas clínicas:

Leishmaniose Cutânea (LC): é a forma mais comum da doença, as lesões de pele podem caracterizar a forma localizada (única ou múltipla), a forma disseminada (lesões muito numerosas em várias áreas do corpo) e a forma difusa. Na maioria das vezes a doença apresenta-se como uma lesão ulcerada única (Herwaldt, 1999). Em geral, as úlceras são indolores. As formas localizadas e disseminadas costumam responder bem à terapêutica tradicional. Na forma difusa, rara, as lesões são papulosas ou nodulares, deformantes e muito graves, distribuindo-se amplamente na superfície corporal. Evolui mal por não responder adequadamente à terapêutica (Helpburn, 2003).

Caso não tratadas, as lesões tendem à cura espontânea em período de alguns meses a poucos anos, podendo também permanecer ativas por vários anos e coexistir com lesões mucosas de surgimento posterior. As lesões cutâneas, ao evoluir para a cura, costumam deixar cicatrizes deformantes.

Leishmaniose Mucosa ou Mucocutânea (LMC): se expressa por lesões destrutivas localizadas nas mucosas das vias aéreas superiores. A forma clássica de LMC é 
secundária à lesão cutânea. Acredita-se que a lesão mucosa metastática ocorra por disseminação hematogênica ou linfática. Geralmente surge após a cura clínica da LC, com início insidioso e pouca sintomatologia. São mais frequentemente acometidas as cavidades nasais, seguidas da faringe, laringe e cavidade oral. Portanto, as queixas mais comuns no acometimento nasal são obstruções, epistaxes, rinorréia e crostas; da faringe, odinofagia; da laringe, rouquidão e tosse; da cavidade oral, ferida na boca. Poderá ocorrer destruição parcial ou total da pirâmide nasal e outras estruturas acometidas na boca (Balaña-Fouce et al., 1998). Mais raramente, podem também ser atingidas as conjuntivas oculares e mucosas de órgãos genitais e ânus.

A LCM apresenta-se sob as seguintes formas clínicas: forma mucosa tardia; forma mucosa de origem indeterminada; forma mucosa concomitante; forma mucosa contígua; forma mucosa primária (Brasil/MS/SVS, 2007).

Leishmaniose Visceral (LV): é o mais grave de todos os tipos de leishmanioses sendo freqüentemente fatal quando não é tratada; atualmente está diretamente associada com doenças imunossupressoras, como a AIDS, aparecendo assim como uma doença oportunista. A forma clássica é a doença plenamente manifesta. As manifestações clínicas são bastante exacerbadas, caracterizadas por hepatoesplenomegalia volumosa, febre e comprometimento do estado geral, perda de peso progressiva, anorexia e astenia. As alterações laboratoriais mais proeminentes são: anemia, leucopenia e/ou plaquetopenia e hipergamaglobulinemia (Brasil/MS/SVS, 2006).

\subsubsection{Epidemiologia}

A Leishmaniose Humana é distribuída em todo o mundo, ocorrendo em 88 países, principalmente nos trópicos e subtrópicos, com uma prevalência de 12 milhões de casos e uma incidência aproximada de 500.000 casos de LV e 1,5 milhões de casos de LC. Globalmente, há uma estimativa anual de 70.000 mortes e 350 milhões de pessoas expostas ao risco de infecção e doença (OMS, 2010). A morbidade e mortalidade por causa das leishmanioses causam cerca de 2,4 milhões de anos de vida perdidos por incapacidade (OMS, 2010).

A maioria dos casos de Leishmanioses concentra-se em apenas algumas regiões do mundo. Mais de $90 \%$ de todos os casos de LV ocorrem somente em seis países: Bangladesh, Índia, Nepal, Sudão, Etiópia e Brasil (FIG. 01). Mais de $90 \%$ dos casos de 
LC e LMC ocorrem somente em oito países: Afeganistão, Algéria, Brasil, Paquistão, Peru, Bolívia, Arábia Saudita e Síria (FIG. 02).

Tradicionalmente, a LV atinge comunidades pobres, em áreas rurais, sendo endêmica em países denominados subdesenvolvidos e em desenvolvimento, como a Índia, Nepal e Bangladesh que abrigam $67 \%$ da carga global da doença no mundo (Chappuis et al., 2007). A migração, a falta de medidas de controle e a co-infecção HIV-LV são os três principais fatores responsáveis pelo aumento da incidência de LV. Além disso, o perfil epidemiológico tem sofrido alterações e a transmissão da doença vem ocorrendo na interface de áreas urbanas e rurais entre pessoas de todas as idades e diferente sexo.

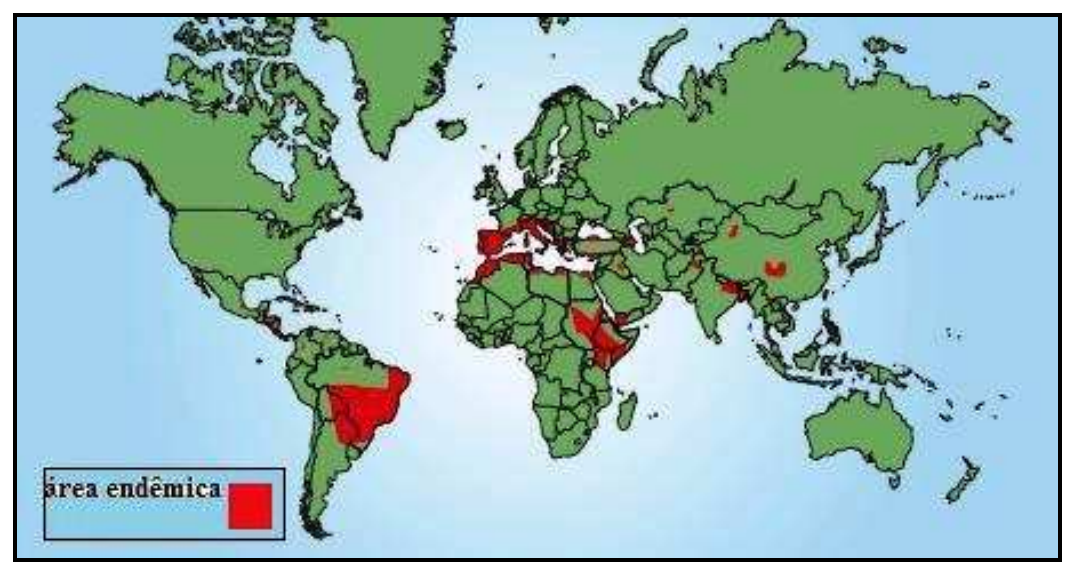

FIGURA 01 - Distribuição geográfica dos casos de Leishmaniose Visceral no mundo (Chappuis et al., 2007).

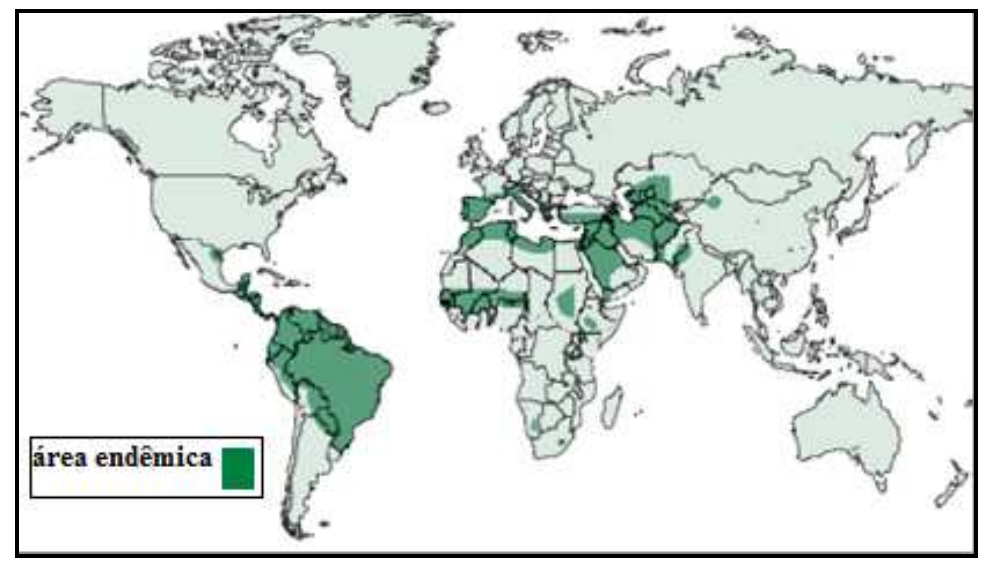

FIGURA 02 - Distribuição geográfica dos casos de Leishmaniose Cutânea no mundo (Reithinger et al., 2007).

As transformações do ambiente, provocadas pelo intenso processo migratório, por pressões econômicas ou sociais; a pauperização, consequente de distorções na 
distribuição de renda; o processo de urbanização crescente; o esvaziamento rural e as secas periódicas acarretam a expansão das áreas endêmicas e o aparecimento de novos focos da doença. Este fenômeno leva a uma redução do espaço ecológico da doença, facilitando a ocorrência de epidemias.

No Brasil, a Leishmaniose Visceral Americana (LVA) é uma doença endêmica, no entanto têm sido registrados surtos freqüentes. Inicialmente, sua ocorrência estava limitada a áreas rurais e a pequenas localidades urbanas, mas, hoje, encontra-se em franca expansão para grandes centros. A LVA está distribuída em 21 unidades da federação, atingindo as cinco regiões brasileiras. Entre 1999 e 2008 verificou-se que a média anual de casos de LVA foi de 3.379 casos e a incidência de 1,9 casos por 100.000 habitantes. A letalidade aumentou de 3,4 \%, em 1994, para 5,5\%, em 2008, o que representou um incremento de $61,8 \%$. A letalidade média entre 2005 e 2008 foi de 6,3\% (Brasil/MS/SVS, 2009).

A ampliação da área de distribuição geográfica da AIDS e sua extensão para camadas mais pobres da população e, por outro lado, a crescente urbanização da LVA faz supor que a prevalência de casos de co-infecção LVA/HIV venha aumentar nos próximos anos. No Brasil está descrita a maioria dos casos de co-infecção de LVA/HIV, onde a incidência de AIDS tem aumentado de 0,8 casos para cada 100.000 habitantes em 1986, para 10,5 casos para cada 100.000 habitantes em 1997 (Paredes et al., 2003). De acordo com os dados do Centro de Vigilância Epidemiológica, no Estado de São Paulo, do ano de 1999 até 05 de outubro de 2009, foram registrados 1.539 casos de LVA, resultando em 134 óbitos. Também foram notificados 7.383 casos de Leishmaniose Tegumentar Americana (LTA), do período de 1998 até 14 de dezembro de 2009 (CVE, 2010).

A partir da década de 80, no Brasil, verificou-se aumento no número de casos registrados de LTA, variando de 3.000 (1980) a 35.748 (1995). Observaram-se picos de transmissão a cada cinco anos, apresentando tendência de aumento do número de casos, a partir do ano de 1985, quando se solidificou a implantação das ações de vigilância e controle da LTA no país. No período de 1985 a 2005, verificaram-se uma média anual de 28.568 casos autóctones registrados e coeficiente de detecção médio de 18,5 casos/100.000 habitantes, verificando-se coeficientes mais elevados nos anos de 1994 e 1995, quando atingiram níveis de 22,83 e 22,94 casos por 100.000 habitantes, respectivamente (Brasil/MS/SVS, 2007). 


\subsubsection{Agente Etiológico}

Os agentes etiológicos das Leishmanioses são protozoários tripanosomatídeos do gênero Leishmania, parasito intracelular obrigatório sob forma aflagelada ou amastigota das células do sistema fagocítico mononuclear, com 2 - 4 mm de diâmetro (FIG. 03). Dentro do tubo digestivo do vetor, as formas amastigotas se diferenciam em promastigotas (flageladas), de 15 - $20 \mathrm{~mm}$ X 1,5-3,5 mm com 15-28 mm de flagelo (FIG. 03).
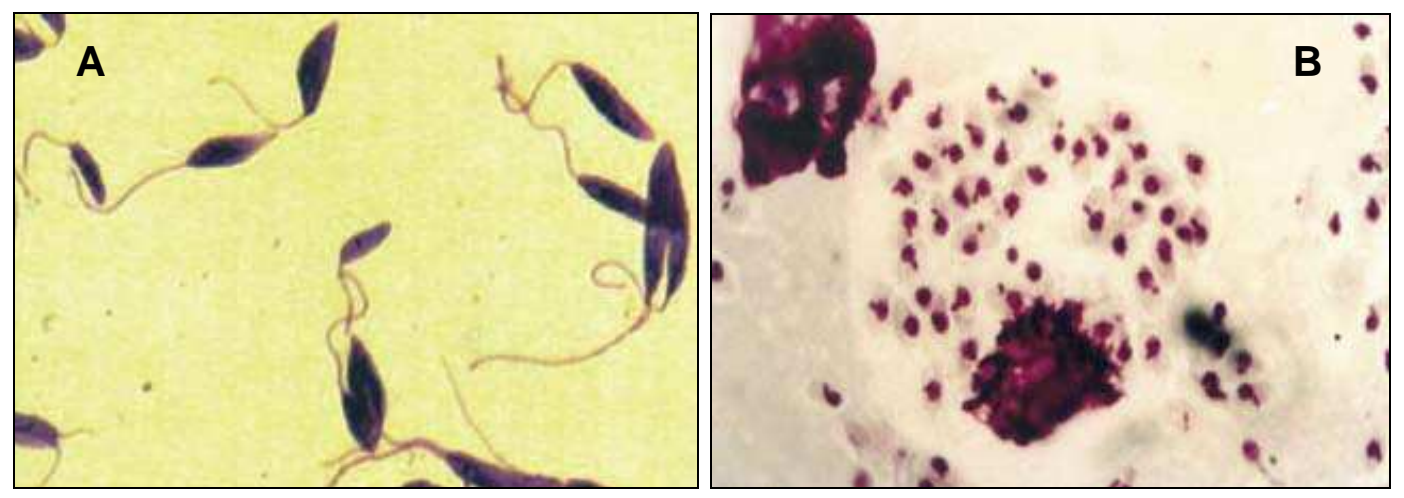

FIGURA 03 - Imagens por microscopia óptica de Leishmania sp. A= Forma flagelada ou promastigota; $\mathrm{B}=$ Forma aflagelada ou amastigota (Brasil, SVS/MS, 2006).

O esquema de classificação das Leishmania sp. é apresentado a seguir:

Reino - Protista

Subreino - Protozoa

Filo - Sarcomastigophora

Subfilo - Mastigophora

Classe - Zoomastigophora

Ordem - Kinetoplastida

Subordem - Tripanosomatina

Família - Trypanosomatidae

Gêneros - Leishmania

Subgêneros - Leishmania e Viannia

Espécies - Leishmania spp.

A classificação do gênero Leishmania em diferentes espécies baseou-se inicialmente nos aspectos clínicos, comportamento do vetor e distribuição geográfica (Magill, 2000). Porém, critérios moleculares, adotados recentemente, fizeram com que o 
gênero fosse subdividido em dois subgêneros: o subgênero Viannia que é encontrado somente no Novo Mundo e o subgênero Leishmania, que inclui espécies patogênicas do Velho Mundo e do Novo Mundo (Brito et al., 1998). Existem mais de 20 espécies de Leishmania patogênicas (TAB. 01), responsáveis pelas várias formas clínicas da doença (Guerin et al., 2002). 
TABELA 01 - Espécies de Leishmania causadoras de Leishmaniose Humana (Adaptado de Reithinger et al., 2007). LCL= Leishmaniose Cutânea Localizada; LMC = Leishmaniose Mucocutânea; LCD= Leishmaniose Cutânea Difusa; $\mathrm{LV}=$ Leishmaniose Visceral.

\begin{tabular}{|c|c|c|c|}
\hline Espécie & $\begin{array}{l}\text { Manifestação } \\
\text { clínica }\end{array}$ & $\begin{array}{c}\text { Ciclo de } \\
\text { transmissão }\end{array}$ & $\begin{array}{c}\text { Principal distribuição } \\
\text { geográfica }\end{array}$ \\
\hline \multicolumn{4}{|c|}{ Novo Mundo } \\
\hline L (Viannia) braziliensis & LCL, LMC & Zoonótico & $\begin{array}{c}\text { América do Sul, parte } \\
\text { América do Norte, México }\end{array}$ \\
\hline L(Viannia) panamensis & LCL, LMC & Zoonótico & $\begin{array}{c}\text { Nordeste da América do Sul } \\
\text { e sudeste da América } \\
\text { Central }\end{array}$ \\
\hline$L($ Viannia $)$ peruviana & LCL & Zoonótico & Peru \\
\hline L(Viannia) guyanensis & LCL & Zoonótico & América do Sul \\
\hline$L$ (Viannia) lainsoni & LCL & Zoonótico & América do Sul \\
\hline L (Viannia) colombiensis & LCL & Zoonótico & Nordeste da América do Sul \\
\hline L (Leishmania) amazonensis & LCL, LCD & Zoonótico & América do Sul \\
\hline$L$ (Leishmania) mexicana & LCL, LCD & Zoonótico & $\begin{array}{c}\text { America Central, México e } \\
\text { EUA }\end{array}$ \\
\hline$L$ (Leishmania) pifanoi & LCL & Zoonótico & América do Sul \\
\hline L(Leishmania)venezuelensis & LCL & Zoonótico & Norte da América do Sul \\
\hline L (Leishmania) garnhami & LCL & Zoonótico & América do Sul \\
\hline$L$ (Leishmania) chagasi & LV & Zoonótico & América Latina \\
\hline \multicolumn{4}{|c|}{ Velho Mundo } \\
\hline L (Leishmania) aethiopica & LCL, LCD & Zoonótico & Etiópia, Quênia \\
\hline L(Leishmania) killicki & LCL & Zoonótico & África do Norte \\
\hline$L($ Leishmania $)$ major & LCL & Zoonótico & $\begin{array}{c}\text { Ásia Central, África do } \\
\text { Norte, Oriente Médio, Leste } \\
\text { da África }\end{array}$ \\
\hline$L$ (Leishmania) tropica & LCL & Antroponótico & $\begin{array}{l}\text { Ásia Central, Oriente } \\
\text { Médio, partes da África do } \\
\text { Norte e sudoeste da Ásia }\end{array}$ \\
\hline$L$ (Leishmania) donovani & LV, LCL & Antroponótico & $\begin{array}{l}\text { África, Ásia Central, } \\
\text { sudoeste da Ásia }\end{array}$ \\
\hline \multicolumn{4}{|c|}{ Velho e Novo Mundo } \\
\hline$L$ (Leishmania) infantum & LV, LCL & Zoonótico & $\begin{array}{c}\text { Europa, África do Norte, } \\
\text { América Central e América } \\
\text { do Sul }\end{array}$ \\
\hline
\end{tabular}




\subsubsection{Reservatórios}

Os reservatórios do parasito são animais mamíferos, principalmente canídeos, sendo os mais importantes a raposa (no ciclo silvestre e rural) e o cão (no ciclo rural e, particularmente, nas áreas urbanas), espécies de roedores, marsupiais e edentados. Para a LV, na área urbana, o cão (Canis familiaris) é a principal fonte de infecção. A enzootia canina tem precedido a ocorrência de casos humanos e a infecção em cães tem sido mais prevalente que no homem. No ambiente silvestre, os reservatórios são as raposas (Dusicyon vetulus e Cerdocyonthous) e os marsupiais (Didelphis albiventris) (Brasil/MS/SVS, 2006).

\subsubsection{Vetores}

Há diferentes agentes transmissores dependendo da espécie de Leishmania e região geográfica. São insetos da Ordem Díptera, Família Psychodidae, Subfamília Phlebotominae, Gênero Lutzomyia (do sul dos EUA ao norte da Argentina) e Phlebotomus (na Europa, África do Norte, Oriente Médio e Ásia), cerca de 30 espécies são vetores no mundo (Desjeux, 1996). Os vetores das Leishmanioses são insetos denominados flebotomíneos, conhecidos popularmente como mosquito palha, tatuquiras, birigui, entre outros.

No Brasil, duas espécies estão relacionadas com a transmissão de LVA, Lutzomyia longipalpis e Lutzomyia cruzi. A primeira é considerada a principal espécie transmissora da Leishmania (L.) chagasi (Brasil/MS/SVS, 2006). As principais espécies envolvidas na transmissão da LTA são: Lutzomyia faviscutellata, L. whitmani, $L$. umbratilis, L. intermedia, L. wellcome e L. migonei (Brasil/MS/SVS, 2007).

Esses insetos são pequenos, medindo de 1 a $3 \mathrm{~mm}$ de comprimento. Possuem o corpo revestido por pêlos e são de coloração clara (castanho claro ou cor de palha). São facilmente reconhecíveis pelo seu comportamento, ao voar em pequenos saltos e pousar com as asas entreabertas. Estes insetos na fase adulta estão adaptados a diversos ambientes, porém na fase larvária desenvolvem-se em ambientes terrestres úmidos e ricos em matéria orgânica e de baixa incidência luminosa. Ambos os sexos necessitam de carboidratos como fonte energética e as fêmeas alimentam-se também de sangue para o desenvolvimento dos ovos. 
A distribuição geográfica de L. longipalpis é ampla e parece estar em expansão. Essa espécie é encontrada nas cinco regiões geográficas do país. A L. longipalpis adapta-se facilmente ao peridomicílio e a variadas temperaturas, podendo ser encontrada no interior dos domicílios e em abrigos de animais domésticos. Há indício de que o período de maior transmissão da LVA ocorra durante e logo após a estação chuvosa (Brasil/MS/SVS, 2006).

\subsubsection{Período de Incubação}

O período de incubação da LV é bastante variável tanto para o homem, como para o cão. No homem, é de 10 dias a 24 meses, com média entre 2 a 6 meses e, no cão, varia de 3 meses a vários anos, com média de 3 a 7 meses. O período de incubação da LC no ser humano é, em média, de 2 a 3 meses, podendo variar de 2 semanas a 2 anos (Brasil, SVS/MS, 2009).

\subsubsection{Ciclo Evolutivo}

A infecção do vetor ocorre quando as fêmeas, ao sugarem o sangue de mamíferos infectados, ingerem macrófagos parasitados por formas amastigotas da Leishmania. No trato digestório anterior ocorre o rompimento dos macrófagos liberando essas formas. Reproduzem-se por divisão binária e diferenciam-se rapidamente em formas flageladas denominadas promastigotas, que também se reproduzem por processos sucessivos de divisão binária. As formas promastigotas transformam-se em paramastigotas as quais colonizam o esôfago e a faringe do vetor, onde permanecem aderidas ao epitélio pelo flagelo, quando se diferenciam em formas infectantes - promastigotas metacíclicas (FIG. 04).

Após este período, as fêmeas infectantes, ao realizarem um novo repasto sanguíneo em um hospedeiro vertebrado liberam, as formas promastigotas metacíclicas juntamente com a saliva do inseto. $\mathrm{Na}$ epiderme do hospedeiro, estas formas são fagocitadas por células do sistema mononuclear fagocitário (SMF). No interior dos macrófagos, no vacúolo parasitóforo, diferenciam-se em amastigotas e multiplicam-se intensamente até o rompimento dos mesmos, ocorrendo a liberação destas formas que serão fagocitadas por novos macrófagos num processo contínuo. $\mathrm{Na} \mathrm{LV}$, as amastigotas disseminam-se utilizando o sistema vascular e linfático, infiltrando-se nos tecidos ricos em 
células do SMF, como linfonodos, fígado, baço e medula óssea. Na LC, as amastigotas infectam macrófagos dos tecidos locais (Chappuis et al., 2007)

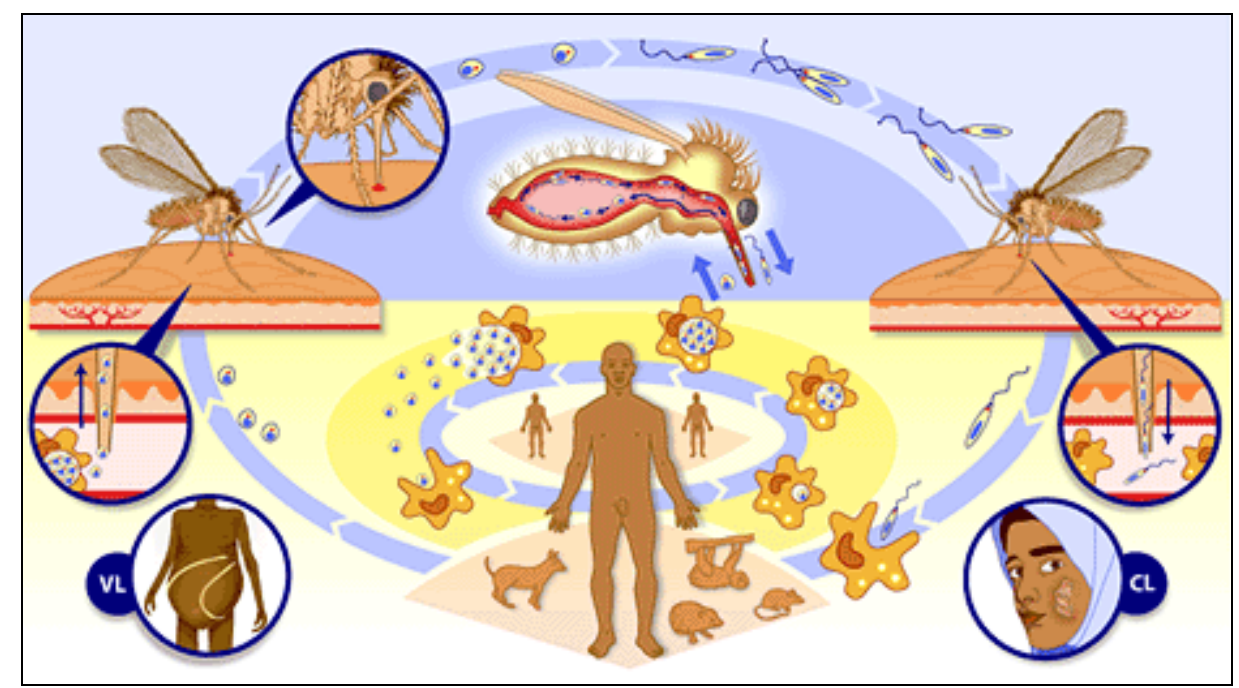

FIGURA 04 - Ciclo evolutivo das Leishmania sp. (OMS, 2010).

\subsubsection{Diagnóstico}

De modo geral, o diagnóstico da doença é baseado no exame clínico dos sintomas, no histórico fornecido pelo paciente e pela caracterização da área. O diagnóstico parasitológico é feito através do achado de formas amastigotas não flageladas intracelulares em esfregaços de biópsias de tecidos seccionados da pele, de lesões da mucosa ou tecidos viscerais (medula óssea, baço ou fígado) e também pode ser feito através do achado de formas promastigotas flageladas em cultura desses tecidos ou em inoculações em hamsters (Davies et al., 2003). As amostras para exame direto são preparadas em lâminas com coloração apropriada (Giemsa ou Leishman) e examinadas à microscopia óptica. No isolamento em cultura, as amostras são semeadas em meio de cultura para o crescimento de Leishmania sp. e observadas à microscopia óptica.

O diagnóstico laboratorial pode ser realizado por: ensaios sorológicos, entre os quais se destacam os testes de aglutinação direta (DAT), imunofluorescência indireta (IFI), ensaios imunoenzimáticos como ELISA, e ensaios moleculares, principalmente através de reação de polimerase em cadeia (PCR) (Guerin et al., 2002). O diagnóstico clínicoepidemiológico da LC e LMC pode ser complementado pela Intradermorreação de Montenegro (IDRM) e eventualmente pela resposta terapêutica. 


\subsubsection{Controle}

Estratégias de controle da doença variam em função de cada região geográfica, devido à variedade de características ecológicas, potenciais espécies de insetos vetores e, inúmeros animais considerados reservatórios potenciais. Em focos antroponóticos, onde o homem é o reservatório, a principal estratégia de controle é o tratamento dos indivíduos infectados, reduzindo assim, a transmissão da doença. Outra medida bastante importante é o controle do vetor através da utilização de inseticidas, porém grandes dificuldades vêm sendo apresentadas através dos numerosos casos de resistência dos insetos aos inseticidas (Guerin et al., 2002).

Em focos zoonóticos, onde o cão doméstico é o principal reservatório, as medidas de controle tornam-se problemáticas, devido à falta de estratégias que satisfaçam os interesses da comunidade, dos órgãos de Saúde Pública e, além disso, muitas medidas adotadas são inviáveis e por vezes ineficazes, pois o cão não responde adequadamente aos tratamentos e necessita ser sacrificado (Davies et al., 2003).

\subsubsection{Tratamento}

Como descrito anteriormente, Leishmania sp. são um grupo de protozoários encontrados em diversas regiões tropicais e subtropicais do mundo. Cada espécie apresenta um ciclo antroponótico ou zoonótico característico. Muitos destes parasitos provocam infecção no homem, ocasionando uma ampla variedade de manifestações clínicas. Cada região geográfica tem uma combinação única de cepas, vetores invertebrados, hospedeiros mamíferos e diversidade genética. Desta forma, um tratamento eficaz em uma área pode não ser eficaz em outra. Portanto, não é possível e nem desejável a recomendação de um único regime de tratamento que poderia ser seguro e efetivo para todas as formas da doença e em todas as regiões geográficas (Magill, 2000).

Assim, têm-se buscado diversas soluções para o tratamento das Leishmanioses, com a administração de diversos tipos de medicamentos. Atualmente, existem aproximadamente 25 compostos que apresentam atividade antileishmania, mas somente alguns são classificados como medicamentos para o tratamento da Leishmaniose Humana e a maioria destes é usada por via parenteral (Singh \& Sivakumar, 2004). Dentre os fármacos de primeira escolha estão os antimoniais pentavalentes orgânicos representados pelo antimoniato de meglumina (Glucantime®) e pelo estibogluconato de sódio 
(Pentostam®). Dentre os fármacos de segunda escolha estão as diamidinas aromáticas (Pentamidina), os antibióticos (Anfotericina B e Paromomicina) e os antifúngicos (Ketoconazol e Itraconazol), Alopurinol e o anticâncer Miltefosina.

Antimoniais pentavalentes. Em 1912, Gaspar de Oliveira Vianna observou que o tártaro emético ( $\mathrm{Sb}(\mathrm{III})$ ) era eficaz na terapêutica da LTA, porém devido aos seus efeitos tóxicos e graves efeitos colaterais, estes antimoniais trivalentes (TAB. 02) foram substituídos por compostos estibiados pentavalentes (Rath et al., 2003).

TABELA 02 - Estrutura química dos antimoniais trivalentes empregados na terapêutica das Leishmanioses (Rath et al., 2003).

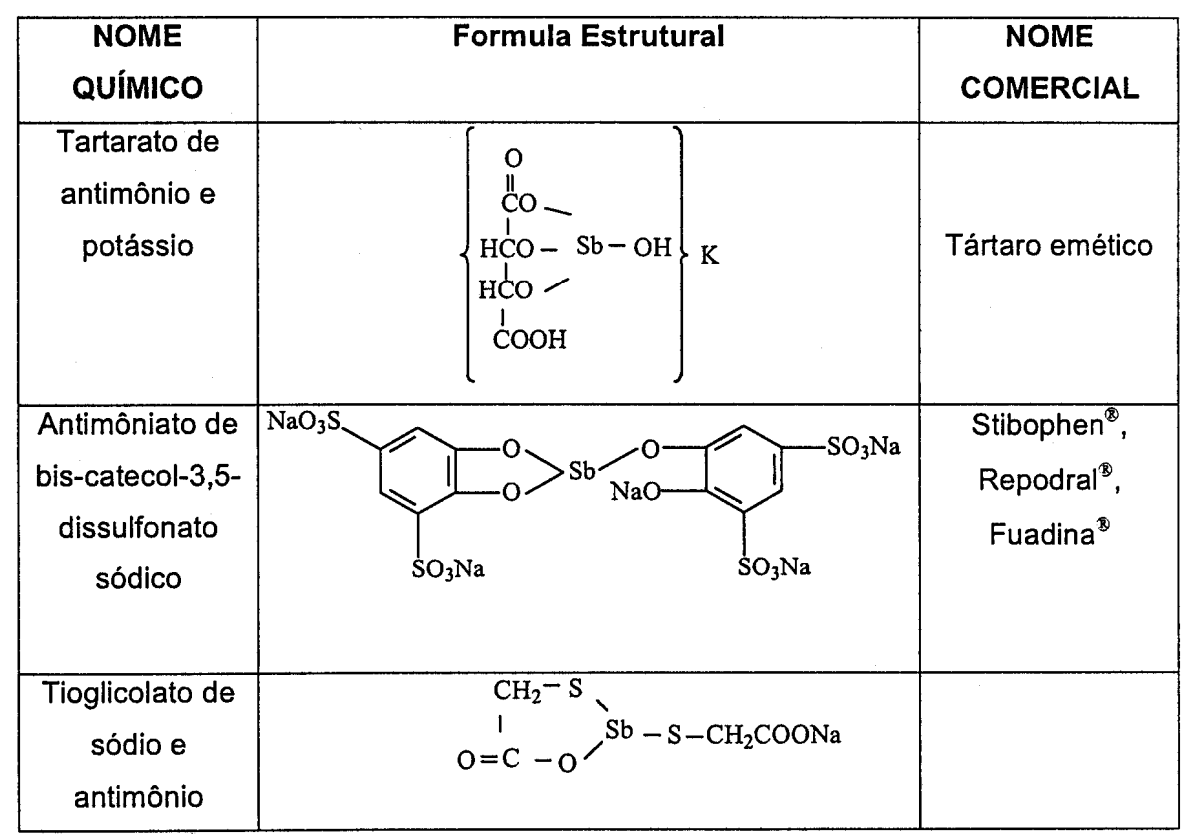

Em 1920, Bramachari desenvolveu o primeiro composto a base de antimônio pentavalente (TAB. 03), a uréia estibamina e em 1936, Schmidt introduziu um antimonial pentavalente mais estável o gluconato de antimônio (V) sódico, conhecido comercialmente como Solustibosan® (Bayer) ou Pentostam ${ }^{\circledR}$ (Glaxo Wellcome) (Marsden, 1985). Somente no final da Segunda Guerra Mundial foi desenvolvido na França um medicamento alternativo, o antimoniato de $\mathrm{N}$-metilglucamina, comercializado como Glucantime® (Rhône-Poulenc-Rohrer) (Marsden, 1985). Atualmente, o Pentostam ${ }^{\circledR}$ é manufaturado e comercializado nos países de língua inglesa e na Ásia, enquanto o Glucantime® é manufaturado e comercializado nos países de língua francesa e espanhola e na América Latina. As poucas diferenças entre os dois fármacos estão relacionadas à estabilidade e à toxicidade (Marsden \& Nonata, 1975). 
TABELA 03 - Estrutura química dos antimoniais pentavalentes empregados na terapêutica das Leishmanioses (Rath et al., 2003).

\begin{tabular}{|c|c|c|c|}
\hline Nome Químico & \multicolumn{2}{|c|}{ Formula estrutural proposta } & $\begin{array}{c}\text { Nome } \\
\text { comercial }\end{array}$ \\
\hline $\begin{array}{l}\text { Antimoniato de } \mathrm{N} \text { - } \\
\text { metilglucamina }\end{array}$ & 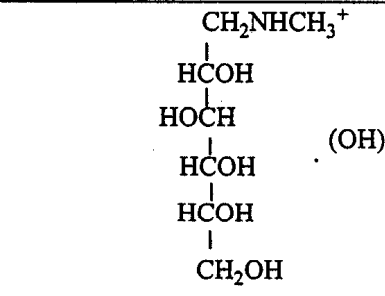 & $\mathrm{b}_{2} \mathrm{O}^{-}$ & Glucantime $^{(}$ \\
\hline $\begin{array}{l}\text { Gluconato de } \\
\text { antimônio (V) sódico } \\
\text { ou } \\
\text { Estibogluconato de } \\
\text { sódio }\end{array}$ & 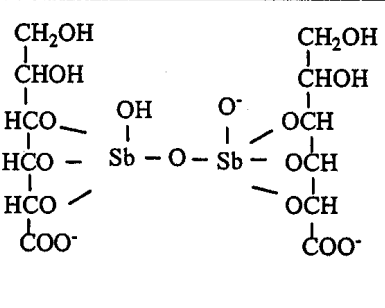 & $\mathrm{Na}_{3} .9 \mathrm{H}_{2} \mathrm{O}$ & $\begin{array}{l}\text { Pentostam }^{\circledR} \\
\text { Solustibosan }^{\oplus}\end{array}$ \\
\hline Uréia estibamina $^{16}$ & OH & & Estibamine $^{\circledR}$ \\
\hline
\end{tabular}

A fim de se reduzir os custos na utilização dos antimoniais pentavalentes em países subdesenvolvidos, uma formulação genérica do Pentostam foi produzida na Índia, envolvendo menor custo que a versão comercial e, após estudos de bioequivalência, revelou a mesma efetividade e segurança na utilização deste fármaco no tratamento de todas as formas de leishmaniose (Sundar \& Raí, 2002).

O mecanismo de ação dos antimoniais pentavalentes ainda não está bem elucidado, acredita-se que ajam pela depleção dos níveis intracelulares de Adenosina Trifosfato (ATP) e Guanosina Trifosfato (GTP), e pela inibição de enzimas da via glicolítica, devido à interferência no processo de glicólise e na $\beta$-oxidação de ácidos graxos em amastigotas de Leishmania spp. (Balaña-Fouce et al., 1998; Berman et al., 1988). Sugere-se que o antimônio pentavalente possa ser uma pró-fármaco, sendo convertido a antimônio trivalente após sua administração (Frézard et al., 2001). Há indícios que o antimônio trivalente é substancialmente mais eficiente que o antimônio pentavalente contra promastigotas e amastigotas (Roberts et al., 1995). Esses resultados reforçam a hipótese de uma conversão metabólica intramacrofágica do antimônio pentavalente em antimônio trivalente, sendo, este o elemento tóxico ao parasito no seu estado intracelular, já que o 
antimônio pentavalente é dez vezes menos tóxico para os humanos e tem um maior índice terapêutico que as preparações de antimônio trivalente (Roberts et al., 1995).

A conversão do antimônio pentavalente para a forma trivalente também pode ser verificada in vitro, através da incubação do fármaco na presença de uma enzima

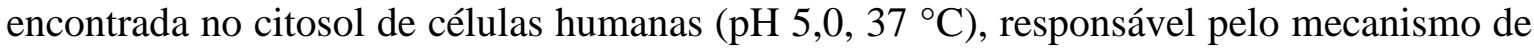
defesa contra danos oxidativos, denominada glutationa redutase (GSH). Baseado nestes resultados, o mecanismo de ação do antimoniato de meglumina envolve três etapas: primeiramente a entrada do fármaco em vacúolos digestivos do macrófago (fagolisossomas), através de difusão ligada a carboidratos na membrana plasmática, em seguida, a redução do antimônio pentavalente para trivalente na presença de tióis provenientes da célula hospedeira ou do próprio parasito e, finalmente, o acúmulo do antimônio trivalente e o contato com grupos sulfidrilas do parasito, causando sua morte (Frézard et al., 2001).

Alguns estudos evidenciam a participação de tióis específicos do parasito como a tripanotiona, bem como de tióis específicos do macrófago como a glicilcisteína, na redução do antimônio pentavalente para a forma trivalente, por meio de processo não enzimático (Ferreira et al., 2003). Em outro estudo verificaram uma provável redução mediada por enzimas, onde uma enzima específica do parasito, denominada TDR1, apresentou atividade catalítica na conversão do antimônio pentavalente para trivalente, usando a glutationa como redutor (Denton et al., 2004). É possível que mais de um mecanismo seja responsável pela ativação do fármaco, e a redução ou perda da ativação do fármaco pode ser um mecanismo pelo qual o parasito pode se tornar resistente (Ouellette et.al., 2004).

Os antimoniais pentavalentes apresentam alta eficácia em todas as formas de Leishmanioses, porém as baixas dosagens e tratamento descontínuo provocaram o aumento do número de relapsos e de cepas de Leishmania resistentes aos antimoniais pentavalentes (Guerin et al., 2002). Assim, a Organização Mundial de Saúde recomenda um regime de tratamento baseado em $20 \mathrm{mg} \mathrm{Sb/kg}$ diariamente, não ultrapassando $850 \mathrm{mg}$ de antimônio, por 20-40 dias, dependendo da área geográfica, podendo ser administrado via intravenosa ou intramuscular (Murray et al., 2005). O antimoniato de N-metilglucamina apresenta-se comercialmente em frascos de $5 \mathrm{~mL}$, que contém $1,5 \mathrm{~g}$ do antimoniato bruto, correspondente a $405 \mathrm{mg}$ de $\mathrm{Sb}(\mathrm{V})$, cada $\mathrm{mL}$ contém $81 \mathrm{mg}$ de $\mathrm{Sb}(\mathrm{V})$.

Alguns efeitos colaterais podem surgir com a sua utilização, tais como: artralgia, náusea, pancreatite, citopenia, cólicas abdominais, mialgias, alterações hepáticas 
e mudanças no padrão eletrocardiográfico, porém após o término do tratamento estes efeitos desaparecem (Murray et al., 2005).

Diamidinas aromáticas. A Pentamidina sintetizada primeiramente como agente hipoglicemiante (TAB. 04), tem sido utilizada como primeira terapia alternativa (segunda escolha) em alguns casos de leishmaniose, por exemplo, quando há resistência aos antimoniais pentavalentes (Balaña-Fouce et al., 1998). Em doses terapêuticas, os efeitos colaterais, após a administração destes fármacos, aparecem em 30 a $50 \%$ de pacientes tratados. Dentre esses efeitos é possível citar a taquicardia, lesões na pele, dores de cabeça e vômito. Após o tratamento contínuo, foram descritos efeitos como a hipotensão, hipoglicemia, alterações cardíacas, nefrotoxicidade e morte súbita (Balaña-Fouce et al., 1998). Além de ser tóxica e de serem relatados casos de resistência adquirida pelo parasito, o mecanismo de ação da pentamidina não é muito conhecido, sugere-se que sua atividade esteja relacionada a múltiplos alvos, interagindo com ácidos nucléicos do parasito e inibindo o processo de replicação e transcrição. Por causa da alta dose e do longo regime de tratamento, a pentamidina é provavelmente mais tóxica que os antimoniais pentavalentes, sendo somente indicada quando o tratamento será mais efetivo que com os antimoniais. Assim, a pentamidina deve ser usada onde é comum o tratamento com antimoniais apresentar falhas e em regiões onde não é amplamente utilizada (Berman, 1997).

Antibióticos poliênicos. A Anfotericina B é um antibiótico anfótero que se liga aos esteróis das membranas celulares, preferencialmente ao ergosterol que é o maior esterol das membranas celulares dos fungos e também da Leishmania, e altera a sua permeabilidade (TAB. 04), criando poros e provocando o extravasamento de íons, levando assim o parasito à morte (Misha et al., 1994). É usado predominantemente como um fármaco antifúngico, mas apresenta alta eficácia em cepas de Leishmania resistentes aos antimoniais e em casos de LV e LMC que não respondem ao tratamento com antimoniais. Porém, sua toxicidade e necessidade de ser administrada por infusão lenta durante quatro horas, representam suas grandes desvantagens. O uso de formulações lipídicas contendo anfotericina B (Ambisome, Albecet e Anfotec), as quais apresentam toxicidade reduzida e maior meia-vida plasmática, têm sido um dos maiores avanços no tratamento das Leishmanioses (Croft \& Coombs, 2003). No entanto, estes apresentam um custo muito elevado quando comparados aos antimoniais, inviabilizando sua utilização em países subdesenvolvidos. Além disso, em altas doses de administração foram observados efeitos adversos como: febre, diminuição dos níveis de potássio e magnésio e nefrotoxicidade 
(Balaña-Fouce et al., 1998). No Brasil, a dose preconizada é de $1 \mathrm{mg} / \mathrm{kg} / \mathrm{dia}$, durante 14 a 20 dias consecutivos, não devendo ultrapassar a dose máxima diária de $50 \mathrm{mg}$. A decisão quanto à duração do tratamento deve ser baseada na evolução clínica, considerando a velocidade da resposta e a presença de co-morbidades. Além disso, deve ser sempre administrada por via intravenosa, em infusão lenta de 2 a 6 horas.

TABELA 04 - Outros fármacos empregados na terapêutica das Leishmanioses (Rath et al., 2003).

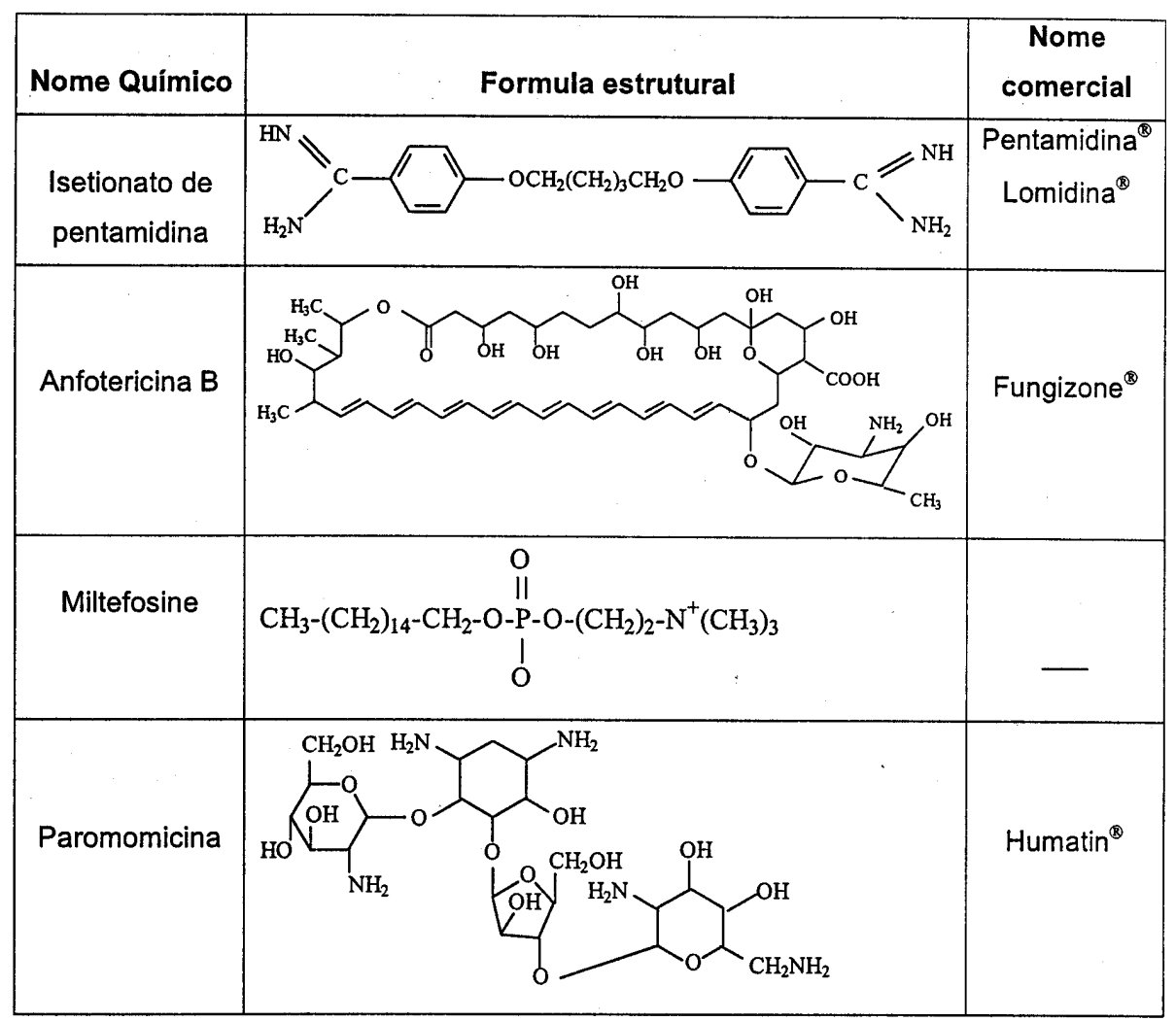

Aminoglicosídeo. A Paromomicina (TAB. 04) usada no tratamento de doenças bacterianas, quando injetado em associação com Pentostam mostrou resultados satisfatórios no tratamento de LV. Porém, a administração parenteral não apresentou resultados satisfatórios no tratamento de LC (Singh \& Sivakumar, 2004), enquanto a sua utilização em formulação tópica no tratamento de leishmaniose cutânea apresentou boa eficácia (Sundar \& Raí, 2002).

Antifúngicos. Outros fármacos de administração oral como Cetoconazol e Itraconazol produzem efeito antileishmania pelo bloqueio da síntese de ergosterol. O Alopurinol interfere na síntese protéica do parasito, em combinação com outros agentes antileishmania têm sido utilizados no tratamento da LC em alguns países da América 
Latina, porém este tipo de tratamento não tem sido recomendado (Singh \& Sivakumar, 2004).

Miltefosina (hexadecilfosfocolina). Um alquilfosfolipídio inicialmente desenvolvido como um agente anticâncer (TAB. 04), é ativo contra Leishmania sp. in vivo e in vitro. O mecanismo de ação do Miltefosina ainda não está bem esclarecido, mas está associado a mudanças no metabolismo alquifosfolipídico e na biossíntese de fosfolipídios (Ouellette et al., 2004). O Miltefosina é o primeiro tratamento oral para LV, visto que os resultados de estudos de fase IV, na Índia, indicaram boa tolerância e excelência na cura parasitológica. O Miltefosina foi registrado para o tratamento da LV na Índia em março de 2002, porém é um potencial teratogênico, e necessita ser usado com cuidado em mulheres e em crianças recém-nascidas, além de apresentar efeitos colaterais gastrintestinais (Chappuis et al., 2007).

Formas alternativas de tratamento. Recentemente, Interferon $\gamma$ recombinante tem sido utilizado como adjuvante em associação com antimoniais pentavalentes no tratamento de leishmaniose cutânea (Berman, 1997).

\subsubsection{Novas Estratégias Terapêuticas}

As Leishmanioses constituem um problema de saúde pública, consideradas doenças negligenciadas, sendo classificadas na categoria 1 do Programa Especial para Capacitação e Pesquisa em Doenças Tropicais (“Special Programme for Research and Training in Tropical Diseases" - TDR), como doenças emergentes ou fora do controle, onde o foco deve ser na geração de novos medicamentos e no desenvolvimento de novas intervenções e sistemas (TDR/OMS). Além disso, é considerada pela Organização Mundial da Saúde (OMS), como uma das seis mais importantes doenças infecciosas. Mesmo assim, para as Leishmanioses ainda existem pouco ou quase nenhum investimento financeiro direcionado à pesquisa e desenvolvimento de novos agentes terapêuticos (Lindoso \& Lindoso, 2009).

As doenças negligenciadas são doenças que afetam milhares de pessoas ao redor do mundo, mas que não dispõem de tratamentos eficazes ou adequados. Em sua maioria, são doenças tropicais infecciosas que afetam principalmente pessoas pobres, a exemplo das Leishmanioses, da Doença do Sono, da Malária, e da Doença de Chagas, que geram um impacto devastador sobre a humanidade. Há um grande volume de trabalhos científicos que tratam da biologia, imunologia e genética dos parasitos causadores destas 
doenças, porém todo esse conhecimento não consegue se reverter em novas ferramentas terapêuticas para as pessoas afetadas. Ao contrário, tais doenças têm sido progressivamente marginalizadas por aqueles encarregados pelos programas de pesquisa tanto do setor público quanto do privado, essencialmente porque as pessoas que sofrem de doenças negligenciadas são pobres, e não oferecem um retorno lucrativo suficiente para que a indústria farmacêutica invista em pesquisa e desenvolvimento de novos medicamentos voltados para essas doenças. Fica claro, portanto, que a crise de falta de medicamentos para doenças negligenciadas não chegou às atuais proporções por falta de conhecimento científico, e nem somente pelo hiato entre a pesquisa básica e a pré-clínica. Esta crise é o resultado tanto das insuficientes políticas públicas voltadas para Pesquisa e Desenvolvimento (P\&D) de medicamentos de interesse nacional dos países em desenvolvimento, quanto da falha de mercado, provocada pelo baixo interesse econômico que esses pacientes representam para a indústria (DNDi, 2009).

Cabe ressaltar que existem poucos fármacos novos no mercado mundial e, tratando-se de doenças tropicais sabe-se que das 1.393 substâncias químicas terapêuticas introduzidas e comercializadas no mundo inteiro entre 1975 e 1999, 31 \% são realmente inovações terapêuticas e menos de $1 \%$ destas inovações foram destinadas às doenças tropicais que incluem dentre outras doenças as próprias Leishmanioses (Trouiller et al., 2002).

Entre 2000 e 2004, foram introduzidas e comercializadas 163 novas substâncias químicas terapêuticas, somando um total de 1.556 substâncias nos últimos 30 anos (1975 a 2004), sendo 4 novos fármacos visando as doenças negligenciadas. No total, o número de fármacos direcionados para estas doenças chega a 10. Se as doenças mais negligenciadas como a malária forem consideradas atinge $18 \mathrm{e}$, se somar para tuberculose a 21. Esses dados ainda representam apenas cerca de $1 \%$ dos novos fármacos (1.556) lançados no mercado mundial, situação que foi essencialmente inalterada nos últimos anos (Chirac \& Torreele, 2006).

\subsubsection{Macrófagos}

Os macrófagos são as células mais diferenciadas do Sistema Mononuclear Fagocítico (SMF), o qual compreende monoblasto e promonoblasto da medula óssea, monócitos periféricos e macrófagos teciduais. Os precursores de macrófagos são os monócitos, promonócito e monoblasto. Todas essas células provêm de um mesmo 
progenitor denominado unidade formadora de colônia granulócito-macrófago. Os monoblastos, última célula madura do SMF, primeiramente diferenciam-se em monócitos e permanecem na medula óssea por $24 \mathrm{~h}$ e, então migram para o sangue periférico. Posteriormente, migram para o tecido extravascular onde se diferenciam em macrófagos. Os macrófagos colonizam o fígado (célula de Kupffer), pulmão (macrófagos intersticial alveolar), baço, linfonodos, timo, intestino, medula, cérebro, tecido conjuntivo e cavidades serosas (Pollard, 2009). Eles desempenham um importante papel na defesa do hospedeiro contra muitos agentes infecciosos incluindo bactérias, vírus, protozoários e parasitos; induzem e regulam a resposta imune; inibem a divisão celular em tumores; regulam a hematopoiese; regulam a hemostase; limpam e curam tecidos lesionados e, servem como célula hospedeira/reservatório para muitos microorganismos (Ahsan et al., 2002).

$\mathrm{Na}$ fisiopatogenia das Leishmanioses, os macrófagos são ao mesmo tempo células hospedeiras, apresentadoras de antígeno para o sistema imune e efetor para a destruição do parasito (Naderer \& McConville, 2008). Nos macrófagos, os parasitos internalizados ficam dentro de um vacúolo parasitóforo (fagolisossoma), que os separa do citoplasma celular. Esta organela deriva da fusão do fagossoma, resultante da fagocitose dos parasitos com os lisossomas, que contêm substâncias responsáveis pela destruição de microorganismos. Embora os macrófagos sejam células fagocitárias especializadas no combate a agentes infecciosos, as leishmanias desenvolverem mecanismos de defesa capazes de subverter sua capacidade microbicida, conseguindo sobreviver neste ambiente potencialmente tóxico e multiplicar-se até a ruptura da célula, quando são liberadas para infectar outros macrófagos, propagando a infecção. Este processo leva à liberação de partículas antigênicas que serão apresentadas ao sistema imune, gerando a resposta específica. As formas promastigotas que não forem internalizadas serão destruídas no meio extracelular pela resposta inata e as partículas antigênicas produzidas neste processo também poderão ser utilizadas pelas células apresentadoras de antígeno no processo de reconhecimento antigênico (Kima, 2007). É provavelmente neste momento que características como intensidade e qualidade da resposta imune sejam definidas, influenciando assim a evolução da doença para cura espontânea, formas autolimitadas ou formas progressivas (Brasil, SVS/MS, 2007).

A localização das amastigotas de Leishmania sp. no interior de macrófagos faz com que o microorganismo fique protegido do sistema de defesa do hospedeiro, resposta imune mediada por células e, dificulta a penetração dos agentes terapêuticos na célula fagocítica. Uma estratégia para aumentar a captação de medicamentos pelas células é o uso 
de sistemas transportadores que entregam a fármaco diretamente na célula alvo. Os sistemas de entrega de fármacos ("Drug Delivery Systems") como lipossomas, micropartículas, nanopartículas, sistemas lipídicos, conjugados e transportadores biológicos podem contribuir para a melhora da eficácia terapêutica de agentes antibióticos e antifúngicos no tratamento de infecções causadas por microorganismos intracelulares (Briones et al, 2008).

A Organização Mundial de Saúde recomenda a pesquisa de novos medicamentos, através de sua agência TDR ("Special Programme for Research and Training in Tropical Diseases"). Estratégias para o desenvolvimento de novos medicamentos envolvem o planejamento/síntese de novas substâncias ativas ou de fármacos já conhecidos com modificações químicas. Outra estratégia envolve a associação reversível do fármaco já em uso a um sistema transportador, a fim de direcioná-lo ao local alvo, reduzindo sua toxicidade e efeitos colaterais. Esta última estratégia, além de prolongar a validade de proteção por patente no uso do fármaco, oferece vantagens na fase de desenvolvimento, por utilizar um medicamento já caracterizado farmacologicamente. Entre os sistemas transportadores de medicamentos disponíveis, os lipossomas apresentamse bastante promissores na terapia antileishmania (Frézard et al., 2005).

\subsubsection{Lipossomas}

No início do século passado, Paul Ehrlich propôs pela primeira vez um sistema direcionado de transporte de fármacos, um modelo que ficou conhecido por "Bala Mágica de Ehrlich" (Ehrlich's Magic Bullet), onde o fármaco era ligado ao transportador, direcionando-o ao tecido alvo. Na década de 1960, Alec Bangham e colaboradores demonstraram a capacidade das vesículas lipídicas artificiais oferecerem barreiras para a difusão de solutos e, posteriormente, este sistema foi denominado lipossoma (Santos \& Castanho, 2002).

Somente na década de 1970, Gregory Gregoriadis propôs a utilização de lipossomas como sistema transportador de fármacos, onde ele sugeriu que a liberação do fármaco resultava da difusão acelerada através da membrana lipossomal. A liberação do conteúdo lipossomal está baseada no fato que o lipossoma perde toda ou parte de sua estabilidade em diferentes meios e como resultado expõe seu conteúdo para o meio externo, no entanto, a cinética de liberação do lipossoma pode ser controlada pela alteração de sua estabilidade (Anderson \& Omri, 2004). Na década de 1970, também foram 
apresentados os primeiros resultados deste sistema direcionado ao tratamento das Leishmanioses (Black et al., 1977).

Os lipossomas são estruturas esféricas, formadas por uma ou várias bicamadas concêntricas de lipídios que isolam um ou vários compartimentos aquosos internos, do meio externo. Apresentam diâmetros variáveis $(0,05-5,0 \mu \mathrm{m})$ que se formam espontaneamente quando os lipídios são hidratados em solução aquosa (FIG. 05).

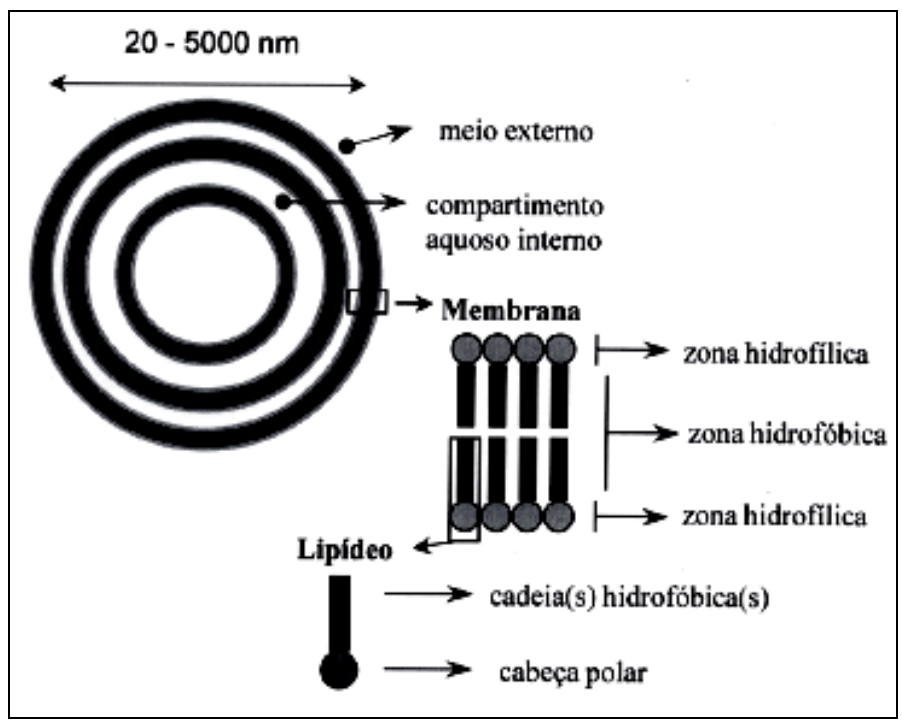

FIGURA 05 - Características estruturais dos lipossomas (Frézard et al., 2005).

Eles apresentam diversas propriedades biológicas atraentes como biodegradabilidade e biocompatibilidade, são constituídos de lipídios sintéticos ou naturais em suas membranas (Uhumwangho \& Okor, 2005). Podem encapsular agentes farmacêuticos hidrossolúveis e insolúveis em seu compartimento interno e em sua membrana, respectivamente. Os agentes incorporados em lipossomas ficam protegidos dos processos metabólicos que eventualmente possam degradá-los na circulação sanguínea antes de atingir seu alvo, com redução das reações indesejáveis. Além disso, os lipossomas apresentam a vantagem particular de transportar produtos farmacêuticos às células ou até mesmo a compartimentos celulares individuais (Torchilin et al., 2005). Os lipossomas têm apresentado melhora na eficácia e redução da toxicidade sistêmica de fármacos, especificamente como transportadores de fármacos antifúngicas, antitumorais e antibióticos (Schwendener, 2007).

Alving e colaboradores, a partir de 1977-78, demonstraram primeiramente, a atividade de antimoniais encapsulados em lipossomas no tratamento experimental de LV em hamsters, onde verificaram que estes foram 300 - 700 vezes mais ativos que o fármaco 
não encapsulado (Alving et al., 1978 a,b). New e colaboradores (1978) utilizaram lipossomas com diferentes agentes antimoniais e obtiveram resultados similares de supressão parasitária em camundongos portadores de leishmaniose visceral experimental, com aumento da atividade antileishmania dos compostos encapsulados em lipossoma.

Em 1984, Chapman e colaboradores, utilizando uma formulação de antimônio lipossomal, trataram cachorros portadores de leishmaniose visceral experimental e observaram 89 - 96 \% de redução do parasito no baço, verificaram que a dose necessária para provocar $50 \%$ de supressão parasitária era de aproximadamente 0,029 mg de Sb/kg para a formulação lipossomal e para o fármaco livre $24 \mathrm{mg}$ de $\mathrm{Sb} / \mathrm{kg}$, mostrando que a eficácia da formulação lipossomal era 700 vezes superior ao fármaco não encapsulado (Chapman et al., 1984). Após estes resultados promissores, a pesquisa de novos medicamentos lipossomais foi interrompida devido ao achado de toxicidade hepática, reportada apenas em congressos e reuniões científicas.

Recentemente, surgiram novos estudos com lipossomas para o tratamento das Leishmanioses. Frézard e colaboradores demonstraram a eficácia de um antimônio lipossomal liofilizado no tratamento de hamsters experimentalmente infectados com Leishmania chagasi, onde verificaram uma significante redução do parasito no fígado destes animais, além disso, observaram que o antimoniato de meglumina livre era ineficiente quando administrado em doses comparáveis de antimônio (Frézard et al., 2000). Em 2005, o mesmo grupo demonstrou uma elevação do nível de antimônio e redução do número de parasitos na medula óssea de cachorros naturalmente portadores de leishmaniose visceral e tratados com injeções múltiplas intravenosas de uma formulação de antimônio lipossomal liofilizado (Schettini et al., 2005). Posteriormente, o mesmo grupo, tratou cachorros naturalmente infectados com Leishmania chagasi com antimônio encapsulado em lipossomas de tamanho reduzido (aproximadamente $400 \mathrm{~nm}$ ) e observou uma significante elevação dos níveis de antimônio teciduais nos órgãos do sistema mononuclear fagocítico e, ainda uma elevação de aproximadamente três vezes dos níveis de antimônio na medula óssea quando comparado com os lipossomas de maior tamanho (1200 nm), sugerindo que a redução do tamanho dos lipossomas promove uma maior captação pela medula óssea, órgão crítico na cura da Leishmaniose Visceral (Schettini et al., 2006).

Considerando a resistência associada aos antimoniais, foram realizados estudos avaliando a eficácia dos agentes de segunda escolha como a anfotericina $\mathrm{B}$ e a pentamidina. Estudos experimentais mostraram que a dose de pentamidina pode ser 
reduzida em 13 vezes, com a mesma eficácia para o tratamento da LV, quando encapsulada em lipossomas (Fusai et al., 1997). A anfotericina B quando encapsulada em lipossoma e utilizada no tratamento da Leishmaniose, mostrou ser 350 - 750 vezes mais ativa que o antimoniato de meglumina e 2 - 5 vezes mais ativa que a anfotericina $B$ não encapsulada. Além disso, a anfotericina B lipossomal quando testada em macacos, provocou $99 \%$ de supressão de amastigotas de Leishmania no fígado, com concomitante melhora do índice terapêutico da anfotericina B (Berman et al., 1986). Recentemente algumas formulações lipídicas de anfotericina B têm sido usadas clinicamente com a redução dos níveis de toxicidade, porém apresentam um elevado custo. $\mathrm{O}$ AmBisome ${ }^{\circledR}$ é o único produto lipossomal aprovado para ser utilizado no tratamento de LV em adultos e crianças, além do que é considerado como primeira escolha no tratamento de pacientes que apresentam resistência aos agentes antimoniais. Além de diminuir a toxicidade no organismo, a anfotericina B lipossomal apresenta-se mais efetiva em doses menores quando comparada a elevadas doses do fármaco livre (Meyerhoff, 1999). Cabe ressaltar que estes lipossomas apresentam o composto ativo incorporado na membrana lipídica, sendo pouco importante seu volume interno.

Terapias alternativas para Leishmaniose Visceral têm resultado no desenvolvimento de compostos antimoniais encapsulados em lipossomas, com aumento da eficácia e do índice terapêutico (Tempone et al., 2004, Pal et al., 2004; Carter et al., 1988). Entretanto, apesar da necessidade de aprimorar a quimioterapia antimonial atual e dos resultados extremamente promissores obtidos com os lipossomas em modelos experimentais de LV, atualmente nenhuma formulação lipídica de antimônio está disponível comercialmente. Este fato pode ser justificado, em parte, pelas dificuldades tecnológicas inerentes à obtenção de formulações estáveis de compostos hidrossolúveis encapsulado em lipossomas (Frézard et al., 2005).

O primeiro método proposto para a encapsulação dos antimoniais pentavalentes em lipossomas foi o método de "hidratação do filme lipídico", porém não permite alcançar altas taxas de encapsulação comparado aos outros métodos (Bangham et $a l .$, 1965). Outra técnica avaliada foi a do método de "evaporação em fase reversa", porém apresenta menor estabilidade, além do que, pode apresentar resíduos de solvente orgânico potencialmente tóxico (Szoka \& Papahadjopoulos, 1978). Outro inconveniente destes dois métodos é que as preparações resultantes só podem ser armazenadas na forma de suspensão aquosa, o que limita seu potencial farmacológico (Frézard et al., 2005).

Recentemente, Frézard e colaboradores avaliaram outro método denominado 
“desidratação-reidratação de vesículas", obtendo lipossomas com alta taxa de encapsulação (Frézard et al., 2000). O mesmo grupo, realizando uma alteração neste método, propôs a liofilização dos lipossomas pequenos vazios sem o antimonial e a reidratação do liofilizado com a solução de antimonial, chamando-o de "lipossomas vazios liofilizados" ("freezedried empty liposomes"- FDEL), obtendo alta taxa de encapsulação, além de não submeter o antimonial à liofilização. Outra vantagem associada a este método quando comparado aos métodos convencionais é o fato que a preparação pode ser armazenada por tempo prolongado na forma liofilizada intermediária e reidratada somente um pouco antes do uso (Schettini et al., 2006).

Para que possam ser considerados ideais na terapêutica, carregadores de fármacos, como os lipossomas, devem basicamente apresentar três requisitos primordiais: primeiramente devem proteger o fármaco dos processos metabólicos que eventualmente possam degradá-lo na circulação sanguínea antes de atingir seu alvo; devem proteger os tecidos adjacentes de uma elevada captação do fármaco, concentrando-se majoritariamente no órgão ou células a que se destina atingir e finalmente, devem aumentar a captação pelas células do tecido-alvo, aumentando a eficácia do fármaco em relação a sua formulação não lipossomal (Fusai et al., 1995).

Outros fatores também devem ser analisados para a escolha de uma formulação lipossomal mais adequada, visto que vários fatores determinam a interação dos lipossomas com as diferentes células sanguíneas e mesmo tecidos, após sua administração sistêmica. Os principais são o tamanho do lipossoma, suas características físico-químicas, a carga de superfície e a fluidez da membrana fosfolipídica (Lopez-Berestein, 1987). A presença de fosfolipídios com uma temperatura de transição de fase $\left(\mathrm{T}_{\mathrm{c}}\right)$ maior que $37{ }^{\circ} \mathrm{C}$ confere aos lipossomas uma membrana com maior estabilidade físico-química e menor susceptibilidade ao rompimento e extravasamento do seu conteúdo interno. A adição de colesterol na formulação lipossomal proporciona o aumento da fluidez da membrana (Lopez-Berestein, 1987), assim como a redução da interação com proteínas plasmáticas, as quais contribuem para a desestabilização e ruptura dos lipossomas.

A ausência de carga na superfície do lipossoma faz com que a estabilidade física seja diminuída, causando sua agregação e fusão. A adição de fosfolipídios carregados negativamente como fosfatidilglicerol ou fosfatidilserina, impedem este fenômeno, aumentando ainda a captação dos lipossomas pelas células (Lopez-Berestein, 1987).

A hipótese do sucesso da terapia lipossomal é devido ao fato de que tanto o 
parasito como os lipossomas são captados pelo sistema mononuclear fagocítico, isto é, são captados pelos mesmos órgãos (fígado, baço e a medula óssea) e pelas mesmas células (macrófagos teciduais) nas quais se localiza o parasito (Heath et al., 1984). A encapsulação de compostos em lipossomas é uma ferramenta importante para a melhoria das propriedades farmacológicas de fármacos. No entanto, os mecanismos envolvidos na eliminação dos lipossomas do compartimento sanguíneo ainda são não totalmente compreendidos (FIG. 06).
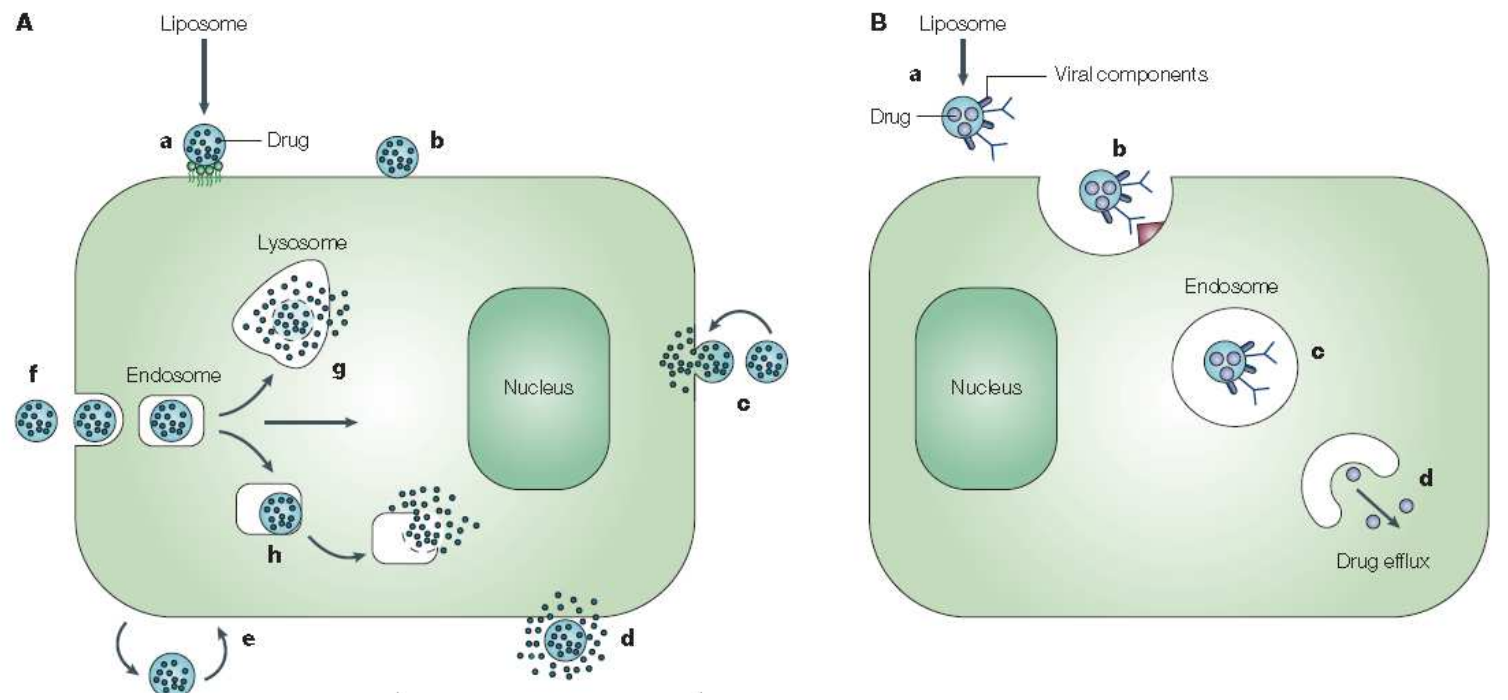

FIGURA 06 - Interação lipossoma-célula. A| Lipossomas (Liposome) podem especificamente (a) ou não especificamente (b) adsorver na superfície da célula. Os lipossomas podem também se fundir com a membrana da célula (c) e, liberar o seu conteúdo no citoplasma da célula ou podem ser desestabilizados por certos componentes de membrana da célula quando adsorvidos na superfície (d) assim a fármaco (drug) liberada pode entrar na célula via micropinocitose. Os lipossomas podem ser submetidos a troca direta ou transferência mediada por proteínas dos componentes lipídicos com a membrana da célula (e) ou ser submetidos a uma endocitose específica ou não específica (f). No caso de endocitose, o lipossoma pode ser entregue pelo endossomo (endosome) ao lisossomo (lysosome) ( $\mathrm{g}$ ) ou na rota para o lisossomo, o lipossoma pode provocar a desestabilização de endossomo (h), que resulta na liberação de fármaco no citoplasma da célula. B| Lipossoma modificado com componentes específicos virais (viral components) (a) e carregado com fármaco pode especificamente interagir com células (b), provocar endocitose e, através da interação dos componentes virais com membrana interna do endossomo (c), permitir o efluxo de fármaco (drug efflux) no citoplasma (d) (Torchilin, 2005).

A captura celular dos lipossomas é favorecida pelo processo de opsonização, que ocorre assim que os lipossomas entram em contato com os componentes do sangue. Nesta fase, as proteínas do complemento C3b ligam-se à superfície dos lipossomas e 
servem como sinal para os macrófagos fagocitarem. Depois da fagocitose, os lipossomas são degradados pelas fosfolipases lisossomais e a substância é liberada nos fagolisossomas, podendo se difundir para o citosol, atingindo diretamente o parasito, ou ser excretada para o meio extracelular (Alving et al., 1978; Frézard et al., 2005).

Assim, a interação entre o lipossoma e a célula-alvo é um dos papéis chave no desenvolvimento adequado desse sistema lipossomal. Os lipossomas convencionais formados de fosfatidilcolina ou de surfactantes não-iônicos e de colesterol apresentam-se como sistema ideal para direcionar fármacos leishmanicidas para o local da infecção, visto que os lipossomas quando administrados por via intravenosa são capturados pelos macrófagos do SMF e não penetram nos órgão que apresentam capilares contínuos, promovendo a redução da concentração do fármaco neste local, e aumentando-a nos locais alvos (Frézard et al., 2005)

Estratégias recentes têm sido desenvolvidas com o objetivo de controlar sua estabilidade e reatividade após administração sistêmica. O direcionamento de lipossomas contendo fosfatidilserina às células do SMF tem sido mostrado como um caminho viável, uma vez que os receptores "scavenger" (ScavR) vêm sendo demonstrados como um dos principais receptores de macrófagos responsáveis pela rápida eliminação destes lipossomas do compartimento sanguíneo além de participarem da captação e internalização de amastigotas de L. (L.) chagasi (Tempone et al., 2004). Além disso, a mimetização de uma célula apoptótica, devido à inclusão de fosfatidilserina na membrana lipídica dos lipossomas, mostrou um significativo aumento da efetividade in vitro, sendo até 16 vezes mais efetivo, com eficiência ainda maior in vivo, pelo menos 133 vezes mais efetivo, quando comparado à formulação livre (Tempone et al., 2008). A ampla especificidade dos ScavR por moléculas polianiônicas os torna candidatos potenciais para a ligação e internalização de lipossomas contendo fosfolipídios carregados negativamente, sendo úteis para o direcionamento de antimônio pentavalente às células-alvo, ou seja macrófagos contendo amastigotas.

\subsubsection{Estudos Farmacológicos de Antimonial Encapsulado em Lipossomas}

No desenvolvimento de fármacos lipossomais, a farmacocinética, a biodistribuição e a captação celular de tais sistemas são questões importantes a serem verificadas. Para investigar o destino de lipossomas in vitro e in vivo, uma grande variedade de marcadores lipossomais está disponível, sendo que agentes radiomarcadores e 
corantes fluorescentes fornecem uma ferramenta sensível e poderosa para determinar essas propriedades (Kamps et al., 2004).

\subsubsection{Determinação de Antimônio}

Para a determinação da biodistribuição do antimônio em um sistema in vivo é necessária a utilização de métodos de determinação de antimônio em sistemas biológicos. A metodologia analítica descrita na literatura para a determinação de antimônio baseia-se, principalmente, nas técnicas físicas associadas ou hifenadas e em métodos volumétricos e/ou potenciométricos. As técnicas hifenadas permitem simultaneamente separar e quantificar as espécies de $\mathrm{Sb}(\mathrm{V}), \mathrm{Sb}(\mathrm{III})$ e organoantimoniais, diminuindo assim a introdução de erros provenientes da determinação indireta. Entre as técnicas hifenadas destacam-se a eletroforese capilar com espectrometria de massa com fonte de plasma acoplado indutivamente (CE-ICP-MS), cromatografia líquida de alta eficiência com espectrometria de fluorescência atômica com geração de hidretos (HPLC-HG-AFS) e a cromatografia líquida de alta eficiência com espectrometria de absorção atômica e geração de hidretos (HPLC-HG-AAS). Embora esses métodos sejam promissores, são inviáveis para o estudo de um grande número de amostras, são demorados e de elevado custo. Além disso, os métodos analíticos utilizados para determinação da concentração de antimônio em sistemas biológicos são complexos e de baixa sensibilidade (Rath et al., 2003).

Para melhorar as propriedades físico-químicas dos lipossomas é imperativo conhecer a concentração do fármaco encapsulada. Como o antimoniato de meglumina é um composto obtido sinteticamente a partir do ácido antimônico e da N-metilglucamina, uma mistura complexa de polímeros de carboidratos-antimônio, uma metodologia precisa para determinar a quantidade de antimônio se faz necessária. Vários métodos espectrométricos têm sido utilizados para a determinação de antimônio. A maioria destes é caracterizada por elevada eficiência, reduzido volume de amostra, baixo consumo de reagente e maior tolerância das interferências. No entanto, todos estes métodos apresentam elevado custo, exigência de pessoal treinado e não são aplicáveis para a detecção rápida de analito (Rath et al., 2003).

A espectrofotometria é uma técnica simples, rápida e versátil para a determinação de substâncias. Reagentes como, leucocristal de violeta (Tiwari et al., 2006) e vermelho de bromopirogalol (Rath et al., 1997) foram relatados para a determinação de 
quantidades traço de antimônio. Os métodos são sensíveis, mas têm baixa seletividade, reprodutibilidade e são aplicáveis apenas a amostras específicas (Tiwari et al., 2006).

Muitos métodos permitem apenas a determinação do elemento em um dos estados de oxidação, sendo outros determinados indiretamente. Embora esses métodos sejam promissores para a especiação de antimônio, eles não são viáveis para aplicação no controle de qualidade dos medicamentos, visando a determinação do teor de $\mathrm{Sb}(\mathrm{V})$ e possíveis contaminantes tóxicos, sendo necessários métodos simples, baratos e com aplicação em larga escala.

A determinação de antimônio pentavalente no estibogluconato de sódio (Pentostam), segundo a monografia contida na Farmacopéia Britânica, é realizada mediante titulação potenciométrica do antimônio com sulfato ferroso amoniacal. No entanto, essa metodologia, além de ser lenta, carece de precisão (Rath et al., 2003). A farmacopéia brasileira recomenda a análise por meio de espectrofotometria de absorção atômica com geração de hidretos, sistema em batelada.

A Análise por Ativação Neutrônica Instrumental (AAN) é amplamente conhecida por sua sensibilidade para detecção e determinação de um grande número de elementos químicos. Este método consiste basicamente da produção de radionuclídeos artificiais a partir de elementos estáveis por meio da irradiação com um fluxo de nêutrons e medida das radiações emitidas pelos radionuclídeos formados. A reação nuclear (FIG. 07) mais comum utilizada em AAN é a reação de captura de nêutrons térmicos, ou a reação tipo $(\mathrm{n}, \gamma)$, por ativação nuclear (1):

$$
{ }_{\mathrm{Z}}^{\mathrm{A}} \mathrm{X}(\mathrm{n}, \gamma){ }_{\mathrm{Z}}^{\mathrm{A}+1} \mathrm{X}
$$

Onde: $\mathrm{X}=$ elemento químico

$\mathrm{Z}=$ número atômico do elemento

$\mathrm{A}=$ número de massa do elemento

O núcleo produto é radioativo e decai, em geral, pela emissão de partículas $\beta^{-} \mathrm{e}$ pela emissão de radiação gama, formando por fim um núcleo estável. Por meio da energia da radiação gama de decaimento e da respectiva meia-vida, o radioisótopo formado (núcleo produto) na reação nuclear pode ser identificado, permitindo assim realizar análises qualitativas e quantitativas do elemento contido na amostra. 


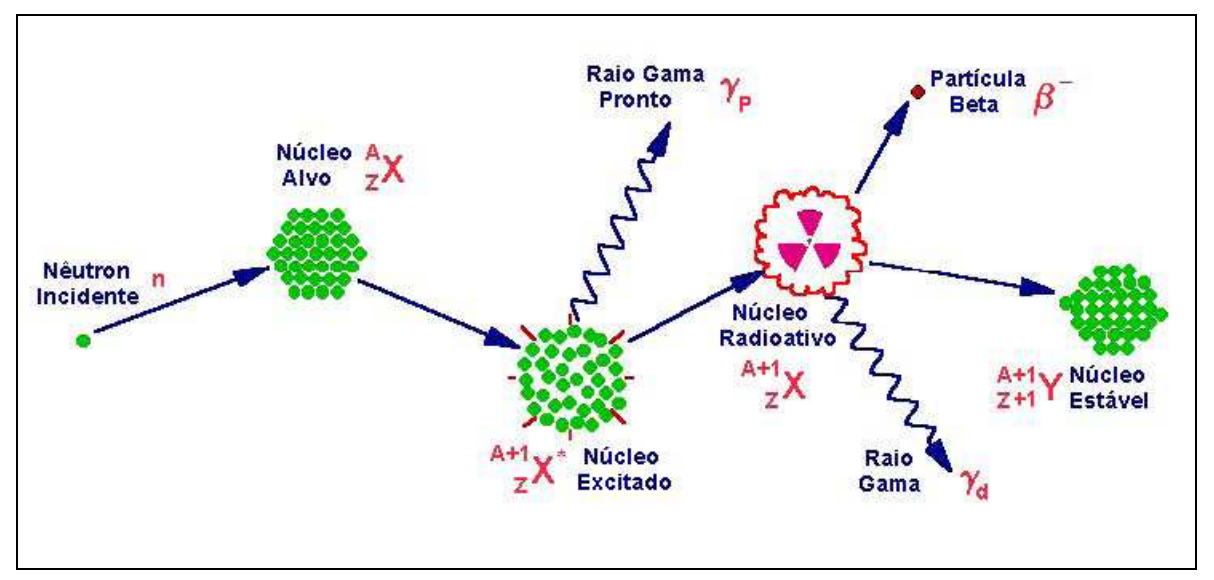

FIGURA 07 - Representação esquemática da interação do nêutron com um núcleo alvo, reação tipo $(n, \gamma)$.

A AAN apresenta boa sensibilidade e seletividade para medir o antimônio em níveis traços e, apresenta a vantagem de ser independente da matriz de amostra e do processo de digestão ou extração. Além disso, na disponibilidade de um reator nuclear, esta análise se torna mais fácil, rápida e com custo reduzido comparado a um método analítico convencional (Osso et al., 2009). Dorea e colaboradores (1987) determinaram antimônio em amostras de cabelo de indivíduos portadores de Leishmaniose e tratados com antimoniato de meglumina por AAN. Posteriormente, o mesmo grupo (1990) estudou a retenção de antimônio na pele de indivíduos com Leishmaniose e tratados com antimoniato de meglumina utilizando a AAN.

Este método apresenta vantagens em relação aos métodos químicos de análise por eliminar o ataque químico às amostras, pela ausência de branco analítico, independência em relação à forma química dos elementos, necessidade de pequena quantidade de amostra, além da precisão, exatidão e sensibilidade, permitindo a determinação dos elementos em concentrações da ordem de parte por bilhão (ppb) até porcentagens do elemento na amostra. Uma desvantagem desta metodologia é a impossibilidade de realizar a especiação de antimônio, uma vez que somente é avaliada a relação de antimônio total na amostra. Dentre os diversos materiais que podem ser analisados utilizando a AAN, seguem alguns exemplos: amostras geológicas: solos, rochas, carvão, minérios, concentrados minerais, plásticos, resinas e outros produtos industriais, catalisadores, petróleo, amostras arqueológicas, metais e ligas: aços, silício metálico, ligas nióbio-tântalo, amostras agropecuárias: pêlos de animais, solos, subprodutos agroindustriais, tecidos animais e humanos, cabelos, ossos, unhas, plantas e vegetais, alimentos e dietas, amostras ambientais (IPEN, 2010). Apenas alguns materiais compostos por 
radioisótopos com tempo de meia vida física muito curta não são possíveis de ser quantificados pela AAN.

O Instituto de Pesquisas Energéticas e Nucleares (IPEN), órgão da Comissão Nacional de Energia Nuclear (CNEN), apresenta destacada atuação em vários setores da atividade nuclear entre elas, nas aplicações das radiações e radioisótopos, em reatores nucleares, em materiais e no ciclo do combustível, em radioproteção e dosimetria, cujos resultados vêm proporcionando avanços significativos no domínio de tecnologias, na produção de materiais e na prestação de serviços de valor econômico e estratégico para o país, possibilitando estender os benefícios da energia nuclear a segmentos maiores da população (IPEN, 2010).

Além disso, o IPEN-CNEN/SP, possui um reator nuclear de pesquisa, que hoje opera em 3,5 MW por 64 horas continuamente, que permite a produção de radioisótopos utilizados na produção de radiofármacos e na pesquisa, o que cumpre com as necessidades fundamentais para a realização da metodologia (Osso et al., 2009).

\subsubsection{Estudos farmacológicos com auxílio de um traçador radioativo}

A utilização de radiotraçadores, em estudos realizados em animais, tem mostrado papel potencial no desenvolvimento farmacológico, auxiliando na pesquisa e na determinação da farmacocinética de muitos fármacos (Meikle et al., 2001). Além disso, apresenta papel comprovado no preparo e registro de radiofármacos (ANVISA, 2009). A construção de lipossomas radiomarcados demonstra ser uma ferramenta ideal para a realização de estudos de biodistribuição de compostos, permite a avaliação do comportamento in vivo de lipossomas com diferentes composições lipídicas, o diagnóstico por imagem e estudos da terapia radionuclídica (Bao et al., 2003).

Para investigar o destino de lipossomas in vivo, uma grande variedade de marcadores lipossomais está disponível. A encapsulação de compostos hidrossolúveis radiomarcados ou a incorporação de lipídios marcados na bicamada lipídica fornecem uma ferramenta poderosa e sensível para determinar a biodistribuição do lipossoma. Os lipídios radiomarcados podem ser facilmente incorporados na bicamada lipídica misturados com outros lipídios durante a preparação dos lipossomas. É importante que o lipídio marcado seja estavelmente incorporado na bicamada lipídica do lipossoma para evitar a transferência do marcador da membrana lipossomal para as membranas celulares, como a membrana plasmática, a membrana endossomal ou aos componentes do soro como as 
lipoproteínas. Além disso, deve ser metabolicamente inerte, para evitar interpretações errôneas. São exemplos de marcadores radioativos que atendem essas características: éter de ${ }^{3}$ H-hexadecil colesterol ou ${ }^{3} \mathrm{H}$-oleato de colesterol (Kamps \& Scherphof, 2004).

A encapsulação de compostos hidrossolúveis radiomarcados pode aumentar a confiabilidade da avaliação da interação lipossoma-célula. No entanto, existem algumas desvantagens nesta abordagem devido à possibilidade de baixa eficiência de encapsulação, liberação espontânea e/ou induzida por célula do conteúdo encapsulado e a absorção do radiomarcador (não encapsulado) pelas células. Em geral, esses compostos devem ser facilmente detectáveis, altamente solúveis em água e não devem interagir com o ambiente hidrofóbico da bicamada lipídica ou com os grupos de cabeça polares dos constituintes lipídicos dos lipossomas. Devem ter relativamente baixo peso molecular para facilitar a separação entre os lipossomas e o material não encapsulado. Diferentes compostos radiomarcados foram utilizados para determinar a eficiência de encapsulação e o destino dos lipossomas in vitro e in vivo, tais como ${ }^{3} \mathrm{H}$-inulina $\mathrm{e}^{3} \mathrm{H}$-sacarose, agentes quimioterápicos, proteínas como lisozima e albumina (Schroit et al., 1986)

Alternativa que se mostra altamente viável é a utilização de compostos antimoniais radioemissores preparados por ativação neutrônica. Recentemente, Borborema e colaboradores demonstraram que a irradiação com nêutrons de antimoniato de meglumina no reator nuclear IEA-R1 (IPEN-CNEN-SP) resultou na produção de dois radiotraçadores isotópicos de antimônio: ${ }^{122} \mathrm{Sb}$ e ${ }^{124} \mathrm{Sb}$. O composto irradiado apresentou alta pureza radionuclídica, boa atividade específica e características fisiológicas adequadas para realização dos estudos de biodistribuição (Borborema et al., 2005 a, b). A utilização de radiotraçadores pela irradiação com nêutrons mostrou-se ser uma ferramenta interessante para esclarecer algumas características dos antimoniais. Esta abordagem apresenta-se bastante favorável, permitindo a realização de estudos de biodistribuição de diferentes compostos baseados em antimônio e também destes mesmos compostos encapsulados em lipossomas, além disso, demonstra ser um método rápido, reprodutível e menos trabalhoso, evitando o uso de substâncias necessárias para realizar a marcação do radionuclídeo ao lipossoma.

A produção dos isótopos radioativos de antimônio pode ser realizada através de uma reação nuclear provocada em um reator, onde ocorre o bombardeamento dos núcleos estáveis do produto com os nêutrons vindos do processo de fissão do Urânio-235 (combustível físsil). Os radioisótopos produzidos em reator nuclear apresentam-se instáveis por excesso de nêutrons e transformam um nêutron em um próton, assim 
desintegram-se preferencialmente por emissão de négatron e raios gama. $\mathrm{O}{ }^{122} \mathrm{Sb}$ decai 97,59 \% por emissão de $\beta^{-}$e 2,41 \% por emissão de captura eletrônica (EC) e $\beta^{+}$, gerando ${ }^{122}$ Te estável e ${ }^{122} \mathrm{Sn}$ estável, respectivamente (FIG. 08). O ${ }^{124} \mathrm{Sb}$ decai $100 \%$ por emissão de $\beta^{-}$, gerando ${ }^{124}$ Te estável (FIG. 09).
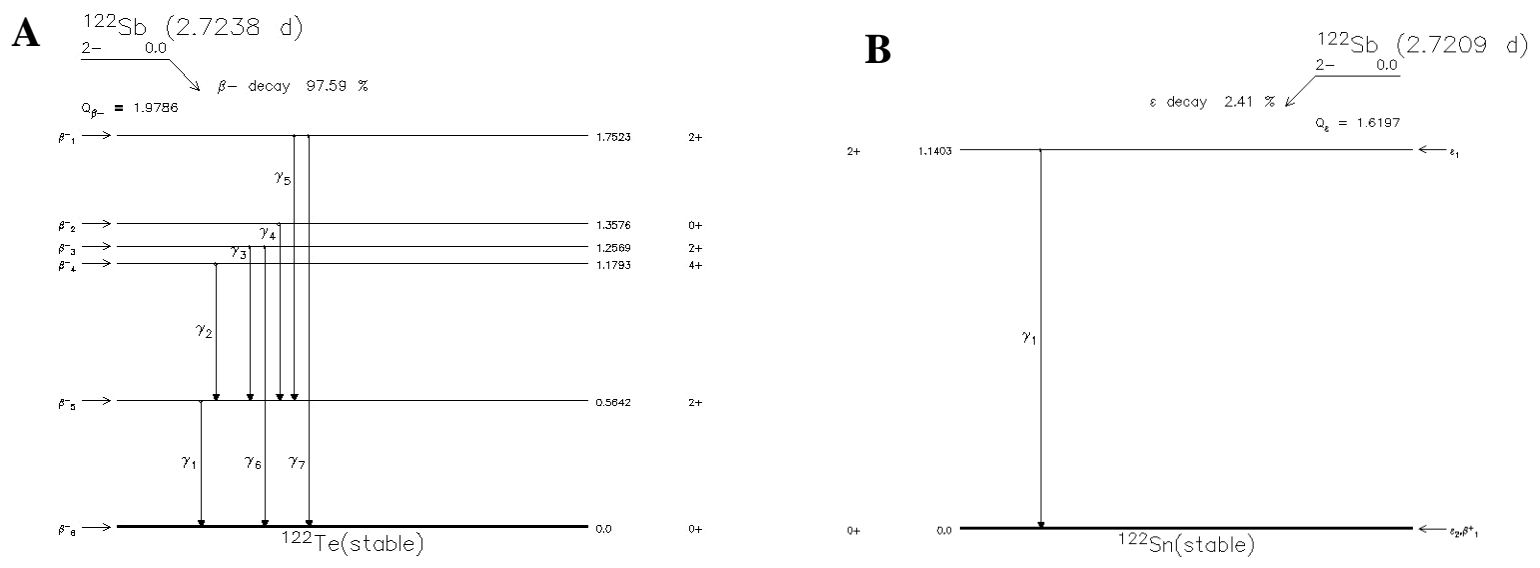

FIGURA 08 - Esquema simplificado de decaimento do ${ }^{122} \mathrm{Sb}$. A: por emissão de $\beta^{-}$; B: por captura eletrônica (EC).

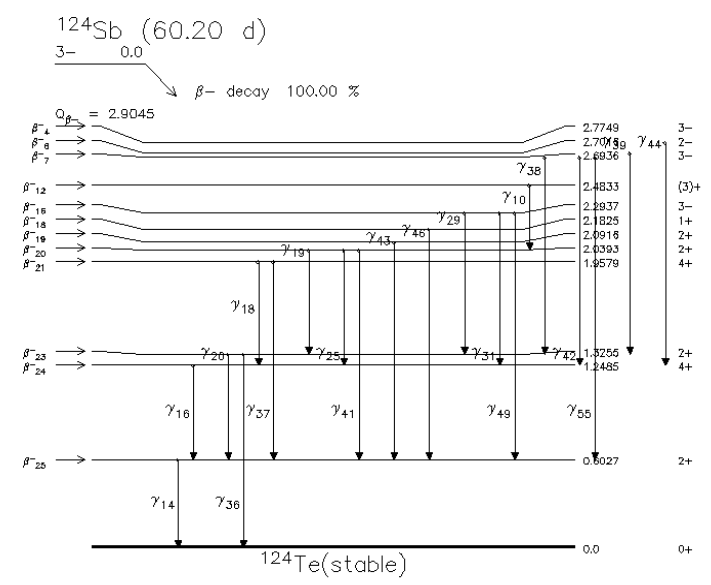

FIGURA 09 - Esquema simplificado de decaimento do ${ }^{124} \mathrm{Sb}$, por emissão de $\beta$.

Um traçador radioativo ou radioisótopo pode ser definido como uma pequena quantidade de um isótopo radioativo incorporado a um sistema, com a finalidade de definir seu percurso ou localização (Brownell et al., 1968). Têm diversas aplicações na medicina, indústria, agricultura e na proteção ao meio ambiente (CNEN, 2010), sendo um elemento ou substância que quando administrado em um ser vivo em quantidades mínimas, mantendo-se identificável e indiferenciável, pode reproduzir com fidelidade o 
comportamento do organismo sem, contudo influenciá-lo. Estudos utilizando os radioelementos e moléculas radiomarcadas mostram grande simplicidade no processo analítico (Brownell et al., 1968). Desta forma, o estudo farmacológico de muitos fármacos tem sido possível devido ao auxílio de traçadores isotópicos, representados por substâncias marcadas com átomos radioativos - radiofármacos (Neves et al., 2002). 


\section{OBJETIVOS}

O objetivo geral do trabalho foi desenvolver uma formulação de antimônio lipossomal, contendo fosfolipídios captados preferencialmente pelo sistema mononuclear fagocitário, à base de fosfatidilserina e estudar sua farmacocinética em animais sadios, para esclarecer o metabolismo e distribuição deste composto, visando à melhoria da terapia antileishmania.

Especificamente, pretendeu-se:

1. Desenvolver metodologias para determinar o antimônio em lipossomas;

2. Desenvolver formulações de antimônio lipossomal;

3. Caracterizar as propriedades físico-químicas das formulações lipossomais;

4. Analisar a citotoxicidade das diferentes formulações lipossomais em células macrofágicas em cultivo e em macrófago peritoneais;

5. Avaliar a atividade antileishmania das diferentes formulações lipossomais no tratamento in vitro de macrófagos infectados com Leishmania sp.;

6. Avaliar a localização e os mecanismos de captação dos lipossomas por microscopia de fluorescência;

7. Avaliar a radiomarcação de uma formulação lipossomal com o radioisótopo de ${ }^{122} \mathrm{Sb}$;

8. Determinar a pureza e eficiência da marcação do lipossoma com o radioisótopo;

9. Determinar a biodistribuição da formulação lipossomal radiomarcada em animais sadios, por método invasivo;

10. Avaliar a distribuição compartimental por modelos matemáticos. 


\section{MATERIAIS E MÉTODOS}

\subsection{Solventes, Soluções, Fármacos}

Todas as soluções utilizadas foram preparadas empregando-se reagentes de pureza analítica e água ultrapura obtida em sistema Milli-Q (Millipore, Bedford, MA, EUA).

\begin{tabular}{|c|c|c|c|}
\hline \multicolumn{4}{|c|}{ Solventes e Reagentes } \\
\hline Fórmula & Nome Químico & Massa Molecular & Marca \\
\hline $\mathrm{CH}_{3} \mathrm{OH}$ & Metanol & $32,04 \mathrm{~g} / \mathrm{mol}$ & $\begin{array}{l}\text { Merck KGaA, } \\
\text { Darmstadt, DE }\end{array}$ \\
\hline $\mathrm{CH}_{2} \mathrm{Cl}_{2}$ & Diclorometano & $84,93 \mathrm{~g} / \mathrm{mol}$ & $\begin{array}{l}\text { Merck KGaA, } \\
\text { Darmstadt, DE }\end{array}$ \\
\hline $\mathrm{CHCl}_{3}$ & Clorofórmio & $119,38 \mathrm{~g} / \mathrm{mol}$ & $\begin{array}{l}\text { Merck KGaA, } \\
\text { Darmstadt, DE }\end{array}$ \\
\hline $\mathrm{HCl}$ & Ácido Clorídrico & $36,50 \mathrm{~g} / \mathrm{mol}$ & $\begin{array}{l}\text { Merck KGaA, } \\
\text { Darmstadt, DE }\end{array}$ \\
\hline $\mathrm{HNO}_{3}$ & Ácido Nítrico & $63,00 \mathrm{~g} / \mathrm{mol}$ & $\begin{array}{l}\text { Merck KGaA, } \\
\text { Darmstadt, DE }\end{array}$ \\
\hline $\mathrm{C}_{3} \mathrm{H}_{8} \mathrm{O}_{3}$ & Glicerina & $92,09 \mathrm{~g} / \mathrm{mol}$ & $\begin{array}{l}\text { Merck KGaA, } \\
\text { Darmstadt, DE }\end{array}$ \\
\hline $\mathrm{KH}_{2} \mathrm{PO}_{4}$ & Diidrogenofosfato de potássico & $136,09 \mathrm{~g} / \mathrm{mol}$ & $\begin{array}{l}\text { Merck KGaA, } \\
\text { Darmstadt, DE }\end{array}$ \\
\hline $\mathrm{C}_{6} \mathrm{H}_{14} \mathrm{O}_{6}$ & D(-) Manitol & $187,17 \mathrm{~g} / \mathrm{mol}$ & $\begin{array}{l}\text { Merck KGaA, } \\
\text { Darmstadt, DE }\end{array}$ \\
\hline $\mathrm{Na}_{2} \mathrm{HPO}_{4} \cdot 2 \mathrm{H}_{2} \mathrm{O}$ & $\begin{array}{l}\text { Hidrogenofosfato de sódio } \\
\text { diidratado }\end{array}$ & $177,99 \mathrm{~g} / \mathrm{mol}$ & $\begin{array}{l}\text { Merck KGaA, } \\
\text { Darmstadt, DE }\end{array}$ \\
\hline $\mathrm{C}_{12} \mathrm{H}_{22} \mathrm{O}_{11}$ & $\mathrm{D}(+)$ Sacarose & $342,30 \mathrm{~g} / \mathrm{mol}$ & $\begin{array}{l}\text { Vetec Quimica, RJ, } \\
\text { BR }\end{array}$ \\
\hline \multicolumn{4}{|c|}{ Cultura Celular } \\
\hline \multicolumn{3}{|c|}{$\begin{array}{l}\text { OPTI-MEM }^{\circledR} \text { I Meio com redução de soro - modificação de MEM } \\
\text { (Eagle's) }\end{array}$} & $\begin{array}{l}\text { Gibco, Invitrogen } \\
\text { AG, Basel, CH }\end{array}$ \\
\hline \multicolumn{3}{|c|}{ RPMI 1640} & $\begin{array}{l}\text { Gibco, Invitrogen } \\
\text { AG, Basel, CH }\end{array}$ \\
\hline \multicolumn{3}{|c|}{ Meio Drosófila de Schneider (1X) } & $\begin{array}{l}\text { Gibco, Invitrogen } \\
\text { AG, Basel, CH }\end{array}$ \\
\hline \multicolumn{3}{|c|}{ Meio M199 com sal de Earle } & $\begin{array}{c}\text { Sigma, Saint Louis, } \\
\text { EUA }\end{array}$ \\
\hline \multicolumn{3}{|c|}{ Soro Fetal Bovino (SFB) } & $\begin{array}{c}\text { Gibco, Invitrogen } \\
\text { AG, Basel, CH }\end{array}$ \\
\hline \multicolumn{3}{|c|}{$\begin{array}{l}\text { Solução de Penicilina-Estreptomicina com } 10000 \mathrm{U} / \mathrm{mL} \text { e } 10000 \\
\mu \mathrm{g} / \mathrm{mL}\end{array}$} & $\begin{array}{l}\text { Gibco, Invitrogen } \\
\text { AG, Basel, CH }\end{array}$ \\
\hline
\end{tabular}




\begin{tabular}{|c|c|c|c|}
\hline $\mathrm{C}_{34} \mathrm{H}_{32} \mathrm{ClFeN}_{4} \mathrm{O}_{4}$ & $\begin{array}{c}\text { Ácido propiônico 3-[18-(2- } \\
\text { carboxietil)-8,13-di(etenil)- } \\
\text { 3,7,12,17-tetrametilporpirina- } \\
\text { 21,24-diid-2-il] (Hemina) }\end{array}$ & $651.95 \mathrm{~g} / \mathrm{mol}$ & \\
\hline $\mathrm{C}_{8} \mathrm{H}_{18} \mathrm{~N}_{2} \mathrm{O}_{4} \mathrm{~S}$ & $\begin{array}{c}\text { Ácido N-2- } \\
\text { hidroxietilpiperazina-N'-2'- } \\
\text { Etanossulfônico (HEPES) }\end{array}$ & $238,30 \mathrm{~g} / \mathrm{mol}$ & $\begin{array}{c}\text { Sigma, Saint Louis, } \\
\text { EUA }\end{array}$ \\
\hline $\mathrm{NaHCO}_{3}$ & Bicarbonato de Sódio & $84,00 \mathrm{~g} / \mathrm{mol}$ & $\begin{array}{c}\text { Sigma, Saint Louis, } \\
\text { EUA }\end{array}$ \\
\hline $\mathrm{C}_{3} \mathrm{H}_{3} \mathrm{NaO}_{3}$ & Piruvato de Sódio & $110,04 \mathrm{~g} / \mathrm{mol}$ & $\begin{array}{c}\text { Gibco, Invitrogen } \\
\text { AG, Basel, CH }\end{array}$ \\
\hline $\mathrm{C}_{18} \mathrm{H}_{16} \mathrm{BrN}_{5} \mathrm{~S}$ & $\begin{array}{c}\text { Brometo Tetrazólico Azul 3- } \\
\text { (4,5-dimetiltiazol-2-il)-2,5- } \\
\text { difenil brometo tetrazólico } \\
\left(\mathrm{C}_{18} \mathrm{H}_{16} \mathrm{BrN}_{5} \mathrm{~S}\right) \text {-MTT }\end{array}$ & $414,30 \mathrm{~g} / \mathrm{mol}$ & $\begin{array}{c}\text { Sigma, Saint Louis, } \\
\text { EUA }\end{array}$ \\
\hline $\mathrm{C}_{12} \mathrm{H}_{6} \mathrm{NNaO}_{4}$ & $\begin{array}{l}\text { Sal de Sódio de Resazurina (7- } \\
\text { Hidroxi-3H-fenoxazina-3-ona } \\
\text { 10-óxido) }\end{array}$ & $251,17 \mathrm{~g} / \mathrm{mol}$ & $\begin{array}{c}\text { Sigma, Saint Louis, } \\
\text { EUA }\end{array}$ \\
\hline $\mathrm{C}_{12} \mathrm{H}_{25} \mathrm{NaO}_{4} \mathrm{~S}$ & Dodecil Sulfato de Sódio (SDS) & $288,38 \mathrm{~g} / \mathrm{mol}$ & $\begin{array}{c}\text { Sigma, Saint Louis, } \\
\text { EUA }\end{array}$ \\
\hline $\mathrm{C}_{14} \mathrm{H}_{14} \mathrm{ClN}_{3} \mathrm{~S}$ & Giemsa - corante & $291,80 \mathrm{~g} / \mathrm{mol}$ & $\begin{array}{c}\text { Sigma, Saint Louis, } \\
\text { EUA }\end{array}$ \\
\hline \multicolumn{4}{|c|}{ Preparação de Lipossomas } \\
\hline Fórmula & Nome Químico & Massa Molecular & Marca \\
\hline $\mathrm{C}_{42} \mathrm{H}_{80} \mathrm{NO}_{8} \mathrm{P}$ & Fosfatidilcolina de Soja & $770,00 \mathrm{~g} / \mathrm{mol}$ & $\begin{array}{c}\text { L.Meyer, Hamburg, } \\
\text { DE }\end{array}$ \\
\hline $\mathrm{C}_{42} \mathrm{H}_{84} \mathrm{NO}_{8} \mathrm{P}$ & $\begin{array}{c}\text { Fosfatidilcolina Hidrogenada de } \\
\text { Ovo }\end{array}$ & $779,00 \mathrm{~g} / \mathrm{mol}$ & $\begin{array}{c}\text { Lipoid GmbH, } \\
\text { Ludwigshafen, DE }\end{array}$ \\
\hline $\mathrm{C}_{40} \mathrm{H}_{73} \mathrm{NNaO}_{10} \mathrm{P}$ & $\begin{array}{c}\text { Fosfatidilserina Hidrogenada de } \\
\text { Ovo }\end{array}$ & $804,50 \mathrm{~g} / \mathrm{mol}$ & $\begin{array}{c}\text { Lipoid GmbH, } \\
\text { Ludwigshafen, DE }\end{array}$ \\
\hline $\mathrm{C}_{42} \mathrm{H}_{79} \mathrm{NNa} \mathrm{O}{ }_{10} \mathrm{P}$ & $\begin{array}{c}\text { Fosfatidilserina de Cérebro } \\
\text { Bovino (3-sn-fosfatildil-L- } \\
\text { serina) }\end{array}$ & $760,00 \mathrm{~g} / \mathrm{mol}$ & $\begin{array}{c}\text { Sigma, Saint Louis, } \\
\text { EUA }\end{array}$ \\
\hline $\mathrm{C}_{40} \mathrm{H}_{73} \mathrm{NNaO}_{10} \mathrm{P}$ & $\begin{array}{l}\text { Fosfatidilserina de Soja (L- } \alpha- \\
\text { fosfatildilserina) }\end{array}$ & $781,98 \mathrm{~g} / \mathrm{mol}$ & $\begin{array}{l}\text { Avanti Polar Lipids, } \\
\text { Inc. Alabama, EUA }\end{array}$ \\
\hline $\mathrm{C}_{27} \mathrm{H}_{46} \mathrm{O}$ & Colesterol & $386,66 \mathrm{~g} / \mathrm{mol}$ & Fluka, Buchs, $\mathrm{CH}$ \\
\hline $\mathrm{C}_{29} \mathrm{H}_{50} \mathrm{O}_{2}$ & D,L $\alpha$-Tocoferol & $431,00 \mathrm{~g} / \mathrm{mol}$ & $\begin{array}{l}\text { Merck KGaA, } \\
\text { Darmstadt, DE }\end{array}$ \\
\hline $\mathrm{C}_{59} \mathrm{H}_{97} \mathrm{ClN}_{2} \mathrm{O}_{4}$ & $\begin{array}{c}\text { Perclorato } 1,1 \text { '-dioctadecil- } \\
\text { 3,3,3',3'- } \\
\text { tetrametilindocarbocianina - } \\
\text { DilC }_{18}(3)\end{array}$ & $933,88 \mathrm{~g} / \mathrm{mol}$ & $\begin{array}{l}\text { Molecular Probes, } \\
\text { Invitrogen, EUA }\end{array}$ \\
\hline \multicolumn{4}{|c|}{ Fármaco } \\
\hline & Antimoniato de Meglumina & $366,00 \mathrm{~g} / \mathrm{mol}$ & Aventis Pharma,BR \\
\hline \multicolumn{4}{|c|}{ Microscopia Eletrônica de Transmissão } \\
\hline $\mathrm{H}_{3} \mathrm{O}_{40} \mathrm{PW}_{12} \cdot \mathrm{H}_{2} \mathrm{O}$ & \begin{tabular}{|l|l} 
Ácido Fosfotúngstico & \\
\end{tabular} & $2880 \mathrm{~g} / \mathrm{mol}$ & Vetec Quimica, BR \\
\hline \multicolumn{4}{|c|}{ Microscopia de Fluorescência } \\
\hline $\mathrm{CH}_{2} \mathrm{O}$ & Formaldeído $10 \%$ & $30,03 \mathrm{~g} / \mathrm{mol}$ & $\begin{array}{l}\text { AppliChem GmbH, } \\
\text { Darmstadt, DE }\end{array}$ \\
\hline
\end{tabular}




\begin{tabular}{|c|c|c|c|}
\hline $\mathrm{C}_{16} \mathrm{H}_{15} \mathrm{~N}_{5} \cdot 2 \mathrm{HCl}$ & $\begin{array}{l}\text { 4'-6-Diamidino-2-fenilindola } \\
\text { (DAPI) }\end{array}$ & $350,30 \mathrm{~g} / \mathrm{mol}$ & $\begin{array}{l}\text { Roche Diagnostics } \\
\text { GmbH, Mannheim, } \\
\text { DE }\end{array}$ \\
\hline \multicolumn{4}{|c|}{ Determinação de Fosfolipídios } \\
\hline $\mathrm{NH}_{4} \mathrm{SCN}$ & Tiocianato de Amônio & $76,12 \mathrm{~g} / \mathrm{mol}$ & $\begin{array}{l}\text { Merck KGaA, } \\
\text { Darmstadt, DE }\end{array}$ \\
\hline $\mathrm{FeCl}_{3}$ & Cloreto Férrico Hexaidratado & $270,32 \mathrm{~g} / \mathrm{mol}$ & $\begin{array}{l}\text { Merck KGaA, } \\
\text { Darmstadt, DE }\end{array}$ \\
\hline \multicolumn{4}{|c|}{ Determinação de Antimônio } \\
\hline $\begin{array}{c}\mathrm{C}_{4} \mathrm{H}_{4} \mathrm{O}_{7} \mathrm{KSb} .3 \\
\mathrm{H}_{2} \mathrm{O}\end{array}$ & $\begin{array}{c}\text { Tartarato de Antimônio e } \\
\text { Potássio Triidratado - Sb(III) }\end{array}$ & $667,87 \mathrm{~g} / \mathrm{mol}$ & Fluka, Buchs, CH \\
\hline $\begin{array}{c}\mathrm{C}_{4} \mathrm{H}_{4} \mathrm{O}_{7} \mathrm{KSb} .1 / 2 \\
\mathrm{H}_{2} \mathrm{O} \\
\end{array}$ & $\begin{array}{l}\text { Tartarato de Antimônio e } \\
\text { Potássio - Sb(III) }\end{array}$ & $333,93 \mathrm{~g} / \mathrm{mol}$ & $\begin{array}{l}\text { Merck KGaA, } \\
\text { Darmstadt, DE }\end{array}$ \\
\hline $\mathrm{KSb}(\mathrm{OH})_{6}$ & $\begin{array}{l}\text { Hexaidroxiantimonato de } \\
\text { Potássio }(\mathrm{V})-\mathrm{Sb}(\mathrm{V})\end{array}$ & $262,90 \mathrm{~g} / \mathrm{mol}$ & $\begin{array}{c}\text { Sigma, Saint Louis, } \\
\text { EUA }\end{array}$ \\
\hline $\mathrm{KIO}_{3}$ & Iodato de Potássio & $214,00 \mathrm{~g} / \mathrm{mol}$ & $\begin{array}{c}\text { Sigma, Saint Louis, } \\
\text { EUA }\end{array}$ \\
\hline $\mathrm{KI}$ & Iodeto de Potássio & $166,00 \mathrm{~g} / \mathrm{mol}$ & Fluka, Buchs, CH \\
\hline $\mathrm{C}_{25} \mathrm{H}_{31} \mathrm{~N}_{3}$ & $\begin{array}{c}\text { Leucocristal de Violeta }\left(4,4^{\prime}, 4^{\prime \prime}-\right. \\
\text { metildinetris (N, N'- } \\
\text { dimetilanilina) }\end{array}$ & $373,54 \mathrm{~g} / \mathrm{mol}$ & $\begin{array}{c}\text { Sigma, Saint Louis, } \\
\text { EUA }\end{array}$ \\
\hline $\mathrm{NaOH}$ & Hidróxido de Sódio & $40,00 \mathrm{~g} / \mathrm{mol}$ & $\begin{array}{l}\text { AppliChem GmbH, } \\
\text { Darmstadt, DE }\end{array}$ \\
\hline $\mathrm{H}_{3} \mathrm{PO}_{4}$ & Ácido fosfórico & $98,00 \mathrm{~g} / \mathrm{mol}$ & $\begin{array}{l}\text { Merck KGaA, } \\
\text { Darmstadt, DE }\end{array}$ \\
\hline $\mathrm{C}_{6} \mathrm{H}_{8} \mathrm{O}_{6}$ & Ácido ascórbico & $176,13 \mathrm{~g} / \mathrm{mol}$ & $\begin{array}{l}\text { Merck KGaA, } \\
\text { Darmstadt, DE }\end{array}$ \\
\hline $\mathrm{Sb}_{2} \mathrm{O}_{3}$ & $\begin{array}{c}\text { Solução padrão de antimônio } \\
\text { para ICP }-\mathrm{Sb}_{2} \mathrm{O}_{3} \mathrm{em} \mathrm{HCl} 7 \% \\
1000 \mathrm{mg} / 1\end{array}$ & & $\begin{array}{l}\text { Merck KGaA, } \\
\text { Darmstadt, DE }\end{array}$ \\
\hline
\end{tabular}

\subsection{Infraestutura}

A parte experimental da pesquisa do presente trabalho foi desenvolvida por uma equipe multidisciplinar. Os estudos de biodistribuição foram realizados nos laboratórios do Centro de Biotecnologia (CB) do IPEN-CNEN/SP, sob a coordenação da Prof ${ }^{a}$ Dra. Nanci do Nascimento. A ativação neutrônica foi feita no Reator Nuclear de Pesquisa IEA-R1 do Centro do Reator de Pesquisas (CRPq) do IPEN-CNEN/SP. A marcação das formulações lipossomais e as determinações de antimônio ocorreram nos laboratórios da Diretoria de Radiofarmácia (DIRF) do IPEN-CNEN/SP, sob a coordenação do Prof ${ }^{\circ}$ Dr. João Alberto Osso Junior. A produção dos lipossomas e os estudos biológicos in vitro foram executados no Laboratório de Protozoologia do Instituto de Medicina Tropical de São Paulo (IMTSP/FM-USP), sob a supervisão do Prof ${ }^{\circ}$ Dr. Heitor Franco de 
Andrade Junior e também foram executados no Laboratório de Pesquisas em Lipossomas do Instituto de Pesquisas Molecular do Câncer (IMCR- UZ/Suiça), sob a supervisão do Prof $f^{o}$ Dr. Reto Albert Schwendener. A determinação de antimônio por Voltametria foi realizada no Instituto de Ecologia Terrestre - Proteção do Solo (ETH - Zurique - Suíça).

\subsubsection{Equipamentos, Utensílios e Softwares}

\begin{tabular}{|c|c|}
\hline Lipex $^{\mathrm{TM}}$ Extrusor & $\begin{array}{l}\text { Lipex Biomembranes Inc. } \\
\text { Vancouver, CA }\end{array}$ \\
\hline Conjunto Extrusor e Estabilizador LiposoFast & Avestin Inc, Ontario CA \\
\hline Liofilizador -EC Modulyo & Edwards Brasil Ltda, SP, BR \\
\hline Evaporador Rotativo & Rotavap Instrument, Büchi,CH \\
\hline Evaporador Rotativo & Fisatom Ltda, São Paulo, BR \\
\hline $\begin{array}{l}\text { Determinador de Partículas por Espalhamento Dinâmico } \\
\text { de Luz Laser-Nicomp } 370\end{array}$ & Nicomp, Santa Barbara, EUA \\
\hline $\begin{array}{l}\text { Membranas de Policarbonato, Nucleopore }{ }^{\mathrm{TM}} \text { - diâmetro } \\
\text { do poro } 0,4 \mu \mathrm{m} \text { e } 0,1 \mu \mathrm{m}\end{array}$ & Sterico, Dietikon, $\mathrm{CH}$ \\
\hline Membranas de Policarbonato - diâmetro do poro $0,2 \mu \mathrm{m}$ & Avestin Inc, Ontario CA \\
\hline Tubo de Celulose para Diálise & $\begin{array}{l}\text { Sigma-Aldrich Brasil Ltda, } \\
\text { São Paulo, BR }\end{array}$ \\
\hline $\begin{array}{l}\text { Membrana PVDF, Millex HV - diâmetro do poro } \\
0,45 \mu \mathrm{m} \text { e } 0,22 \mu \mathrm{m}\end{array}$ & Millipore, EUA \\
\hline \multicolumn{2}{|c|}{ Microscópio de Fluorescência, Olympus Biosystem IX81 Olympus, Japão } \\
\hline Microscópio DM-RB Leica & Leica Microsystems, $\mathrm{CH}$ \\
\hline Microscópio de Transmissão Eletrônica - JEOL-1010 & JEOL Ltda, Tóquio, Japão \\
\hline Citômetro de Fluxo de Alta Desempenho CyAn ${ }^{\mathrm{TM}}$ ADP & Dako Inc, CA, EUA \\
\hline $\begin{array}{l}\text { Espectrofluorímetro - SpectraMax M5/M5 }{ }^{\mathrm{e}} \text { Microplate } \\
\text { Reader }\end{array}$ & Molecular Devices, CA, EUA \\
\hline $\begin{array}{l}\text { Espectrofotômetro - Thermo Labsystems Multiskan } \\
\text { Ascent } 354\end{array}$ & Thermo Labsystems, EUA \\
\hline Potenciostato - 797 VA Computrace. & Metrohm Ltd., Herisau, CH \\
\hline ICP-OES CCD Simultaneous, Vista - MPX & Varian Inc., CA, EUA \\
\hline Detector de Germânio Hiper Puro (HPGe) & $\begin{array}{l}\text { Canberra Industries Inc., } \\
\text { Meriden, EUA }\end{array}$ \\
\hline Genie-PC Neutron Assay Software Model S430 & Canberra Industries Inc., EUA \\
\hline Cell R Software & Olympus, Japão \\
\hline Graph Pad Prism 5.02 & $\begin{array}{l}\text { GraphPad Software Inc., La } \\
\text { Jolla, EUA }\end{array}$ \\
\hline Software 797 VA Computrace Software 1.3. & Metrohm AG, Herisau, CH \\
\hline
\end{tabular}




\subsection{Experimentos}

\subsubsection{Lipossomas}

\subsubsection{Preparação de Diferentes Formulações de Antimônio Lipossomal}

\subsection{Lipossomas por sonicação seguido de extrusão através de membrana de policarbonato (FEL)}

Os lipossomas produzidos pelo método da hidratação do filme lipídico seguido por sonicação e extrusão através de membrana de policarbonato (FEL) (FIG. 10) foram preparados como descrito por Tempone et al., 2004. Foi utilizada uma mistura de lipídios como fosfatidilcolina de ovo hidrogenada (FCO), fosfatidilserina de ovo hidrogenada (FSO) e colesterol (Col), na razão molar de 5:1:4 (111 mg) (TAB. 05), diluídos em solução orgânica de clorofórmio/metanol (2:1, v/v) e evaporada sob vácuo a $55^{\circ} \mathrm{C}$ em um evaporador rotativo. $\mathrm{O}$ filme lipídico foi hidratado com $1 \mathrm{~mL}$ do agente antimonial (AM ou $\mathrm{Sb}(\mathrm{III})$ ) previamente aquecido, permanecendo em rotação por 50 minutos a $55^{\circ} \mathrm{C}$. Após, a solução foi sonicada em banho de sonicação a $55^{\circ} \mathrm{C}$ por 10 minutos. Posteriormente, foi realizada a extrusão através de membrana de policarbonato com poros de $0,2 \mu \mathrm{m}$ por $17 \mathrm{x}$, utilizando um mini-extrusor Liposofast. A separação do fármaco não encapsulado foi realizada através de diálise em solução isotônica de glicerol, num fator de diluição de 1000 $\mathrm{x}$, utilizando um agitador magnético, por 24 horas a $4{ }^{\circ} \mathrm{C}$. Ao final, os lipossomas foram armazenados a $4{ }^{\circ} \mathrm{C}$ até o momento de uso. $\mathrm{O}$ mesmo procedimento foi realizado para a obtenção de lipossomas controle (sem antimônio).

TABELA 05 - Composição de lipídios e fármaco usados na preparação dos lipossomas FEL.

\begin{tabular}{ccc}
\hline \multirow{2}{*}{ Compostos } & AM-FEL & FEL \\
\cline { 2 - 3 } & Conc $(\mathrm{mg} / \mathrm{mL})$ & Conc $(\mathrm{mg} / \mathrm{mL})$ \\
\hline FCO & 70 & 70 \\
FSO & 14 & 14 \\
Col & 27 & 27 \\
AM & 81 & - \\
\hline
\end{tabular}




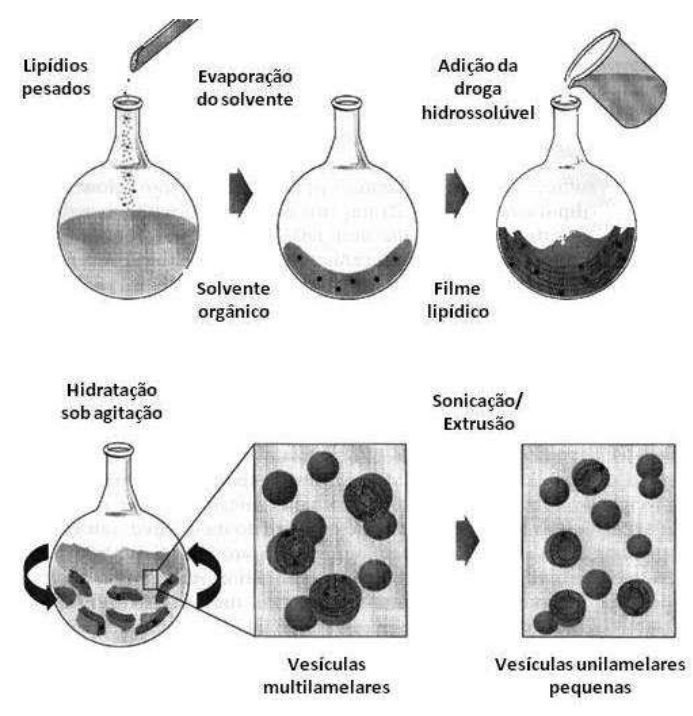

FIGURA 10 - Esquema do método de preparação de lipossomas do tipo FEL, baseado no processo de hidratação do filme lipídico.

\subsection{Lipossomas pequenos vazios liofilizados (FDEL)}

A elaboração de lipossomas pelo método da liofilização de lipossomas pequenos vazios com posterior reidratação do liofilizado (FDEL) (FIG. 11) foi realizada como descrito por Schettini et al., 2006. Foi utilizado uma mistura de lipídios como fosfatidilcolina de ovo hidrogenada (FCO), fosfatidilserina de ovo hidrogenada (FSO) e colesterol (Col), na razão molar de 5:1:4 (111 mg) (TAB. 06), diluídos em solução orgânica de clorofórmio/metanol $\left(2: 1\right.$, v/v) e evaporada sob vácuo a $55^{\circ} \mathrm{C}$ em um evaporador rotativo. O filme lipídico foi hidratado com $2 \mathrm{~mL}$ de solução isotônica de glicerol previamente aquecida, permanecendo em rotação por 50 minutos a $55^{\circ} \mathrm{C}$. Após, a solução foi sonicada em banho de sonicação a $55^{\circ} \mathrm{C}$ por 10 minutos. A solução foi esterilizada em um filtro com membrana de policarbonato com poros de 0,22 $\mu \mathrm{m}$. Foi adicionado solução de sacarose numa razão de massa de 3:1 açúcar/lipídio, com uma concentração final de açúcar de $0,3 \mathrm{~mol} \mathrm{~L}^{-1}$, usado como crioprotetor para a solução de lipossomas. A mistura resultante foi congelada a $-80{ }^{\circ} \mathrm{C}$ por 18 horas e subsequentemente liofilizada. A reidratação do liofilizado foi realizada pela adição de solução aquosa de agente antimonial, da seguinte maneira: foi adicionado $40 \%$ do volume original das vesículas (SUV) de solução de antimônio (64 mg $\mathrm{Sb}(\mathrm{V})$ ) ao pó liofilizado e a mistura permaneceu em rotação por 30 minutos a $55^{\circ} \mathrm{C}$; o mesmo volume de solução isotônica de glicerol foi adicionado e a mistura permaneceu em rotação por 30 minutos a $55{ }^{\circ} \mathrm{C}$; finalmente $120 \%$ do volume original das vesículas de solução isotônica de glicerol foi 
adicionado a mistura. A separação do fármaco não encapsulado foi realizada através de centrifugação (3 lavagens em 14000 x g, 30 minutos). Ao final, os lipossomas foram armazenados a $4{ }^{\circ} \mathrm{C}$ até o momento de uso. $\mathrm{O}$ mesmo procedimento foi realizado para a obtenção de lipossomas controle (sem antimônio).

TABELA 06 - Composição de lipídios e fármaco usados na preparação dos lipossomas FDEL.

\begin{tabular}{ccc}
\hline \multirow{2}{*}{ Compostos } & AM-FDEL & FDEL \\
\cline { 2 - 3 } & Conc $(\mathrm{mg} / \mathrm{mL})$ & Conc $(\mathrm{mg} / \mathrm{mL})$ \\
\hline FCO & 70 & 70 \\
FSO & 14 & 14 \\
Col & 27 & 27 \\
AM & 64 & - \\
\hline
\end{tabular}
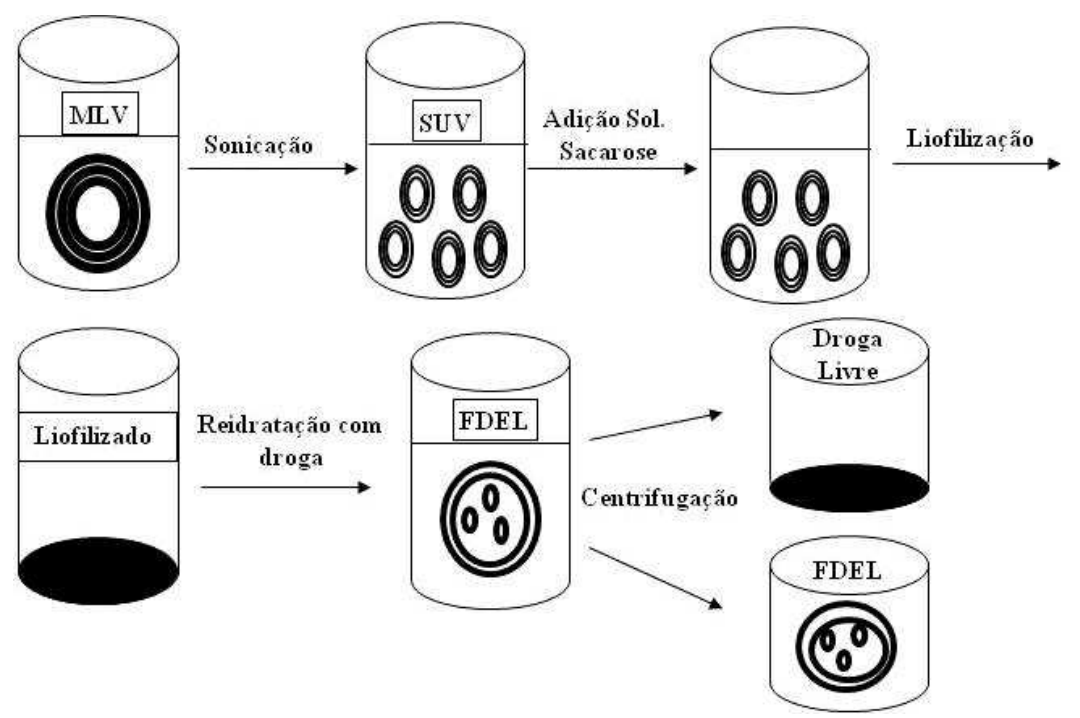

FIGURA 11 - Esquema do método de preparação de lipossomas do tipo FDEL, baseado no processo de hidratação do filme lipídico.

\subsection{Lipossomas por congelamento-descongelamento seguido de extrusão através de membrana de policarbonato usando alta pressão (FTL)}

Os lipossomas produzidos pelo método da hidratação do filme lipídico seguido por congelamento-descongelamento e extrusão através de membrana de policarbonato usando alta pressão (FTL) foram elaborados como descrito por Zeisberger et al., 2006. A mistura de lipídios como fosfatidilcolina (FC), fosfatidilserina de soja (FS) e colesterol (Col) e $\alpha$-tocoferol ( $\alpha$-Toc), na razão molar de 10:1:4:0,1 (TAB. 07), foi dissolvida em uma 
mistura de solvente orgânico de diclorometano/metanol (1:1, v/v) e evaporada sob vácuo a $40{ }^{\circ} \mathrm{C}$ em um evaporador rotativo. O filme lipídico seco foi disperso em uma solução fisiológica de fosfato $(20 \mathrm{mM}, \mathrm{pH} 7,4)$ suplementado com agente antimonial e manitol (230 mM), como crioprotetor permitindo o congelamento dos lipossomas. A solução resultante foi congelada em nitrogênio líquido e descongelada em água a $40{ }^{\circ} \mathrm{C}$ por 3 ciclos consecutivos. Posteriormente, foi realizada a extrusão através de membranas de policarbonato com poros de $0,4 \mu \mathrm{m}$ por $5 \mathrm{x}$, seguida de extrusão repetitiva $(8 \mathrm{x}) \mathrm{em}$ membranas com poros de $0,1 \mu \mathrm{m}$, usando um extrusor com alta pressão Lipex $^{\mathrm{TM}}$. A separação do fármaco não encapsulado foi realizada através de diálise em solução fisiológica de fosfato-manitol, num fator de diluição de $100 \mathrm{x}$, utilizando um agitador magnético, por 24 horas a $4{ }^{\circ} \mathrm{C}$. A preparação estéril de lipossomas foi obtida pela filtração através de membranas de policarbonato de $0,45 \mu \mathrm{m}$. Alíquotas foram armazenadas em -80 ${ }^{\circ} \mathrm{C}$ até o momento de uso. O mesmo procedimento foi realizado para obter lipossomas controle (sem antimônio). Todos os procedimentos realizados com este lipossoma foram conduzidos na Universidade de Zurique (Suíça), sob a coordenação do Prof. Dr. Reto A. Schwendener.

TABELA 07 - Composição de lipídios e fármaco usados na preparação dos lipossomas FTL.

\begin{tabular}{ccccc}
\hline \multirow{2}{*}{ Compostos } & AM-FTL & FTL & AM-PS-FTL & PS-FTL \\
\cline { 2 - 5 } & Conc $(\mathrm{mg} / \mathrm{mL})$ & Conc $(\mathrm{mg} / \mathrm{mL})$ & Conc $(\mathrm{mg} / \mathrm{mL})$ & Conc $(\mathrm{mg} / \mathrm{mL})$ \\
\hline FCS & 200 & 100 & 200 & 100 \\
FS & - & - & 20 & 10 \\
Col & 40 & 20 & 40 & 20 \\
$\alpha$-Toc & 1,12 & 0,56 & 1,12 & 0,56 \\
AM & 10,4 & - & 10,4 & - \\
\hline
\end{tabular}

\subsubsection{Preparação de Lipossoma Marcado com Corante Fluorescente (Dil-FTL)}

Os lipossomas fluorescentes foram preparados como descrito por Marty et al., 2004. Foi utilizado o método de elaboração de lipossomas FTL como descrito anteriormente, adicionando um corante lipofilico fluorescente - perclorato de dioctadecil tetrametilindocarbocianina $\left(\operatorname{DilC}_{18}(3)\right)$, na razão molar de 2:100 em referência a fosfatidilcolina de soja (TAB. 08), na mistura inicial de lipídios. 
TABELA 08 - Composição de lipídios e fármaco usados na preparação dos lipossomas fluorescentes (Dil-FTL).

\begin{tabular}{cccc}
\hline \multirow{2}{*}{ Compostos } & Dil-FTL & Dil-PS-FTL & Dil-AM-FTL \\
\cline { 2 - 4 } & Conc $(\mathrm{mg} / \mathrm{mL})$ & Conc $(\mathrm{mg} / \mathrm{mL})$ & Conc $(\mathrm{mg} / \mathrm{mL})$ \\
\hline FCS & 100 & 100 & 100 \\
FS & - & 10 & - \\
Col & 20 & 20 & 20 \\
$\alpha-$ Toc & 0,56 & 0,56 & 0,56 \\
Dil & 2 & 2 & 2 \\
AM & - & - & 10,4 \\
\hline
\end{tabular}

\subsubsection{Preparação de Lipossoma Radiomarcado (FDEL-AMI)}

Os lipossomas radiomarcados foram preparados pelo método de elaboração de lipossomas FDEL como descrito anteriormente. A reidratação do liofilizado foi realizada pela adição de solução aquosa de antimoniato de meglumina irradiado (AMI), como apresentado no subitem 3.3.3.5. A separação do fármaco não encapsulado foi realizada através de diálise em solução isotônica de glicerol, num fator de diluição de 1000 x, utilizando um agitador magnético, por 24 horas a $4{ }^{\circ} \mathrm{C}$. Ao final, os lipossomas foram armazenados a $4{ }^{\circ} \mathrm{C}$ até o momento de uso.

\subsubsection{Caracterização dos Lipossomas}

\subsubsection{Quantificação de fosfolipídios}

A quantificação dos fosfolipídios foi realizada pelo ensaio colorimétrico de Stewart (1980). A determinação foi realizada em amostras de lipossomas em tubo de ensaio, seguido da adição de $2 \mathrm{~mL}$ de clorofórmio e $2 \mathrm{~mL}$ da solução de Stewart $(27,03 \mathrm{~g}$ $\mathrm{NH}_{4} \mathrm{SCN}$ e 30,4 $\mathrm{g} \mathrm{FeCl}_{3} \cdot 6 \mathrm{H}_{2} \mathrm{O}$ em água bidestilada qsp $1000 \mathrm{~mL}$ ). Após agitação, foi feita a leitura da fase orgânica em espectrofotômetro a $485 \mathrm{~nm}$. Foi feita uma curva padrão com os dois fosfolipídios usados na produção dos lipossomas. Os resultados foram analisados por uma curva de regressão linear utilizando o software de estatística Graph Pad Prism 5.02 . 


\subsubsection{Determinação do tamanho dos lipossomas}

A determinação do diâmetro médio, da homogeneidade e da estabilidade dos lipossomas produzidos pelo método FEL e FDEL foi realizada através de técnica de microscopia eletrônica de transmissão. Uma alíquota do material foi fixada em tela de microscopia previamente preparada e corada negativamente com uma solução de ácido fosfotúngstico $1 \%(\mathrm{~m} / \mathrm{v})$ por 2 minutos, o material foi seco em temperatura ambiente e examinado em um microscópio eletrônico de transmissão (JEOL).

A determinação do diâmetro médio, da homogeneidade e da estabilidade dos lipossomas produzidos pelo método FTL foi realizada usando um determinador de tamanho de partículas por espalhamento dinâmico de luz laser (Nicomp), através da diluição da amostra com solução tampão de fosfato-manitol 1:500 (v/v).

\subsubsection{Determinação da eficiência de encapsulação (Ee)}

A eficiência de encapsulação (Ee) foi determinada pela quantidade de antimônio na solução lipossomal antes e depois da separação do fármaco não encapsulado. Os valores foram calculados como porcentagem de antimônio encapsulado no lipossoma, como descrito na fórmula (2) a seguir:

Eficiência de encapsulação (\%): ( $\left(\mathrm{Sb}_{\text {encapsulado }} / \mathrm{Sb}_{\text {total }}\right)$ x 100

Onde:

$\mathrm{Sb}_{\text {total }}=$ quantidade de antimônio na solução lipossomal antes da separação;

$\mathrm{Sb}_{\text {encapsulado }}=$ quantidade de antimônio na solução lipossomal depois da separação.

\subsubsection{Determinação da estabilidade das formulações lipossomais}

A estabilidade in vitro das formulações foi avaliada pelo monitoramento da retenção de antimônio nos lipossomas. Após a purificação por centrifugação das formulações lipossomais, dois estudos foram realizados: (1) as formulações de antimônio lipossomal foram incubadas em solução isotônica de glicerol a $4{ }^{\circ} \mathrm{C}$ por até 120 minutos; (2) as formulações de antimônio lipossomal foram incubadas em plasma de hamster a 37 
${ }^{\circ} \mathrm{C}$ por até 120 minutos. Depois de decorrido os tempos de incubação e imediatamente antes do processo de centrifugação, alíquotas das formulações incubadas foram removidas e acondicionadas em um tubo para a determinação de antimônio por AAN. Posteriormente, as soluções incubadas foram centrifugadas (14000 x g, 30 minutos) e foi transferida uma alíquota do sobrenadante e do precipitado para um tubo para a determinação de antimônio por AAN.

\subsubsection{Determinação de Antimônio Total}

\subsubsection{Espectrofotometria UV-visível por Leucocristal de Violeta (LCV)}

A determinação de antimônio foi realizada como descrito por Tiwari et al., 2006. Alíquotas das amostras de antimônio receberam uma solução de iodato de potássio 1 $\%(\mathrm{~m} / \mathrm{v})$, seguido por adição de solução de ácido clorídrico $0,5 \mathrm{~mol} \mathrm{~L}^{-1}$. Após agitação, foi adicionada a solução de leucocristal de violeta (LCV) e solução de hidróxido de sódio 2,0 mol $\mathrm{L}^{-1}$. A mistura foi mantida a $45{ }^{\circ} \mathrm{C}$ por alguns minutos. Em seguida, foi diluída com água e mantida por 20 minutos à temperatura ambiente para desenvolvimento completo da reação. $\mathrm{O}$ pH foi medido e $200 \mu \mathrm{L}$ da mistura foram adicionados a uma microplaca de 96 poços. A absorção foi medida em espectrofotômetro UV-visível num comprimento de onda de $590 \mathrm{~nm}$. Foi feita uma curva padrão usando uma solução de $\mathrm{Sb}(\mathrm{III})$. Para a redução de $\mathrm{Sb}(\mathrm{V})$ a $\mathrm{Sb}(\mathrm{III})$, foi adicionado iodeto de potássio $30 \%$ (3) (FIG. 12). A presença de excesso de iodo, indicado pela cor marrom clara foi destruída, adicionando algumas gotas de ácido ascórbico $5 \%$. Em seguida, alíquotas desta solução foram analisadas pelo procedimento geral de determinação de antimônio. Todas as medidas foram realizadas em temperatura ambiente e efetuadas em triplicata. Análise de regressão linear da curva de calibração foi feita usando o software de estatística Graph Pad Prism 5.02.

$$
\begin{gathered}
\text { Reação de Redução } \mathrm{Sb}(\mathrm{V}) \rightarrow \mathrm{Sb}(\mathrm{III}): \\
\text { 1. } \mathrm{Sb}(\mathrm{V})+2 \mathrm{e}^{-} \rightarrow \mathrm{Sb}(\mathrm{III}) \\
\text { 2. } 2 \mathrm{I}^{-} \rightarrow \mathrm{I}_{2}+2 \mathrm{e}^{-} \\
\mathbf{1 + 2}=\mathrm{Sb}(\mathrm{V})+2 \mathrm{I}^{-} \leftrightarrow \mathrm{Sb}(\mathrm{III})+\mathrm{I}_{2}
\end{gathered}
$$




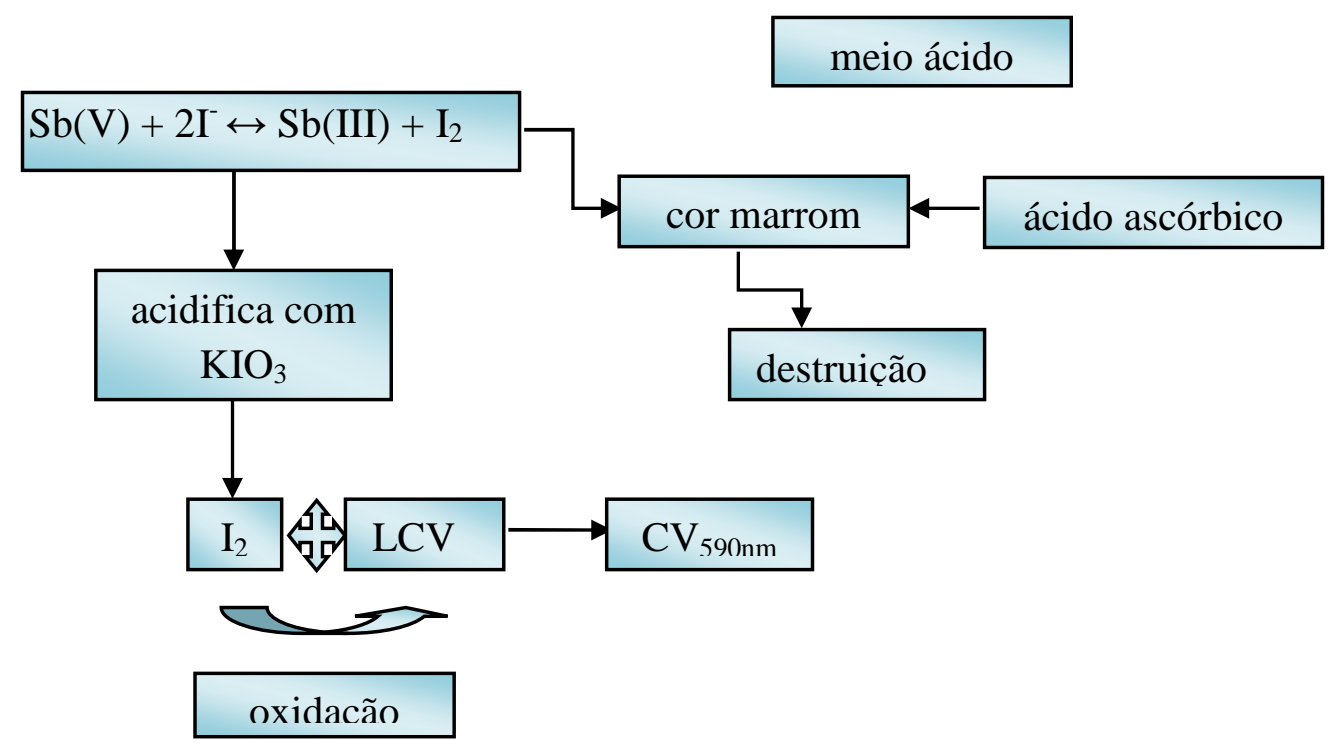

FIGURA 12 - Esquema do processo de redução e determinação do $\mathrm{Sb}(\mathrm{V})$.

\subsubsection{Voltametria de Pulso Diferencial (VPD)}

Antimônio foi determinado especificamente por Voltametria de Pulso Diferencial (VPD) em colaboração com o Instituto de Ecologia Terrestre - Proteção do Solo (ETH - Zurique - Suíça). As medidas foram feitas em um sistema de três eletrodos composto por: eletrodo de gota pendente de mercúrio (HMDE), eletrodo de referência de $\mathrm{Ag} / \mathrm{AgCl} / \mathrm{KCl}\left(3 \mathrm{~mol} \mathrm{~L}^{-1}\right)$ e um eletrodo auxiliar de Pt. A calibração foi feita com soluções padrões de $\mathrm{Sb}(\mathrm{V})$. As condições estabelecidas para o método foram: pulso de amplitude de $0,01 \mathrm{~V}$, velocidade de varredura de $0,0397 \mathrm{~V} / \mathrm{s}$, tempo de deposição de 3 min e potencial de deposição de -0,4 V. A quantificação foi realizada pelo método da adição de padrão. Foi adicionado $9,8 \mathrm{~mL}$ da amostra e $5 \mathrm{~mL}$ de $\mathrm{HCl} 30 \% \mathrm{v} / \mathrm{v}$. Inicialmente, alíquotas das amostras de lipossoma foram diluídas em $\mathrm{HCl} 32 \%$ e subsequentemente, diluídas em água bidestilada, $1 \times 10^{4}$ a $1 \times 10^{6}$ vezes até atingir níveis de concentração da ordem de $\mu \mathrm{g} / \mathrm{L}$. Foi usado para o cálculo o software 797 VA Computrace 1.3.

\subsubsection{Espectrometria de Emissão Ótica com Plasma Acoplado Indutivamente (ICP- OES)}

A técnica ICP-OES é baseada na medida de emissão de luz dos íons e átomos excitados. A excitação ocorre no plasma de argônio em temperatura acima de 10000 K. A 
intensidade de radiação luminosa no comprimento de onda de $206,83 \mathrm{~nm}$ permitiu a quantificação de antimônio.

Inicialmente, para a determinação de antimônio total foi elaborado uma curva analítica empregando uma solução padrão de referência certificada de antimônio $\left(\mathrm{Sb}_{2} \mathrm{O}_{3}\right)$ entre 0,1 a $10 \mathrm{mg} / \mathrm{L}$. As amostras foram diluídas em uma solução ácida contendo $1 \%$ $\mathrm{HNO}_{3}$ e $5 \% \mathrm{HCl}$ de forma que a quantidade de antimônio se situasse aproximadamente no meio da curva analítica. Para a construção da curva analítica foi empregada a linha de 206,834 nm. As amostras foram analisadas no ICP-OES com detecção simultânea e configuração axial (Vista - MPX, Varian). O gás para a formação do plasma foi o xenônio e os parâmetros instrumentais e analíticos aplicados estão apresentados na TAB. 09. Para o cálculo foi utilizado o programa Microsoft Office Excel 2007.

TABELA 09 - Parâmetros utilizados para determinação de antimônio por ICP-OES.

\begin{tabular}{cc}
\hline & Condições Gerais \\
\hline Potência (kW) & 1,2 \\
Vazão/Plasma (L/min) & 15,0 \\
Vazão/Auxiliar (L/min) & 1,50 \\
Vazão/Nebulizador (L/min) & 0,75 \\
Tempo de leitura das replicatas (s) & 5 \\
Tempo estabilização (s) & 10 \\
\hline \multicolumn{1}{c}{ Introdução da amostra } \\
\hline Captação da amostra (s) & 10 \\
Tempo de lavagem (s) & 10 \\
Vazão da bomba (rpm) & 10 \\
Replicatas (n) & 3 \\
\hline & Calibração \\
\hline Modo de calibração & quantitativo \\
Padrões (n) & 6 \\
Coeficiente de calibração & 0,990 \\
\hline
\end{tabular}

\subsubsection{Análise por Ativação Neutrônica Instrumental (AAN)}

A determinação de antimônio foi realizada pelo método comparativo de análise por ativação com nêutrons, no qual a amostra e um padrão do elemento a ser determinado são irradiados simultaneamente, sob as mesmas condições e, ambos medidos com o mesmo detector. Desta forma, o fluxo de nêutrons térmicos incidentes no elemento, a seção de choque de captura de nêutrons térmicos, o tempo de irradiação, a eficiência do sistema de detecção e todas as outras variáveis associadas às contagens são constantes tanto para a 
amostra como para o padrão, tornando possível a determinação da concentração do elemento na amostra através de uma comparação entre as atividades induzidas na amostra e no padrão, uma vez que a taxa de emissão de radiação por um material é proporcional ao seu número de átomos.

O antimônio foi determinado por Análise por Ativação Neutrônica Instrumental (AAN) como descrito por Osso et al., 2009. Alíquotas das soluções de antimônio livre e lipossomal foram colocadas em tubos de polipropileno e acondicionadas dentro de um recipiente de alumínio, juntamente com um padrão de referência certificado de antimônio. A irradiação ocorreu no Reator Nuclear IEA-R1m (IPEN/CNEN-SP), com fluxo de nêutrons térmicos de $0,8-1,0 \times 10^{12} \mathrm{n} / \mathrm{cm}^{2} \mathrm{~s}$ durante 15 minutos. As amostras irradiadas foram medidas após 2 dias do decaimento radioativo para o raio gama de 564 $\mathrm{keV}$ do ${ }^{122} \mathrm{Sb}$. As amostras foram contadas por 300 - 1800 segundos utilizando um detector de Germânio (Ge) hiper puro (Canberra Company), gerenciado pelo programa Genie-PC. A concentração de antimônio na amostra foi determinada por comparação com a concentração de antimônio no padrão que continha quantidades semelhantes de elemento como as amostras irradiadas (4). A precisão das medições foi calculada como o erro estatístico de contagem da área do pico. Durante a medição dos raios gama o tempo morto foi mantido abaixo dos $10 \%$.

$$
\frac{C_{p}}{C_{a}}=\frac{A_{p}}{A_{a}}
$$

Onde:

$\mathrm{C}_{\mathrm{a}}=$ concentração de antimônio na amostra

$\mathrm{C}_{\mathrm{p}}=$ concentração de antimônio no padrão

$\mathrm{A}_{\mathrm{a}}=$ atividade de antimônio na amostra

$\mathrm{A}_{\mathrm{p}}=$ atividade de antimônio no padrão

\subsubsection{Produção e Análise do Antimoniato de Meglumina Irradiado com Nêutrons} (AMI)

A fim de se produzir um radiotraçador de antimônio foram irradiadas amostras de antimoniato de meglumina para posterior avaliação de sua biodistribuição em um 
sistema in vivo. Para a produção de ${ }^{122} \mathrm{Sb}$ e ${ }^{124} \mathrm{Sb}$ (Borborema et al., 2005 a), amostras de 0,5-0,8 mL do antimoniato de meglumina (Glucantime®; Aventis, SP, Brasil) foram colocadas em um tubo de polipropileno e acondicionado dentro de um recipiente de alumínio. A irradiação ocorreu no Reator Nuclear IEA-R1m (IPEN/CNEN-SP), com fluxo de nêutrons térmicos de $1,0-11 \times 10^{12} \mathrm{n} / \mathrm{cm}^{2} \mathrm{~s}$ durante $5,15,20$ e 30 minutos. Os radioisótopos foram produzidos através das reações nucleares: ${ }^{121} \mathrm{Sb}(\mathrm{n}, \gamma){ }^{122} \mathrm{Sb}$ e ${ }^{123} \mathrm{Sb}(\mathrm{n}, \gamma){ }^{124} \mathrm{Sb}$.

Para as análises quantitativas e qualitativas dos radionuclídeos que emitem raios gama foi usado o espectrômetro de radiação gama constituído de um detector coaxial de germânio hiperpuro (HPGe), acoplado a um sistema de aquisição multicanal (Canberra Inc.). A calibração em energia gama foi realizada utilizando fontes calibradas de ${ }^{60} \mathrm{Co} e$ ${ }^{137}$ Cs. A atividade das amostras foi medida pelo mesmo sistema após a calibração da eficiência com fontes padrões de ${ }^{60} \mathrm{Co},{ }^{137} \mathrm{Cs}$ e ${ }^{152} \mathrm{Eu}$.

Para as análises quantitativas, a atividade foi calculada pela expressão (5):

$$
d p s=\frac{c p s}{a_{y} \cdot \varepsilon_{y}}
$$

Onde:

$\mathrm{dps}=$ atividade em desintegrações por segundo $(\mathrm{Bq})$;

cps = área do pico de interesse dividida pela contagens, em segundos;

$a_{\gamma}=$ abundância gama do pico de energia de interesse;

$\varepsilon_{\gamma}=$ eficiência do detector para a energia gama de interesse.

Sendo que: $1 \mathrm{dps}=1 \mathrm{~Bq}$ e $1 \mathrm{Ci}=3,7 \times 10^{10} \mathrm{~Bq}$.

A eficiência do detector em função das energias gamas foi determinada fazendo as contagens de fontes calibradas, ${ }^{60} \mathrm{Co},{ }^{137} \mathrm{Cs}$ e ${ }^{152} \mathrm{Eu}$ em seis posições em relação ao detector.

O cálculo da $\varepsilon$ é dado pela equação (6):

$$
\ln \varepsilon=a \cdot \ln E \gamma+b
$$


Onde:

$\varepsilon=$ eficiência do detector para a energia gama na posição em que foi contada a amostra no detector de germânio.

Para cada uma das seis posições existe uma equação que relaciona a E $\gamma$ com a eficiência.

\subsubsection{Estudos Biológicos}

\subsubsection{Animais de laboratório}

Os estudos foram realizados em hamster sírio dourado (Mesocricetus auratus), macho recém-desmamado e camundongo BALB/c fêmea pesando entre 20 e $25 \mathrm{~g}$, fornecidos pelo Biotério Central da Faculdade de Medicina - USP. Os camundongos C57B1/6 e MacGreen foram fornecidos e mantidos pelo Biotério da Universidade de Zurique. Todos os animais foram mantidos em ambiente controlado dentro de caixas esterilizadas com material absorvente, alimentados com ração comercial e água à vontade. Todos os procedimentos foram realizados sob aprovação da Comissão de Ética em Pesquisa IMTSP-USP-SP/Brasil (CEP-IMTSP/012/29042008) (Anexo 1) e Departamento de Medicina Veterinária do Cantão de Zurique (Suíça).

\subsubsection{Células}

Amastigotas de Leishmania (L.) chagasi (MHOM/BR/1972/LD) de baço de hamster dourado infectado foram purificadas através de centrifugação diferencial e a infecção avaliada pelo método de Stauber e colaboradores (1958) após 60-70 dias do inóculo. $\mathrm{O}$ inóculo foi realizado com solução salina na concentração de $5-7 \times 10^{7}$ parasitos/hamster, via intraperitoneal, para a manutenção da cepa.

Promastigotas de Leishmania (L.) chagasi (MHOM/BR/1972/LD) foram mantidas em meio M199 suplementado com $10 \%$ de soro fetal bovino (SFB), 0,25\% de hemina, antibióticos e $2 \%$ de urina humana, incubadas em estufa tipo B.O.D. a $24{ }^{\circ} \mathrm{C}$.

Amastigotas de Leishmania (L.) major (MHOM/IL/81/FEBNI) foram gentilmente cedidas pelo Prof ${ }^{\circ}$ Dr. Manfred Kopf (Instituto Federal Suíço de Tecnologia ETH - Zurique - Suíça). Os parasitos foram cultivados em meio de Drosophila de Schneider suplementado com L-glutamina, antibióticos e $20 \%$ SFB, incubadas em estufa 
tipo B.O.D. a $27{ }^{\circ} \mathrm{C}$. Todos os estudos conduzidos com esta espécie foram realizados na Universidade de Zurique (Suíça) sob a supervisão do Dr. Reto A. Schwendener.

Células macrofágica RAW 264.7 (ATCC TIB-71) foram cultivadas em meio de cultura RPMI-PR ${ }^{-}$1640, suplementado com $10 \%$ de SFB e antibióticos, incubadas em estufa com $5 \% \mathrm{CO}_{2}$ a $37{ }^{\circ} \mathrm{C}$.

Macrófagos peritoneais foram coletados da cavidade peritoneal de camundongos BALB/c, C57Bl/6 e MacGreen através da lavagem com meio RPMI-PR 1640, suplementado com $10 \%$ SFB e posteriormente aplicados em placas de cultura. As células foram incubadas por um período de $2 \mathrm{~h}$ a $37{ }^{\circ} \mathrm{C}$ em estufa com $5 \% \mathrm{CO}_{2}$ para adesão à placa. As células não aderentes foram removidas através de lavagem em meio de cultura a $25{ }^{\circ} \mathrm{C}$ e posteriormente incubadas nas mesmas condições por um período de 24 ou 48 horas até o momento do uso.

\subsubsection{Determinação da Concentração Efetiva $50 \%\left(\mathrm{CE}_{50}\right)$ em promastigotas de $L$. (L.) chagasi}

Com o objetivo de se verificar a efetividade das diferentes formulações foi realizada a determinação da Concentração Efetiva $50 \%\left(\mathrm{CE}_{50}\right)$ das formulações FDEL e FEL em promastigotas de L. (L.) chagasi (Tempone et al., 2005 a). Promastigotas foram contadas em hemocitômetro (câmara de Neubauer) e 1 x $10^{6}$ células/poço foram semeadas em microplaca de 96 poços. As formulações de antimônio lipossomal foram diluídas em meio de cultura apropriado e incubadas em diferentes concentrações com os parasitos, por $24 \mathrm{~h}$ a $24{ }^{\circ} \mathrm{C}$. Como controle foi utilizado o fármaco livre. A viabilidade dos parasitos foi verificada através do ensaio baseado no sal de tetrazólio - MTT (TADA et al., 1986). Resumidamente, a redução do MTT é um método colorimétrico rápido, usado para medir proliferação celular e viabilidade celular. O MTT é acumulado pelas células por endocitose e a redução do anel tetrazólico (de cor amarela) deste sal resulta na formação de cristais de formazan de cor azul que se acumulam em compartimentos endossomais e/ou lisossomais, sendo depois transportados para fora das células por exocitose, sendo a endocitose um mecanismo fundamental das células vivas. A quantidade de conversão do corante em solução pode ser medida espectrofotometricamente. Desta forma, foi adicionado solução tampão fosfato (PBS) contendo MTT $(20 \mu \mathrm{L}, 5 \mathrm{mg} / \mathrm{mL})$ em cada poço. Após $4 \mathrm{~h}$ de incubação a $25{ }^{\circ} \mathrm{C}$ foi adicionado $100 \mu \mathrm{L}$ /poço de SDS $10 \%$ :isopropanol (v/v, 1:1) por 15 min a $25^{\circ} \mathrm{C}$. A medida foi realizada em espectrofotômetro num comprimento de onda de 
$570 \mathrm{~nm}$ (Tada et al., 1986). A CE $\mathrm{C}_{50}$ foi analisada pelo software Graph Pad Prism 5.02, através de uma curva sigmóide dose-resposta, usando a média de três experimentos em duplicata.

\subsubsection{Determinação da Concentração Efetiva $50 \%\left(\mathrm{CE}_{50}\right)$ em promastigotas de $L$.} (L.) major

Com o objetivo de se verificar a efetividade das diferentes formulações foi realizada a determinação da Concentração Efetiva $50 \%\left(\mathrm{CE}_{50}\right)$ das formulações FTL em promastigotas de L. (L.) major. Promastigotas foram contadas em hemocitômetro (câmara de Neubauer) e $1 \times 10^{6}$ células/poço foram semeadas em microplaca de 96 poços. As formulações de antimônio lipossomal foram diluídas em meio de cultura apropriado e incubadas em diferentes concentrações com os parasitos, por $24 \mathrm{~h}$ a $24{ }^{\circ} \mathrm{C}$. Como controle foi utilizado o fármaco livre. A viabilidade dos parasitos foi verificada através do ensaio com Resazurina. Resumidamente, este método é desenvolvido para a determinação colorimétrica do número de células em função de sua atividade metabólica. O componente chave é o corante resazurina, indicador de oxidoredução. A bioredução do corante por conversão metabólica na mitocôndria de células viáveis reduz a quantidade de sua forma oxidada (azul) e concomitantemente aumenta a quantidade de sua fluorescência intermediária (vermelha), indicando o nível de citotoxicidade do produto testado. A quantidade de conversão do corante em solução pode ser medida espectrofluorimetricamente ou espectrofotometricamente. Desta forma, foi adicionado meio de cultura contendo resazurina $(100 \mu \mathrm{L}, 20: 1$, v/v) em cada poço. Após $3 \mathrm{~h}$ de incubação a $27{ }^{\circ} \mathrm{C}$ o produto fluorescente pode ser determinado usando um espectrofluorímetro com medidas de fluorescência num comprimento de onda de emissão de $590 \mathrm{~nm}$ e excitação em $560 \mathrm{~nm}$. A $\mathrm{CE}_{50}$ foi analisada pelo software Graph Pad Prism 5.02, através de uma curva sigmóide dose-resposta, usando a média de três experimentos em duplicata. A viabilidade celular $(100 \%)$ foi expressa com base na unidade de fluorescência do controle positivo (células incubadas sem fármaco), após normalização. 


\subsubsection{Determinação da Concentração Efetiva $50 \%\left(\mathbf{C E}_{50}\right)$ em macrófago peritoneal infectado com Leishmania}

Macrófagos peritoneais foram semeados com 4 x $10^{5}$ células/poço em microplaca de 24 poços, contendo lamínulas de vidro (13 $\mathrm{mm}$ de diâmetro). As células foram incubadas por $24 \mathrm{~h}$ a $37{ }^{\circ} \mathrm{C}$ em estufa com $5 \% \mathrm{CO}_{2}$ para adesão à placa. Promastigotas de L. (L.) major ou amastigotas de L. (L.) chagasi foram adicionadas aos macrófagos na proporção de 1:10 (macrófagos/amastigotas) e incubadas nas mesmas condições por $24 \mathrm{~h}$. Os parasitos não internalizados foram removidos por lavagem. As formulações de antimônio lipossomal foram diluídas e incubadas com os macrófagos infectados, por um período de $120 \mathrm{~h}$ nas mesmas condições. Ao final, as lamínulas foram fixadas com metanol, coradas com Giemsa e observadas em microscópio óptico comum. A determinação da $\mathrm{CE}_{50}$ foi realizada através da contagem de 400 macrófagos/lamínula, usando como controle de $100 \%$ de infecção os macrófagos não tratados. Os dados foram avaliados pelo software Graph Pad Prism 5.02, através de uma curva sigmóide doseresposta, usando a média de três experimentos em duplicata (Tempone et al., 2005 b).

\subsubsection{Determinação da citotoxicidade}

Com o objetivo de se verificar a citotoxicidade das diferentes formulações de lipossomas foi realizada a determinação da Concentração Efetiva $50 \%\left(\mathrm{CE}_{50}\right)$ em células de mamíferos. Células RAW 264.7 ou macrófagos peritoneais foram semeados com 1 - 4 x

$10^{4}$ células/poço em microplaca de 96 poços. Após 24 h, o meio de crescimento foi trocado por soluções de antimônio lipossomal diluídas em meio de cultura e incubadas em diferentes concentrações por 48 horas a $37{ }^{\circ} \mathrm{C}$ em estufa com $5 \% \mathrm{CO}_{2}$. A viabilidade celular foi verificada através do ensaio com MTT ou com Resazurina. Os dados foram avaliados pelo software Graph Pad Prism 5.02, através de uma curva sigmóide doseresposta, usando a média de três experimentos em duplicata.

A determinação do Índice de Seletividade (IS) foi avaliada através da seguinte fórmula (7):

$$
\mathbf{I S}=\frac{\text { Citotoxicidade }\left(\mathrm{CE}_{50} \text { em células de mamífero }\right)}{\mathrm{CE}_{50} \text { em amastigota de Leishmania }}
$$




\subsubsection{Estudos de Interação Célula-Lipossoma}

\subsection{Captação e internalização de lipossoma marcado com corante fluorescente por macrófago RAW 264.7 não infectado e infectado com $L$. $(L$.$) major$}

Com o objetivo de investigar a captação e internalização de lipossomas por macrófagos foram preparados lipossomas marcados com corante fluorescente como descrito anteriormente. Células RAW 264.7 foram semeadas com 4 x $10^{4}$ células/poço em microplaca de 24 poços, contendo lamínulas de vidro (13 $\mathrm{mm}$ de diâmetro). As células foram incubadas por $24 \mathrm{~h}$ a $37{ }^{\circ} \mathrm{C}$ em estufa com $5 \% \mathrm{CO}_{2}$. Para a infecção das células, promastigotas de L. (L.) major foram adicionadas aos macrófagos na proporção de 1:10 (macrófagos/promastigotas) e incubadas nas mesmas condições por $24 \mathrm{~h}$. Os parasitos não internalizados foram removidos por lavagem. Foi adicionado meio de cultura OptiMEM-1, com concentração reduzida de soro, no qual os lipossomas Dil-FTL foram diluídos $(10 \mu \mathrm{L}$ ou $25 \mu \mathrm{L}$ lipossoma em $500 \mu \mathrm{L}$ meio) e incubados por diferentes períodos de tempo. Posteriormente, as células foram lavadas com solução tampão fosfato (PBS), fixadas com formaldeído (3\% em PBS) e incubadas com DAPI ( $1 \mu \mathrm{g} / \mathrm{mL}$ em PBS) por $10 \mathrm{~min}$ para a coloração do núcleo. Finalmente, as células foram lavadas com PBS e analisadas em um microscópio de fluorescência. Para a quantificação da captação de lipossomas fluorescentes por macrófagos, o número de células contendo fluorescência foi determinado contando 200 células/lamínula. A porcentagem de captação foi calculada considerando o número de células sem fluorescência como $100 \%$. As figuras foram preparadas usando o programa Adobe Photoshop. Os dados foram avaliados pelo software Graph Pad Prism 5.02, através de uma curva sigmóide dose-resposta, usando a média de dois experimentos em duplicata.

\subsection{Associação e captação de lipossoma marcado com corante fluorescente por macrófago RAW 264.7 não infectado e infectado com $L$. (L.) major usando citometria de fluxo (FACS)}

A citometria de fluxo, também denominada como Separador de Célula Ativada por Fluorescência (Fluorescence Activated Cell Sorting - FACS) é uma técnica que permite a contagem de células e a separação de subpopulações celulares, é uma análise 
multiparamétrica simultânea das características físicas e químicas de uma única célula em suspensão baseada no espalhamento de luz e fluorescência de cada célula.

Com o objetivo de investigar a associação e a captação de lipossomas por macrófagos foram preparados lipossomas marcados com corante fluorescente como descrito anteriormente. Células RAW 264.7 foram semeadas com 2 × $10^{5}$ células/poço em placa de 6 poços e incubadas por $24 \mathrm{~h}$ a $37{ }^{\circ} \mathrm{C}$ em estufa com $5 \% \mathrm{CO}_{2}$. Para a infecção das células, promastigotas de $L$. (L.) major foram adicionadas aos macrófagos na proporção de 1:10 (macrófagos/promastigotas) e incubadas nas mesmas condições por $24 \mathrm{~h}$. Os parasitos não internalizados foram removidos por lavagem. Foi adicionado meio de cultura OptiMEM-1 no qual os lipossomas Dil-FTL foram diluídos $(10 \mu \mathrm{L}$ ou $25 \mu \mathrm{L}$ lipossoma em $500 \mu \mathrm{L}$ meio) e incubados por diferentes períodos de tempo. Posteriormente, as células foram lavadas, raspadas gentilmente da placa e fixadas com formaldeído (10\% em PBS). Finalmente, as células foram lavadas PBS $(1 \mathrm{x})$ e analisadas por citometria de fluxo $\left(\mathrm{CyAn}{ }^{\mathrm{TM}}\right)$ para distinguir as duas populações celulares de acordo com os tempos estudados.

\subsubsection{Estudos de biodistribuição do antimônio lipossomal (FDEL-AMI)}

Os estudos de biodistribuição do FDEL-AMI foram realizados em camundongos BALB/c fêmeas sadias (20-24 g) $(\mathrm{n}=5)$ (Borborema, 2005). Foi administrado dose traço do fármaco encapsulado, contendo atividade adequada para determinação da radioatividade por meio de contador gama. Nos animais foram injetados, por via intraperitoneal, $100 \mu \mathrm{L}$ de FDEL-AMI, contendo 1,0 mg Sb e a atividade de aproximadamente $1 \times 10^{3} \mathrm{~Bq}(0,03 \mu \mathrm{Ci}) \mathrm{de}^{122} \mathrm{Sb}$ e $2,5 \times 10^{2} \mathrm{~Bq}(0,007 \mu \mathrm{Ci}) \mathrm{de}^{124} \mathrm{Sb}$. Após $5,15,30,60,120,300,1080,1440$ e 2880 minutos, amostras de sangue foram colhidas e os animais foram sacrificados por deslocamento cervical. Os órgãos foram retirados, lavados e pesados. A atividade foi medida em um contador de cintilação de $\mathrm{NaI}(\mathrm{Tl})$ automático (Cobra Auto-Gamma - Canberra Company). Para os estudos de musculatura esquelética, adotou-se como massa $40 \%$ do peso corpóreo e para a análise do sangue, adotou-se a volemia equivalente a $7 \%$ do peso corpóreo. A análise de dados foi realizada com o software Graph Pad Prism 5.02. A porcentagem de atividade de cada órgão foi calculada a partir da contagem do padrão equivalente a $100 \%$ da atividade injetada, com a seguinte fórmula (8): 


$$
\% \text { dose / órgão }=\frac{c p m / \text { órgão }}{\text { dose ad } \min \text { istrada }(\mathrm{cpm})} \times 100
$$

Onde:

$\mathrm{cpm}=$ contagem por minuto

A fim de se comparar à afinidade relativa da formulação lipossomal por diferentes órgãos foram analisados os dados de biodistribuição através de cálculo da porcentagem da atividade administrada por grama de tecido analisado, para se compensar a aparente captação que ocorreu em órgãos que possuem maior massa, com a seguinte fórmula (9):

$$
\% \text { dose / grama }=\frac{c p m / \text { grama de órgão }}{\text { dose ad } \min \text { istrada }(\mathrm{cpm})} \times 100
$$

\subsubsection{Análise Estatística}

Os resultados e os parâmetros estimados foram descritos com a média e o desvio padrão. O teste t de Student foi aplicado para a análise estatística dos dados de biodistribuição. $\mathrm{O}$ nível de significância $\mathrm{P}<0,05$ foi considerado estatisticamente significante. 


\section{RESULTADOS COMENTADOS}

\subsection{Determinação de Antimônio Total}

Foram analisadas amostras de soluções de $\mathrm{Sb}(\mathrm{III})$ e $\mathrm{Sb}(\mathrm{V})$, antimoniato de meglumina e antimoniato de meglumina encapsulado em lipossomas. O antimoniato de meglumina (Glucantime $\left.{ }^{\circledR}\right)$ é utilizado no Brasil para o tratamento das Leishmanioses e comercializado em ampolas de $5 \mathrm{~mL}$. De acordo com o fabricante, cada ampola contém 1,5 g de antimoniato de meglumina (equivalente a $405 \mathrm{mg}$ de antimônio pentavalente) o qual corresponde a $81 \mathrm{mg} / \mathrm{mL}$ de $\mathrm{Sb}(\mathrm{V})$. O conteúdo total de antimônio nas diferentes amostras foi determinado por diversos métodos tais como: LCV, VPD, ICP-OES e AAN e comparados entre si.

\subsubsection{Espectrofotometria UV-visível por Leucocristal de Violeta (LCV)}

Para determinar a concentração de antimônio em diferentes amostras, tais como, solução inorgânica de antimônio, fármaco e lipossomas, foi empregado um método analítico de baixo custo e simples. Como o $\mathrm{Sb}(\mathrm{III})$ promove a liberação do iodo do iodato de potássio acidificado e, em seguida, o iodo liberado seletivamente oxida o leucocristal de violeta em cristal de violeta apresentando absorbância máxima em $590 \mathrm{~nm}$, foi possível a determinação espectrofotométrica de antimônio total.

Quando concentrações de $0,05-1 \mathrm{mg} / \mathrm{mL}$ de antimônio foram utilizadas as soluções padrão revelaram cor marrom clara, provavelmente causado por excesso de iodo. Concentrações mais elevadas de antimônio $(1,4-2,0 \mathrm{mg} / \mathrm{mL})$ podem evitar a oxidação do LCV e resultaram em uma solução incolor. Utilizando concentrações menores, entre 0,1 $10 \mu \mathrm{g} / \mathrm{mL}$ de antimônio, foi possível estabelecer uma curva de calibração linear satisfatória. Todas as soluções padrão apresentaram coloração azul arroxeado claro. $\mathrm{O}$ pH variou entre 3 - 4. Como mostrado na FIG. 13 foi obtida uma curva de calibração com regressão linear $\mathrm{y}=0,0773 \mathrm{x}+0,02499, \mathrm{r}^{2}=0,9927$. 


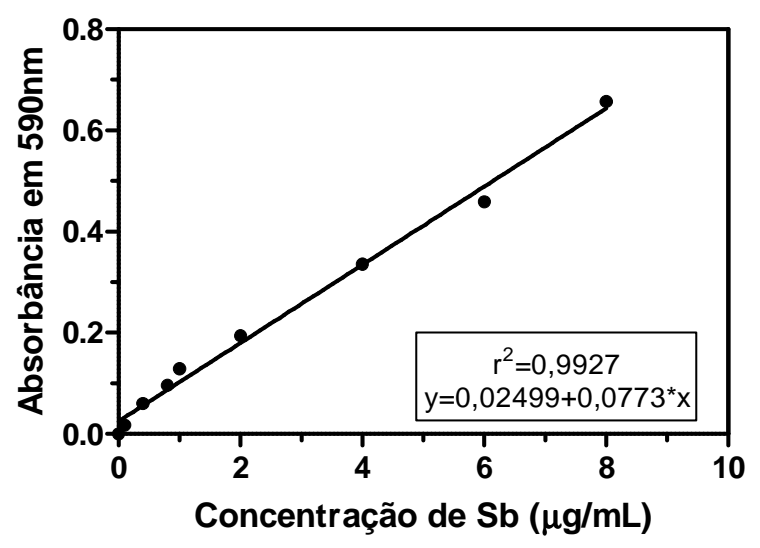

FIGURA 13 - Curva de calibração do antimônio por determinação espectrofotométrica usando leucocristal de violeta num comprimento de onda de $590 \mathrm{~nm}$.

Foi obtida uma adequada curva de calibração da solução de $\mathrm{Sb}(\mathrm{III})$, mostrando alta repetibilidade e um elevado coeficiente de correlação. Assim, a determinação do antimônio em diferentes amostras, tais como antimoniato de meglumina, soluções padrão de $\mathrm{Sb}(\mathrm{V})$ e $\mathrm{Sb}(\mathrm{III})$ foi executada. Anteriormente, alíquotas contendo $\mathrm{Sb}(\mathrm{V})$ foram reduzidas para $\mathrm{Sb}(\mathrm{III})$ com uma solução contendo iodeto de potássio $30 \%$ e ácido ascórbico $5 \%$. Esta análise revelou mais de $100 \%$ de recuperação de antimônio apenas em soluções de $\mathrm{Sb}(\mathrm{III})$, porém quando soluções contendo $\mathrm{Sb}(\mathrm{V})$ foram usadas não foi observado recuperação de antimônio (TAB. 10).

TABELA 10 - Determinação espectrofotométrica de antimônio usando leucocristal de violeta (LCV) média \pm desvio-padrão $(n=3)$.

\begin{tabular}{cccc}
\hline Amostras & $\begin{array}{c}\text { Sb Adicionado } \\
(\mathbf{m g} / \mathbf{m L})\end{array}$ & $\begin{array}{c}\text { Sb Encontrado } \\
(\mathbf{m g} / \mathbf{m L})\end{array}$ & $\begin{array}{c}\text { Recuperação } \\
(\boldsymbol{\%})\end{array}$ \\
\hline $\mathrm{Sb}(\mathrm{III})$ & 1 & $1,08 \pm 0,03$ & 106 \\
$\mathrm{Sb}(\mathrm{V})$ & 1 & - & - \\
$\mathrm{AM}$ & 81 & $6,8 \pm 0,2$ & 8 \\
\hline
\end{tabular}

Nas amostras de antimoniato de meglumina foi observada uma concentração de $6,8 \mathrm{mg} \mathrm{Sb} / \mathrm{mL}$, considerando que não foi possível a determinação de $\mathrm{Sb}(\mathrm{V})$, sugere-se que esta concentração seja referente ao $\mathrm{Sb}(\mathrm{III})$ presente na amostra, correspondendo a $8 \%$ do antimônio total especificado pelo fabricante.

Tiwari e colaboradores (2006) determinaram antimônio em amostras biológicas e ambientais utilizando LCV e, relataram a necessidade da redução do $\mathrm{Sb}(\mathrm{V})$ para $\mathrm{Sb}$ (III) para posterior quantificação espectrofotométrica. O mesmo procedimento foi conduzido 
neste trabalho, todavia não foi reprodutível, uma vez que não foi possível a quantificação em amostras contendo $\mathrm{Sb}(\mathrm{V})$.

Krachler e colaboradores (1999 a, b) relataram potenciais problemas com o processo de redução do antimônio com iodeto de potássio e ácido ascórbico: definição da quantidade exata dos reagentes de redução, concentrações precisas, tempo de reação, temperatura e pH. Além disso, a taxa de reconversão de $\mathrm{Sb}(\mathrm{III})$ em $\mathrm{Sb}(\mathrm{V})$ diminui com o aumento da acidez das soluções. Como verificado por Cohn e colaboradores (2005) o método LCV é fortemente afetado pelo $\mathrm{pH}$.

Rath e colaboradores (1997) descreveram um procedimento espectrofotométrico para determinação de antimônio em amostras de antimoniato de meglumina e como cromógeno foi escolhido o vermelho de bromopirogalol (BPR). A quantificação de $\mathrm{Sb}(\mathrm{V})$ foi realizada após sua redução para $\mathrm{Sb}(\mathrm{III})$ usando iodeto em meio fortemente ácido, porém a eficiência de redução foi de 72,2 $\pm 2,71 \%$ e, para o cálculo final os valores foram corrigidos com os dados da eficiência.

É importante salientar que foram observados níveis significativos de $\mathrm{Sb}$ (III) nas amostras de antimoniato de meglumina. Considerando que o fármaco tem uma concentração de antimônio pentavalente nominal de $81,0 \mathrm{mg} / \mathrm{mL}$, o teor de $\mathrm{Sb}$ (III) determinado neste estudo correspondeu a aproximadamente $8 \%$ do teor de $\mathrm{Sb}(\mathrm{V})$. Estes dados corroboram com os resultados reportados anteriormente usando polarografia, onde verificaram níveis de 10,06 a 18,96 mg Sb(III)/mL (10,5 a 15,8 \%) (Franco et al., 1995), método espectrofotométrico com BPR, onde constataram níveis de 5,19 a 10,52 mg $\mathrm{Sb}(\mathrm{III}) / \mathrm{mL}$ (Rath et al., 1997) e por voltametria de onda quadrada observaram níveis de 6,3 a 7,1 mg Sb(III)/mL (8 \%) (Doretto, 2008). Isto poderia explicar a variação na eficácia e nos efeitos colaterais verificados em indivíduos tratados com este medicamento.

O método espectrofotométrico empregando leucocristal de violeta como cromógeno demonstrou ser simples, rápido e reprodutível para determinação de $\mathrm{Sb}$ (III) em antimoniato de meglumina, assim poderia ser utilizado no controle de qualidade das formulações farmacêuticas.

\subsubsection{Voltametria de Pulso Diferencial (VPD)}

O antimônio trivalente é eletroativo no eletrodo de mercúrio e diversos métodos têm sido reportados ao longo dos anos para a determinação deste elemento por voltametria (Franco et al., 1995, Wagner et al., 1996). O antimônio pentavalente não é 
eletroativo no domínio de eletroatividade do eletrodo de mercúrio e, portanto, não pode ser determinado diretamente. Uma das possibilidades de realizar a determinação de $\mathrm{Sb}(\mathrm{V})$ por voltametria é através da formação de complexos e usando a voltametria adsortiva ou promover sua redução no eletrodo de mercúrio com $\mathrm{HCl} 6 \mathrm{~mol} \mathrm{~L}^{-1}$ e usando a voltametria por pulso diferencial (Wagner et al., 1996).

Consequentemente, a determinação por voltametria do antimônio em diferentes amostras foi realizada através do método da adição de padrão. Uma curva potencial versus corrente elétrica característica da análise de antimônio é mostrada na FIG. 14. O antimônio apresentou em $\mathrm{HCl} 32 \%$ um potencial de pico em - 0,15 V. Foi verificado, a partir dos voltamogramas obtidos, um aumento proporcional no valor da intensidade da corrente de pico para o antimônio.

A

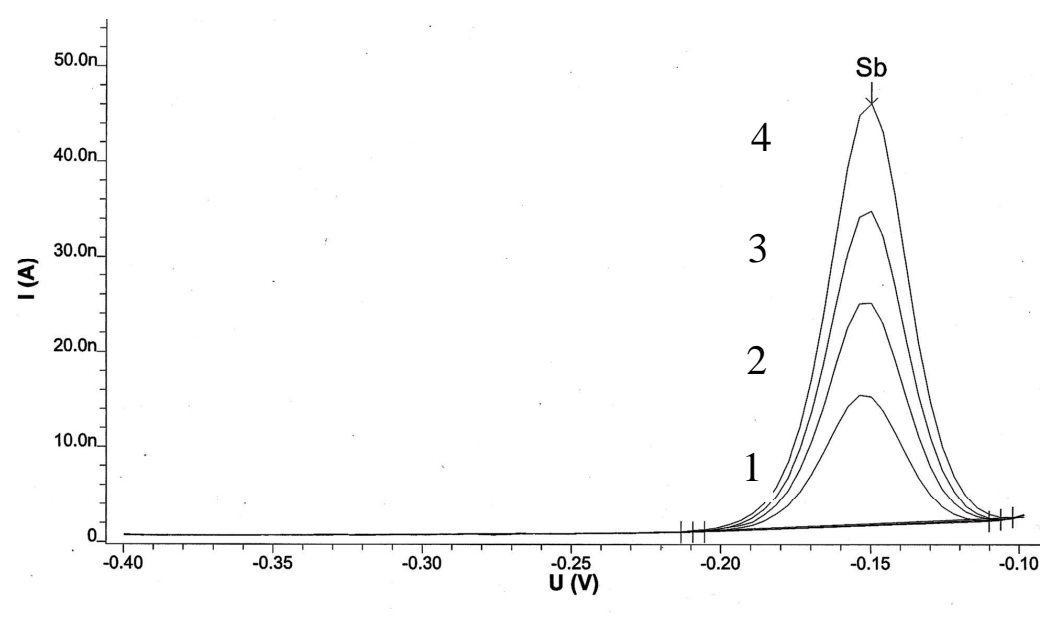

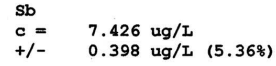

B $\quad \underline{\Xi}$

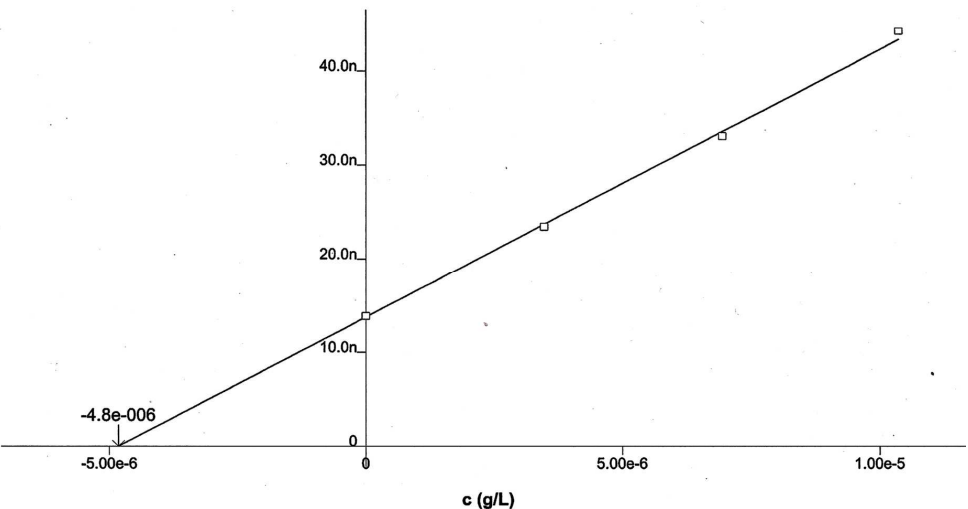

FIGURA 14 - Voltamograma característico do antimônio por Voltametria de Pulso Diferencial (A). Curvas: 1: Solução de $\mathrm{Sb}(\mathrm{V}) ; 2,3$ e 4: Adição de padrão; Método de adição de padrão (B). 
Os melhores resultados obtidos da quantificação do antimônio em diferentes soluções por VPD são descritos na TAB. 11. A recuperação mais elevada foi verificada na solução de $\mathrm{Sb}(\mathrm{III})$, com mais de $100 \%$. No entanto, nas outras amostras a recuperação não foi alta. As porcentagens obtidas de antimônio nas soluções de $\mathrm{Sb}(\mathrm{V})$ e antimoniato de meglumina foram $75 \%$ e $79 \%$, respectivamente. O antimônio encapsulado em lipossomas foi quantificado, porém os resultados não foram repetíveis.

TABELA 11 - Quantificação de antimônio em diferentes amostras por Voltametria de Pulso Diferencial (VPD).

\begin{tabular}{cccc}
\hline Amostras & $\begin{array}{c}\text { Sb Adicionado } \\
(\mathbf{m g} / \mathbf{m L})\end{array}$ & $\begin{array}{c}\text { Sb Encontrado } \\
(\mathbf{m g} / \mathbf{m L} \mathbf{L})\end{array}$ & $\begin{array}{c}\text { Recuperação } \\
(\mathbf{\%})\end{array}$ \\
\hline $\mathrm{Sb}(\mathrm{III})$ & 1 & 1,06 & 106 \\
$\mathrm{Sb}(\mathrm{V})$ & 1 & 0,75 & 75 \\
$\mathrm{AM}$ & 81 & 64,2 & 79 \\
\hline
\end{tabular}

A principal dificuldade encontrada no emprego dessa técnica foi à escolha adequada do processo de digestão e diluição das amostras, especialmente porque foram analisados três tipos diferentes de amostras, tais como soluções de sal de antimônio, fármaco comercial e antimônio encapsulado em lipossomas. Para verificar melhores procedimentos para diluir as amostras, diferentes soluções de ácido, como o ácido clorídrico e ácido sulfúrico, misturas de ácidos, mudança nas suas concentrações, variação do tempo de diluição e digestão em um forno de microondas foram aplicadas. Por último, os resultados mais repetíveis foram obtidos usando $\mathrm{HCl} 32 \%$ como agente de diluição.

Goodwin \& Page (1943) demonstraram o uso da voltametria como método de quantificação e especiação de antimônio em amostras biológicas (sangue e urina) provenientes de animais tratados com diferentes agentes antimoniais. $\mathrm{O} \mathrm{Sb}(\mathrm{V})$ foi determinado indiretamente após sua redução pela fervura com sulfeto de sódio.

O uso da voltametria de pulso diferencial foi demonstrado por Franco e colaboradores (1995) na quantificação de $\mathrm{Sb}(\mathrm{III})$ presentes nos medicamentos antileishmania, tais como antimoniato de meglumina (Glucantime) e estibogluconato de sódio (Pentostam), porém esta técnica não foi eficiente para a determinação de $\mathrm{Sb}(\mathrm{V})$ nas amostras, sendo empregado o método de titulação com iodo.

Wagner e colaboradores (1996) desenvolveram um método de especiação de antimônio em águas e ácido fosfórico utilizando voltametria adsortiva com redissolução usando como agente complexante o ácido cloranílico (AC). Neste estudo, os autores 
concluíram que o $\mathrm{Sb}(\mathrm{III})$ pode ser determinado em meio de $\mathrm{HCl}, \mathrm{pH}$ 3,0 usando um potencial de deposição $+0,1 \mathrm{~V}$, enquanto o $\mathrm{Sb}(\mathrm{V})$ pode ser determinado em meio $\mathrm{HCl}, \mathrm{pH}$ 1,0 usando um potencial de deposição de $-0,5$ V. No entanto, os autores não descreveram as reações e o processo eletroquímico envolvido, indicando que o método permite a especiação de antimônio pelo controle de $\mathrm{pH}$ do eletrólito suporte.

Doretto (2008) utilizou a voltametria adsortiva com redissolução catódica por onda quadrada como método de especiação de antimônio em antimoniato de meglumina sintetizado e em medicamento comercial. Considerando que o antimônio está complexado com a N-metilglucamina (NMG) e o Sb(III) está presente na amostra do fármaco, não foi viável aplicar o método voltamétrico para a quantificação de $\mathrm{Sb}(\mathrm{V})$ diretamente nas amostras. A quantificação somente poderia ser realizada após um tratamento prévio das amostras, no qual devem ser eliminados os interferentes. A maneira mais simples seria empregar uma digestão com ácido nítrico/ácido clorídrico, embora, nestas condições, ocorreria a destruição da matéria orgânica e da NMG, o $\mathrm{Sb}(\mathrm{III})$ seria oxidado para o $\mathrm{Sb}(\mathrm{V})$ e a quantificação seria com base no antimônio total presente nas amostras. Contudo, a concentração de $\mathrm{Sb}$ (III) poderia ser determinada diretamente por métodos voltamétricos já que este elemento é eletroativo no eletrodo de mercúrio e, a concentração de $\mathrm{Sb}(\mathrm{V})$ poderia ser determinada pela diferença.

\subsubsection{Espectrometria de Emissão Ótica com Plasma Acoplado Indutivamente (ICP- OES)}

Para a quantificação de antimônio por ICP-OES foi construída uma curva de calibração utilizando uma solução padrão certificada de antimônio. Após uma série de padronizações, a melhor curva analítica foi estabelecida pela diluição da solução padrão com água acidificada com $\mathrm{HNO}_{3} 1 \%$ v/v e $\mathrm{HCl} 5 \%$ v/v, na concentração de 1 a 10 mg/L. A curva analítica para o antimônio mostrou linearidade de 0,999 , com uma regressão linear $\mathrm{y}=579,27 \mathrm{x}+25,11($ FIG. 15$)$. 


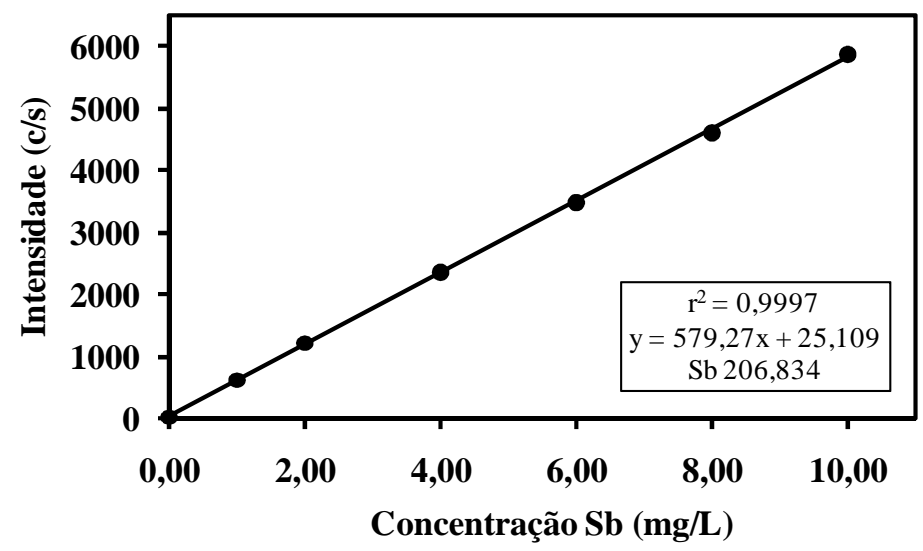

FIGURA 15 - Curva de calibração do antimônio por ICP-OES.

$\mathrm{Na}$ análise convencional por ICP-OES é necessário solubilizar as amostras. Para tanto, diferentes misturas de ácidos foram avaliadas, sistemas de digestão abertos e fechados, variações no tempo de aquecimento e regimes de temperatura foram abordados na otimização da metodologia. O melhor sinal foi obtido com as amostras diluídas com a mesma água acidificada utilizada na diluição dos padrões, porém esta abordagem não foi eficiente para todos os tipos de matrizes utilizadas e uma proporção substancial de material pode não ter sido completamente dissolvido, resultando em uma concentração subestimada ou superestimada. O sistema ICP-OES não apresentou adequada repetibilidade e recuperação de antimônio, mostrando instabilidade nas medidas. Os resultados das determinações são mostrados na TAB. 12.

TABELA 12 - Quantificação de antimônio em diferentes amostras por ICP-OES. Os dados são apresentados como a média \pm desvio padrão $(n=3)$.

\begin{tabular}{cccc}
\hline Amostras & $\begin{array}{c}\text { Sb Adicionado } \\
(\mathbf{m g} / \mathbf{m L})\end{array}$ & $\begin{array}{c}\text { Sb Encontrado } \\
(\mathbf{m g} / \mathbf{m L})\end{array}$ & $\begin{array}{c}\text { Recuperação } \\
(\mathbf{\%})\end{array}$ \\
\hline $\mathrm{Sb}(\mathrm{III})$ & 16 & $24 \pm 6$ & 148 \\
$\mathrm{Sb}(\mathrm{V})$ & 20 & $30 \pm 12$ & 148 \\
$\mathrm{AM}$ & 81 & $106 \pm 21$ & 131 \\
\hline
\end{tabular}

O conteúdo de antimônio no antimoniato de meglumina observado neste estudo corrobora com os resultados apresentados por Trivelin e colaboradores (2006). Os autores reportaram uma variação entre 89 a $110 \mathrm{mg} \mathrm{Sb}(\mathrm{V}) / \mathrm{mL}$ do fármaco analisado por ICP-OES e por extração líquido-líquido de análise em fluxo (LLE-FA). 
A determinação de antimônio nas formulações lipossomais apresentou resultados insatisfatórios, com baixa repetibilidade. Por causa da alta concentração de lipídios nas preparações dos lipossomas e da elevada temperatura de transição de fase dos fosfolipídios usados na composição é necessário submeter às amostras a um processo de digestão em ácido, sendo um procedimento muito dispendioso (Oliveira et al., 2006).

Além disso, interferências das soluções ácidas nas medidas por ICP-OES têm sido amplamente investigadas. Foi observado que os ácidos inorgânicos produzem uma redução da intensidade de emissões que pode ser atribuída aos fenômenos relacionados ao nebulizador, decorrentes de alterações nas propriedades físicas da solução ou aos efeitos relacionados com plasma. Efeitos combinados devido à mistura de ácidos inorgânicos também foram investigados, mostrando que interações significativas entre os ácidos afetam tanto os processos de introdução da amostra como as características térmicas do plasma (Grotti et al., 2003).

\subsubsection{Análise por Ativação Neutrônica Instrumental (AAN)}

Devido à dificuldade da determinação de antimônio com as metodologias descritas anteriormente, a análise por ativação neutrônica instrumental (AAN) também foi empregada neste trabalho. A fim de determinar a concentração de antimônio nas formulações de lipossomas e para caracterizar sua eficiência de encapsulação a AAN foi estabelecida. Os compostos usados contêm principalmente antimônio que representa uma vantagem após irradiação, evitando a atividade de fundo de outros elementos de matriz e a interferência na contagem direta da atividade de isótopos de baixa energia gama, já que foi usado o ${ }^{122} \mathrm{Sb}(563,9 \mathrm{keV})$ como traçador radioativo nas determinações. Na TAB. 13 são apresentados os resultados da análise em 3 diferentes amostras.

TABELA 13 - Quantificação de antimônio em diferentes amostras por Análise por Ativação Neutrônica Instrumental. Os dados são apresentados como a média \pm desvio padrão $(n=3)$.

\begin{tabular}{cccc}
\hline Amostras & $\begin{array}{c}\text { Sb Adicionado } \\
(\mathbf{m g} / \mathbf{m L})\end{array}$ & $\begin{array}{c}\text { Sb Encontrado } \\
(\mathbf{m g} / \mathbf{m L} \mathbf{)}\end{array}$ & $\begin{array}{c}\text { Recuperação } \\
(\mathbf{\%})\end{array}$ \\
\hline $\mathrm{Sb}(\mathrm{III})$ & 1 & $0,98 \pm 0,5$ & 98 \\
$\mathrm{Sb}(\mathrm{V})$ & 1 & $0,94 \pm 0,5$ & 95 \\
$\mathrm{AM}$ & 81 & $79,7 \pm 0,9$ & 98 \\
\hline
\end{tabular}


Foi verificada uma excelente resposta entre os resultados, em especial na amostra de antimoniato de meglumina, onde o conteúdo estimado obtido pelo método AAN foi muito próximo ao valor certificado fornecido pela indústria farmacêutica. Estes resultados demonstraram a precisão e confiabilidade do método para a determinação de antimônio em diferentes amostras. Além disto, a técnica mostrou ser mais fácil, rápida, não apresentando problemas na preparação das amostras, fator decisivo para a escolha da metodologia, uma vez que diferentes matrizes foram avaliadas. Também apresenta a capacidade de determinação multielementar, alta precisão e preço moderado comparado a um método analítico convencional. Por conseguinte, todas as determinações realizadas para quantificar o antimônio nos lipossomas foram feitas pela AAN.

Uma ampla variedade de estudos tem sido reportada para a determinação de antimônio em amostras biológicas usando a AAN (Saiki et al., 1998; Vasconcelos et al., 2001), salientando a viabilidade desta técnica na quantificação de traços de elementos em diversos materiais.

Dorea e colaboradores $(1987,1989)$ relataram a utilização da AAN na determinação de antimônio em pequenas quantidades nas amostras de cabelo de indivíduos portadores de Leishmaniose e, tratados com diferentes concentrações de antimoniato de meglumina. Nestes estudos, os autores concluíram que a AAN foi adequada na detecção de diferenças entre os níveis de terapia com antimônio, sendo viável para o monitoramento e diferenciação da exposição ao medicamento em pacientes sob tratamento. Posteriormente, o mesmo grupo (1990) estudou a retenção de antimônio na pele de indivíduos com Leishmaniose e tratados com antimoniato de meglumina utilizando a AAN.

Smith e colaboradores (1986) monitoraram o clareamento do estibogluconato de sódio livre e encapsulado em lipossoma no fígado de rato perfundido usando a AAN. Os autores concluíram que a AAN é uma técnica com alta sensibilidade e acurácia, a qual pode rapidamente ser aplicada na análise da cinética de distribuição dos compostos antimoniais e em um grande número de amostras. Verificaram a simplicidade da preparação das amostras, a possibilidade da utilização de materiais sólidos ou líquidos e que a contaminação bacteriana não influencia nas medidas.

\subsubsection{Antimoniato de Meglumina Irradiado com Nêutrons (AMI)}

A determinação química de pequenas quantidades de antimônio nos tecidos e fluidos corpóreos tem sido insatisfatória, devido a baixa acurácia e viabilidade dos 
métodos analíticos. Compostos sintetizados com antimônio radioativo usados para a avaliação do metabolismo de antimônio no corpo apresantam-se como uma ferramenta útil para esta finalidade. Recentemente nosso grupo sugeriu, pela primeira vez, a utilização da irradiação em reator nuclear para a produção de compostos radioativos de antimônio pentavalente, especificamente do antimoniato de meglumina, para realização de estudos de biodistribuição em animais, a fim de aprimorar seus dados farmacológicos ainda não esclarecidos (Borborema et al., 2005 a). Os isótopos radioativos de um elemento tem as mesmas propriedades químicas de seu isótopo estável. As característica físicas estão alteradas, de maneira que em poucos minutos sua quantidade pode ser detectada. Estas propriedades conduziram ao uso das substâncias radioativas nos estudos biológicos.

Para a produção de radiotraçadores de antimônio, amostras de antimoniato de meglumina foram irradiadas num reator nuclear. Este procedimento permitiu a obtenção de um composto com elevada pureza radionuclídica, apresentada de forma qualitativa através da identificação do espectro de raios gamas correspondente apenas aos picos de decaimento dos radioisótopos: ${ }^{122} \mathrm{Sb}$ e ${ }^{124} \mathrm{Sb}$ (TAB. 14). Estes radioisótopos decaem pela emissão de raios gama e os principais picos de energia gama emitidos estão dentro de uma faixa de energia entre 564 a $723 \mathrm{keV}$, permitindo a utilização de um detector de radiação gama, para a identificação da biodistribuição do radiotraçador em diferentes sistemas biológicos.

TABELA 14 - Espectros de raios gama do ${ }^{122} \mathrm{Sb}$ e ${ }^{124} \mathrm{Sb}$, determinados por meio de espectroscopia- $\gamma$, utilizando um detector de Ge hiper puro.

\begin{tabular}{cccc}
\hline Radioisótopos & Meia vida física $\left(\mathbf{T}_{\mathbf{1 / 2}}\right)$ & Energia $\boldsymbol{\gamma}(\mathbf{k e V})$ & Abundância $(\boldsymbol{\%})$ \\
\hline \multirow{2}{*}{2,7 dias } & 563,99 & 69,30 \\
& & 692,94 & 3,78 \\
\hline${ }^{122} \mathrm{Sb}$ & 602,66 & 97,80 \\
& & 645,77 & 7,38 \\
& & 668,87 & - \\
& & 709,26 & 1,35 \\
${ }^{124} \mathrm{Sb}$ & 70,2 dias & 722,73 & 2,40 \\
& & 790,46 & 10,76 \\
& & 968,31 & 0,74 \\
& & 1045,15 & 1,80 \\
& & 1368,43 & 1,84 \\
& & 1691,51 & 2,62 \\
& & & 47,34 \\
\hline
\end{tabular}


Os resultados da atividade no final da irradiação dos dois radioisótopos de antimônio são mostrados na FIG. 16. Entre os diferentes períodos de tempo de irradiação e fluxo de nêutrons foi possível verificar a linearidade da atividade no processo de produção dos radioisótopos, com adequado coeficiente de correlação. Utilizando um fluxo de nêutrons maior $\left(1,1 \times 10^{13} \mathrm{n} / \mathrm{cm}^{2} \mathrm{~s}\right)$ num período de tempo curto (5 minutos) foi obtida cerca de dez vezes mais atividade comparada quando a irradiação ocorreu com um fluxo de nêutrons menor $\left(1,0 \times 10^{12} \mathrm{n} / \mathrm{cm}^{2} \mathrm{~s}\right)$ no mesmo período de tempo. A irradiação do antimoniato de meglumina durante um período de tempo intermediário (15 minutos) foi suficiente para a produção de radioisótopos de Sb com atividade específica satisfatória para o uso deste composto como radiotraçador em estudos biológicos.
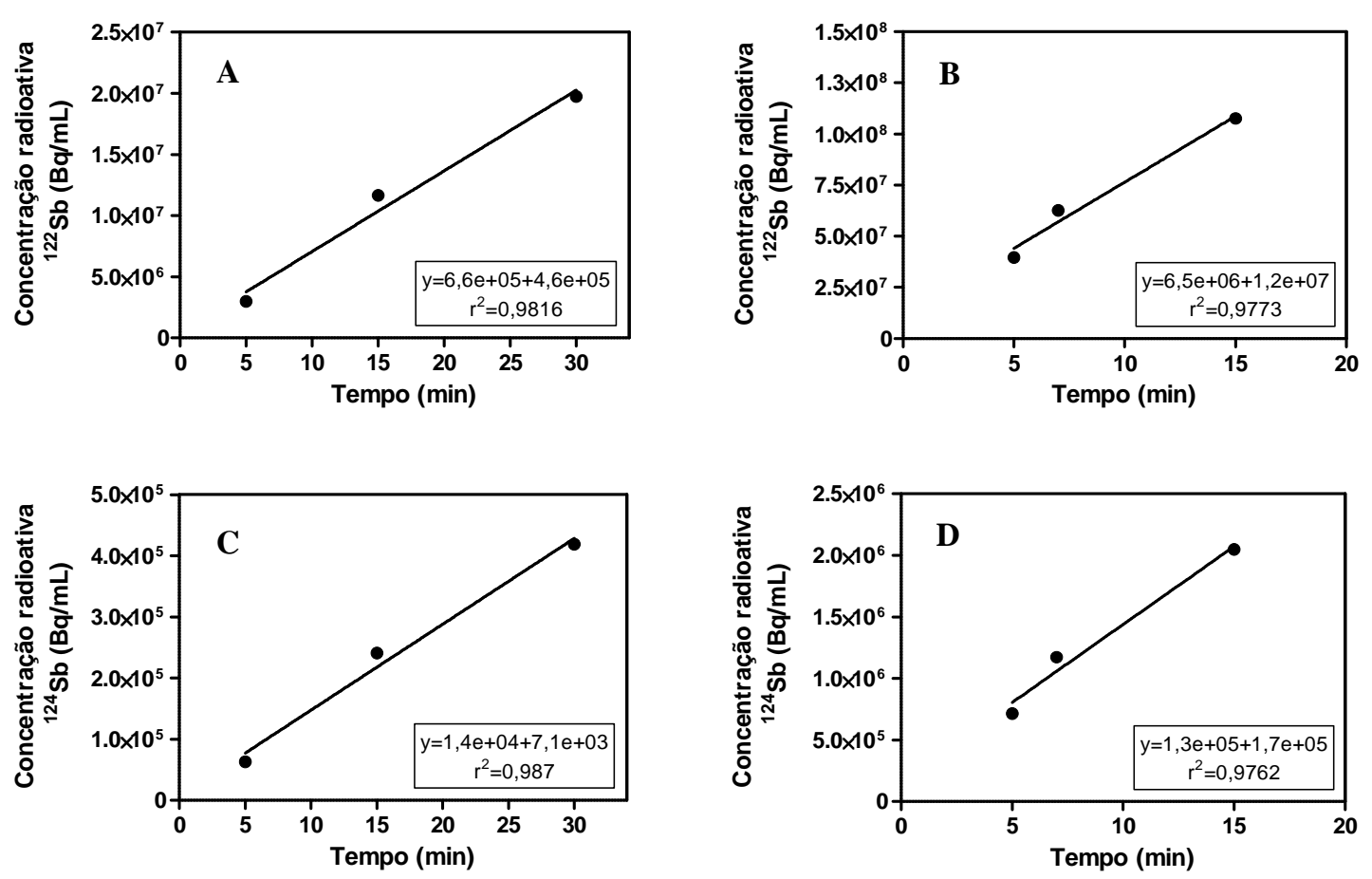

FIGURA 16 - Análise dos radioisótopos de antimônio produzidos no Reator Nuclear IEAR1m (IPEN/CNEN-SP). A e C = fluxo de nêutrons térmicos de $1,0 \times 10^{12}$ $\mathrm{n} / \mathrm{cm}^{2} \mathrm{~s} ; \mathrm{B}$ e $\mathrm{D}=$ fluxo de nêutrons térmicos de $1,1 \times 10^{13} \mathrm{n} / \mathrm{cm}^{2} \mathrm{~s}$.

Após estas caracterizações, foi determinado o melhor protocolo de irradiação com um fluxo de nêutrons térmicos entre $0,8-1,0 \times 10^{12} \mathrm{n} / \mathrm{cm}^{2} \mathrm{~s}$ durante 15 minutos para todas as análises subseqüentes. As amostras de AMI apresentaram adequada concentração radioativa (TAB. 15). O radioisótopo com maior atividade no final da irradiação foi o 
${ }^{122} \mathrm{Sb}$, assim as medidas de radiação foram realizadas com base no seu pico de energia gama.

TABELA 15 - Determinação da concentração radioativa dos radioisótopos de $\mathrm{Sb}$ produzidos no Reator Nuclear IEA-R1m (IPEN/CNEN-SP). Os dados são apresentados como a média \pm desvio padrão $(n=4)$.

\begin{tabular}{cc}
\hline Radioisótopos & Concentração Radioativa (Bq/mL) \\
\hline${ }^{122} \mathrm{Sb}$ & $(3,5 \pm 4,2) \times 10^{7}$ \\
${ }^{124} \mathrm{Sb}$ & $(4,9 \pm 6,4) \times 10^{5}$ \\
\hline
\end{tabular}

Como verificado anteriormente, o antimoniato de meglumina irradiado apresentou uma ligeira alteração colorimétrica, indicando provável polimerização da meglumina (Borborema et al., 2005 a). O mesmo efeito também foi observado quando o antimoniato de meglumina foi exposto a condições inadequadas de temperatura e luminosidade, em más condições de armazenagem (Romero et al., 1996). Este composto é obtido sinteticamente por uma reação do antimônio pentavalente com a N-metilmeglumina e a extensa polimerização na composição do antimoniato de meglumina pode influenciar na farmacocinética de liberação do fármaco, na captação pelo sistema mononuclear fagocitário e na distribuição intracelular do antimônio pentavalente (Roberts et al., 1998).

Recentemente, foi demonstrado que a formulação de antimoniato de meglumina irradiada com nêutrons apresentou eficácia similar ao fármaco nativo tanto no tratamento in vitro de macrófagos peritoneais infectados com L. (L.) chagasi como no tratamento in vivo de animais infectados com L. (L.) chagasi, comprovando a manutenção de sua atividade biológica, após o processo de irradiação (Borborema, 2005).

Brady e colaboradores (1945) produziram antimônio radioativo através do bombardeamento de antimônio trivalente com deuterons em cíclotron. Em seguida, utilizaram o antimônio radioativo na síntese de diferentes compostos contendo $\mathrm{Sb}(\mathrm{III})$ : tártaro emético, trióxido de antimônio e xilitol antimoniato de sódio. Cachorros naturalmente infectados com Dirofilaria immitis, agente causador da filariose, foram tratados com as soluções e utilizando o traçador radioativo puderam determinar o padrão de biodistribuição dos diferentes compostos (Cowie et al., 1945). Os autores concluíram que esta metodologia apresenta um papel potencial nos estudos toxicológicos de fármacos que não conseguem ser determinadas em quantidades pequenas por outros métodos.

Berman e colaboradores (1987) utilizaram uma formulação de estibogluconato de sódio marcada com radioisótopo de antimônio $\left({ }^{125} \mathrm{Sb}\right.$-Pentostam) para estudar a 
captação do medicamento em formas amastigotas e promastigotas de Leishmania mexicana e em células macrofágicas. Posteriormente, o mesmo grupo usou o ${ }^{125} \mathrm{Sb}$-Pentostam para examinar as propriedades químicas do fármaco e sua interação com amastigotas de Leishmania mexicana (Berman et al., 1988).

Os estudos avaliados demonstraram claramente a viabilidade da utilização de radiotraçadores de antimônio na caracterização química dos medicamentos baseados em agentes antimoniais, bem como, mostraram-se como uma metodologia bastante vantajosa para a determinação do perfil farmacológico destes fármacos.

\subsection{Caracterização dos Lipossomas}

A caracterização detalhada da estrutura dos lipossomas é importante, uma vez que ela fornece as informações sobre as diferenças estruturais causadas por alterações nos métodos de preparação e na composição de lipídios. Essas diferenças afetam o comportamento das vesículas in vitro (estabilidade) e in vivo (distribuição) (Jousma et al., 1987). Além disso, as características físico-químicas dos lipossomas podem fortemente influenciar sua função. Portanto, uma definição adequada da estrutura é essencial para obter resultados repetíveis, um pré-requisito para o sucesso da introdução dos lipossomas na terapia.

\subsubsection{Quantificação de fosfolipídios}

Os fosfolipídios puderam ser determinados por um método colorimétrico desenvolvido pela formação de um complexo entre o fosfolipídio e o ferrotiocianato de amônio, sendo um método simples, rápido e vantajoso por não necessitar de processos de digestão ácida e nem aquecimento a elevadas temperaturas, além do que o fosfato inorgânico não interfere no ensaio (Stewart, 1980).

A curva de calibração para fosfatidilcolina mostrou excelente linearidade de 0,999, y= 5,526x +0,0039 (FIG. 17). 


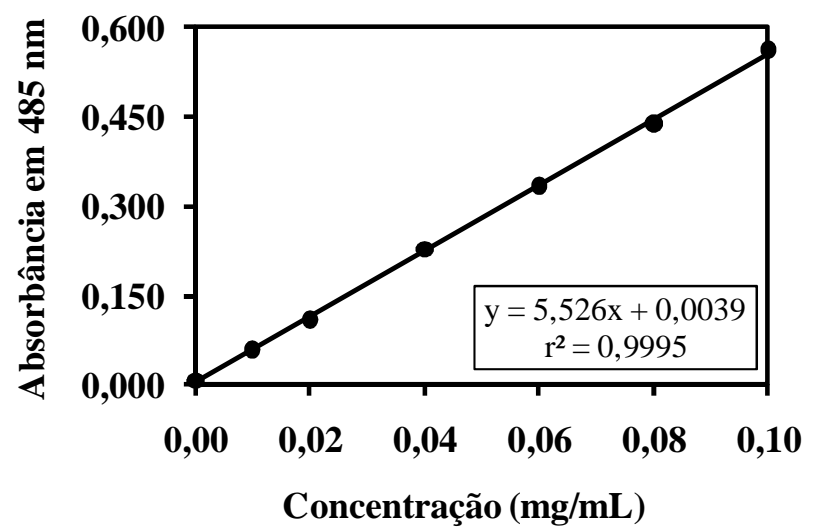

FIGURA 17 - Curva de calibração da fosfatidilcolina por espectrofotometria usando ferrotiocianato de amônio num comprimento de onda de $485 \mathrm{~nm}$.

Na quantificação de fosfolipídios nas formulações de lipossomas foi possível recuperar ao final do procedimento $38 \pm 16 \mathrm{mg}(\mathrm{n}=4)$ de fosfolipídio para o AM-FEL e 43 $\pm 4 \mathrm{mg}(\mathrm{n}=4)$ de fosfolipídio para o AM-FDEL, representando o rendimento do processo de 45 e $51 \%$, respectivamente de fosfolipídios. Nos lipossomas elaborados pelo método FEL, foram observados maiores perdas e diferenças entre as diversas amostras, especialmente durante a etapa de extrusão através de membrana, a qual dificulta a repetibilidade da técnica. No entanto, os lipossomas preparados pelo método FDEL apresentaram menores perdas e maior repetibilidade no procedimento. A determinação de fosfolipídios foi realizada em todas as etapas da confecção dos lipossomas, a separação do fármaco não encapsulada nos lipossomas FDEL foi realizada por centrifugação, a quantificação nos sobrenadantes obtidos com as lavagens dos lipossomas indicou que o processo de centrifugação não causou danos às vesículas, conforme confirmado por microscopia eletrônica (item 4.2.2), visto que a quantidade de fosfolipídios determinada foi bastante pequena, sugerindo que as vesículas não se rompem com o processo.

\subsubsection{Determinação do tamanho dos lipossomas}

Como as propriedades dos lipossomas em sistemas in vitro e in vivo são fortemente dependentes de seu tamanho, composição e lamelaridade, o tamanho médio e a homogeneidade das formulações lipossomal foram determinados como controle de qualidade da produção. Na TAB. 16 são mostrados os resultados do diâmetro médio dos lipossomas por FTL em várias etapas da preparação. 
TABELA 16 - Avaliação do diâmetro médio dos lipossomas contendo antimoniato de meglumina (AM-FTL) após as diferentes etapas de preparação. Os resultados são mostrados como média ponderada por análise de distribuição de Nicomp num determinador de tamanho de partículas por espalhamento de luz laser. MLV = vesículas multilamelares; FT = após o descongelamento-congelamento; SUV = vesículas unilamelares pequenas; $\mathrm{AD}=$ depois da diálise.

\begin{tabular}{ccccccc}
\hline Etapas & $\begin{array}{c}\text { Pico 1 } \\
(\mathbf{n m})\end{array}$ & $\begin{array}{c}\text { Partículas } \\
(\boldsymbol{\%})\end{array}$ & $\begin{array}{c}\text { Pico 2 } \\
(\mathbf{n m})\end{array}$ & $\begin{array}{c}\text { Partículas } \\
(\boldsymbol{\%})\end{array}$ & $\begin{array}{c}\text { Pico 3 } \\
(\mathbf{n m})\end{array}$ & $\begin{array}{c}\text { Partículas } \\
(\boldsymbol{\%})\end{array}$ \\
\hline MLV & 233 & 56 & 388 & 31 & 1782 & 13 \\
FT & 251 & 78 & 1336 & 22 & - & - \\
SUV & 161 & 88 & 422 & 12 & - & - \\
AD & 120 & 78 & 325 & 22 & - & - \\
\hline
\end{tabular}

Os resultados foram obtidos com um determinador de tamanho de partículas por espalhamento de luz laser. Foi verificado que a homogeneidade de tamanho de partícula aumentou após o processo de descongelamento-congelamento. A redução de tamanho e a maior homogeneidade foram conseguidas por extrusão através de membranas de policarbonato. Múltiplas extrusões provocaram uma forte redução no tamanho das partículas do que o processo de descongelamento-congelamento.

Na TAB. 17 é apresentada a avaliação do diâmetro médio de diferentes lipossomas preparados por FTL, após a separação do fármaco não encapsulada por diálise. Todos os lipossomas revelaram um tamanho médio inferior a $150 \mathrm{~nm}$. Foi verificado que o diâmetro médio de lipossomas contendo fosfatidilserina é menor que dos lipossomas convencionais, sem fosfatidilserina.

TABELA 17 - Avaliação do diâmetro médio de diferentes formulações de lipossomas (FTL) utilizando um determinador de tamanho de partículas por espalhamento de luz laser.

\begin{tabular}{cc}
\hline Lipossomas & Diâmetro médio $(\mathbf{n m})$ \\
\hline AM-FTL & $142 \pm 61$ \\
AM-PS-FTL & $141 \pm 96$ \\
Sb(III)-FTL & $127 \pm 58$ \\
FTL & $155 \pm 54$ \\
PS-FTL & $86 \pm 36$ \\
Dil-FTL & $129 \pm 60$ \\
Dil-AM-FTL & $142 \pm 73$ \\
Dil-PS-FTL & $95 \pm 32$ \\
\hline
\end{tabular}


A caracterização dos lipossomas por microscopia eletrônica de transmissão usando a técnica de coloração negativa permitiu a visualização de detalhes estruturais, a determinação do tamanho e das propriedades morfológicas das vesículas. Na FIG. 18 são mostradas micrografias de diferentes formulações de lipossomas. Os dados obtidos por esta técnica revelaram que as vesículas são multilamelares e apresentam uma forma ovalada com uma larga distribuição do tamanho.
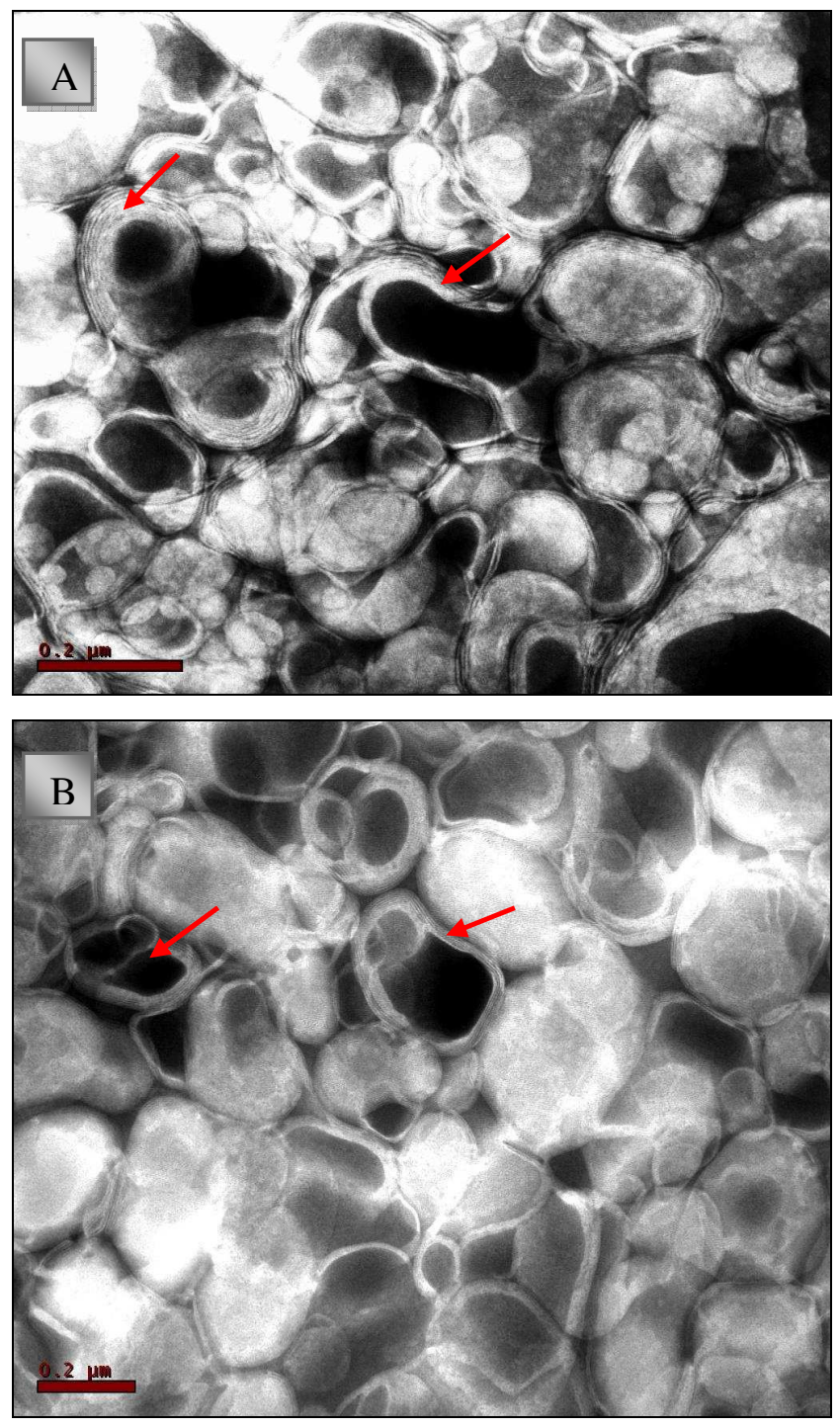

FIGURA 18 - Micrografia de lipossomas por microscopia eletrônica de transmissão usando a técnica de coloração negativa. $\mathrm{A}=$ antimoniato de meglumina encapsulado em lipossoma liofilizado vazio (AM-FDEL); B = antimoniato de meglumina encapsulado em lipossoma por extrusão através de membrana de policarbonato (AM-FEL). As setas indicam as vesículas multilamelares (MLV). 
Chetanachan e colaboradores (2008) demonstraram a viabilidade da microscopia eletrônica de transmissão com coloração negativa na investigação das características morfológicas dos lipossomas multilamelares.

As formulações de lipossomas (AM-FDEL e AM-FEL) apresentam vesículas com tamanho médio menor que $200 \mathrm{~nm}$, mas o AM-FDEL mostrou maior homogeneidade no tamanho do que o AM-FEL (FIG. 19).

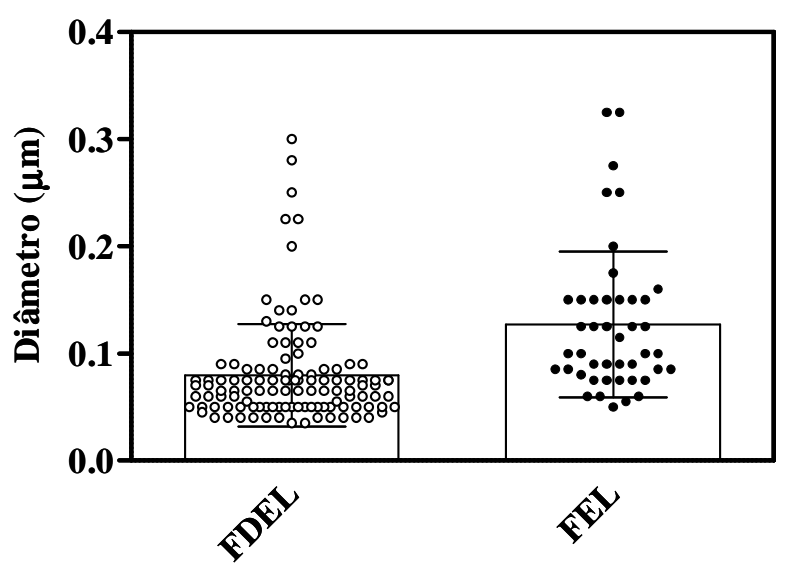

FIGURA 19 - Avaliação do diâmetro médio de diferentes formulações de lipossomas por microscopia eletrônica de transmissão usando a técnica de coloração negativa. AM-FDEL $=$ antimoniato de meglumina encapsulado em lipossoma liofilizado vazio; $\mathrm{AM}-\mathrm{FEL}=$ antimoniato de meglumina encapsulado em lipossoma por extrusão através de membrana de policarbonato.

A determinação do tamanho das vesículas serve também como um indicador de alterações na estabilidade física dos lipossomas. Os lipossomas preparados pelo método de liofilização (FDEL) resultaram numa suspensão de tamanho uniforme de vesículas multilamelares. O processo parece não ter afetado o tamanho das partículas após a reidratação dos lipossomas, indicando ausência da fusão de vesículas. Isto pode ser decorrente da utilização da sacarose, como crioprotetor, uma vez que já está bem descrito que o açúcar tem a capacidade de prevenir a fusão das vesículas durante a liofilização dos lipossomas (Ausborn et al., 1994). Os crioprotetores têm a habilidade de interagir com o grupo de cabeça polar dos fosfolipídios e estabilizar a membrana quando a água estabilizante da bicamada foi removida por sublimação. Eles formam uma matriz de vidro amorfa durante o congelamento e exibem baixa mobilidade molecular após a secagem. 
Esta constituição é considerada essencial para prevenção do dano, por fusão e formação de cristal, as quais causam a liberação do fármaco encapsulado (Glavas-Dodov et al., 2005).

Os resultados apresentados para os lipossomas por extrusão (FEL e FTL) corroboram com os achados de Olson e colaboradores (1979). Os autores realizaram a extrusão seqüencial de vesículas multilamelares através de membrana de policarbonato e verificaram a redução do tamanho médio e da heterogeneidade das vesículas lipídicas. Além disso, os lipossomas mostraram um tamanho de diâmetro médio semelhante ao tamanho do poro da membrana de policarbonato usada na extrusão.

A extrusão dos lipossomas através de membrana de policarbonato representa uma abordagem vantajosa para a produção de vesículas multilamelares com distribuição de tamanho bem caracterizado e definido. O processo de extrusão é conveniente, facilmente reproduzível, não introduz impurezas nas vesículas e não induz o colapso dos lipídios. Além do mais, as vesículas podem ser extruídas através de membranas de 0,22 $\mu \mathrm{m}$ permitindo a produção de uma preparação estéril para uso in vivo.

As vesículas por extrusão servem como um atrativo carreador de compostos que não podem ser expostos aos solventes orgânicos, os quais são usados na técnica de injeção de éter ou na técnica de evaporação em fase reversa, mais ainda a extrusão pode ser usada para produzir preparações de vesículas mais uniformes formadas por ambos os métodos anteriores (Szoka \& Papahadjopoulos, 1978).

O tamanho das vesículas bem como a sua distribuição em cada preparação é de grande relevância, pois afeta de forma direta a biodistribuição e o tempo de circulação dos lipossomas, assim como seu processo de captura pelas células do sistema mononuclear fagocitário (SMF). A velocidade de liberação do princípio ativo pode ser controlada pela manipulação tanto da composição da membrana (influenciando a velocidade de degradação dos lipossomas) quanto do tamanho dos lipossomas (influenciando a eficiência de captura pelos macrófagos). Assim, lipossomas pequenos são capturados com menor eficiência que lipossomas grandes, permanecendo por mais tempo na circulação sanguínea e apresentam uma liberação mais prolongada (Frézard et al., 2005).

Neste trabalho foram produzidas formulações de lipossomas por diferentes metodologias apresentando tamanho médio de aproximadamente 150 a $200 \mathrm{~nm}$. O tamanho das vesículas lipídicas tem sido mostrado como excelente abordagem no direcionamento de fármacos ao SMF. Como demonstrado por Schettini e colaboradores (2006) lipossomas de tamanho reduzido $(400 \mathrm{~nm})$ contendo antimoniato de meglumina apresentaram aumento no direcionamento para a medula óssea de cachorros com leishmaniose visceral e alta 
retenção de antimônio nesse tecido quando comparado com o tratamento com o fármaco livre e com relação à formulação lipossomal com tamanho de vesículas maiores (1200 nm). Além disso, lipossomas pequenos $(100 \mathrm{~nm})$ contendo antimonial foram mais eficazes na redução do número de parasitas Leishmania na medula óssea de camundongos do que os lipossomas de tamanho maior (Carter et al., 1989).

Tem sido demonstrado que vesículas multilamelares grandes $(3 \mu \mathrm{m})$ aumentam o direcionamento de fármacos para o pulmão, já vesículas unilamelares pequenas exibiram aumento na medula óssea. Agentes terapêuticos podem ser direcionados aos parasitas que residem nas células do SMF, nesta abordagem parece ser mais eficiente o uso de lipossomas com tamanho médio $(0,1$ a $1 \mu \mathrm{m})$ e compostos por fosfolipídios de carga negativa (Mayer et al., 1986).

\subsubsection{Determinação da Eficiência de Encapsulação (Ee)}

A porcentagem de fármaco encapsulada nos lipossomas foi determinada para poder comparar a atividade biológica das preparações de lipossomas com o fármaco livre e conhecer a eficiência de encapsulação das diferentes formulações. Na TAB. 18 estão resumidos os resultados, mostrando a concentração inicial das soluções de fármaco usada na preparação dos lipossomas, a concentração final após a separação do fármaco não encapsulado e a eficiência de encapsulação.

TABELA 18 - Avaliação da concentração inicial das soluções de fármaco usadas na preparação de lipossomas, da concentração final após separação do fármaco não encapsulado e da eficiência de encapsulação (Ee). Os dados são apresentados como a média \pm desvio padrão $(n=4)$ ou média $(n=1)$. n.d. = não determinado.

\begin{tabular}{ccccc}
\hline Amostras & $\begin{array}{c}\text { Razão }_{\mathbf{i}} \\
\mathbf{S b} / \mathbf{L P}(\mathbf{m} / \mathbf{m})\end{array}$ & $\begin{array}{c}\mathbf{C o n c}_{\mathbf{f}} \\
(\mathbf{m g} / \mathbf{m L})\end{array}$ & $\begin{array}{c}\text { Ee } \\
\mathbf{( \% )}\end{array}$ & $\begin{array}{c}\text { Recuperação } \\
(\mathbf{\%})\end{array}$ \\
\hline AM-FTL & 0,04 & 3,0 & 25 & n.d. \\
AM-PS-FTL & 0,04 & 4,1 & 38 & n.d. \\
Sb(III)-FTL & 0,04 & 1,8 & 17 & n.d. \\
AM-FEL & 0,74 & $11 \pm 7$ & $11 \pm 3$ & $52 \pm 9$ \\
AM-FDEL & 0,58 & $3 \pm 1$ & $20 \pm 10$ & $90 \pm 13$ \\
Sb(V)-FEL & 0,46 & 1,5 & 7 & 59 \\
Sb(III)-FDEL & 0,12 & 0,5 & 15 & 110 \\
\hline
\end{tabular}


Estes resultados foram obtidos através da técnica AAN, avaliando a quantidade de antimônio presente nas diversas etapas das preparações. A mesma avaliação foi realizada por outras técnicas, tais como LCV, VPD e ICP-OES, no entanto, os resultados não foram reprodutíveis devido a problemas na preparação e digestão de amostras. A técnica de AAN não apresentou nenhum desses problemas e não foi necessária a digestão das amostras.

Os lipossomas produzidos pelo método FDEL mostraram maior eficiência de encapsulação, além do que apresentaram os mais altos níveis de recuperação do fármaco, cerca de $100 \%$, comparados com os lipossomas elaborados pelo método FEL. As diferentes formulações (FDEL e FEL) foram desenvolvidas com a mesma razão molar de lipídios, porém houve uma significativa diferença na concentração de antimônio utilizado. Foi verificado que a relação antimônio/lipídio (massa/massa) está diretamente relacionada com a eficiência de encapsulação, quanto menor a razão Sb/LP maior a eficiência, quanto maior a razão menor a eficiência (TAB. 18).

Para efetuar o estudo comparativo entre diferentes formulações e metodologias, lipossomas com diferentes composições e seguindo o mesmo método foram preparados, bem como, lipossomas com a mesma composição e variando o procedimento de elaboração. Como apresentado na FIG. 20, a análise comparativa entre os lipossomas preparados pelo método FTL, revelou que a eficiência de encapsulação foi mais elevada quando as vesículas continham fosfolipídio negativamente carregado, como a fosfatidilserina (AM-PS-FTL), apresentando $38 \%$, de encapsulação enquanto os lipossomas preparados sem fosfatidilserina (AM-FTL) apresentaram uma eficiência de encapsulação de $25 \%$, sendo que os níveis mais baixos foram obtidos quando o sal de $\mathrm{Sb}$ (III) foi encapsulado em lipossomas (Sb(III)-FTL), apresentando $17 \%$ de encapsulação. 


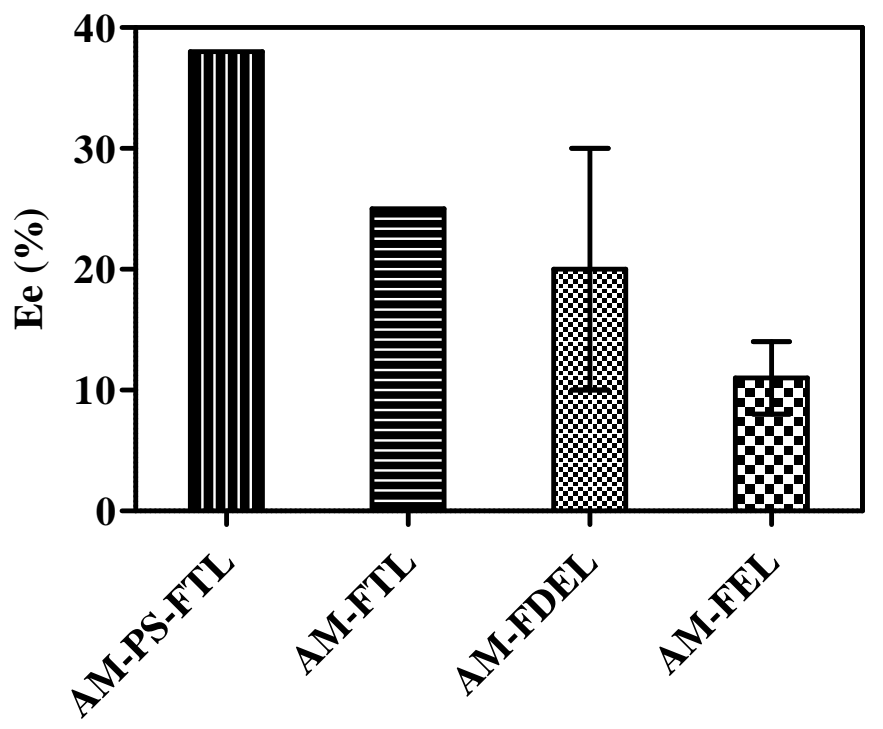

FIGURA 20 - Avaliação da eficiência de encapsulação (Ee). Os dados são apresentados como a média \pm desvio padrão $(n=4)$ ou média $(n=1)$.

A determinação do volume do fármaco encapsulado prediz a eficiência de encapsulação que, por sua vez, é fundamental na regulação da taxa de liberação, biodistribuição e farmacocinética do sistema lipossomal. A eficiência de encapsulação de fármacos hidrossolúveis depende da capacidade das vesículas em capturar a solução aquosa na qual o princípio ativo está dissolvido durante a formação das vesículas. Nesse caso, a taxa de encapsulação fica restrita ao volume aquoso encerrado no compartimento interno.

Uma consideração importante na determinação de um sistema lipossomal efetivo é a eficiência de encapsulação da formulação, já que a concentração de fármaco que um lipossoma pode encapsular representa a concentração de fármaco que poderá ser direcionada à célula alvo. Neste estudo foi observado que a eficiência de encapsulação variou entre os métodos avaliados. O AM-FEL, AM-FDEL e AM-FTL apresentaram 11, 20 e $38 \%$ de eficiência de encapsulação, respectivamente. Do mesmo modo, Frézard e colaboradores (2005) registram que a taxa de encapsulação máxima do antimoniato de meglumina em formulações constituídas de vesículas multilamelares (MLV) foi de $7 \%$, já as formulações liofilizadas (FDEL) atingiram o máximo de $42 \%$.

Os resultados obtidos neste estudo demonstraram que o antimoniato de meglumina pode ser eficientemente encapsulado em lipossomas constituídos de fosfatidilcolina: fosfatidilserina: colesterol (4:1:5) preparados por diferentes metodologias. 
Como mostrado à eficiência de encapsulação foi fortemente afetada pela concentração de lipídios, o uso de altas concentrações aumentou a eficiência de encapsulação do agente terapêutico. O uso de fosfolipídio negativamente carregado também demonstrou associação com a elevação da taxa de encapsulação. Uma das hipóteses esta relacionada ao aumento do volume aquoso do lipossoma causado pela fosfatidilserina, resultante da repulsão de carga separando as bicamadas lipídicas adjacentes (Uhumwangho \& Okor, 2005).

A taxa de clareamento e a biodistribuição dos lipossomas são influenciadas pela composição da vesícula, tamanho, dose e via de administração. Assim, a escolha do melhor sistema se torna imperativo. A carga de superfície dos lipossomas apresenta papel importante na eficiência de encapsulação de diferentes agentes terapêuticos e na interação com as células alvo. Neste estudo foram utilizados lipossomas constituídos com fosfolipídio negativamente carregado - fosfatidilserina (FDEL, FEL, PS-FTL), uma vez que tem sido demonstrado que vesículas com carga negativa são rapidamente capturadas pelas células do SMF do que vesículas com carga positiva ou neutra (Mayer et al., 1986; Fidler, 1988). A captura de lipossomas carregados negativamente no baço foi aproximadamente duas vezes maior do que com os carregados positivamente (Banerjee, 2001).

A carga de superfície dos lipossomas pode contribuir para a internalizaçãoassociação com macrófagos. Tempone e colaboradores (2008) revelaram alta eficácia na redução da carga parasitária no fígado de camundongos tratados com antimoniato de meglumina encapsulado em lipossomas contendo fosfatidilserina, reduzindo em 133 vezes a dose de antimônio total quando comparado com o fármaco livre.

\subsubsection{Determinação da Estabilidade das Formulações Lipossomais}

A estabilidade dos lipossomas é um importante fator no desenvolvimento de um sistema de entrega de fármacos efetivo. Por essa razão, a estabilidade das formulações lipossomais foi avaliada em diferentes ambientes para simular as condições fisiológicas. Assim, as formulações lipossomais foram incubadas em solução de glicerol a $4{ }^{\circ} \mathrm{C}$ (temperatura de armazenamento) e em plasma de hamster a $37^{\circ} \mathrm{C}$ (temperatura corpórea).

Como apresentado na FIG. 21, ambas as formulações lipossomais mostraram maior retenção do fármaco quando incubadas em glicerol comparando com a capacidade de retenção em plasma. No entanto, a formulação de antimoniato de meglumina 
encapsulado em lipossoma do tipo FEL incubada em glicerol reteve mais antimônio e apresentou maior estabilidade durante o período de tempo observado. No caso da incubação em plasma, os lipossomas exibiram praticamente a mesma capacidade de retenção, cerca de $90 \%$ do fármaco estava encapsulado nos lipossomas após de $2 \mathrm{~h}$ de incubação.
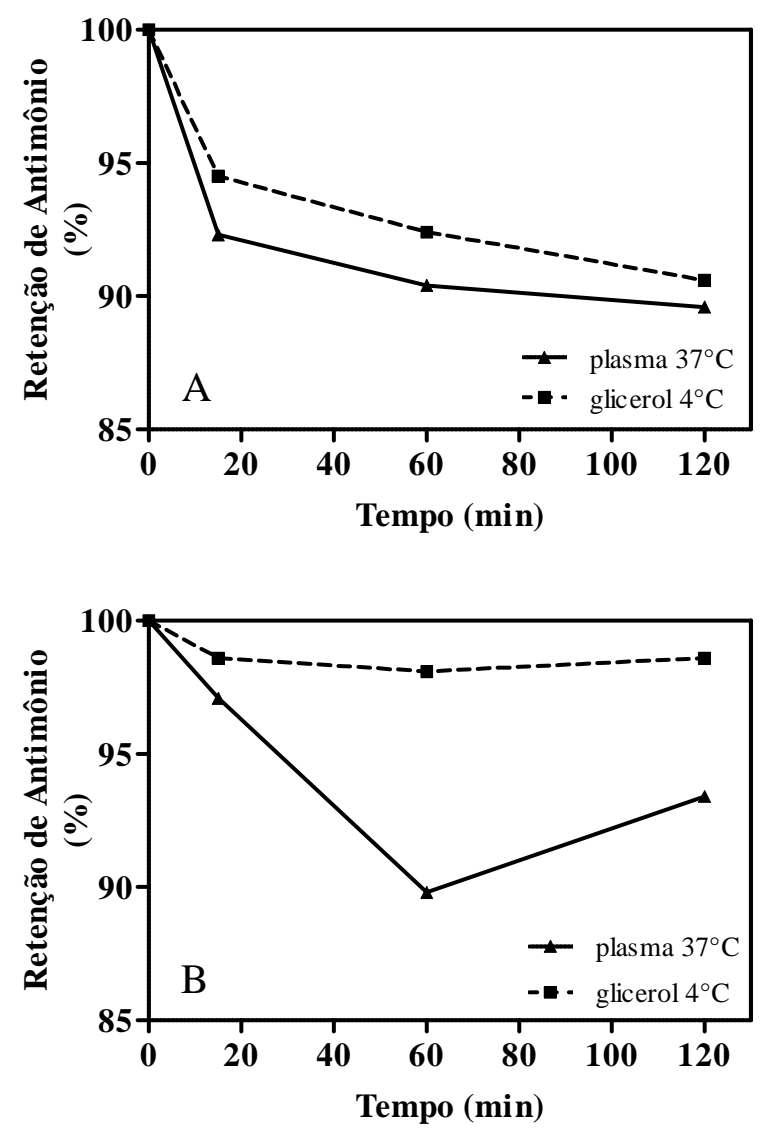

FIGURA 21 - Avaliação da estabilidade in vitro das formulações de lipossomas. A = AMFDEL = antimoniato de meglumina encapsulado em lipossoma liofilizado vazio; $\mathrm{B}=\mathrm{AM}-\mathrm{FEL}=$ antimoniato de meglumina encapsulado em lipossoma por extrusão através de membrana de policarbonato.

Os lipossomas interagem com pelo menos dois grupos distintos de proteínas plasmáticas: as lipoproteínas de alta densidade e as opsoninas, as quais pela adsorção na superfície das vesículas intercedem sua endocitose pelas células do SMF. A interação entre as vesículas lipídicas e os componentes do plasma pode desestabilizar os lipossomas resultando em maior liberação do fármaco (Frézard, 1999). Este fenômeno parece explicar a menor capacidade de retenção dos lipossomas quando incubados em plasma. 
A estabilidade dos lipossomas é essencial na eficácia do sistema de entrega de fármacos, bem como o perfil de retenção determina a quantidade e o tempo de liberação do fármaco encapsulado. Estes parâmetros estão diretamente relacionados com diversos fatores, tais como: tamanho das vesículas, composição lipídica, temperatura de transição de fase $\left(\mathrm{T}_{\mathrm{c}}\right)$ e carga dos lipídios (Anderson \& Omri, 2004). Além disso, a estabilidade in vitro dos lipossomas tem importante implicação no uso in vivo, já que bons resultados em condições biológicas são vitais para o desenvolvimento de um sistema potente que permita direcionar a fármaco ao local alvo, com resposta satisfatória.

\subsubsection{Lipossoma Radiomarcado (FDEL-AMI)}

A preparação de lipossomas radiomarcados exige uma formulação simples, reprodutível, com adequada eficiência de encapsulação e principalmente, com alta recuperação do fármaco encapsulado. Desta forma, foi preconizado o método que consiste em liofilizar os lipossomas pequenos vazios sem o antimonial e reidratar o liofilizado com a solução antimonial (FDEL).

As preparações de lipossomas radiomarcados foram analisadas pela técnica de espectroscopia- $\gamma$ para a quantificação de antimônio. A determinação da radioatividade do antimônio foi realizada nas várias etapas da preparação. Na TAB. 19 são mostrados os resultados da avaliação da eficiência de encapsulação (Ee) do antimoniato de meglumina irradiado (AMI) encapsulado no FDEL.

TABELA 19 - Avaliação da Eficiência de Encapsulação (Ee) do antimoniato de meglumina irradiado encapsulado em lipossomas (FDEL-AMI). Os dados são apresentados como a média \pm desvio padrão $(\mathrm{n}=4)$.

\begin{tabular}{ccccc}
\hline Amostra & $\begin{array}{c}\text { Razão } \\
\text { Sb/LP }(\mathbf{m} / \mathbf{m})\end{array}$ & $\begin{array}{c}\text { Sb Encapsulado } \\
(\mathbf{m g})\end{array}$ & $\begin{array}{c}\text { Ee } \\
(\boldsymbol{\%})\end{array}$ & $\begin{array}{c}\text { Recuperação } \\
(\mathbf{\%})\end{array}$ \\
\hline FDEL-AMI & 0,6 & $6 \pm 2$ & $10 \pm 3$ & $99 \pm 8$ \\
\hline
\end{tabular}

O método FDEL mostrou ser um procedimento simples, fácil, reprodutível e com excelente recuperação do fármaco, perto de $100 \%$, referente as soluções analisadas do fármaco encapsulado e não encapsulado. Estes resultados sugerem que o método FDEL é muito útil para preparação de lipossomas contendo fármacos radiomarcadas, uma vez que é possível reduzir a quantidade de fármaco utilizada e diminuir os rejeitos radioativos. Deve-se considerar que a utilização dos métodos convencionais, utilizando o sistema de 
extrusão através de membranas de policarbonato, torna-se inviável. Os agentes radioativos podem contaminar os equipamentos usados, necessitando aguardar a descontaminação (decaimento radioativo) para serem utilizados novamente, reduzindo a vida útil dos instrumentos e aumentando o intervalo das preparações.

Além disso, o método FDEL apresenta vantagens tecnológicas significativas sobre os convencionais, pois a preparação pode ser armazenada por tempo prolongado na forma liofilizada intermediária e reidratada apenas antes da utilização, aumentando a estabilidade da formulação e reduzindo a degradação físico-química do agente encapsulado, já que este não é submetido aos processos de sonicação, extrusão e liofilização.

\subsection{Estudos Biológicos}

\subsubsection{Determinação da Concentração Efetiva $50 \%\left(\mathrm{CE}_{50}\right)$ em Promastigotas de Leishmania}

A avaliação da atividade antileishmania dos compostos em promastigotas de $L$. (L.) chagasi e $L$. (L.) major está representada na TAB. 20. Foi observado que os parasitos não apresentam suscetibilidade ao antimoniato de meglumina livre, nem em sua forma

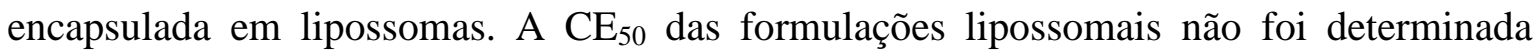
devido à maior concentração possível de ser utilizada para a análise in vitro não ser capaz de matar os parasitos. Estes resultados sugerem que a encapsulação dos antimoniais em lipossomas não alterou seu mecanismo de ação em promastigotas de Leishmania.

TABELA 20 - Avaliação da Concentração Efetiva 50 \% $\left(\mathrm{CE}_{50}\right)$ de diferentes formulações lipossomais em promastigotas de L. (L.) major e L. (L.) chagasi. IC95\%= Intervalo de Confiança 95\%; $(n=3)$.

\begin{tabular}{ccc}
\hline \multirow{2}{*}{ Amostras } & \multicolumn{2}{c}{$\mathbf{C E}_{\mathbf{5 0}}(\boldsymbol{\mu g} / \mathbf{m L} \mathbf{\text { IC }}$ 95\% $)$} \\
\cline { 2 - 3 } & $\boldsymbol{L .}(\boldsymbol{L}$.$) major$ & $\boldsymbol{L} .(\boldsymbol{L}$.$) chagasi$ \\
\hline AM-FTL & $>1000$ & n.d. \\
AM-PS-FTL & 1500 & n.d. \\
AM-FEL & n.d. & $>2000$ \\
AM-FDEL & n.d. & $12470(8810-17640)$ \\
AM & $>28000$ & $46,2(29,0-73,3)$ \\
Sb(III) & $2,0(1,5-2,6)$ & $67,6(53,0-86,2)$ \\
Sb(V) & $188,8(152,4-233,5)$ &
\end{tabular}


No entanto, ambas as espécies de Leishmania na forma promastigota mostraram maior suscetibilidade as soluções de sais de antimônio, contudo a solução de $\mathrm{Sb}(\mathrm{III})$ foi significativamente mais tóxica que a solução de $\mathrm{Sb}(\mathrm{V})$.

A baixa atividade do antimônio pentavalente nas formas promastigotas também foi mostrada por Roberts e colaboradores (1993) onde verificaram que frações do estibogluconato de sódio foram mais eficientes contra formas amastigotas de $L$. panamensis do que em formas promastigotas. Os autores ainda observaram que o tartarato de antimônio e potássio ( $\mathrm{Sb}(\mathrm{III})$ ) foi substancialmente mais eficiente que o estibogluconato de sódio tanto em formas promastigotas como em formas amastigotas. Preparações de antimônio trivalente e pentavalente livres e complexadas com manan, um polissacarídeo reconhecido por receptores de manose em macrófagos, foram incubadas com formas promastigotas e amastigotas onde verificaram que as preparações de antimônio trivalente foram mais ativas que as preparações de antimônio pentavalente contra ambas as formas. Também foi observado que as preparações de antimônio pentavalente são inerentemente menos tóxicas nas formas promastigotas (Roberts et al., 1995). Esses dados são consistentes com a hipótese de redução in vivo do antimônio pentavalente para sua forma trivalente ativa.

Quando promastigotas de L. donovani foram pré-tratadas com tartarato de antimônio e potássio e depois incubadas com estibogluconato de sódio foi verificado que o antimônio pentavalente reverteu a toxicidade do antimônio trivalente, sendo o antimônio pentavalente pouco eficiente contra a forma promastigota de Leishmania sp. (ShakedMishan et al., 2001). Os autores ainda concluíram que ambas as formas promastigotas e amastigotas acumulam antimônio pentavalente. A redução do $\mathrm{Sb}(\mathrm{V})$ para $\mathrm{Sb}(\mathrm{III})$, por processos enzimáticos ou não, ocorre em ambas as formas, porém a atividade redutora é mais intensa em amastigotas. Após a conversão, o Sb(III) é complexado com a tripanotiona e deslocado do parasito via transportadores específicos.

A baixa atividade antiparasitária do antimônio pentavalente nas formas promastigotas pode ser explicada pela necessidade de conversão do antimônio pentavalente para sua forma trivalente mais tóxica, que parece ser dependente de um mecanismo enzimático, com base na participação de enzimas do sistema de proteção contra danos oxidativos, a tripanotiona, um tiol de baixa massa molecular, presente em quantidade muito maior na forma intracelular (amastigota) do parasita. Estas enzimas vêm sendo descritas como fundamentais no processo de bioconversão do antimônio pentavalente para a forma trivalente. As propriedades antileishmania dos fármacos antimoniais 
provavelmente seriam decorrentes do complexo entre o $\mathrm{Sb}(\mathrm{III})$-tripanotiona e enzimas (Yan et al., 2003).

Tem sido demonstrado que as próprias enzimas antioxidantes do hospedeiro, como a glutationa, principal tiol encontrado no citosol de células de mamíferos, também contribuem no processo de bioconversão do antimônio, porém de forma menos intensa quando comparada com as enzimas da Leishmania sp. A reação entre o $\mathrm{Sb}(\mathrm{V})$ e a glutationa é favorecida em um ambiente ácido ( $\mathrm{pH} 5)$ e em temperatura elevada $\left(37{ }^{\circ} \mathrm{C}\right)$, condições encontradas no fagolisossoma, no qual reside a Leishmania (Frézard et al., 2001).

A avaliação de tióis predominantes nos lisossomos, como cisteína e cisteínaglicina, tem sido reportados como responsáveis pela redução do $\mathrm{Sb}(\mathrm{V})$ para $\mathrm{Sb}(\mathrm{III})$ a $37^{\circ} \mathrm{C}$. Notavelmente, a taxa inicial de redução do $\mathrm{Sb}(\mathrm{V})$ foi muito maior na presença destes do que quando com glutationa. A reação ocorreu tanto em pH 5 como em pH 7, mas foi favorecida em pH ácido e em elevada temperatura (Ferreira et al., 2003). Estes dados enfatizam a hipótese que o $\mathrm{Sb}(\mathrm{V})$ é reduzido in vivo pela tripanotiona no parasito Leishmania e pela cisteína ou cisteína-glicina no compartimento acídico da célula hospedeira.

Apesar dos estudos reportados na literatura, o mecanismo de ação dos antimoniais pentavalentes no tratamento das Leishmanioses ainda permanece pouco compreendido. Até o momento não está bem esclarecido se a forma ativa final dos agentes antimoniais pentavalentes é o $\mathrm{Sb}(\mathrm{V})$ ou o $\mathrm{Sb}(\mathrm{III})$ (Frézard et al., 2009). De acordo com uma segunda hipótese, o $\mathrm{Sb}(\mathrm{V})$ poderia apresentar uma atividade antileishmania intrínseca.

Demicheli e colaboradores (2002) relataram a formação de um complexo entre ribonucleosídio adenina e $\mathrm{Sb}(\mathrm{V})$. Este foi o primeiro registro de uma biomolécula relevante fisiologicamente capaz de formar complexos estáveis com $\mathrm{Sb}(\mathrm{V})$. A complexação de $\mathrm{Sb}(\mathrm{V})$ com ribonucleosídios foi encontrada ser mais rápida em $\mathrm{pH}$ ácido, indicando que é favorecida em compartimentos biológicos ácidos. Outra propriedade notável destes complexos é sua constante de dissociação muito lenta em soluções aquosas em pH neutro (Ferreira et al., 2006).

Berman e colaboradores (1985) investigaram que a síntese de proteínas, RNA e DNA foi reduzida em formas promastigotas e amastigotas de Leishmania mexicana expostas ao estibogluconato de sódio. Os autores concluíram que a diminuição da formação dos nucleosídios purina contribuiu para a redução da síntese de macromoléculas, provocando a redução da viabilidade do parasita exposto ao antimônio. Posteriormente, 
Berman e colaboradores (1987) demonstraram que o estibogluconato de sódio inibiu o catabolismo de glicose pela via glicolítica e a $\beta$-oxidação de ácidos graxos em amastigotas de Leishmania mexicana. A inibição destas vias sugeriu o mecanismo de inibição da fosforilação de ADP para ATP.

\subsubsection{Determinação da Concentração Efetiva $50 \quad \% \quad\left(\mathbf{C E}_{50}\right)$ em Macrófagos Peritoneais Infectados com Leishmania}

A atividade antileishmania do antimoniato de meglumina livre e encapsulado em diferentes formulações de lipossomas foi comparada após incubação por $120 \mathrm{~h}$. Todos os experimentos foram analisados somente quando a carga parasitária do controle revelava uma infecção de $100 \%$ após 120 h, determinada por microscopia óptica. Na TAB. 21 são apresentadas as $\mathrm{CE}_{\mathbf{5 0}}$ das diferentes formulações em macrófagos infectados com $L$. (L.) major. A formulação de AM-FTL resultou numa $\mathrm{CE}_{50}$ de 1,27 $\mu \mathrm{g} / \mathrm{mL}$ e o AM livre 11,20 $\mu \mathrm{g} / \mathrm{mL}$, estes resultados demonstraram que a formulação lipossomal foi pelo menos 10 vezes mais eficaz. AM-PS-FTL apresentou uma atividade antileishmania com $100 \%$ da morte dos parasitos com uma $\mathrm{CE}_{50}$ menor que 3,0 $\mu \mathrm{g} / \mathrm{mL}$. Com esta concentração foi possível a eliminação efetiva dos parasitos intracelulares e demonstrou ser pelo menos 10 vezes mais ativa do que o fármaco padrão. Foi verificado que as soluções de sais de $\mathrm{Sb}$ (III) e $\mathrm{Sb}(\mathrm{V})$ mostraram maior eficácia que o AM.

TABELA 21 - Avaliação da Concentração Efetiva $50 \%\left(\mathrm{CE}_{50}\right)$ de diferentes formulações lipossomais em macrófagos peritoneais infectados com amastigotas de $L$. (L.) major. IC95\%= Intervalo de Confiança 95\%; ( $\mathrm{n}=3)$.

\begin{tabular}{ccc}
\hline Amostras & $\mathbf{C E}_{\mathbf{5 0}}(\boldsymbol{\mu g} \mathbf{g} \mathbf{m L} ; \mathbf{I C ~ 9 5 \% )}$ & $\mathbf{r}^{\mathbf{2}}$ \\
\hline AM-FTL & $1,27(0,60-2,58)$ & 0,877 \\
AM-PS-FTL & $<3,0$ & - \\
AM & $11,20(7,88-15,95)$ & 0,897 \\
$\mathrm{Sb}(\mathrm{III})$ & $4,91(2,40-10,05)$ & 0,847 \\
$\mathrm{Sb}(\mathrm{V})$ & $7,78(4,05-14,95)$ & 0,806 \\
\hline
\end{tabular}

A observação microscópica dos macrófagos confirmou a atividade antileishmania das formulações de antimoniato de meglumina encapsulado em lipossomas em amastigotas de L. (L.) major. Na FIG. 22 A são mostrados macrófagos infectados com amastigotas de L. (L.) major sem tratamento com o fármaco (controle). A localização característica dos parasitos ao redor do núcleo foi observada durante a infecção. A FIG. 22 
C e D são lâminas características, mostrando a ausência de amastigotas nos macrófagos após o tratamento com os lipossomas AM-PS-FTL e AM-FTL (1,6 $\mu \mathrm{g} / \mathrm{mL})$, respectivamente. A ausência de amastigotas ou sua redução em número nos macrófagos comparando ao controle sugere a atividade antileishmania. $\mathrm{O}$ antimoniato de meglumina na concentração de $3,8 \mu \mathrm{g} / \mathrm{mL}$ não apresentou atividade suficiente para eliminar os parasitos (FIG. 22 B).
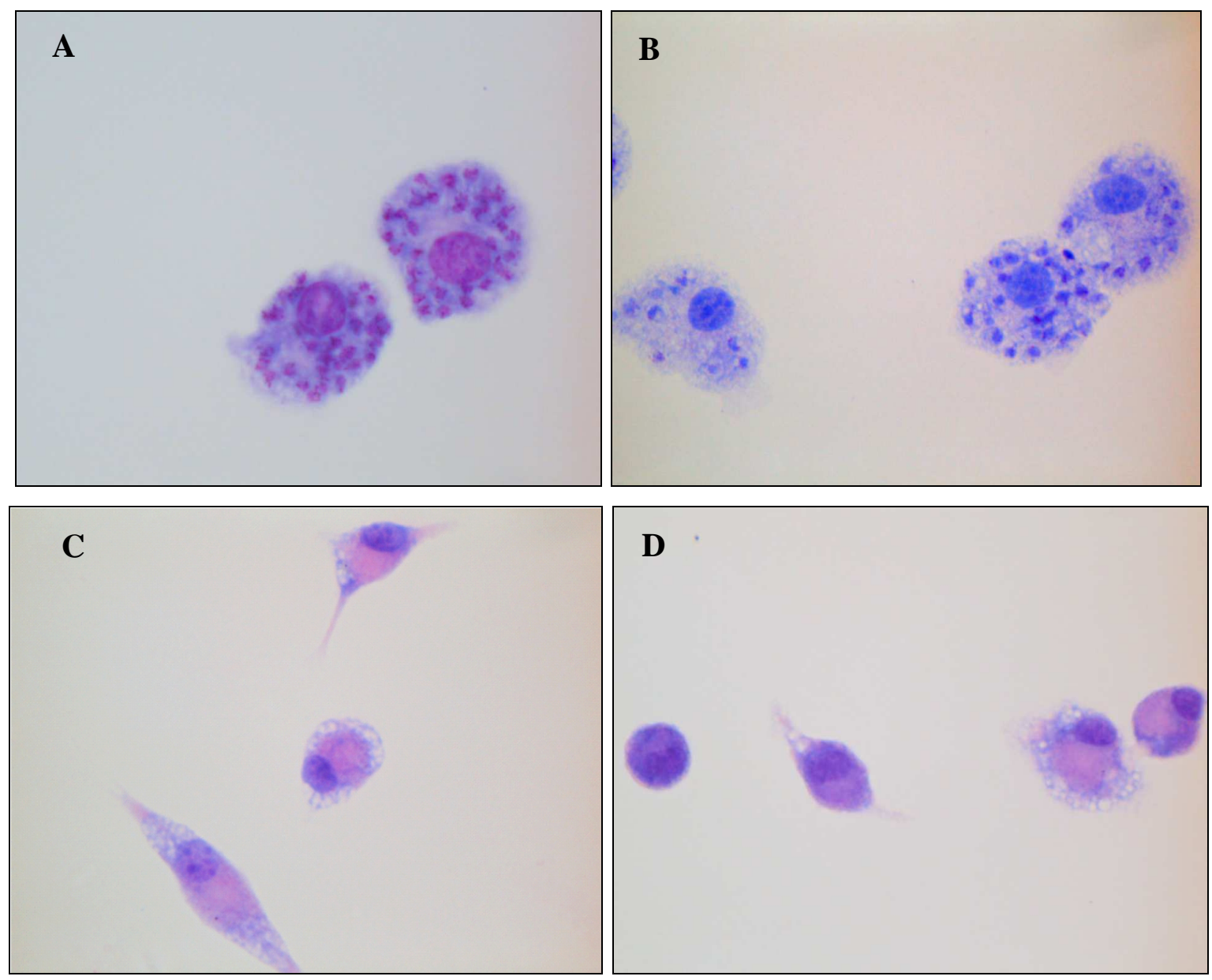

D

FIGURA 22 - Imagens microscópicas de macrófagos peritoneais infectados com amastigotas de $L$. (L.) major, observadas sob óleo de imersão (100x) num microscópio óptico. (A) controle, células não tratadas (macrófagos infectados com amastigotas); (B) macrófagos após tratamento com 3,8 $\mu \mathrm{g} / \mathrm{mL}$ de antimoniato de meglumina (macrófagos infectados com amastigotas); (C) macrófagos após tratamento com 1,6 $\mu \mathrm{g} / \mathrm{mL}$ de AMPS-FTL (macrófago livre de parasitos); (D) macrófagos após tratamento com $1,6 \mu \mathrm{g} / \mathrm{mL}$ de AM-FTL (macrófago livre de parasitos).

A determinação da $\mathrm{CE}_{50}$ dos compostos em macrófagos peritoneais infectados com amastigotas de L. (L.) chagasi é mostrada na TAB. 22. 
TABELA 22 - Avaliação da Concentração Efetiva $50 \%\left(\mathrm{CE}_{50}\right)$ de diferentes formulações lipossomais em macrófagos peritoneais infectados com amastigotas de $L$. (L.) chagasi. IC95\%= Intervalo de Confiança 95\%; (n=3).

\begin{tabular}{ccc}
\hline Amostras & $\mathbf{C E}_{\mathbf{5 0}}(\boldsymbol{\mu g} \mathbf{g} \mathbf{m L} ; \mathbf{I C}$ 95\% $)$ & $\mathbf{r}^{\mathbf{2}}$ \\
\hline AM-FDEL & $2,65(2,17-3,23)$ & 0,943 \\
AM-FEL & $0,95(0,86-1,04)$ & 0,984 \\
$\mathrm{Sb}(\mathrm{III})-\mathrm{FDEL}$ & $5,57(5,03-6,17)$ & 0,976 \\
$\mathrm{Sb}(\mathrm{V})$ & $9,04(7,47-10,93)$ & 0,936 \\
$\mathrm{Sb}(\mathrm{III})$ & $4,53(4,29-4,78)$ & 0,991 \\
AM & $60,28(56,22-64,64)$ & 0,985 \\
\hline
\end{tabular}

A avaliação in vitro da atividade antileishmania com as formulações lipossomais não apresentou boa repetibilidade, no entanto em todas as análises os lipossomas mostram-se muito mais ativos que o antimoniato de meglumina na forma livre. AM-FDEL apresentou uma $\mathrm{CE}_{50}$ de $2,65 \mu \mathrm{g} / \mathrm{mL}$ e o AM-FEL $0,95 \mu \mathrm{g} / \mathrm{mL}$, enquanto o AM mostrou uma $\mathrm{CE}_{50} 60,28 \mu \mathrm{g} / \mathrm{mL}$. Desta forma, as formulações lipossomais foram muito mais efetivas que o fármaco não encapsulado, apresentando-se aproximadamente 23 a 63 vezes mais efetivas. A comparação entre as diferentes formulações lipossomais e o antimoniato de meglumina livre mostrou significativamente maior eficácia (FIG. 23).

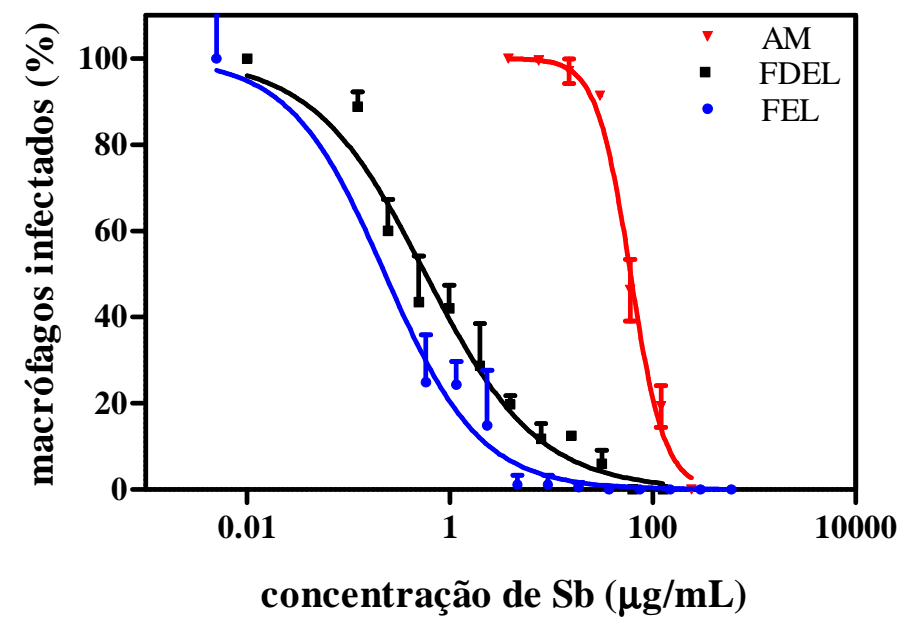

FIGURA 23 - Curva dose-resposta da determinação da Concentração Efetiva $50 \%\left(\mathrm{CE}_{50}\right)$ de diferentes formulações lipossomais em macrófagos peritoneais infectados com amastigotas de L. (L.) chagasi.

O antimônio pentavalente inorgânico mostrou-se aproximadamente 7 vezes mais ativo que o antimoniato de meglumina livre. Já antimônio trivalente inorgânico mostrou-se aproximadamente 13 vezes mais ativo, porém quando encapsulado em 
lipossoma (Sb(III)-FDEL) não mostrou diferença significativa de atividade antileishmania. Todas as preparações eliminaram completamente a carga parasitária nos macrófagos.

Os resultados encontrados neste estudo corroboram com os dados reportados por Tempone e colaboradores (2004). Os autores verificaram que o antimoniato de meglumina encapsulado em lipossomas foi significativamente mais eficaz no tratamento de macrófagos infectados com L. (L.) chagasi em comparação com o fármaco livre, mostrando uma $\mathrm{CE}_{50}$ de $27 \mu \mathrm{g} / \mathrm{mL}$ (IC $95 \%=24,6-30,4$ ) e $1,7 \mu \mathrm{g} / \mathrm{mL}$ (IC 95\% = 0,95 $3,04)$ para o antimoniato de meglumina livre e lipossomal, respectivamente. A formulação lipossomal foi 16 vezes mais eficaz que a fármaco livre.

Jaafari e colaboradores (2009) avaliaram o efeito antileishmania do sulfato de paramomicina livre e lipossomal em macrófagos infectados com $L$. (L.) major, as $\mathrm{CE}_{50}$ das formulações foram $206 \pm 10$ e $65 \pm 7 \mu \mathrm{g} / \mathrm{mL}$, respectivamente. Os autores mostram que a formulação lipossomal foi de 3 a 4 vezes mais efetiva que a forma livre. Os sistemas transportadores de fármacos apresentam-se como uma excelente ferramenta para o direcionamento seletivo de fármacos ao local alvo.

Neste trabalho foi demonstrado que as promastigotas de Leishmania não apresentam suscetibilidade ao antimônio livre ou encapsulado em lipossomas. Por outro lado, as amastigotas de Leishmania foram pelo menos dezenas de vezes mais suscetíveis ao antimônio livre e encapsulado em diferentes formulações lipossomais. Para ser ativo contra Leishmania, o $\mathrm{Sb}(\mathrm{V})$ tem que entrar na célula hospedeira, atravessar a membrana do fagolisossoma e agir contra amastigota intracelular. $\mathrm{O} \mathrm{Sb}(\mathrm{V})$ necessita sofrer uma conversão biológica para forma trivalente para desenvolver atividade antileishmania, levando assim a definição de que o $\mathrm{Sb}(\mathrm{V})$ age como uma pró-fármaco (Ephros et al., 1999).

Tem sido sugerido que a redução do antimônio pentavalente é mais lenta quando o antimônio está na sua forma complexada (antimoniato de meglumina) do que quando está na forma não complexada, indicando que a complexação do antimônio pentavalente tende a diminuir sua velocidade de redução (Ferreira et al., 2003). Outros estudos mostraram que a redução do antimônio pentavalente ocorre mais rapidamente em $\mathrm{pH}$ baixo, aproximadamente ao do fagolisossoma. Esta atividade não ocorre em promastigotas de Leishmania, somente na forma amastigota, devido à redução e ativação do antimônio pentavalente ser mediada por enzimas do parasito nesta fase de seu ciclo de vida. Assim, a perda da atividade redutora ou perda da ativação pode constituir um 
mecanismo pelo qual o parasito torna-se resistente às fármacos antimoniais (Denton et al., 2004).

Acredita-se que o antimoniato de meglumina possa servir como um sistema passivo de entrega do antimônio pentavalente para o sistema reticuloendotelial, no qual a espécie ativa - antimônio trivalente é gerada in situ (Sereno et al., 1998). Sugere-se que o antimônio pentavalente pode matar o parasita por mecanismos diretos e indiretos, e a resposta imune do hospedeiro está relacionada com a atividade do antimônio pentavalente (Ouellette et al., 2004).

\subsubsection{Determinação da Citotoxicidade}

Os efeitos citotóxicos das soluções de sais de antimônio, antimoniato de meglumina e das formulações lipossomais foram determinados. Na TAB. 23 são apresentados os resultados da citotoxicidade. As formulações de antimoniato de meglumina encapsulado em lipossomas mostraram ser cerca de 2-3 vezes mais tóxicas para células RAW que fármaco não encapsulado. AM-PS-FTL demonstrou ser ligeiramente mais tóxico que AM-FTL. As soluções de $\mathrm{Sb}(\mathrm{III})$ e $\mathrm{Sb}(\mathrm{V})$ foram cerca de 1000 e 25 vezes mais tóxicas que o antimoniato de meglumina, respectivamente. Por último, as soluções de $\mathrm{Sb}$ (III) livre e encapsulada em lipossomas não apresentaram diferenças significativas na resposta de citotoxicidade. Em macrófagos peritoneais a toxicidade do AM mostrou ser menor, $\mathrm{CE}_{50}$ maior que $20 \mathrm{mg} / \mathrm{mL}$, contudo as formulações AM-FEL e AM-FDEL não apresentaram diferença significante em sua atividade citotóxica.

TABELA 23 - Avaliação da citotoxicidade de diferentes formulações lipossomais em macrófagos peritoneais e células RAW 264.7. IC95\%= Intervalo de Confiança 95\%; n.d. = não determinado; $(\mathrm{n}=3)$.

\begin{tabular}{|c|c|c|}
\hline \multirow{2}{*}{ Amostras } & \multicolumn{2}{|c|}{$\mathrm{CE}_{50}(\mu \mathrm{g} / \mathrm{mL} ; \mathrm{IC} 95 \%)$} \\
\hline & RAW 264.7 & MØ peritoneal \\
\hline AM-FTL & $1120(950-1310)$ & n.d. \\
\hline AM-PS-FTL & $710(600-850)$ & n.d. \\
\hline AM-FEL & n.d. & 1467 (1270-1695) \\
\hline AM-FDEL & n.d. & $1012(216-4736)$ \\
\hline $\mathrm{Sb}(\mathrm{III})-\mathrm{FTL}$ & $1,5(1,3-1,8)$ & n.d. \\
\hline $\mathrm{Sb}(\mathrm{III})-\mathrm{FDEL}$ & n.d. & $3,0(2,4-3,8)$ \\
\hline AM & $1980(1820-2170)$ & $>20000$ \\
\hline $\mathrm{Sb}(\mathrm{III})$ & $2,2(2,0-2,4)$ & $2,7(2,3-3,0)$ \\
\hline $\mathrm{Sb}(\mathrm{V})$ & $79,8(72,6-85,9)$ & $19,8(18,0-21,7)$ \\
\hline
\end{tabular}


Nenhuma das formulações lipossomais livres de fármaco (controle), nas concentrações avaliadas, apresentaram toxicidade as células macrofágicas, confirmado pela análise morfológica normal em microscopia óptica.

Os resultados observados neste estudo corroboram com os dados reportados anteriormente. Os antimoniais pentavalentes são 10 vezes menos tóxicos para células de mamíferos que os antimoniais trivalentes. Do mesmo modo, os fármacos contendo antimoniais pentavalentes são menos tóxicas para o homem e apresentam um alto índice terapêutico que as preparações orgânicas de antimônio trivalente (Roberts et al., 1995).

A relação entre a toxicidade em células de mamífero e a atividade antileishmania, dada pelo Índice de Seletividade (SI) é mostrada na TAB. 24. Esta avaliação resultou em um valor consideravelmente alto de 882 para o AM-FTL. Já para a formulação composta por fosfatidilserina, este valor é provavelmente superior a 257. As formulações AM-FDEL e AM-FEL apresentaram índice de 1544 e 382, respectivamente. Considerando que o valor para o antimoniato de meglumina livre é 177, todas as formulações lipossomais mostraram maior eficácia no tratamento in vitro das Leishmanioses, com redução da toxicidade, e alto índice de seletividade. $\mathrm{O} \mathrm{Sb}(\mathrm{V})$ revelou um valor baixo, enquanto que a solução de $\mathrm{Sb}(\mathrm{III})$ foi muito mais tóxica para os macrófagos (células hospedeiras) do que contra amastigotas de Leishmania sp.

TABELA 24 - Avaliação do Índice de Seletividade dos antimoniais livres e encapsulados em lipossomas.

\begin{tabular}{cc}
\hline Amostras & Índice de Seletividade \\
\hline AM-FTL & 882 \\
AM-PS-FTL & $>257$ \\
AM-FDEL & 382 \\
AM-FEL & 1544 \\
Sb(III)-FDEL & 0,54 \\
AM & 177 \\
Sb(III) & 0,45 \\
Sb(V) & 10 \\
\hline
\end{tabular}

Estes resultados enfatizam a utilidade de um sistema de transporte de fármacos como os lipossomas visando à redução da toxicidade e o aumento do índice terapêutico, uma vez que cumpre os requisitos primordiais para serem considerados sistemas eficientes na terapia. Os lipossomas também devem proteger o fármaco dos processos metabólicos que eventualmente possam degradá-lo na circulação sanguínea antes de atingir seu alvo, 
devem proteger os tecidos adjacentes de uma elevada captação do fármaco, concentrandose majoritamente no órgão ou célula a que se destina atingir e, devem aumentar a captação pelas células do tecido alvo, provocando o aumento da eficiência do fármaco em relação a formulação não lipossomal (Torchilin, 2005).

\subsubsection{Estudos de Interação Célula-Lipossoma}

\subsubsection{Captação e internalização de lipossoma marcado com corante fluorescente por macrófago RAW 264.7 não infectado e infectado com $L$. $(L$.$) major$}

Na tentativa de investigar a captação de lipossomas em macrófagos não infectados e em infectados com $L$. (L.) major, os lipossomas marcados com um corante fluorescente vermelho (Dil) foram incubados com as células e analisados por microscopia de fluorescência. Como mostrado na FIG. 24, a porcentagem de lipossomas fluorescentes em macrófagos infectados foi maior e a intensidade de fluorescência aumentou num curto período de tempo. Após 10 minutos de incubação com lipossomas, mais de $80 \%$ dos macrófagos infectados apresentaram fluorescência em torno de seus núcleos. A saturação da captação ocorreu antes de $1 \mathrm{~h}$ de incubação, onde $100 \%$ das células apresentaram fluorescência. Tais efeitos foram consideravelmente menores quando os macrófagos não infectados foram utilizados como comparação. Após 10 minutos de incubação, cerca de $30 \%$ dos macrófagos não infectados apresentaram fluorescência ao redor de seus núcleos. Em seguida da primeira hora de avaliação, pelo menos $50 \%$ das células mostraram fluorescência. Depois de $4 \mathrm{~h}$, mais de $80 \%$ das células apresentaram fluorescência, provavelmente a saturação da captação ocorreu antes de 18 h de incubação, onde $100 \%$ dos macrófagos continham fluorescência. 

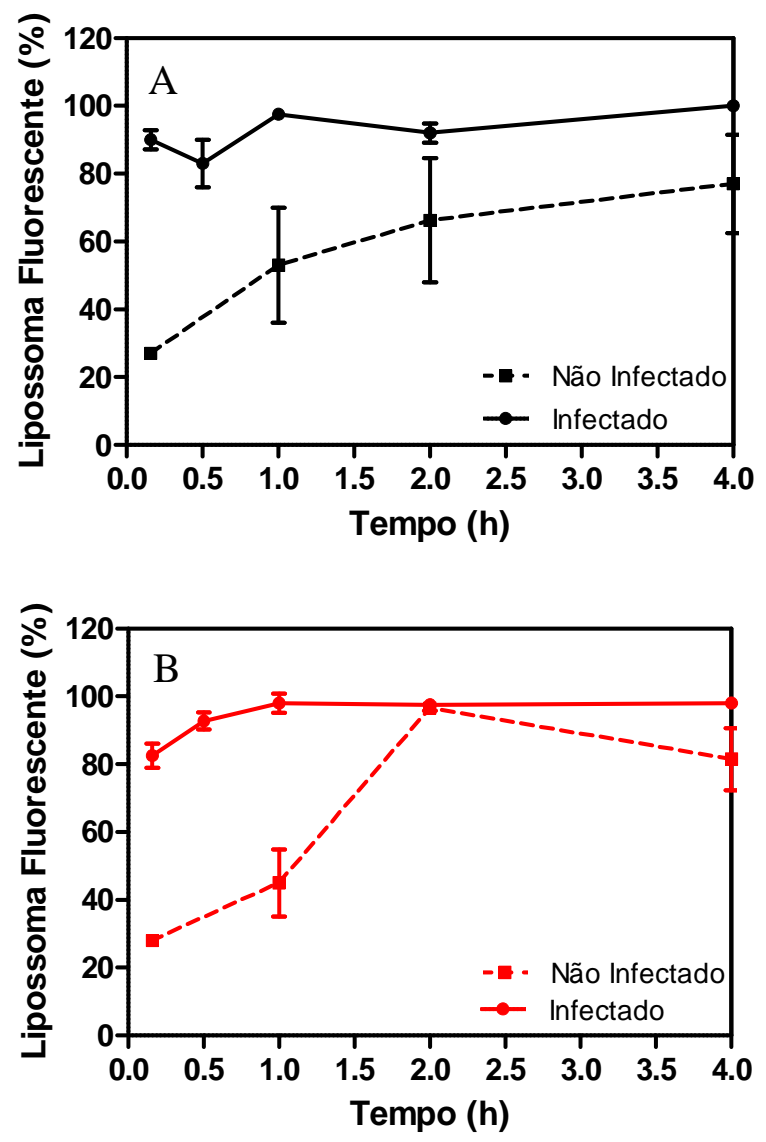

FIGURA 24 - Comparação da captação de lipossomas fluorescentes por macrófagos não infectados e infectados com $L$. (L.) major em diferentes períodos de tempo (1,83 $\mu$ mol lipídios/poço e marcados com 0,02 $\mu$ mol de Dil). A) macrófagos incubados com Dil-FTL; B) macrófagos incubados com Dil-PS-FTL. Os dados são apresentados como a média \pm desvio padrão $(n=2)$.

Na FIG. 25 é possível analisar o processo de captação dos lipossomas fluorescentes por macrófagos infectados. A absorção dos lipossomas ocorreu durante a primeira hora da avaliação. A intensidade de sinal de fluorescência foi associada com o período de tempo de incubação, resultando numa intensidade mais forte com um maior tempo. Além disso, foi verificado elevado acúmulo dos lipossomas fluorescentes nos macrófagos mesmo após 24 h de incubação. No entanto, não foram observadas diferenças significativas na captação dos lipossomas contendo antimoniato de meglumina (Dil-AMFTL), fosfatidilserina (Dil-PS-FTL) e sem fosfatidilserina (Dil-FTL) (FIG. 26). 


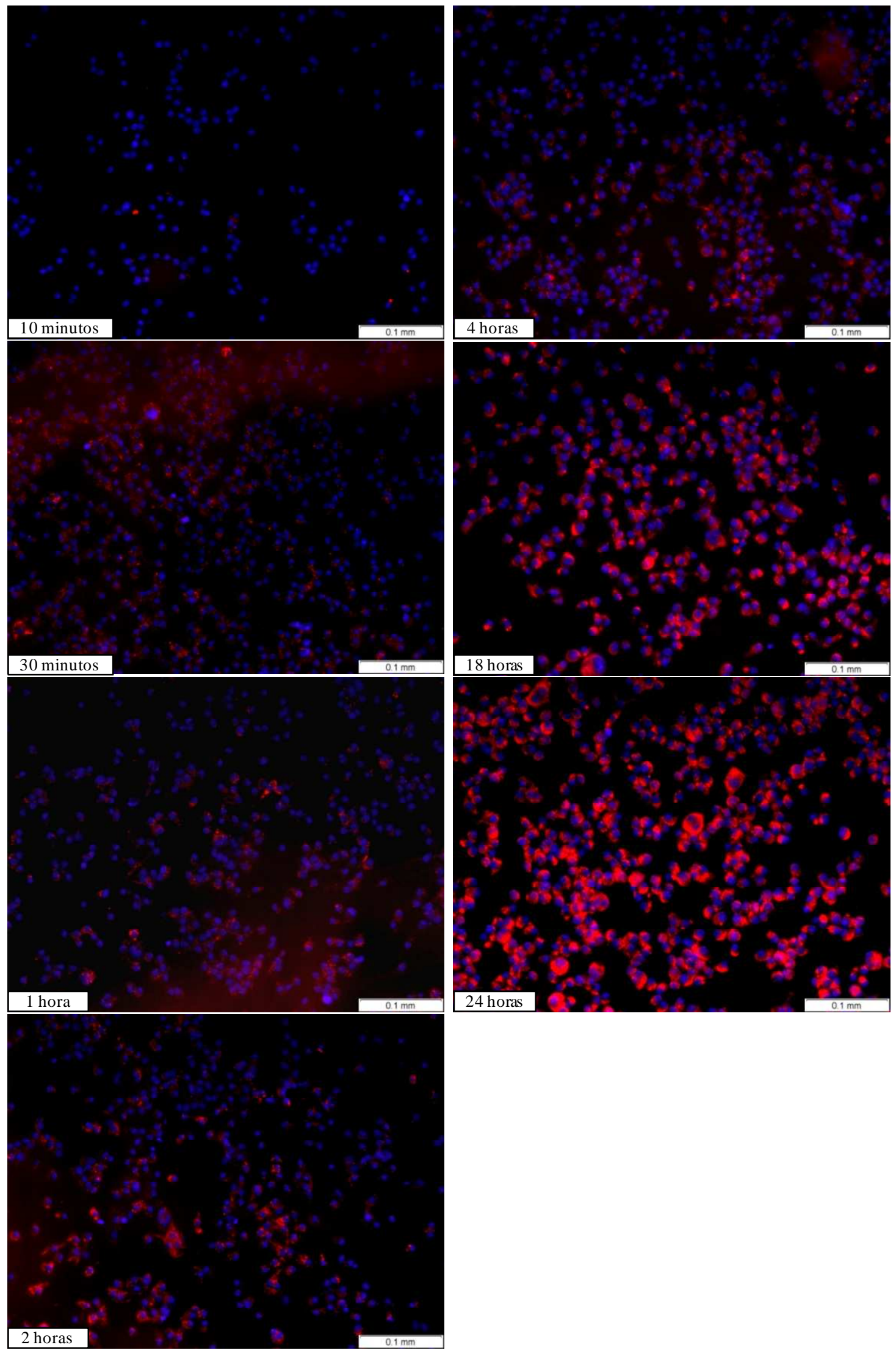

FIGURA 25 - Imagens por microscopia de fluorescência de macrófagos infectados com $L$. (L.) major. Células incubadas com lipossomas fluorescentes (vermelho). Corante DAPI adicionado como um marcador de DNA, núcleos (azul). 


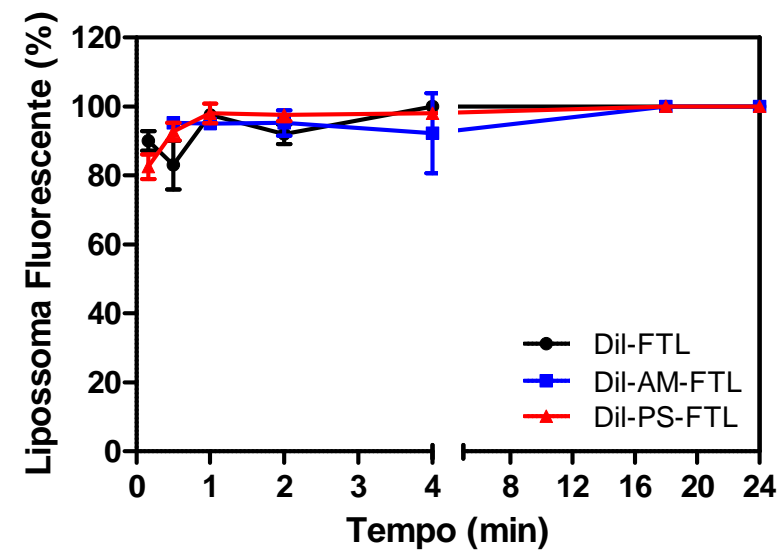

FIGURA 26 - Comparação da captação de lipossomas fluorescentes por macrófagos infectados com $L$. (L.) major em diferentes períodos de tempo $(1,83 \mu \mathrm{mol}$ lipídios/poço e marcados com $0,02 \mu$ mol de Dil). Os dados são apresentados como a média \pm desvio padrão $(n=2)$.

Na FIG. 27 é possível verificar a localização dos lipossomas fluorescentes, predominantemente armazenados dentro das células na região perinuclear, o padrão de fluorescência aparece como uma população heterogênea de manchas vermelhas dentro da membrana celular, presumivelmente no citoplasma. A carga parasitária foi determinada por microscopia óptica revelando uma infecção de $41 \%$ após 24 h. O resultado também foi confirmado por microscopia de fluorescência (FIG. 28). Porém, pela metodologia utilizada neste estudo, não foi possível inferir a delimitação das células e suas organelas, como membrana celular e fagolisossoma. 

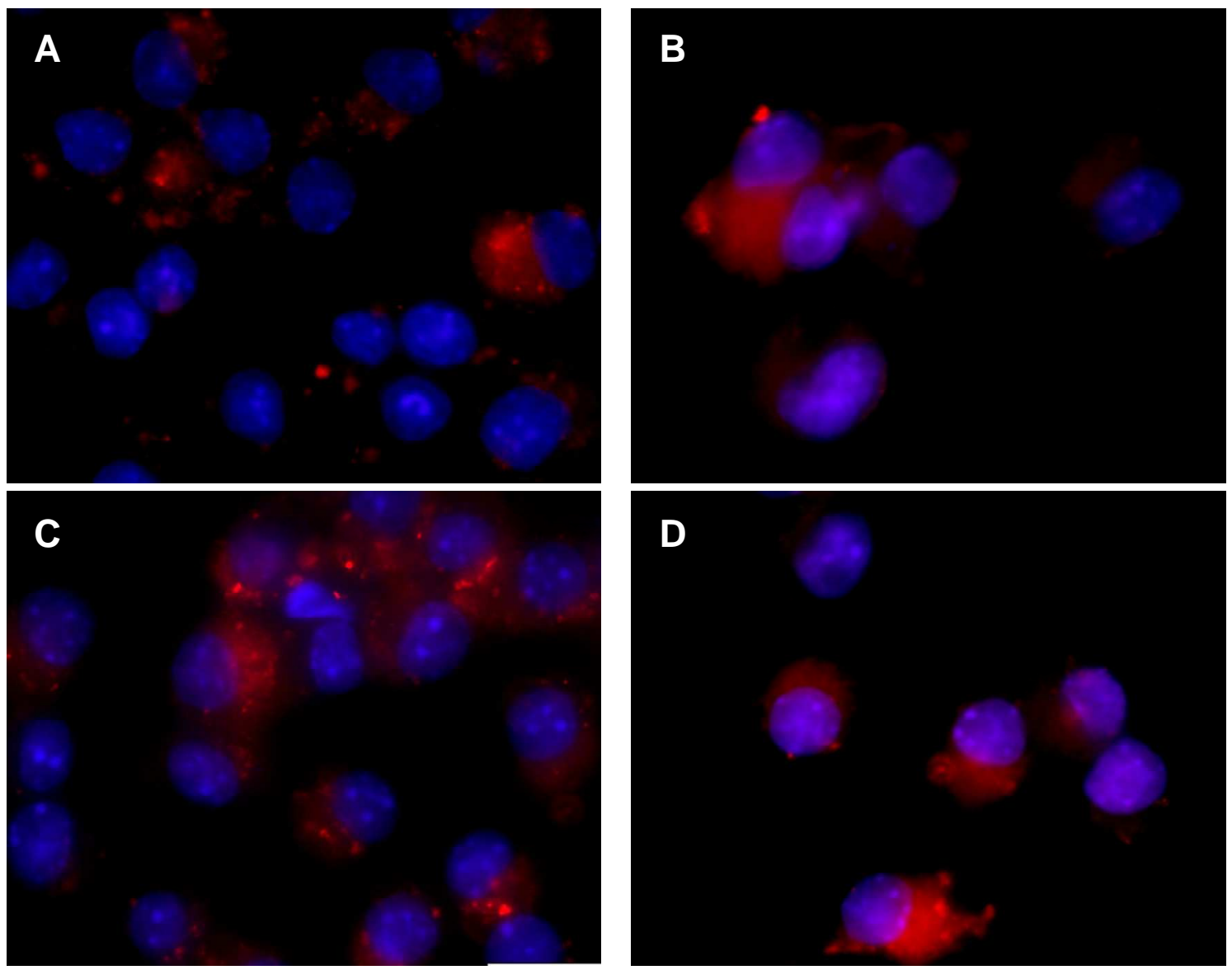

FIGURA 27 - Imagens por microscopia de fluorescência de macrófagos não infectados e infectados com $L$. (L.) major. As células foram incubadas com lipossomas fluorescentes (vermelho) durante $1 \mathrm{~h}(1,83 \mu \mathrm{mol}$ lipídios/poço e marcados com 0,02 $\mu$ mol de Dil). O corante DAPI foi adicionado como um marcador de DNA, núcleos (azul). A) macrófagos infectados e incubados com DilFTL; B) macrófagos não infectados e incubados com Dil-FTL; C) macrófagos infectados e incubados com Dil-PS-FTL; D) macrófagos não infectados e incubados com Dil-PS-FTL (60X). 


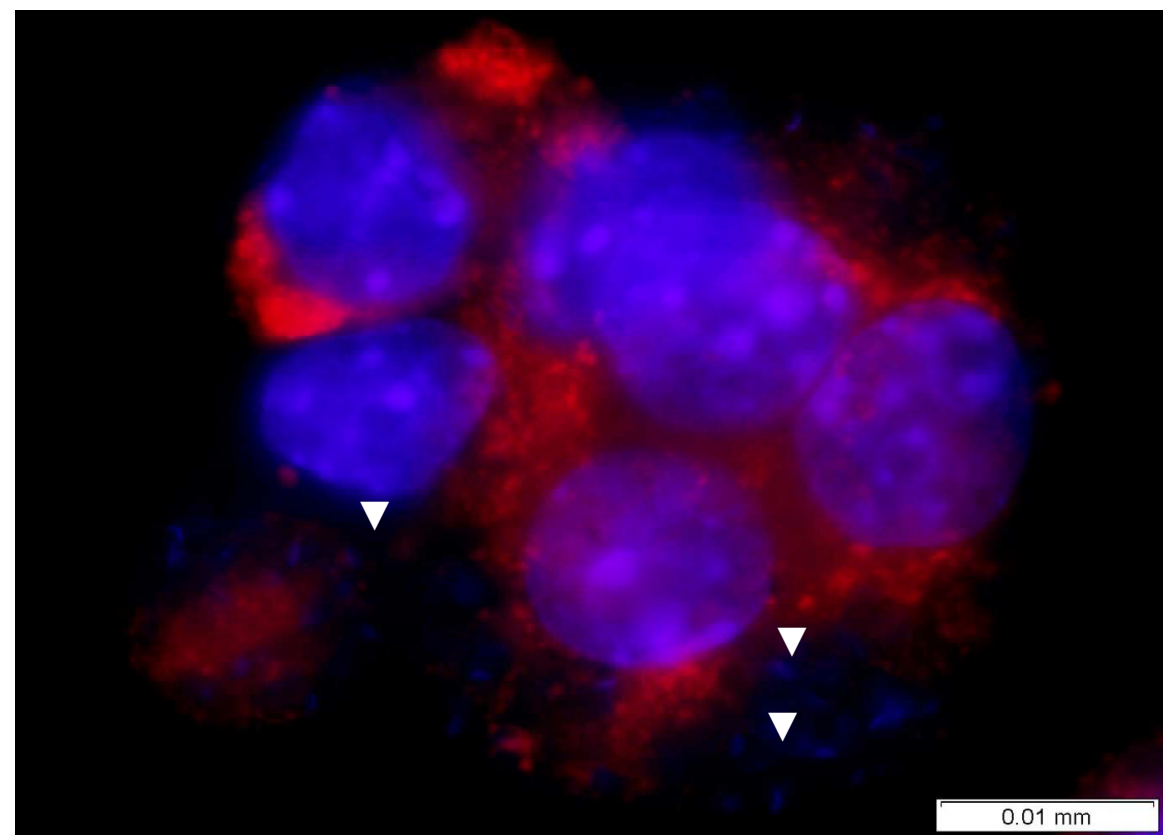

FIGURA 28 - Imagens por microscopia de fluorescência de macrófagos infectados com $L$. (L.) major. As células foram incubadas com lipossomas fluorescentes (vermelho) durante $18 \mathrm{~h}(1,83 \mu \mathrm{mol}$ lipídios/poço e marcados com 0,02 $\mu$ mol de Dil). O corante DAPI foi adicionado como um marcador de DNA, núcleos (azul). (100x). As setas brancas indicam as áreas com alta concentração de amastigotas.

Neste estudo foi observado que a captação e internalização de lipossomas por macrófagos mostraram ser um processo rápido relacionado a diferentes mecanismos. Tem sido verificado o envolvimento de receptores "scavenger" na associação e internalização de lipossomas contendo fosfatidilserina em macrófagos (Rothkoph et al., 2005). O acúmulo de lipossomas nos macrófagos sugere que o processo de hidrólise lisossomal faz parte do metabolismo dos lipossomas. Além disso, foi analisado que o sistema de microfilamentos dos macrófagos é necessário para a internalização dos lipossomas (Tempone et al., 2004).

Os resultados demonstraram que os lipossomas são capazes de direcionar a fármaco aos macrófagos e entregá-la próximo aos fagolisossomas. Tempone e colaboradores (2004) sugeriram que os lipossomas contendo fosfatidilserina podem ser direcionados aos fagolisossomas de macrófagos infectados com L. (L.) chagasi por interação com anexinas, proteínas hidrofílicas que se ligam aos lipossomas com carga negativa e agem como molécula de conexão no processo de fusão de vesículas. Dentro deste compartimento, os lipossomas possivelmente são rompidos por foslipases de fase ácida, sofrendo degradação fagolisossomal e liberando seu conteúdo (Ahsan et al., 2002). 
Pela análise por microscopia de fluorescência não foram observadas diferenças significativas entre a captação de lipossomas com carga neutra e negativa. Contudo acredita-se que o processo de fagocitose por macrófagos é favorecido em lipossomas com carga, devido a uma interação eletrostática específica ou não entre as células e as vesículas. A inclusão de fosfolipídios negativamente carregados, tais como fosfatidilserina (PS) e fosfatidilglicerol (PG) em vesículas multilamelares constituídas com fosfatidilcolina (PC) aumentou a ligação e fagocitose por macrófagos, por outro lado vesículas neutras, compostas exclusivamente de PC não foram eficientemente capturadas por macrófagos. De fato, a inclusão da PS pode conduzir ao reconhecimento destes lipossomas por células do SMF (Fidler, 1988; Schroit et al., 1986). Gilbreath e colaboradores (1985; 1986) observaram que somente lipossomas contendo fosfatidilserina foram capazes de inibir a atividade microbicida de macrófagos induzidos por linfocinas contra L. major, por interferência seletiva e reversível no mecanismo de ativação macrofágica, mediada pela fosfatidilserina.

Tem sido sugerido o envolvimento de receptores de macrófagos na captação e internalização dos agentes antimoniais. Roberts e colaboradores (1995) analisaram soluções de antimônio livres e complexadas com manan, um polissacarídeo reconhecido por receptores de manose, incubadas com macrófagos. Os autores verificaram que os macrófagos acumularam antimônio durante as 4 horas de exposição, o qual ficou retido intracelularmente por pelo menos 3 dias. Eles concluíram que os macrófagos servem como reservatório para os agentes antimoniais, prolongando a exposição do parasito à fármaco.

Os resultados obtidos por microscopia de fluorescência mostraram um aumento na captação de lipossomas fluorescentes em macrófagos infectados durante um tempo curto e inicial de incubação em comparação com macrófagos não infectados. A infecção pode ter modificado sua atividade metabólica e sua capacidade de ingestão de material particulado, alterando a circulação intracelular dos lipossomas. Outro resultado bastante relevante foi a observação dos lipossomas nas células por mais de 24 horas, demonstrando alta disponibilidade do fármaco na célula hospedeira, fator essencial para que a atividade antileishmania seja atingida. A rápida captação de lipossomas por macrófagos infectados também foi observada por Heath e colaboradores (1984), onde concluíram que os lipossomas liberam seu conteúdo próximo ao parasito por um processo de fusão com o fagolisossoma. 


\subsubsection{Associação e ligação de lipossoma marcado com corante fluorescente por macrófago RAW 264.7 não infectado e infectado com $L$. (L.) major usando citometria de fluxo (FACS)}

Para analisar quantitativamente a interação dos lipossomas com macrófagos não infectados e infectados com $L$. (L.) major, os lipossomas fluorescentes (Dil-FTL) foram incubados com as células e a fluorescência foi determinada por citometria de fluxo como mostrado na FIG. 29.
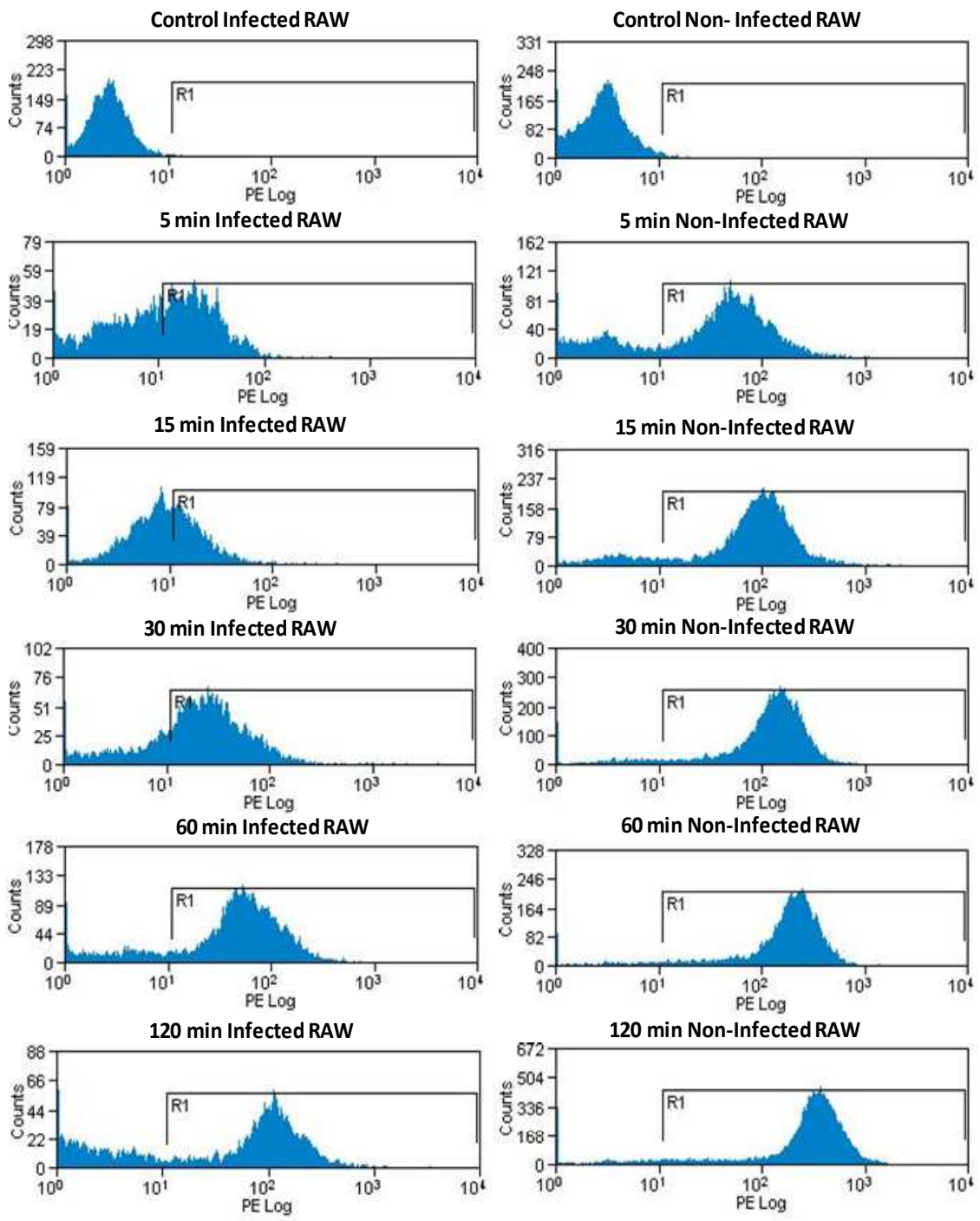

FIGURA 29 - Comparação da associação e ligação de lipossomas fluorescentes com macrófagos não infectados e infectados com L. (L.) major. As células foram incubadas com Dil-FTL $(9,5 \mu \mathrm{mol}$ lipídios/poço e marcados com $0,1 \mu \mathrm{mol}$ de Dil) e analisadas pela contagem e medição das características fluorescentes de 10.000 células únicas em suspensão usando FACS. 
A intensidade de sinal de FACS do Dil-FTL em macrófagos não infectados foi elevada em comparação com os macrófagos infectados (FIG. 30). Além disso, revelaram alta taxa de associação com os lipossomas fluorescentes durante todo o tempo de observação (TAB. 25). Trinta minutos após a incubação com Dil-FTL mais de $90 \%$ dos macrófagos não infectados apresentaram fluorescência. Conforme verificado em ambos os macrófagos, a intensidade de sinal de fluorescência e associação estava diretamente relacionada com o tempo de incubação. Após 60 minutos de incubação, foi observada uma diminuição de associação nos macrófagos infectados, no entanto em células não infectadas a redução da associação ocorreu logo após 30 minutos de incubação.

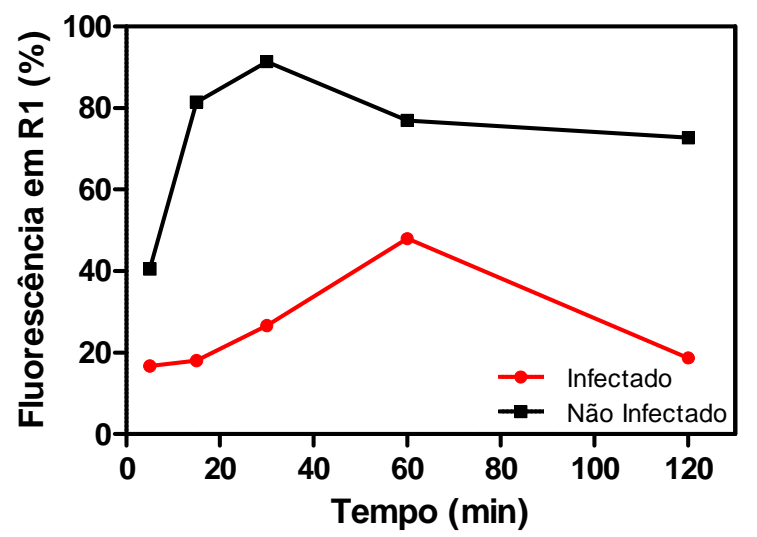

FIGURA 30 - Comparação da associação e ligação de lipossomas fluorescentes com macrófagos não infectados e infectados com $L$. (L.) major. Células foram incubadas com Dil-FTL $(9,5 \mu \mathrm{mol}$ lipídios/poço e marcados com 0,1 $\mu \mathrm{mol}$ de Dil) e analisadas pela contagem e medição das características fluorescentes de 10.000 células únicas em suspensão usando FACS. Porcentagens de fluorescência em R1.

TABELA 25 - Comparação da associação e ligação de lipossomas fluorescentes com macrófagos não infectados e infectados com $L$. (L.) major. Células incubadas com Dil-FTL $(9,5 \mu \mathrm{mol}$ lipídios/poço e marcados com $0,1 \mu \mathrm{mol}$ de Dil) e analisadas pela contagem e medição das características fluorescentes de 10.000 células únicas em suspensão usando FACS.

\begin{tabular}{ccc}
\hline \multirow{2}{*}{ Amostras } & \multicolumn{2}{c}{ R1 (\%) } \\
\cline { 2 - 3 } & MØ Infectado & MØ Não Infectado \\
\hline Controle & 0,13 & 0,53 \\
$5 \mathrm{~min}$ & 16,71 & 40,58 \\
$15 \mathrm{~min}$ & 18,03 & 81,48 \\
$30 \mathrm{~min}$ & 26,66 & 91,36 \\
$60 \mathrm{~min}$ & 47,92 & 76,92 \\
$120 \mathrm{~min}$ & 18,67 & 72,69 \\
\hline
\end{tabular}


Os resultados obtidos neste estudo sugerem que a associação e ligação dos lipossomas foram mais intensas nos macrófagos não infectados corroborando com os dados observados através de microscopia de fluorescência, onde foi mostrado que os macrófagos não infectados apresentaram baixa internalização dos lipossomas nos primeiros tempos avaliados. Enquanto que os macrófagos infectados apresentaram relativamente baixa associação com os lipossomas, uma vez que o processo de internalização mostrou ser bem rápido, como observado pela microscopia.

Pela análise da FIG. 30 é possível propor que inicialmente ocorre a associação e ligação dos lipossomas à superfície celular, representada pelo aumento da intensidade de sinal de fluorescência. $\mathrm{O}$ pico deste processo em macrófagos não infectados foi atingido mais rápido do que em macrófagos infectados, 30 e 60 minutos, respectivamente. Após esse período foi verificado um decréscimo da intensidade de sinal de fluorescência, representando o processo de internalização dos lipossomas pelas células. Estes dados representam o processo de interação celular do lipossoma. Uma vez que em contato com a célula alvo, o lipossoma necessita primeiramente se ligar e se associar à superfície celular, para posteriormente ser internalizado e degradado para a liberação do fármaco.

A complexa interação dos lipossomas com as células fagocíticas é descrita em diversas etapas que incluem adsorção estável à superfície da célula, captação celular das vesículas intactas por um mecanismo dependente de energia e degradação lisossomal dos lipossomas e seu conteúdo. Adsorção do lipossoma à superfície da célula parece ser a etapa limitante, desde que se possa considerar que vesículas adsorvidas estavelmente são mais suscetíveis a subsequiente captação que as vesículas que estão fracamente associadas com a superfície da célula. Vários pré-requisitos devem ser cumpridos para que os lipossomas entreguem com êxito os agentes biologicamente ativos aos macrófagos: os lipossomas devem prontamente se ligar e ser fagocitado por fagócitos livres e fixos; devem prevenir a degradação do fármaco encapsulada; devem conservar o agente encapsulado para entregar ao compartimento intracelular das células fagocíticas e devem-se localizar em macrófagos nos órgãos onde ocorrem infecções, metástases ou distúrbios associados aos macrófagos (Fidler, 1988).

Weldon e colaboradores (1983) observaram em macrófagos infectados por $L$. donovani a possível via pelo qual os lipossomas entram em contato direto com o parasito. Primeiro, o lipossoma entra na célula via fagocitose. Segundo, o fagossoma funde com o lisossoma. Terceiro, o lisossoma (contendo o lipossoma) funde com o vacúolo parasitóforo (fagolisossoma) e expõe o lipossoma ao parasito. Quarto, o lipossoma libera a fármaco 
encapsulada diretamente adjacente ao parasito, ou, quinto, o lipossoma é capturado pelo próprio parasito, por endocitose.

Células macrofágicas em cultura celular, como RAW 264.7 são amplamente utilizadas para estudar as propriedades fagocíticas de macrófagos e os efeitos de fármacos na função do macrófago. Elas compartilham quase toda homologia funcional significativa com os macrófagos peritoneais murinos (Nan et al., 2004). Este modelo demonstrou ser muito útil para estudar os mecanismos de associação, ligação, captação e internalização dos lipossomas marcados com fluorescência. Cabe ressaltar que pela análise por microscopia de fluorescência foi possível a visualização estrutural dos macrófagos com a definição apenas do núcleo celular e, a localização dos lipossomas ao seu redor, o que permitiu quantificar o processo de internalização e determinar o perfil de distribuição celular dos lipossomas. Pela análise por citometria de fluxo foi possível caracterizar o processo de associação e ligação dos lipossomas aos macrófagos. Mais estudos são necessários para distinguir os mecanismos exatos da interação célula-lipossoma, tais como, utilizar marcadores de organelas e processos celulares em ambas as avaliações (Schroit et al., 1986).

\subsubsection{Estudos de biodistribuição do antimônio lipossomal (FDEL-AMI)}

A utilização de radioisótopos como marcadores de moléculas envolvidas na estrutura biológica é uma ferramenta que permitiu estudar a biodistribuição de lipossomas in vivo e determinar sua farmacocinética. $\mathrm{O}$ antimoniato de meglumina irradiado encapsulado em lipossomas (FDEL-AMI) e o antimoniato de meglumina irradiado na forma livre (AMI) foram avaliados em camundongos sadios, após a administração intraperitoneal.

Nos estudos de biodistribuição foi observado que no cérebro o pico de absorção foi alcançado nos 15 minutos após a administração do AMI, seguido da eliminação, onde os níveis de antimônio mantiveram-se abaixo de 0,03\%. Porém, nos animais que receberam FDEL-AMI, o cérebro apresentou maior concentração de dose e sustentou por tempo prolongado (FIG. 31 A). O coração mostrou níveis semelhantes de dose nos tempos iniciais. Entretanto, após 24 horas, foi verificado que o FDEL-AMI mostrou comparativamente elevada dose, mas seguido de 48 horas houve severa redução, atingindo níveis de $0,03 \%$ da dose (FIG. 31 B). 

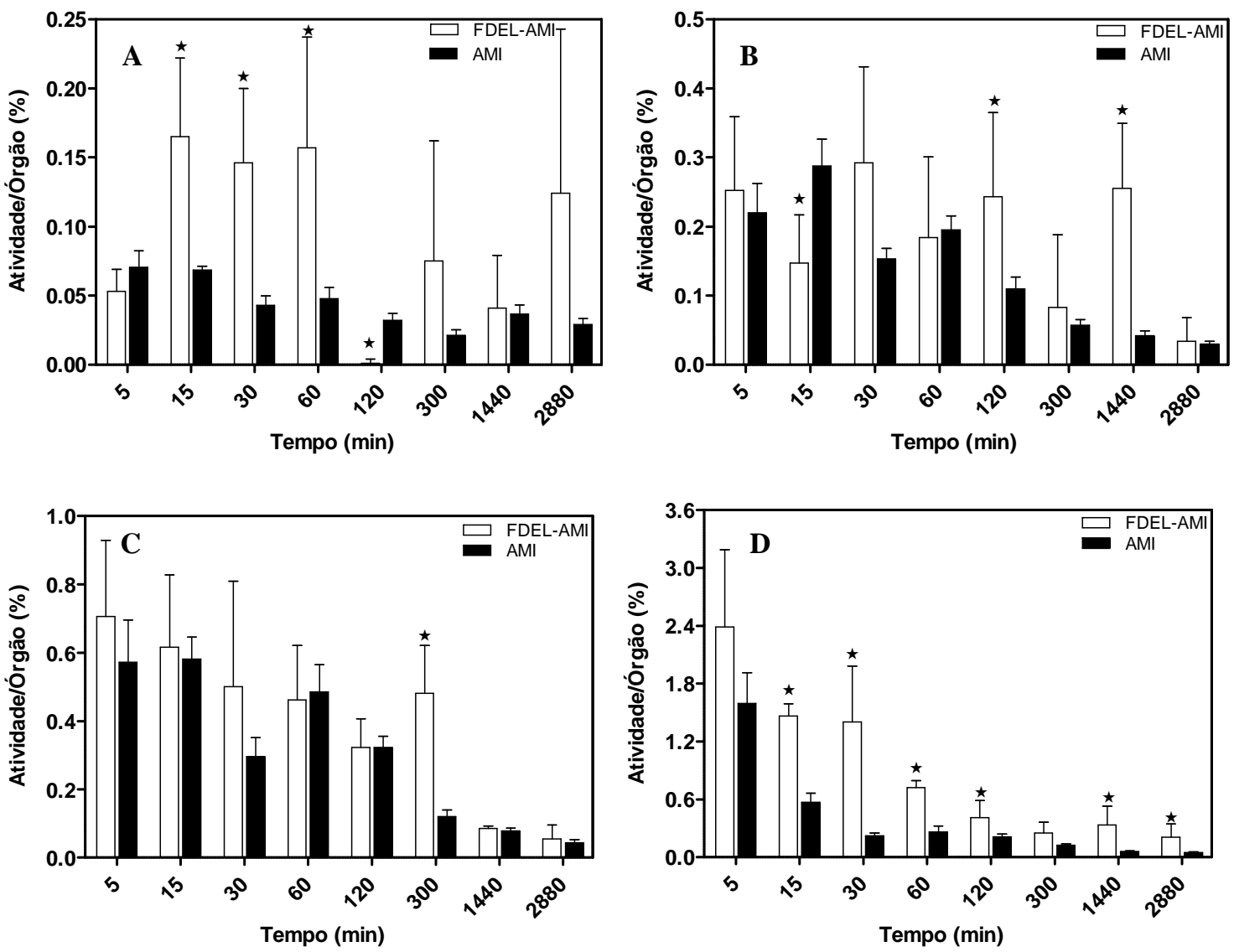

FIGURA 31 - Biodistribuição do antimônio em camundongos sadios, após a injeção intraperitoneal das formulações de antimoniato de meglumina irradiado encapsulado em lipossomas (FDEL-AMI) e antimoniato de meglumina irradiado livre (AMI). (A) cérebro; (B) coração; (C) pulmão; (D) útero/ovários. Os dados são indicados como média \pm desvio padrão $(\mathrm{n}=$ $5) . \star=$ diferença estatisticamente significante entre as formulações $(\mathrm{P}<0,05)$.

No pulmão o pico da absorção de ambas as formulações ocorreu entre os 15 minutos iniciais da administração, acompanhado do clareamento progressivo da dose, atingindo níveis de $0,05 \%$, após 48 h (FIG. 31 C). No útero e ovário o pico da concentração da dose ocorreu nos 5 minutos iniciais da administração e, passados 30 minutos, houve redução para menos da metade da dose, que seguiu com eliminação contínua, mas nos animais que receberam FDEL-AMI houve maior concentração de dose (FIG. 31 D).

Apesar da diferença significativa entre a captação tecidual do antimônio lipossomal e livre, estes resultados constataram que não houve níveis expressivos de captação e acúmulo de ambas as formulações avaliadas em órgãos como útero e ovário e órgãos vitais, tais como: coração, pulmão e cérebro. Assim, pode-se sugerir que o 
antimoniato de meglumina livre ou lipossomal não apresentaram propriedades tóxicas para estes órgãos, onde o mesmo foi mostrado por Paumgartten e colaboradores (2001), quando administraram doses elevadas de antimoniato de meglumina em ratas grávidas, e mesmo assim não verificaram toxicidade materna.

Foi verificado na musculatura esquelética total significativamente maior captação do antimoniato de meglumina livre do que lipossomal durante todos os tempos avaliados. Após 15 minutos de sua administração ocorreu a distribuição e progressiva eliminação, atingindo níveis de aproximadamente $1 \%$ da dose, 48 horas após a injeção do fármaco (FIG. 32). Estes resultados podem ser explicados pelo fato da musculatura estriada esquelética corresponder a $40 \%$ do peso corpóreo do animal e, os lipossomas não apresentarem afinidade a este tecido.

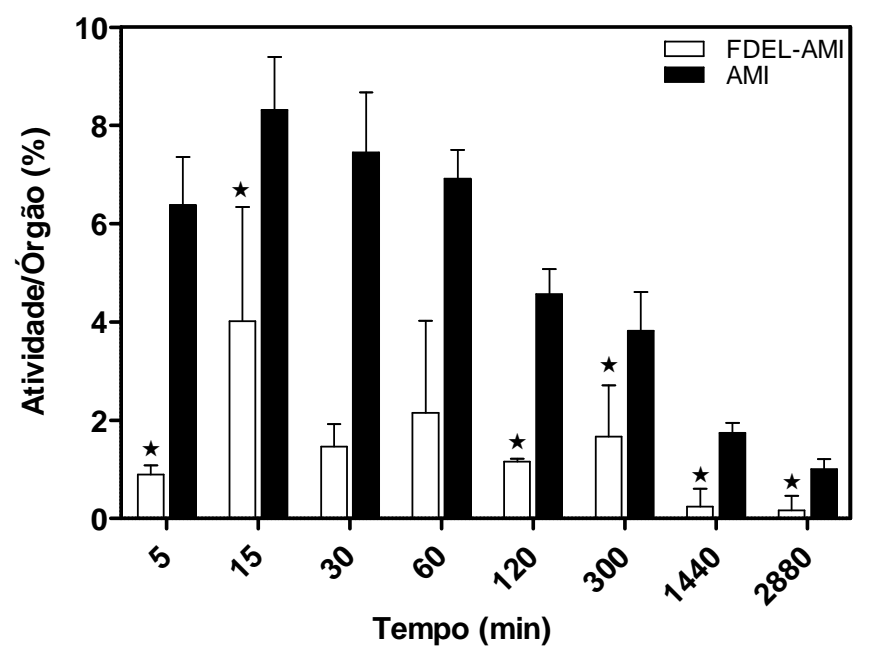

FIGURA 32 - Biodistribuição do antimônio na musculatura esquelética de camundongos sadios, após a injeção intraperitoneal das formulações de antimoniato de meglumina irradiado encapsulado em lipossomas (FDEL-AMI) e antimoniato de meglumina irradiado livre (AMI). Os dados são indicados como média \pm desvio padrão $(n=5)$. $\star=$ diferença estatisticamente significante entre as formulações $(\mathrm{P}<0,05)$.

Nos estudos de biodistribuição do antimoniato de meglumina livre foi observado que os níveis mais altos de antimônio no baço foram alcançados rapidamente, nos 5 minutos após a administração do fármaco, correspondendo a aproximadamente 1,7 \% da dose. Durante as 48 horas da administração, ocorreu degradação contínua e lenta, alcançando níveis de $0,1 \%$ da dose administrada (FIG. 33). Para o antimoniato de meglumina lipossomal, o nível mais alto de fármaco foi verificado 5 h depois da injeção, 
correspondendo a $6 \%$ da dose, sendo aproximadamente 40 vezes superior aos níveis apresentados pelo AMI. Mais importante ainda, os níveis de dose foram significativamente maiores durante todo o tempo avaliado e mantidos por mais de 48 horas, onde foi observado cerca de 20 vezes mais elevado.
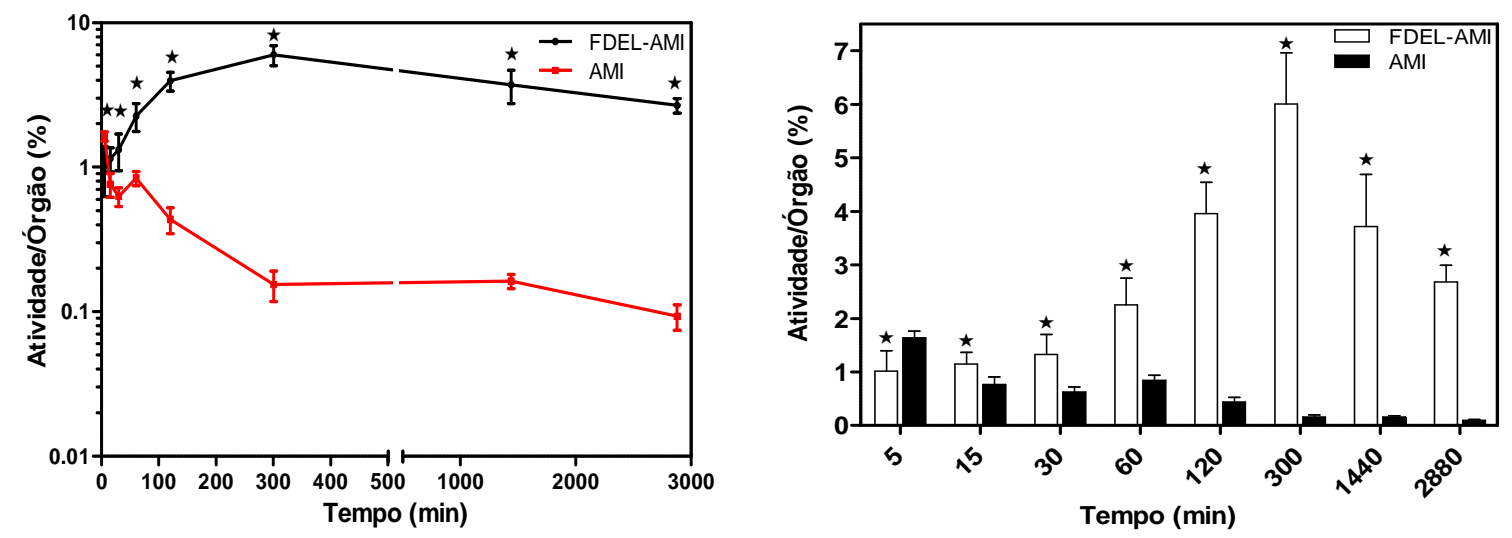

FIGURA 33 - Biodistribuição do antimônio no baço de camundongos sadios, após a injeção intraperitoneal das formulações de antimoniato de meglumina irradiado encapsulado em lipossomas (FDEL-AMI) e antimoniato de meglumina irradiado livre (AMI). Os dados são indicados como média \pm desvio padrão $(\mathrm{n}=5)$. $\star=$ diferença estatisticamente significante entre as formulações $(\mathrm{P}<0,05)$.

Estes resultados ressaltam a utilidade dos lipossomas no tratamento das leishmanioses, uma vez que, após o tratamento com antimoniato de meglumina não foram observados altos níveis de antimônio tecidual no baço, sendo a fármaco administrada incapaz de provocar a supressão do parasito, este fato pode ser explicado possivelmente pela baixa taxa de perfusão sanguínea no órgão (Carter et al., 1988). Acredita-se que a presença de altos níveis de antimônio no baço seja necessária para a cura da infecção, porém não é uma condição suficiente e única para a supressão do parasito (Gellhorn \& Van Dyke, 1946). Assim, são necessários estudos para identificação dos locais de maior concentração do fármaco e determinação dos locais de alta infecção para evitar falhas e relapsos no tratamento.

A captação do antimoniato de meglumina livre pelo fígado (FIG. 34) aumentou progressivamente até atingir um pico máximo em 30 minutos após sua administração, correspondendo a aproximadamente $49 \%$ da dose, ocorrendo uma lenta depuração até 48 horas após a administração do fármaco, alcançando níveis de $7 \%$ da dose. Para o antimoniato de meglumina lipossomal, o nível mais alto de fármaco foi verificado $5 \mathrm{~h}$ 
depois da injeção, correspondendo a $34 \%$ da dose. Nos tempos iniciais de avaliação os níveis de antimônio foram significativamente menores em comparação com o AMI, porém ocorreu a sustentação da dose por tempo prolongado, onde após 48 horas, foi observado cerca de 2 vezes maior.
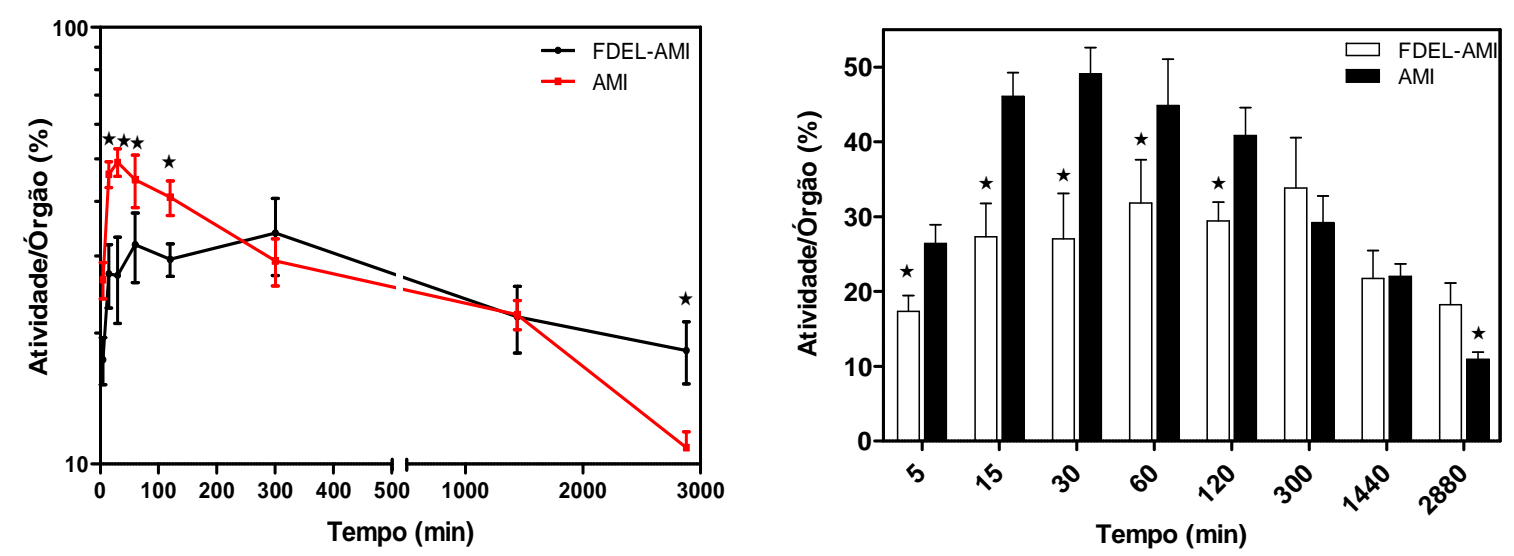

FIGURA 34 - Biodistribuição do antimônio no fígado de camundongos sadios, após a injeção intraperitoneal das formulações de antimoniato de meglumina irradiado encapsulado em lipossomas (FDEL-AMI) e antimoniato de meglumina irradiado livre (AMI). Os dados são indicados como média \pm desvio padrão $(\mathrm{n}=5)$. $\star=$ diferença estatisticamente significante entre as formulações $(\mathrm{P}<0,05)$.

Os dados de maior captação do fármaco pelo fígado corroboram com os dados verificados por outros autores e estão associados com um efeito antiparasitário. Collins e colaboradores (1992) verificaram alta concentração dos níveis de antimônio no fígado e significante supressão do parasito, em relação aos outros órgãos avaliados (baço e medula óssea), quando foi administrado estibogluconato de sódio via intravenosa em camundongos sadios e infectados com $L$. donovani. Este resultado sugere que o pico de antimônio tecidual alcançado rapidamente após a dosagem é um fator importante para determinar a eficácia do fármaco num local particular da infecção. Em outro estudo, foi administrado estibogluconato de sódio livre e lipossomal via intramuscular em camundongo sadio e após 24 horas verificou-se que no fígado estava presente o nível mais alto de antimônio tecidual (Hunter et al., 1988). Os altos níveis de antimônio no fígado podem ser explicados pela alta taxa de perfusão sangüínea (Carter et al., 1988).

Foi verificado que o efeito antiparasitário do estibogluconato de sódio é dependente do local de ação (Carter et al., 1988) e do estágio da infecção (Baillie et al., 1989). Não foi verificada correlação entre a supressão parasitária e os níveis de antimônio 
presentes no fígado e baço de hamsters infectados com $L$. donovani e tratados com diferentes agentes antimoniais (Gellhorn \& Van Dyke, 1946). Collins e colaboradores (1992) também observaram que em camundongos com infecção aguda e tratados com estibogluconato de sódio ocorreu significante supressão do parasito somente no fígado, apesar dos níveis de antimônio serem altos tanto no baço como na medula óssea. Na infecção crônica a ausência da supressão parasitária no fígado está de acordo com os níveis de antimônio, os quais são menores do que na infecção aguda (Collins et al., 1992).

Os resultados obtidos neste estudo corroboram com os registros anteriores, demonstrando que os agentes antimoniais encapsulados em lipossomas apresentam alta afinidade pelos órgãos do SMF, sendo extremamente efetivos na supressão do parasita. Alving e colaboradores (1978 a, b) reportaram que ambos antimoniais pentavalentes (estibogluconato de sódio e antimoniato de meglumina) encapsulados em lipossomas foram centenas de vezes mais ativos que a fármaco livre. Os autores verificaram que a dose necessária para obter $50 \%$ de supressão parasitária no fígado de hamsters infectados com L. donovani foi aproximadamente 350 - 900 vezes menor comparando com o fármaco livre. Resultados similares foram observados por New e colaboradores (1978), utilizando lipossomas com diferentes agentes antimoniais obtiveram supressão parasitária em camundongos portadores de leishmaniose visceral experimental, com aumento da atividade antileishmania dos compostos encapsulados em lipossomas.

Foi observado aumento do efeito terapêutico quando os antimoniais pentavalentes encapsulados em lipossomas foram injetados pela via intracardíaca, intramuscular ou intraperitoneal, mas não quando administrados pela via oral ou subcutânea (Alving et al., 1980). Além dos lipossomas permitirem a redução de fármaco necessária para o tratamento da infecção, eles provocaram uma diminuição na taxa de morte entre os animais doentes (Alving et al., 1984). Chapman e colaboradores (1984) trataram cachorros portadores de leishmaniose visceral experimental utilizando uma formulação de antimoniato de meglumina lipossomal e, observaram 89 - $96 \%$ de redução do parasito no baço, mostrando que a eficácia da formulação lipossomal era 700 vezes superior ao fármaco não encapsulado.

Tem sido demonstrada a eficácia do antimoniato de meglumina encapsulado em lipossomas liofilizados no tratamento de hamsters experimentalmente infectados com L. (L.) chagasi, onde verificaram uma significante redução do parasito no fígado destes animais, além disso, observaram que a fármaco livre era ineficiente quando administrada em doses comparáveis de antimônio (Frézard et al., 2000). 
Os altos níveis hepáticos do antimoniato de meglumina encapsulado em lipossomas por longo período podem ser atribuídos ao rápido acúmulo do fármaco no fígado e, lenta liberação do fármaco pelo lipossoma. Tem sido demonstrado que após a administração parenteral, os lipossomas são capturados preferencialmente por macrófagos do baço e fígado. Especialmente lipossomas constituídos de fosfatidilserina são eficientemente eliminados do sangue pelas células do SMF, predominantemente células de Kupffer e hepatócitos no fígado. Um importante papel deste mecanismo de captação tem sido atribuído as proteínas do soro, referidas como opsoninas (Scherphof et al., 2001). Além disso, a mimetização de uma célula apoptótica, devido à inclusão de fosfatidilserina na membrana lipídica dos lipossomas, mostrou um significativo aumento da eficácia in vivo, reduzindo 133 vezes a dose total de antimônio, com diminuição de $100 \%$ da carga parasitária no fígado de camundongos portadores de leishmaniose visceral (Tempone \& Andrade, 2008).

Ambas as formulações de antimoniato de meglumina livre e lipossomal demonstraram ser absorvidas pelo trato gastrointestinal (FIG. 35) e, serem eliminadas preferencialmente pela via hepática por excreção biliar. A absorção do fármaco ocorreu no estômago, com um pico da dose nos 5 minutos iniciais da injeção. Para o AMI, no período seguinte ocorreu um decréscimo da dose, seguido da elevação dos níveis de antimônio nas próximas 1 - 2 horas e então, iniciou-se o processo de eliminação. Para o FDEL-AMI, no período seguinte também ocorreu um decréscimo da dose, porém seguido da elevação dos níveis de antimônio nas próximas 5 horas e a conservação da dose por tempo prolongado (FIG. 35 A).

No intestino delgado foi observado um decaimento significativo dos níveis de antimônio nas 2 horas seguidas da administração da dose (FIG. 35 B). No mesmo momento, foi verificado um aumento significativo da dose no intestino grosso, representando a passagem do fármaco metabolizada pelo fígado para o intestino delgado e em seguida para o intestino grosso, para poder ser eliminada nas fezes. A fase de eliminação biliar, no intestino grosso, possivelmente ocorreu nas 2 horas iniciais, atingindo o pico 5 horas após a dose injetada e, iniciou-se a fase lenta de eliminação por até 24 horas após a dose administrada. Esses valores corroboram com os dados apresentados pela captação do fármaco pelo fígado, onde foi verificado que neste mesmo período ocorreu o decaimento da dose injetada, equivalente à concentração eliminada pelo intestino. Além disso, após as 24 horas iniciais da administração do fármaco possivelmente ocorreu uma 
fase bastante lenta de eliminação pela via renal e biliar permanecendo por mais de 48 horas após a injeção (FIG. 35 C e D).
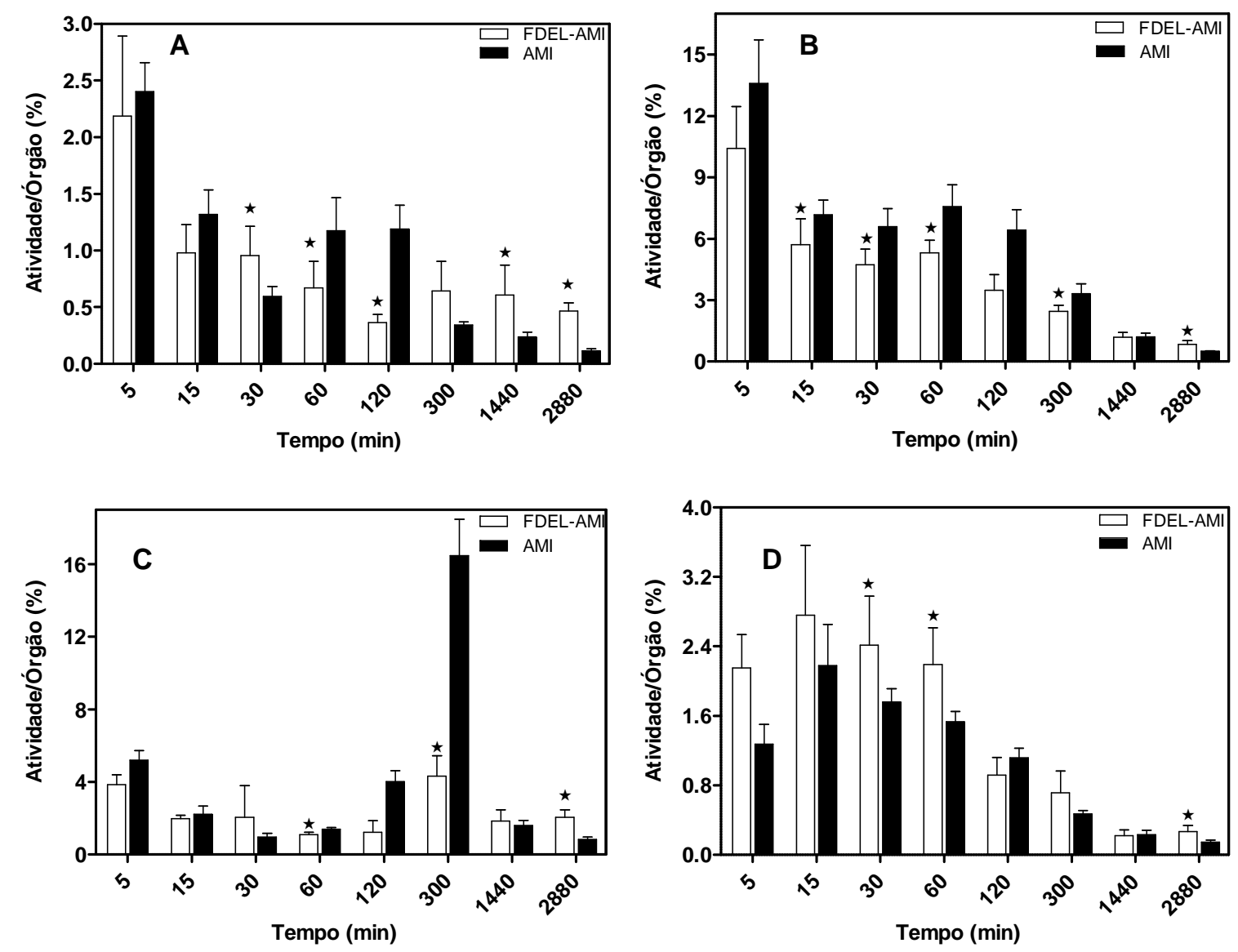

FIGURA 35 - Biodistribuição do antimônio em camundongos sadios, após a injeção intraperitoneal das formulações de antimoniato de meglumina irradiado encapsulado em lipossomas (FDEL-AMI) e antimoniato de meglumina irradiado livre (AMI). (A) estômago; (B) intestino delgado; (C) intestino grosso; (D) rins. Os dados são indicados como média \pm desvio padrão $(\mathrm{n}=$ 5). $\star=$ diferença estatisticamente significante entre as formulações $(\mathrm{P}<0,05)$.

Neste trabalho foi verificado que ambas as formulações de antimoniato de meglumina livre e lipossomal apresentaram eliminação renal extremamente rápida, cerca de 5 - 15 minutos após a administração do fármaco (FIG. 36). Durante as 24 horas iniciais, ocorreu uma fase lenta de eliminação do fármaco, seguida de uma fase mais lenta, permanecendo por mais de 48 horas após a injeção. 

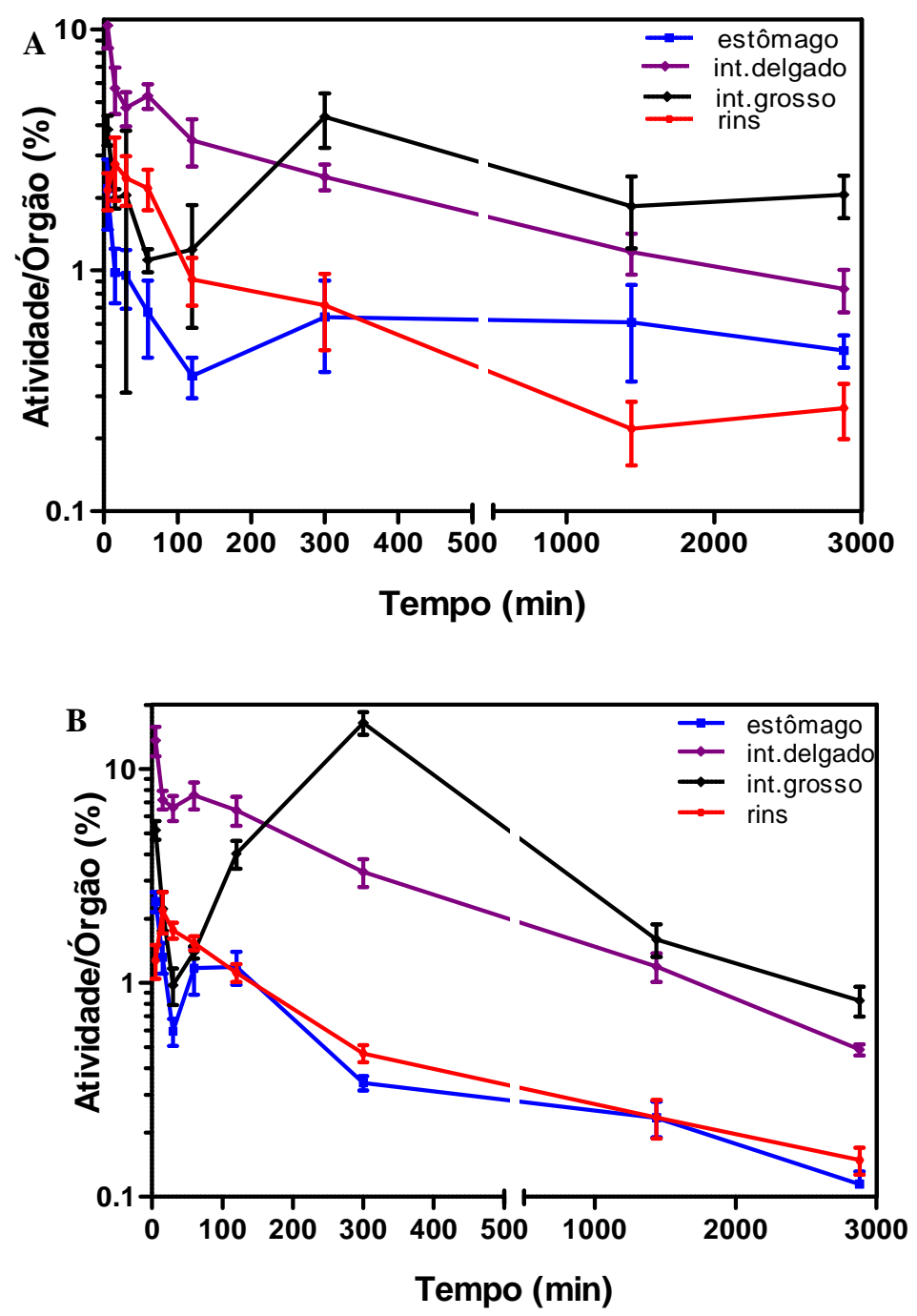

FIGURA 36 - Farmacocinética do antimônio em camundongos sadios, após a injeção intraperitoneal da formulação de: (A) antimoniato de meglumina irradiado encapsulado em lipossomas (FDEL-AMI); (B) antimoniato de meglumina irradiado livre. Os dados são indicados como média \pm desvio padrão $(\mathrm{n}=$ $5)$.

Neste estudo as formulações demonstraram ser absorvidas pelo trato gastrointestinal e, assim, obrigatoriamente vão até o fígado através da veia porta, onde são biotransformadas e ocorre o efeito de primeira passagem, para então alcançar o restante do corpo. Na reação de fase 1 de biotransformação, em geral, ocorre a conversão do medicamento original em um metabólito mais polar por oxidação, redução ou hidrólise e, o metabólito resultante pode ser mais ativo que a molécula original - pró-fármaco (Florio, 2002). Muitos estudos vêm sugerindo que o antimonial pentavalente seja um pró-fármaco, uma vez que necessita ser bioconvertido para a forma trivalente para desempenhar sua ação antileishmania (Roberts et al., 1995). 
Depois de biotransformado o fármaco pode ser eliminado do organismo, neste caso, a eliminação do antimoniato de meglumina irradiado livre e lipossomal representaram ser preferencialmente pela via hepática por excreção biliar (FIG. 35 e FIG. 36). Os fatores que determinam esta forma de excreção incluem o tamanho e a polaridade da molécula do medicamento a ser eliminado. Medicamentos com massa molecular elevado (> 300), têm grande probabilidade de serem excretados pela bile. A excreção pela bile tem importância também na eliminação de substâncias orgânicas polares que não são reabsorvidas pelo intestino (cátions e ânions orgânicos) (Florio, 2002).

$\mathrm{O}$ antimoniato de meglumina livre e lipossomal mostraram uma leve e rápida eliminação renal. Esses dados corroboram os resultados reportados por Otto e Maren (1950) que verificaram relativamente à mesma quantidade de antimônio pentavalente excretado nas fezes e urina de camundongos que receberam uma única dose de Solustibosan (antimônio pentavalente) e, analisando a excreção em diferentes espécies de mamíferos verificaram que os níveis mais altos de excreção de antimônio pentavalente estavam nas fezes de camundongos. Porém, tem sido aceito que os agentes antimoniais pentavalentes são eliminados preferencialmente pela via renal, com rápida eliminação, uma vez que foi verificado que entre 80 - $91 \%$ da dose administrada de Pentostam foi excretada na urina, entre 6 - 8 h após a injeção via intramuscular e $96 \%$ da dose administrada foi excretada na urina, nas 6 h após a injeção via intravenosa (Rees et al., 1980).

Apesar da via de excreção dos antimoniais pentavalentes encapsulados em lipossomas não ter sido reportada em outros trabalhos, a deposição hepática e a lenta liberação do fármaco das células SMF, acreditava-se num favorecimento do mecanismo biliar de excreção. A diferença entre os dados mostrados neste trabalho e os apresentados pela literatura pode ser explicada pela ausência de registro sobre análise da biodistribuição de antimônio pentavalente em órgãos que participam da via de eliminação êntero-hepática, especialmente intestinos e vesícula biliar. Além disso, não há análise de antimônio nas fezes, pois somente há descrição da avaliação de alguns órgãos como baço, fígado, medula óssea e pele (Lugo de Yarbuh et al., 1994; Al Jasser et al., 1995), análise de urina (Miekeley et al., 2002; Rees et al., 1980) e sangue (Otto et al., 1947; Chulay et al., 1988; Pamplim et al., 1981). Estes fatos reiteram a necessidade eminente de mais estudos para poder esclarecer a farmacocinética do antimônio pentavalente livre e lipossomal.

Recentemente foi demonstrado o mesmo perfil de biodistribuição do antimoniato de meglumina livre entre os animais sadios e infectados com L. (L.) chagasi, com diferenças na concentração da dose presente em cada um deles, onde os animais 
sadios apresentaram maiores níveis de antimônio no fígado em relação aos animais infectados, e o contrário foi verificado no intestino, onde os animais infectados apresentaram maiores níveis de antimônio em relação aos animais sadios (Borborema et al., 2005 b).

As curvas de decaimento sérico para ambas as formulações apresentaram similaridade. A farmacocinética de antimônio no sangue foi representada num modelo biexponencial aberto (FIG. 37).

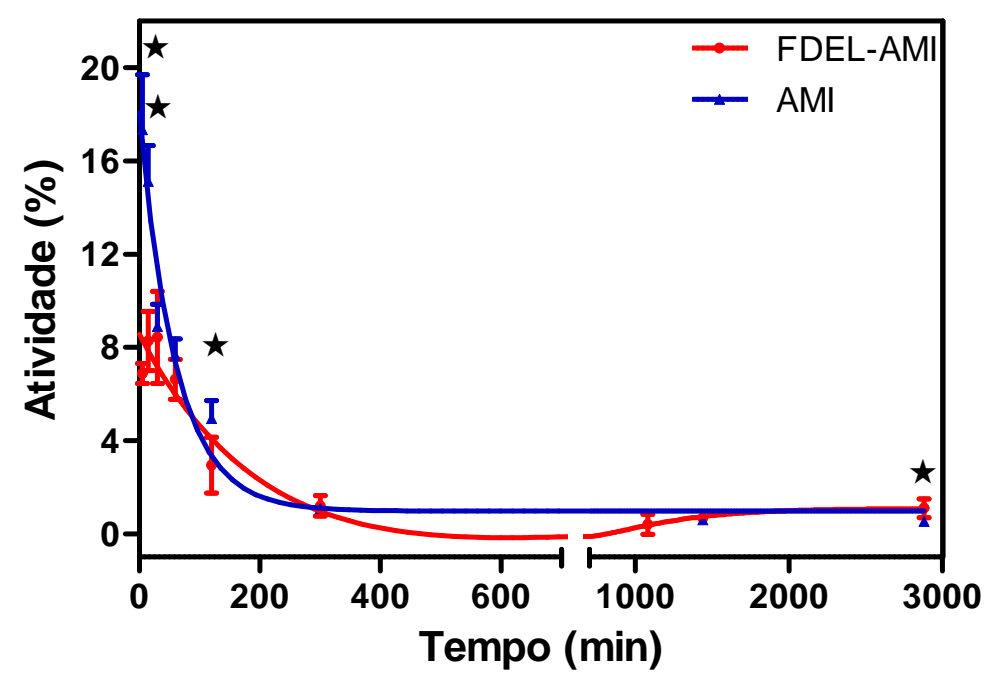

FIGURA 37 - Farmacocinética do antimônio no sangue de camundongos sadios, após a injeção intraperitoneal das formulações de antimoniato de meglumina irradiado encapsulado em lipossomas (FDEL-AMI) e antimoniato de meglumina irradiado livre (AMI). Os dados são indicados como média \pm desvio padrão $(n=5)$. $\star=$ diferença estatisticamente significante entre as formulações $(\mathrm{P}<0,05)$.

A absorção dos lipossomas, após a administração intraperitoneal, ocorreu nos primeiros 30 minutos. Já o antimoniato de meglumina livre apresentou maior porcentagem de absorção do fármaco, com o pico da concentração de antimônio de aproximadamente 17 $\%$ da dose administrada nos cinco minutos iniciais. Porém o processo de distribuição e eliminação demonstrou ser mais rápido. O processo de distribuição do fármaco para outros compartimentos ocorreu entre os 30 e 60 minutos iniciais da administração para o FDELAMI e entre os 15 e 60 minutos para o AMI. A eliminação de antimônio no sangue ocorreu entre os 60 e 300 minutos após a administração, mostrando uma primeira fase de decaimento rápido. Em seguida, iniciou-se uma segunda fase de eliminação mais lenta. $\mathrm{O}$ primeiro destes compartimentos cinéticos hipotéticos representa um compartimento central 
que inclui o sangue, o volume em que a fármaco é absorvida, seguida da excreção do fármaco através da urina. O segundo compartimento pode representar um compartimento periférico em que a fármaco é distribuída e finalmente eliminada por excreção biliar. Apesar dos processos de absorção e distribuição do antimoniato de meglumina livre serem mais rápidos, a formulação encapsulada demonstrou maior predominância de antimônio no sangue mesmo após 48 horas da administração.

Pelo menos uma das duas fases observadas no sangue deve corresponder à captura do lipossoma pelos órgãos do SMF, uma vez que mais de $45 \%$ do antimônio administrado foi verificado no fígado e baço. Além disso, foi observado um aumento da quantidade de fármaco nos órgãos do SMF ao mesmo tempo em que houve uma redução no sangue.

A fim de comparar a afinidade relativa do antimoniato de meglumina irradiado por diferentes órgãos, foram analisados os dados de biodistribuição através de cálculo da porcentagem da dose administrada por grama de órgão, para se anular aparente captação que ocorre em órgãos que possuem maior massa.

Após a avaliação de todos os órgãos, foi possível verificar que as diferenças mais significativas na captação do antimônio ocorreram no baço (FIG. 38). Cabe ressaltar a elevada distribuição de antimônio no baço e fígado, órgãos que são conhecidos por abrigarem o parasito Leishmania e também responsáveis pela rápida absorção de lipossomas. De acordo com esses dados, a formulação lipossomal promoveu um direcionamento seletivo do antimônio para tecidos do SMF, além do que manteve as doses elevadas nos órgãos por um período prolongado (Borborema et al., 2009). 

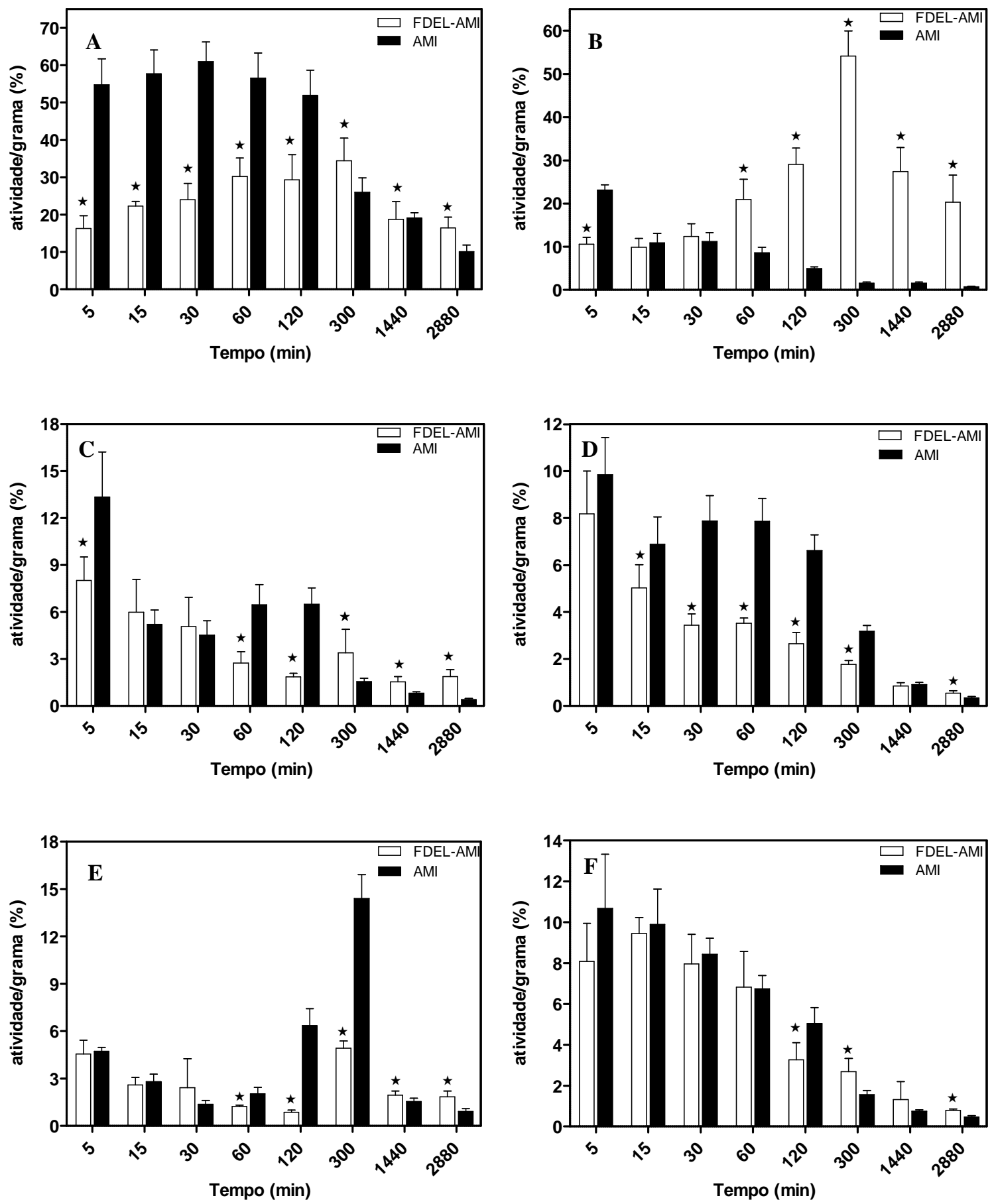

FIGURA 38 - Biodistribuição do antimônio em camundongos sadios, após a injeção intraperitoneal das formulações de antimoniato de meglumina irradiado encapsulado em lipossomas (FDEL-AMI) e antimoniato de meglumina irradiado livre (AMI). (A) fígado; (B) baço; (C) estômago; (D) intestino delgado; (E) intestino grosso; (F) rins. Os dados são indicados como média \pm desvio padrão $(\mathrm{n}=5) . \star$ diferença estatisticamente significante entre as formulações $(\mathrm{P}<0,05)$. 
Os resultados observados da elevada presença de antimônio no baço após a administração da formulação lipossomal e sua sustentação por tempo prolongado corroboram com os dados reportados por Schettini e colaboradores (2003, 2006). Porém, neste estudo, os altos níveis de fármaco foram alcançados mais rapidamente, durante as 5 horas iniciais da administração.

No presente trabalho não foram observados os dados de captação das formulações de antimônio livre ou lipossomal na medula óssea. Contudo, tem sido evidenciada a importância deste órgão no controle e na eliminação do parasito durante a infecção. Foi demonstrada a elevação do nível de antimônio e redução do número de parasitos na medula óssea de cachorros naturalmente portadores de leishmaniose visceral tratados com injeções múltiplas intravenosas de antimoniato de meglumina encapsulado em lipossomas liofilizados, mas não foi eficiente na eliminação dos parasitos (Schettini et al., 2005). Utilizando antimoniato de meglumina encapsulado em lipossomas de tamanho reduzido (aproximadamente $400 \mathrm{~nm}$ ) no tratamento de cachorros naturalmente infectados com L. (L.) chagasi foi observado uma significante elevação dos níveis de antimônio teciduais nos órgãos do SMF e, ainda uma elevação de aproximadamente três vezes dos níveis de antimônio na medula óssea quando comparado com os lipossomas de maior tamanho $(1200 \mathrm{~nm})$, sugerindo que a redução do tamanho dos lipossomas promoveu uma maior captação pela medula óssea, órgão crítico na cura da Leishmaniose (Schettini et al., 2006).

Recentemente, foi relatada uma análise dos efeitos tóxicos do antimoniato de meglumina encapsulado em lipossomas no tratamento de cães naturalmente infectados com L. (L.) chagasi. A avaliação dos marcadores sanguíneos de função hematopoiética, hepática e renal não indicou alterações. Reações adversas transitórias, incluindo prostração, defecação, taquipnéia e sialorréia foram observadas durante os primeiros 15 minutos da administração. Entretanto, 5 meses após o tratamento, verificaram supressão parasitária significante em órgãos como fígado, baço e linfonodos e, redução da infecção de mosquitos que se alimentaram destes animais (Ribeiro et al., 2008).

Foi verificado que as curvas de decaimento sérico para ambas as formulações de antimoniato de meglumina livre e lipossomal são similares (FIG. 39). O pico da concentração de antimônio no sangue foi conseguido 5 minutos após a administração pela via intraperitoneal. Possivelmente esse período corresponde à fase inicial de absorção do fármaco, e, então, iniciou-se uma fase de distribuição ligada a uma etapa com predomínio de eliminação rápida até 5 horas após a dose administrada. Em seguida, iniciou-se uma 
fase de eliminação lenta, alcançando níveis de antimônio de 0,4 e 0,8 \% da dose administrada de AMI e FDEL-AMI, respectivamente, após 48 horas.

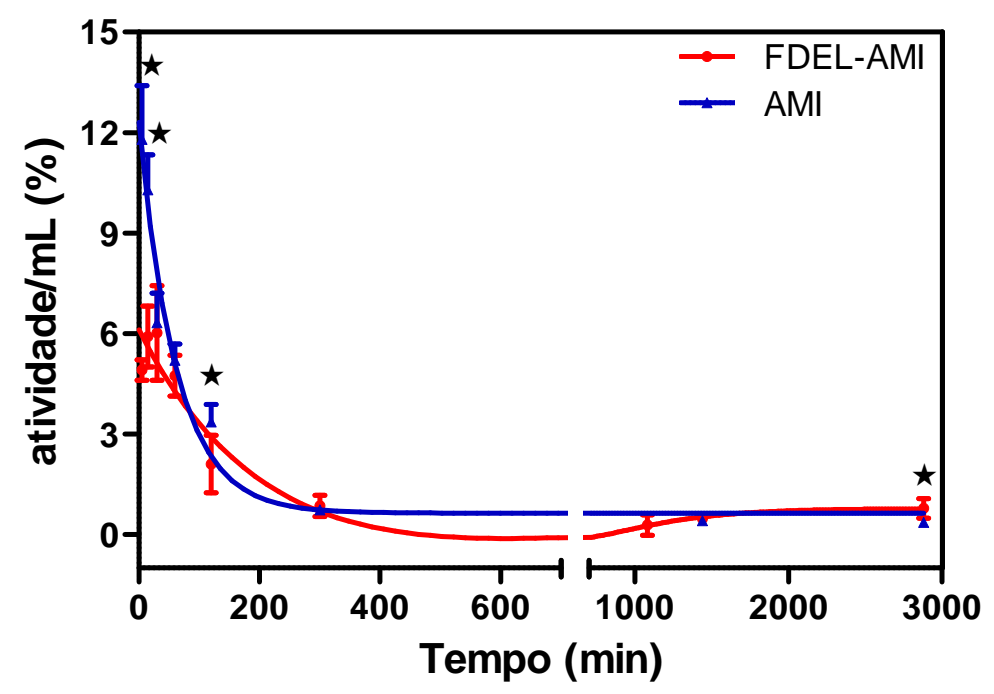

FIGURA 39 - Farmacocinética do antimônio no sangue de camundongos sadios, após a injeção intraperitoneal das formulações de antimoniato de meglumina irradiado encapsulado em lipossomas (FDEL-AMI) e antimoniato de meglumina irradiado livre (AMI). Os dados são indicados como média \pm desvio padrão $(n=5)$. $\star=$ diferença estatisticamente significante entre as formulações $(\mathrm{P}<0,05)$.

A farmacocinética do antimônio pentavalente (Pentostam) no sangue humano tem sido registrada em alguns trabalhos (Chulay et al., 1988), os quais corroboram com os dados obtidos neste estudo. A curva de decaimento sérico é descrita melhor por um modelo farmacocinético de dois compartimentos. O primeiro deste compartimento cinético hipotético representa um compartimento central incluindo o sangue, volume no qual a fármaco é absorvida após injeção intraperitoneal, e do qual a fármaco é rapidamente excretada via renal. $\mathrm{O}$ segundo compartimento representa um compartimento periférico dentro do qual a fármaco é distribuída ou aonde pode ocorrer à conversão in vivo (no fígado) do antimônio pentavalente para a forma trivalente, com uma rápida excreção renal do antimônio pentavalente, seguido de uma fase mais lenta podendo corresponder à eliminação do antimônio trivalente (Chulay et al., 1988; Valladares et al., 1996). Sugere-se que o antimônio pentavalente possa ser um pró-fármaco, sendo convertido a antimônio trivalente após sua administração (Frézard et al., 2001). Esses resultados reforçam a hipótese de uma conversão metabólica intramacrofágica do antimônio pentavalente em antimônio trivalente, sendo este o elemento tóxico ao parasita no seu estado intracelular, já 
que o antimônio pentavalente é dez vezes menos tóxico para os humanos e tem um maior índice terapêutico que as preparações de antimônio trivalente (Roberts et al., 1995).

O perfil do clareamento sanguíneo do antimônio lipossomal corrobora com os dados reportados por Valladares e colaboradores (2001). Os autores demonstraram após o tratamento de cães portadores de leishmaniose visceral com antimoniato de meglumina livre e lipossomal uma curva plasmática com duas fases, sendo a fase inicial com decréscimo rápido da concentração, correspondendo à distribuição, seguido de uma segunda fase lenta representando a eliminação do fármaco. Porém, a concentração plasmática de antimônio foi maior quando usada a formulação lipossomal, promovendo elevação e manutenção dos níveis por período prolongado.

A determinação da farmacocinética permitiu verificar o tempo de permanência do fármaco no organismo, bem como avaliar seu período de ação, visto que não se sabe ao certo se para o tratamento da leishmaniose, o pico da concentração de antimônio demonstra ser mais importante (Berman et al., 1988; Valladares et al., 1997) do que a manutenção dos níveis totais de antimônio por um longo período (Chulay et al.,1988; Tassi et al., 1994).

É necessário ressaltar que diferenças metodológicas entre os inúmeros trabalhos relacionados à terapia e análise farmacocinética dos fármacos empregados no tratamento das leishmanioses, acarretam dificuldades quando se comparam os dados de efetividade e de biodistribuição (Hunter et al., 1988). Modificações na via de administração do fármaco, na concentração do fármaco, tipo de formulação estudada, estágio de infecção, espécie usada, composição lipídica, tamanho e estrutura dos lipossomas são alguns dos fatores que provocam estas alterações entre os dados apresentados na literatura.

De acordo com os resultados da biodistribuição do antimoniato de meglumina encapsulado em lipossomas contendo fosfatidilserina, a fármaco lipossomal promoveu um acentuado direcionamento do antimônio para tecidos SMF, além disso, manteve as doses elevadas nos órgãos por período prolongado. O desenvolvimento de formulações lipossomais pode ser uma nova alternativa para a quimioterapia de doenças infecciosas, especialmente as Leishmanioses, envolvendo o SMF, já que são usados como sistemas carreadores para entrega sustentada e direcionada de fármacos ao local da infecção.

Nestes estudos foi demonstrado que a utilização de radiotraçadores de antimônio desenvolvidos pela irradiação com nêutrons apresentou alta sensibilidade de detecção, além de ter sido uma análise simples e relativamente rápida. Enquanto, a 
metodologia analítica descrita na literatura para a determinação de antimônio baseia-se, principalmente em métodos colorimétricos, espectrométricos e voltamétricos, demorados e de elevado custo, sendo inviáveis para o estudo de um grande número de amostras (Petit de Peña et al., 1990). 


\section{DISCUSSÃO}

Este estudo abrangeu o desenvolvimento de um sistema de entrega de medicamentos, com controle de qualidade de sua composição e elucidação de seu efeito sobre leishmanias, células normais e infectadas e em animais experimentais, com estudo de sua biodistribuição e compartimentalização no hospedeiro. A opção foi comentar cada resultado individualmente quando de sua apresentação e aqui discutir a importância e a avaliação crítica deste produto.

A Leishmaniose Visceral está presente especialmente em países denominados subdesenvolvidos ou em desenvolvimento e, está entre as doenças ditas negligenciadas, por apresentar pouco ou nenhum investimento e interesse pela indústria farmacêutica privada. Várias iniciativas estatais ou de órgãos mundiais (DNDi, 2010) tem tentado achar soluções para esta enfermidade, diante da ausência de poder aquisitivo significativo das populações afetadas, que geralmente estão entre as mais pobres dos países pobres. Estes fatores ressaltam a necessidade imperativa do desenvolvimento de novos agentes terapêuticos para esta enfermidade, como o que aqui apresentado.

O conhecimento de que os lipossomas são eficientes sistemas de transporte de medicamentos e promovem a melhora da eficácia com redução da toxicidade, além do que podem ser preparados com fosfolipídios específicos para o direcionamento de fármacos para o sistema mononuclear fagocitário, serviu como uma ferramenta bastante poderosa para entrega dos agentes antimoniais aos macrófagos. Apesar de parecer de alto custo, a produção de lipossomas estáveis liofilizados, como aqui demonstrados, permite a sua reidratação em locais de campo, possibilitando seu uso em locais distantes e com menor infraestrutura de saúde, frequente em zonas endêmicas (Murray et al., 2005). A alta eficiência terapêutica da formulação lipossomal permite supor que um número menor de doses e de antimônio poderia ser utilizado no tratamento, diminuindo os custos com hospitalização e o número de intervenções por paciente.

A colaboração e intercâmbio entre diferentes laboratórios e instituições, formados por uma equipe de grande competência cientifica e tecnológica, com uma visão integrada e multidisciplinar, possibilitou o desenvolvimento deste sistema terapêutico para as leishmanioses. A execução do trabalho científico, que gerou esta tese de doutoramento, proporcionou um grande número de experiências em pesquisa, mostrando a capacidade 
nacional, além de contribuir para a ampliação e melhoria da produção científica e tecnológica e desenvolveu competências para a pesquisa e inovação.

Este estudo apresenta inúmeros aspectos inéditos ou de inovação e é difícil optar pela discussão como um todo ou ainda focalizar em pontos específicos. O uso do Reator Nuclear para produção de radioisótopos de antimônio, pela irradiação do antimoniato de meglumina, um fármaco comercial, e usá-lo como radiotraçadores para realização de estudos de biodistribuição foi essencial para este trabalho e, caso houvesse colimadores adequados até estudos de imagem poderiam ser realizados, como acontece com outros radioisótopos e/ou radiofármacos de menor energia. Isto demonstra que para cada problema várias soluções podem ser tentadas e que a energia nuclear pode contribuir sobremaneira para a ciência, em um uso pacífico e benéfico na farmacologia e medicina. Neste caso, prenuncia novas abordagens para uso de sistemas transportadores de radioisótopos tanto para diagnóstico como para terapia, graças ao uso conjunto de radioisótopos e lipossomas (Koo et al., 2005).

O uso de diversas metodologias para a determinação de antimônio possibilitou o conhecimento e a comparação da eficiência entre elas. A Análise por Ativação Neutrônica mostrou-se a técnica mais eficiente para a quantificação de antimônio no antimoniato de meglumina livre e lipossomal, especialmente na determinação em diferentes etapas da produção, permitindo alcançar limites muito mais precisos de quantificação, quando comparada aos sistemas convencionais de espectrometria e espctrofotometria. Para cada método há uma escolha e o mais importante foi dispor de todos para a execução deste estudo, usados de forma crítica e comparativa.

Neste estudo foi demonstrado um elevado aumento da eficácia do antimoniato de meglumina encapsulado em lipossomas comparando com a forma livre no tratamento in vitro das leishmanioses, com melhora do índice terapêutico. A captação do antimoniato de meglumina lipossomal foi superior em macrófagos infectados. Apesar dos estudos investigativos in vitro serem importantes para a avaliação da interação do fármaco, citotoxicidade e atividade, somente os estudos in vivo podem mostrar a interação dos lipossomas no ambiente verdadeiro. Neste sentido, o aprimoramento de um tratamento mais efetivo poderia ser realizado em animais portadores de leishmaniose para a avaliação da atividade terapêutica do antimoniato de meglumina encapsulado em lipossomas, para determinação do melhor regime de dose, via de administração, tempo de tratamento. Além disso, a combinação/associação terapêutica mostra-se como uma abordagem bastante 
eficaz para a melhoria do tratamento, podendo diferentes fármacos ser encapsulados nos lipossomas ou ainda usados conjuntamente.

Este estudo, além de apresentar resultados diretos para o tratamento da Leishmaniose, enfatiza o uso potencial dos sistemas de entrega de fármacos, como lipossomas para tratar doenças infecciosas que envolvem o SMF. Oferece uma abordagem útil como sistema radiofarmacológico para avaliação de vários tipos de lipossomas com diferentes características físico-químicas.

A "sede" do saber, conhecer, investigar, pesquisar, desenvolver... possibilitou que inúmeras instituições contribuíssem com pouco e com muito, desde a doação de lipídios pela Lipoid, o uso de reatores atômicos para produzir isótopos específicos, as formas sofisticadas de dosagem e a comparação entre técnicas sofisticadas e outras semiquantitativas mostraram que é possível responder algumas das muitas questões existentes... 


\section{CONCLUSÕES}

Neste trabalho foi desenvolvida uma formulação de antimoniato de meglumina lipossomal, constituída de fosfatidilserina, captada preferencialmente pelo sistema mononuclear fagocitário e, foi determinada sua farmacocinética em animais sadios.

Especificamente, pode-se concluir que:

1. Os métodos espectrométricos e espectrofotométricos necessitaram de decomposição química das amostras, com baixa repetibilidade e acurácia na quantificação do antimônio total.

2. A Análise por Ativação Neutrônica, devido à maior precisão e confiabilidade, foi reconhecida como o método de escolha para determinação qualitativa e quantitativa de antimônio em todas as amostras.

3. A irradiação do fármaco antimoniato de meglumina resultou na produção de dois radiotraçadores isotópicos de antimônio: ${ }^{122} \mathrm{Sb}$ e ${ }^{124} \mathrm{Sb}$. O composto irradiado apresentou alta pureza radionuclídica, com boa atividade específica e com características fisiológicas para realizar os estudos de biodistribuição.

4. Foram desenvolvidas três formulações de antimoniato de meglumina encapsulado em lipossomas com tamanho de diâmetro médio de $150 \mathrm{~nm}$, sendo vesículas multilamelares.

5. A formulação AM-PS-FTL apresentou a maior eficiência de encapsulação, enquanto a formulação AM-FDEL mostrou a maior capacidade de recuperação do fármaco.

6. As formas promastigotas de Leishmania sp. não apresentam suscetibilidade ao antimoniato de meglumina livre ou encapsulado em lipossomas.

7. As formulações lipossomais foram dezenas de vezes mais eficientes contra as formas amastigotas de Leishmania sp. do que o fármaco livre, apresentando alto índice de seletividade.

8. A internalização dos lipossomas marcados com fluorescência foi mais rápida em macrófagos infectados, durante um tempo curto e inicial de incubação, em comparação com os macrófagos não infectados. 
9. A associação e ligação dos lipossomas foram mais intensas nos macrófagos não infectados, nos primeiros tempos avaliados.

10. O método FDEL mostrou ser um procedimento simples, fácil, reprodutível e com excelente recuperação do fármaco. Desta forma, foi preconizado para ser utilizado nos estudos de biodistribuição com radiotraçadores de antimônio.

11. A biodistribuição do antimoniato de meglumina encapsulado em lipossomas contendo fosfatidilserina revelou que a fármaco lipossomal promoveu um acentuado direcionamento do antimônio para tecidos do SMF e, manteve as doses elevadas nos órgãos por período prolongado.

12. A distribuição biológica do antimoniato de meglumina lipossomal, por via intraperitoneal, revelou que os órgãos de maior captação são representados pelo fígado e baço.

13. O mesmo perfil de biodistribuição do antimoniato de meglumina livre e lipossomal foi verificado entre os animais sadios.

14. Ambas as formulações de antimoniato de meglumina livre e lipossomal apresentaram eliminação preferencialmente pela via hepática por excreção biliar, uma pequena e rápida eliminação renal.

15. A curva de decaimento sérico de ambas as formulações foi representada por um modelo bicompartimental; 


\title{
ANEXO A- Aprovação do Comitê de Ética em Pesquisa do IMTSP
}

\author{
UNIVERSIDADE DE SÃO PAULO \\ INSTITUTO DE MEDICINA TROPICAL DE SÃO PAULO \\ Av. Dr. Enéas de Carvalho Aguiar, 470 \\ CEP 05403-000 - São Paulo - Brasil \\ Telefone:(55-11)3061-7066 e 3064-5132 FAX: (55-11) 3064-5132 e 3062-2174
}

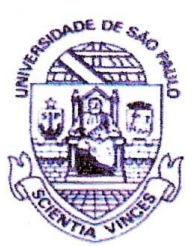

São Paulo, 08 de maio de 2008.

Ilma

Samanta Etel Treiger Borborema

Em reunião na presente data, o Comitê de Ética em Pesquisa do Instituto de Medicina Tropical de São Paulo da Universidade de São Paulo analisou e aprovou, no que diz respeito aos aspectos de natureza da ética em Pesquisa, o projeto classificado sob o número CEP-IMTSP/012/29042008, intitulado "Desenvolvimento e farmacocinética de antimônio encapsulado em lipossomas de fosfatidilserina utilizando radioisótopos em leishmaniose experimental" sob a responsabilidade do Dr Heitor Franco de Andrade Jr.

Atenciosamente

Dra. Eufrosina Setsu Umezawa

Coordenadora do CEP-IMTSP/USP

Dra. Eufrosina Setsu Umezawa Coordenadora da Comissle de Etica em Pesquisa 
ANEXO B - Tabela de biodistribuição do FDEL-AMI e AMI

\begin{tabular}{|c|c|c|c|c|}
\hline Amostra & Tempo (min) & Órgão & Atividade/órgão (\%) & DP \\
\hline AMI & 5 & baço & 1,639 & 0,120 \\
\hline FDEL-AMII & 5 & baço & 1,010 & 0,383 \\
\hline AMI & 15 & baço & 0,762 & 0,144 \\
\hline FDEL-AMII & 15 & baço & 1,145 & 0,218 \\
\hline AMI & 30 & baço & 0,626 & 0,092 \\
\hline FDEL-AMII & 30 & baço & 1,322 & 0,375 \\
\hline AMI & 60 & baço & 0,840 & 0,094 \\
\hline FDEL-AMII & 60 & baço & 2,256 & 0,491 \\
\hline AMI & 120 & baço & 0,435 & 0,088 \\
\hline FDEL-AMII & 120 & baço & 3,957 & 0,587 \\
\hline AMI & 300 & baço & 0,154 & 0,037 \\
\hline FDEL-AMII & 300 & baço & 6,005 & 0,957 \\
\hline AMI & 1440 & baço & 0,163 & 0,019 \\
\hline FDEL-AMII & 1440 & baço & 3,717 & 0,974 \\
\hline AMI & 2880 & baço & 0,093 & 0,019 \\
\hline FDEL-AMII & 2880 & baço & 2,683 & 0,311 \\
\hline $\mathrm{AMI}$ & 5 & cérebro & 0,074 & 0,012 \\
\hline FDEL-AMII & 5 & cérebro & 0,053 & 0,016 \\
\hline AMI & 15 & cérebro & 0,068 & 0,003 \\
\hline FDEL-AMII & 15 & cérebro & 0,165 & 0,057 \\
\hline AMI & 30 & cérebro & 0,043 & 0,007 \\
\hline FDEL-AMII & 30 & cérebro & 0,146 & 0,054 \\
\hline AMI & 60 & cérebro & 0,048 & 0,008 \\
\hline FDEL-AMII & 60 & cérebro & 0,157 & 0,080 \\
\hline $\mathrm{AMI}$ & 120 & cérebro & 0,032 & 0,005 \\
\hline FDEL-AMII & 120 & cérebro & 0,001 & 0,003 \\
\hline AMI & 300 & cérebro & 0,021 & 0,004 \\
\hline FDEL-AMII & 300 & cérebro & 0,075 & 0,087 \\
\hline AMI & 1440 & cérebro & 0,037 & 0,007 \\
\hline FDEL-AMII & 1440 & cérebro & 0,041 & 0,038 \\
\hline AMI & 2880 & cérebro & 0,029 & 0,004 \\
\hline FDEL-AMII & 2880 & cérebro & 0,124 & 0,119 \\
\hline AMI & 5 & coração & 0,255 & 0,043 \\
\hline FDEL-AMII & 5 & coração & 0,252 & 0,107 \\
\hline AMI & 15 & coração & 0,288 & 0,039 \\
\hline FDEL-AMII & 15 & coração & 0,147 & 0,070 \\
\hline AMI & 30 & coração & 0,153 & 0,015 \\
\hline FDEL-AMII & 30 & coração & 0,292 & 0,139 \\
\hline AMI & 60 & coração & 0,195 & 0,020 \\
\hline FDEL-AMII & 60 & coração & 0,184 & 0,117 \\
\hline AMI & 120 & coração & 0,110 & 0,017 \\
\hline FDEL-AMII & 120 & coração & 0,243 & 0,122 \\
\hline
\end{tabular}




\begin{tabular}{|c|c|c|c|c|}
\hline $\begin{array}{l}\text { AMI } \\
\text { FDEL-AMII }\end{array}$ & $\begin{array}{l}300 \\
300 \\
\end{array}$ & $\begin{array}{l}\text { coração } \\
\text { coração }\end{array}$ & $\begin{array}{l}0,057 \\
0,083\end{array}$ & $\begin{array}{l}0,008 \\
0,105\end{array}$ \\
\hline AMI & 1440 & coração & 0,042 & 0,007 \\
\hline FDEL-AMII & 1440 & coração & 0,255 & 0,094 \\
\hline AMI & 2880 & coração & 0,030 & 0,004 \\
\hline FDEL-AMII & 2880 & coração & 0,034 & 0,034 \\
\hline AMI & 5 & estômago & 2,266 & 0,307 \\
\hline FDEL-AMII & 5 & estômago & 2,185 & 0,708 \\
\hline AMI & 15 & estômago & 1,319 & 0,215 \\
\hline FDEL-AMII & 15 & estômago & 0,979 & 0,248 \\
\hline AMI & 30 & estômago & 0,594 & 0,087 \\
\hline FDEL-AMII & 30 & estômago & 0,953 & 0,261 \\
\hline AMI & 60 & estômago & 1,173 & 0,293 \\
\hline FDEL-AMII & 60 & estômago & 0,669 & 0,235 \\
\hline AMI & 120 & estômago & 1,189 & 0,210 \\
\hline FDEL-AMII & 120 & estômago & 0,364 & 0,070 \\
\hline AMI & 300 & estômago & 0,341 & 0,027 \\
\hline FDEL-AMII & 300 & estômago & 0,641 & 0,263 \\
\hline AMI & 1440 & estômago & 0,234 & 0,045 \\
\hline FDEL-AMII & 1440 & estômago & 0,608 & 0,263 \\
\hline AMI & 2880 & estômago & 0,115 & 0,017 \\
\hline FDEL-AMII & 2880 & estômago & 0,465 & 0,071 \\
\hline AMI & 5 & fígado & 39,272 & 3,766 \\
\hline FDEL-AMII & 5 & fígado & 17,359 & 2,138 \\
\hline AMI & 15 & fígado & 46,102 & 3,143 \\
\hline FDEL-AMII & 15 & fígado & 27,287 & 4,506 \\
\hline AMI & 30 & fígado & 49,113 & 3,532 \\
\hline FDEL-AMII & 30 & fígado & 27,062 & 6,043 \\
\hline AMI & 60 & fígado & 44,849 & 6,186 \\
\hline FDEL-AMII & 60 & fígado & 31,814 & 5,775 \\
\hline AMI & 120 & fígado & 40,854 & 3,734 \\
\hline FDEL-AMII & 120 & fígado & 29,445 & 2,497 \\
\hline AMI & 300 & fígado & 29,180 & 3,574 \\
\hline FDEL-AMII & 300 & fígado & 33,817 & 6,740 \\
\hline AMI & 1440 & fígado & 22,009 & 1,676 \\
\hline FDEL-AMII & 1440 & fígado & 21,736 & 3,775 \\
\hline AMI & 2880 & fígado & 10,926 & 0,932 \\
\hline FDEL-AMII & 2880 & fígado & 18,221 & 2,934 \\
\hline AMI & 5 & int. delgado & 10,792 & 1,848 \\
\hline FDEL-AMII & 5 & int. delgado & 10,410 & 2,053 \\
\hline AMI & 15 & int. delgado & 7,176 & 0,720 \\
\hline FDEL-AMII & 15 & int. delgado & 5,705 & 1,257 \\
\hline AMI & 30 & int. delgado & 6,601 & 0,870 \\
\hline FDEL-AMII & 30 & int. delgado & 4,726 & 0,766 \\
\hline AMI & 60 & int. delgado & 7,567 & 1,080 \\
\hline
\end{tabular}




\begin{tabular}{|c|c|c|c|c|}
\hline FDEL-AMII & 60 & int. delgado & 5,304 & 0,621 \\
\hline AMI & 120 & int. delgado & 6,426 & 0,992 \\
\hline FDEL-AMII & 120 & int. delgado & 3,473 & 0,771 \\
\hline AMI & 300 & int. delgado & 3,302 & 0,489 \\
\hline FDEL-AMII & 300 & int. delgado & 2,447 & 0,297 \\
\hline AMI & 1440 & int. delgado & 1,194 & 0,181 \\
\hline FDEL-AMII & 1440 & int. delgado & 1,190 & 0,231 \\
\hline AMI & 2880 & int. delgado & 0,488 & 0,029 \\
\hline FDEL-AMII & 2880 & int. delgado & 0,837 & 0,168 \\
\hline AMI & 5 & int. grosso & 3,847 & 0,764 \\
\hline FDEL-AMII & 5 & int. grosso & 3,850 & 0,541 \\
\hline AMI & 15 & int. grosso & 2,216 & 0,459 \\
\hline FDEL-AMII & 15 & int. grosso & 1,991 & 0,187 \\
\hline AMI & 30 & int. grosso & 0,978 & 0,190 \\
\hline FDEL-AMII & 30 & int. grosso & 2,055 & 1,745 \\
\hline AMI & 60 & int. grosso & 1,395 & 0,092 \\
\hline FDEL-AMII & 60 & int. grosso & 1,103 & 0,121 \\
\hline AMI & 120 & int. grosso & 4,020 & 0,599 \\
\hline FDEL-AMII & 120 & int. grosso & 1,220 & 0,643 \\
\hline AMI & 300 & int. grosso & 16,472 & 2,013 \\
\hline FDEL-AMII & 300 & int. grosso & 4,336 & 1,106 \\
\hline AMI & 1440 & int. grosso & 1,598 & 0,277 \\
\hline FDEL-AMII & 1440 & int. grosso & 1,846 & 0,609 \\
\hline AMI & 2880 & int. grosso & 0,828 & 0,131 \\
\hline FDEL-AMII & 2880 & int. grosso & 2,059 & 0,412 \\
\hline AMI & 5 & músculo & 10,004 & 1,441 \\
\hline FDEL-AMII & 5 & músculo & 0,896 & 0,186 \\
\hline AMI & 15 & músculo & 8,314 & 1,083 \\
\hline FDEL-AMII & 15 & músculo & 4,019 & 2,315 \\
\hline AMI & 30 & músculo & 7,452 & 1,218 \\
\hline FDEL-AMII & 30 & músculo & 1,458 & 0,461 \\
\hline AMI & 60 & músculo & 6,917 & 0,584 \\
\hline FDEL-AMII & 60 & músculo & 2,147 & 1,879 \\
\hline AMI & 120 & músculo & 4,569 & 0,509 \\
\hline FDEL-AMII & 120 & músculo & 1,159 & 0,061 \\
\hline AMI & 300 & músculo & 3,822 & 0,789 \\
\hline FDEL-AMII & 300 & músculo & 1,671 & 1,037 \\
\hline AMI & 1440 & músculo & 1,741 & 0,201 \\
\hline FDEL-AMII & 1440 & músculo & 0,242 & 0,366 \\
\hline AMI & 2880 & músculo & 1,007 & 0,198 \\
\hline FDEL-AMII & 2880 & músculo & 0,169 & 0,293 \\
\hline AMI & 5 & pulmão & 0,511 & 0,058 \\
\hline FDEL-AMII & 5 & pulmão & 0,706 & 0,223 \\
\hline AMI & 15 & pulmão & 0,581 & 0,065 \\
\hline FDEL-AMII & 15 & pulmão & 0,616 & 0,212 \\
\hline AMI & 30 & pulmão & 0,296 & 0,054 \\
\hline
\end{tabular}




\begin{tabular}{|c|c|c|c|c|}
\hline FDEL-AMII & 30 & pulmão & 0,500 & 0,309 \\
\hline AMI & 60 & pulmão & 0,485 & 0,081 \\
\hline FDEL-AMII & 60 & pulmão & 0,462 & 0,159 \\
\hline AMI & 120 & pulmão & 0,323 & 0,032 \\
\hline FDEL-AMII & 120 & pulmão & 0,322 & 0,084 \\
\hline AMI & 300 & pulmão & 0,120 & 0,019 \\
\hline FDEL-AMII & 300 & pulmão & 0,481 & 0,140 \\
\hline AMI & 1440 & pulmão & 0,078 & 0,008 \\
\hline FDEL-AMII & 1440 & pulmão & 0,085 & 0,007 \\
\hline AMI & 2880 & pulmão & 0,044 & 0,008 \\
\hline FDEL-AMII & 2880 & pulmão & 0,054 & 0,042 \\
\hline AMI & 5 & rins & 1,770 & 0,204 \\
\hline FDEL-AMII & 5 & rins & 2,154 & 0,379 \\
\hline AMI & 15 & rins & 2,180 & 0,473 \\
\hline FDEL-AMII & 15 & rins & 2,756 & 0,805 \\
\hline AMI & 30 & rins & 1,761 & 0,152 \\
\hline FDEL-AMII & 30 & rins & 2,416 & 0,563 \\
\hline AMI & 60 & rins & 1,535 & 0,115 \\
\hline FDEL-AMII & 60 & rins & 2,193 & 0,421 \\
\hline AMI & 120 & rins & 1,118 & 0,107 \\
\hline FDEL-AMII & 120 & rins & 0,918 & 0,205 \\
\hline AMI & 300 & rins & 0,470 & 0,043 \\
\hline FDEL-AMII & 300 & rins & 0,716 & 0,250 \\
\hline AMI & 1440 & rins & 0,235 & 0,048 \\
\hline FDEL-AMII & 1440 & rins & 0,220 & 0,065 \\
\hline AMI & 2880 & rins & 0,149 & 0,022 \\
\hline FDEL-AMII & 2880 & rins & 0,268 & 0,069 \\
\hline AMI & 5 & útero/ovário & 0,974 & 0,123 \\
\hline FDEL-AMII & 5 & útero/ovário & 2,388 & 0,801 \\
\hline AMI & 15 & útero/ovário & 0,569 & 0,094 \\
\hline FDEL-AMII & 15 & útero/ovário & 1,464 & 0,126 \\
\hline AMI & 30 & útero/ovário & 0,220 & 0,032 \\
\hline FDEL-AMII & 30 & útero/ovário & 1,404 & 0,579 \\
\hline AMI & 60 & útero/ovário & 0,262 & 0,060 \\
\hline FDEL-AMII & 60 & útero/ovário & 0,720 & 0,072 \\
\hline AMI & 120 & útero/ovário & 0,209 & 0,030 \\
\hline FDEL-AMII & 120 & útero/ovário & 0,409 & 0,177 \\
\hline AMI & 300 & útero/ovário & 0,122 & 0,017 \\
\hline FDEL-AMII & 300 & útero/ovário & 0,249 & 0,112 \\
\hline AMI & 1440 & útero/ovário & 0,058 & 0,008 \\
\hline FDEL-AMII & 1440 & útero/ovário & 0,335 & 0,194 \\
\hline AMI & 2880 & útero/ovário & 0,046 & 0,007 \\
\hline FDEL-AMII & 2880 & útero/ovário & 0,206 & 0,138 \\
\hline AMI & 5 & sangue & 17,342 & 2,366 \\
\hline FDEL-AMII & 5 & sangue & 6,881 & 0,425 \\
\hline
\end{tabular}




\begin{tabular}{|l|c|l|l|l|}
\hline AMI & 15 & sangue & 15,131 & 1,533 \\
FDEL-AMII & 15 & sangue & 8,271 & 1,272 \\
\hline AMI & 30 & sangue & 8,905 & 0,950 \\
FDEL-AMII & 30 & sangue & 8,431 & 1,976 \\
\hline AMI & 60 & sangue & 7,650 & 0,709 \\
FDEL-AMII & 60 & sangue & 6,634 & 0,857 \\
\hline AMI & 120 & sangue & 4,948 & 0,765 \\
FDEL-AMII & 120 & sangue & 2,942 & 1,202 \\
\hline AMI & 300 & sangue & 1,080 & 0,206 \\
FDEL-AMII & 300 & sangue & 1,199 & 0,439 \\
\hline AMI & 1440 & sangue & 0,601 & 0,086 \\
FDEL-AMII & 1440 & sangue & 0,672 & 0,189 \\
\hline AMI & 2880 & sangue & 0,530 & 0,088 \\
FDEL-AMII & 2880 & sangue & 1,095 & 0,408 \\
\hline
\end{tabular}




\begin{tabular}{|c|c|c|c|c|}
\hline Amostra & Tempo (min) & Órgão & Atividade/g (\%) & D.P. \\
\hline AMI & 5 & baço & 23,079 & 1,244 \\
\hline FDEL-AMI & 5 & baço & 10,580 & 1,562 \\
\hline AMI & 15 & baço & 10,920 & 2,149 \\
\hline FDEL-AMI & 15 & baço & 9,885 & 2,040 \\
\hline AMI & 30 & baço & 11,205 & 2,062 \\
\hline FDEL-AMI & 30 & baço & 12,364 & 2,943 \\
\hline AMI & 60 & baço & 8,627 & 1,268 \\
\hline FDEL-AMI & 60 & baço & 20,959 & 4,641 \\
\hline AMI & 120 & baço & 4,950 & 0,390 \\
\hline FDEL-AMI & 120 & baço & 29,063 & 3,757 \\
\hline AMI & 300 & baço & 1,571 & 0,225 \\
\hline FDEL-AMI & 300 & baço & 54,145 & 5,784 \\
\hline AMI & 1440 & baço & 1,557 & 0,295 \\
\hline FDEL-AMI & 1440 & baço & 27,417 & 5,552 \\
\hline AMI & 2880 & baço & 0,740 & 0,068 \\
\hline FDEL-AMI & 2880 & baço & 20,304 & 6,247 \\
\hline AMI & 5 & cérebro & 0,224 & 0,032 \\
\hline FDEL-AMI & 5 & cérebro & 0,114 & 0,037 \\
\hline AMI & 15 & cérebro & 0,241 & 0,045 \\
\hline FDEL-AMI & 15 & cérebro & 0,526 & 0,146 \\
\hline AMI & 30 & cérebro & 0,120 & 0,019 \\
\hline FDEL-AMI & 30 & cérebro & 0,326 & 0,148 \\
\hline AMI & 60 & cérebro & 0,132 & 0,016 \\
\hline FDEL-AMI & 60 & cérebro & 0,290 & 0,129 \\
\hline AMI & 120 & cérebro & 0,088 & 0,012 \\
\hline FDEL-AMI & 120 & cérebro & 0,003 & 0,006 \\
\hline AMI & 300 & cérebro & 0,050 & 0,010 \\
\hline FDEL-AMI & 300 & cérebro & 0,163 & 0,188 \\
\hline AMI & 1440 & cérebro & 0,078 & 0,012 \\
\hline FDEL-AMI & 1440 & cérebro & 0,155 & 0,062 \\
\hline AMI & 2880 & cérebro & 0,064 & 0,011 \\
\hline FDEL-AMI & 2880 & cérebro & 0,423 & 0,130 \\
\hline AMI & 5 & coração & 5,857 & 2,739 \\
\hline FDEL-AMI & 5 & coração & 2,664 & 0,997 \\
\hline AMI & 15 & coração & 3,780 & 0,698 \\
\hline FDEL-AMI & 15 & coração & 1,510 & 0,635 \\
\hline AMI & 30 & coração & 3,039 & 0,496 \\
\hline FDEL-AMI & 30 & coração & 2,051 & 0,620 \\
\hline AMI & 60 & coração & 2,607 & 0,301 \\
\hline FDEL-AMI & 60 & coração & 1,614 & 1,510 \\
\hline AMI & 120 & coração & 1,973 & 0,250 \\
\hline FDEL-AMI & 120 & coração & 2,142 & 0,337 \\
\hline AMI & 300 & coração & 0,560 & 0,100 \\
\hline
\end{tabular}




\begin{tabular}{|c|c|c|c|c|}
\hline FDEL-AMI & 300 & coração & 1,385 & 1,086 \\
\hline AMI & 1440 & coração & 0,367 & 0,047 \\
\hline FDEL-AMI & 1440 & coração & 2,511 & 0,936 \\
\hline AMI & 2880 & coração & 0,270 & 0,026 \\
\hline FDEL-AMI & 2880 & coração & 0,544 & 0,144 \\
\hline AMI & 5 & estômago & 13,342 & 2,887 \\
\hline FDEL-AMI & 5 & estômago & 8,020 & 1,496 \\
\hline AMI & 15 & estômago & 5,211 & 0,925 \\
\hline FDEL-AMI & 15 & estômago & 5,974 & 2,103 \\
\hline AMI & 30 & estômago & 4,524 & 0,924 \\
\hline FDEL-AMI & 30 & estômago & 5,061 & 1,882 \\
\hline AMI & 60 & estômago & 6,460 & 1,279 \\
\hline FDEL-AMI & 60 & estômago & 2,742 & 0,715 \\
\hline AMI & 120 & estômago & 6,492 & 1,042 \\
\hline FDEL-AMI & 120 & estômago & 1,861 & 0,220 \\
\hline AMI & 300 & estômago & 1,557 & 0,217 \\
\hline FDEL-AMI & 300 & estômago & 3,390 & 1,504 \\
\hline AMI & 1440 & estômago & 0,822 & 0,090 \\
\hline FDEL-AMI & 1440 & estômago & 1,533 & 0,352 \\
\hline AMI & 2880 & estômago & 0,403 & 0,075 \\
\hline FDEL-AMI & 2880 & estômago & 1,870 & 0,452 \\
\hline AMI & 5 & fígado & 54,775 & 6,896 \\
\hline FDEL-AMI & 5 & fígado & 16,324 & 3,336 \\
\hline AMI & 15 & fígado & 57,668 & 6,424 \\
\hline FDEL-AMI & 15 & fígado & 22,337 & 1,242 \\
\hline AMI & 30 & fígado & 60,960 & 5,253 \\
\hline FDEL-AMI & 30 & fígado & 24,016 & 4,334 \\
\hline AMI & 60 & fígado & 56,568 & 6,715 \\
\hline FDEL-AMI & 60 & fígado & 30,190 & 4,935 \\
\hline AMI & 120 & fígado & 51,957 & 6,720 \\
\hline FDEL-AMI & 120 & fígado & 29,361 & 6,682 \\
\hline AMI & 300 & fígado & 26,021 & 3,831 \\
\hline FDEL-AMI & 300 & fígado & 34,436 & 6,011 \\
\hline AMI & 1440 & fígado & 19,102 & 1,430 \\
\hline FDEL-AMI & 1440 & fígado & 18,767 & 4,735 \\
\hline AMI & 2880 & fígado & 10,116 & 1,753 \\
\hline FDEL-AMI & 2880 & fígado & 16,436 & 2,914 \\
\hline AMI & 5 & int. delgado & 9,846 & 1,577 \\
\hline FDEL-AMI & 5 & int. delgado & 8,176 & 1,831 \\
\hline AMI & 15 & int. delgado & 6,881 & 1,172 \\
\hline FDEL-AMI & 15 & int. delgado & 5,027 & 0,995 \\
\hline AMI & 30 & int. delgado & 7,882 & 1,071 \\
\hline FDEL-AMI & 30 & int. delgado & 3,435 & 0,492 \\
\hline AMI & 60 & int. delgado & 7,863 & 0,980 \\
\hline FDEL-AMI & 60 & int. delgado & 3,518 & 0,227 \\
\hline
\end{tabular}




\begin{tabular}{|c|c|c|c|c|}
\hline $\begin{array}{l}\text { AMI } \\
\text { FDEL-AMI }\end{array}$ & $\begin{array}{l}120 \\
120\end{array}$ & $\begin{array}{l}\text { int. delgado } \\
\text { int. delgado }\end{array}$ & $\begin{array}{l}6,614 \\
2,653 \\
\end{array}$ & $\begin{array}{l}0,669 \\
0,482 \\
\end{array}$ \\
\hline AMI & 300 & int. delgado & 3,184 & 0,242 \\
\hline FDEL-AMI & 300 & int. delgado & 1,770 & 0,163 \\
\hline AMI & 1440 & int. delgado & 0,911 & 0,099 \\
\hline FDEL-AMI & 1440 & int. delgado & 0,843 & 0,142 \\
\hline AMI & 2880 & int. delgado & 0,344 & 0,058 \\
\hline FDEL-AMI & 2880 & int. delgado & 0,546 & 0,103 \\
\hline AMI & 5 & int. grosso & 4,734 & 0,244 \\
\hline FDEL-AMI & 5 & int. grosso & 4,552 & 0,879 \\
\hline AMI & 15 & int. grosso & 2,808 & 0,467 \\
\hline FDEL-AMI & 15 & int. grosso & 2,596 & 0,465 \\
\hline AMI & 30 & int. grosso & 1,374 & 0,255 \\
\hline FDEL-AMI & 30 & int. grosso & 2,414 & 1,843 \\
\hline AMI & 60 & int. grosso & 2,039 & 0,398 \\
\hline FDEL-AMI & 60 & int. grosso & 1,236 & 0,090 \\
\hline AMI & 120 & int. grosso & 6,358 & 1,078 \\
\hline FDEL-AMI & 120 & int. grosso & 0,862 & 0,135 \\
\hline AMI & 300 & int. grosso & 14,412 & 1,496 \\
\hline FDEL-AMI & 300 & int. grosso & 4,935 & 0,442 \\
\hline AMI & 1440 & int. grosso & 1,543 & 0,220 \\
\hline FDEL-AMI & 1440 & int. grosso & 1,944 & 0,265 \\
\hline AMI & 2880 & int. grosso & 0,915 & 0,174 \\
\hline FDEL-AMI & 2880 & int. grosso & 1,850 & 0,359 \\
\hline AMI & 5 & músculo & 1,191 & 0,172 \\
\hline FDEL-AMI & 5 & músculo & 0,112 & 0,023 \\
\hline AMI & 15 & músculo & 0,990 & 0,129 \\
\hline FDEL-AMI & 15 & músculo & 1,334 & 0,805 \\
\hline AMI & 30 & músculo & 0,887 & 0,145 \\
\hline FDEL-AMI & 30 & músculo & 0,182 & 0,058 \\
\hline AMI & 60 & músculo & 0,823 & 0,070 \\
\hline FDEL-AMI & 60 & músculo & 0,157 & 0,092 \\
\hline AMI & 120 & músculo & 0,544 & 0,061 \\
\hline FDEL-AMI & 120 & músculo & 0,128 & 0,035 \\
\hline AMI & 300 & músculo & 0,455 & 0,094 \\
\hline FDEL-AMI & 300 & músculo & 0,209 & 0,130 \\
\hline AMI & 1440 & músculo & 0,220 & 0,036 \\
\hline FDEL-AMI & 1440 & músculo & 0,030 & 0,046 \\
\hline AMI & 2880 & músculo & 0,152 & 0,040 \\
\hline FDEL-AMI & 2880 & músculo & 0,162 & 0,194 \\
\hline AMI & 5 & pulmão & 5,408 & 0,886 \\
\hline FDEL-AMI & 5 & pulmão & 3,478 & 0,983 \\
\hline AMI & 15 & pulmão & 3,509 & 0,569 \\
\hline FDEL-AMI & 15 & pulmão & 3,860 & 1,570 \\
\hline AMI & 30 & pulmão & 2,040 & 0,148 \\
\hline
\end{tabular}




\begin{tabular}{|c|c|c|c|c|}
\hline FDEL-AMI & 30 & pulmão & 2,203 & 0,316 \\
\hline AMI & 60 & pulmão & 2,513 & 0,381 \\
\hline FDEL-AMI & 60 & pulmão & 2,354 & 0,739 \\
\hline AMI & 120 & pulmão & 1,478 & 0,259 \\
\hline FDEL-AMI & 120 & pulmão & 1,825 & 0,403 \\
\hline AMI & 300 & pulmão & 0,526 & 0,068 \\
\hline FDEL-AMI & 300 & pulmão & 2,861 & 0,390 \\
\hline AMI & 1440 & pulmão & 0,330 & 0,056 \\
\hline FDEL-AMI & 1440 & pulmão & 0,401 & 0,034 \\
\hline AMI & 2880 & pulmão & 0,211 & 0,037 \\
\hline FDEL-AMI & 2880 & pulmão & 0,374 & 0,188 \\
\hline AMI & 5 & rins & 10,677 & 2,659 \\
\hline FDEL-AMI & 5 & rins & 8,076 & 1,868 \\
\hline AMI & 15 & rins & 9,887 & 1,739 \\
\hline FDEL-AMI & 15 & rins & 9,443 & 0,789 \\
\hline AMI & 30 & rins & 8,440 & 0,775 \\
\hline FDEL-AMI & 30 & rins & 7,960 & 1,445 \\
\hline AMI & 60 & rins & 6,744 & 0,647 \\
\hline FDEL-AMI & 60 & rins & 6,826 & 1,742 \\
\hline AMI & 120 & rins & 5,033 & 0,794 \\
\hline FDEL-AMI & 120 & rins & 3,255 & 0,852 \\
\hline AMI & 300 & rins & 1,557 & 0,210 \\
\hline FDEL-AMI & 300 & rins & 2,682 & 0,656 \\
\hline AMI & 1440 & rins & 0,753 & 0,059 \\
\hline FDEL-AMI & 1440 & rins & 1,319 & 0,883 \\
\hline AMI & 2880 & rins & 0,456 & 0,072 \\
\hline FDEL-AMI & 2880 & rins & 0,792 & 0,075 \\
\hline AMI & 5 & sangue & 11,797 & 1,610 \\
\hline FDEL-AMI & 5 & sangue & 4,915 & 0,304 \\
\hline AMI & 15 & sangue & 10,293 & 1,043 \\
\hline FDEL-AMI & 15 & sangue & 5,908 & 0,908 \\
\hline AMI & 30 & sangue & 6,327 & 0,877 \\
\hline FDEL-AMI & 30 & sangue & 6,022 & 1,412 \\
\hline AMI & 60 & sangue & 5,204 & 0,482 \\
\hline FDEL-AMI & 60 & sangue & 4,739 & 0,612 \\
\hline AMI & 120 & sangue & 3,366 & 0,520 \\
\hline FDEL-AMI & 120 & sangue & 2,101 & 0,859 \\
\hline AMI & 300 & sangue & 0,735 & 0,140 \\
\hline FDEL-AMI & 300 & sangue & 0,856 & 0,314 \\
\hline AMI & 1440 & sangue & 0,409 & 0,059 \\
\hline FDEL-AMI & 1440 & sangue & 0,480 & 0,135 \\
\hline AMI & 2880 & sangue & 0,361 & 0,060 \\
\hline FDEL-AMI & 2880 & sangue & 0,782 & 0,291 \\
\hline AMI & 5 & útero/ovário & 15,199 & 2,848 \\
\hline FDEL-AMI & 5 & útero/ovário & 10,531 & 2,517 \\
\hline
\end{tabular}




\begin{tabular}{|l|c|l|l|l|}
\hline AMI & 15 & útero/ovário & 4,402 & 0,855 \\
FDEL-AMI & 15 & útero/ovário & 6,154 & 1,605 \\
\hline AMI & 30 & útero/ovário & 4,401 & 0,614 \\
FDEL-AMI & 30 & útero/ovário & 3,430 & 1,203 \\
\hline AMI & 60 & útero/ovário & 2,703 & 0,594 \\
FDEL-AMI & 60 & útero/ovário & 3,946 & 1,662 \\
\hline AMI & 120 & útero/ovário & 2,013 & 0,189 \\
FDEL-AMI & 120 & útero/ovário & 1,403 & 0,710 \\
\hline AMI & 300 & útero/ovário & 1,315 & 0,236 \\
FDEL-AMI & 300 & útero/ovário & 0,889 & 0,225 \\
\hline AMI & 1440 & útero/ovário & 0,693 & 0,047 \\
FDEL-AMI & 1440 & útero/ovário & 0,732 & 0,311 \\
\hline AMI & 2880 & útero/ovário & 0,214 & 0,030 \\
FDEL-AMI & 2880 & útero/ovário & 0,578 & 0,462 \\
\hline
\end{tabular}




\section{REFERÊNCIAS BIBLIOGRÁFICAS}

AHSANA, F.; RIVASB, I. P.; KHANA, M. A.; SUAREZ, A. I. T. Targeting to macrophages: role of physicochemical properties of particulate carriers-liposomes and microspheres - on the phagocytosis by macrophages. J. Control. Release, v.79, p. 29-40, 2002.

AL JASSER, M.; EL-YAZIGI, A.; KOJAN, M.; CROFT, S.L. Skin uptake, distribution and elimination of antimony following administration of sodium stibogluconate to patients with cutaneous leishmaniasis. Antimicrob. Agents. Chemother., v.39, p.516$519,1995$.

ALVING, C. R.; STECK, E. A.; CHAPMAN, W. L. JR.; WAITS, V. B.; HENDRICKS, L. D.; SWARTZ, G. M. JR.; HANSON. W. L. Therapy of leishmaniasis: superior efficacies of liposome-encapsulated drugs. Proc. Natl. Acad. Sci., v.75, p. 29592963, 1978 a.

ALVING, C. R.; STECK, E. A.; HANSON, W. L.; LOIZEAUX, P.S.; CHAPMAN, W. L. JR.;. WAITS, V. B. Improved therapy of experimental leishmaniasis by use of a liposome-encapsulated antimonial drugs. Life Sci., v.22, p. 1021-1026, 1978 b.

ALVING, C. R.; STECK, E. A.; CHAPMAN, W. L. JR.; WAITS, V. B.; HENDRICKS, L. D.; SWARTZ, G. M. JR.; HANSON, W. L. Liposomes in leishmaniasis: therapeutic of antimonial drugs, 8-aminoquinolines and tetracycline. Life Sci., v. 26, p. 2231$2238,1980$.

ALVING, C. R.; SWARTZ, G. M. JR.; HENDRICKS, L. D.; CHAPMAN, W. L. JR.; WAITS, V. B.; HANSON, W. L. Liposomes in leishmaniasis: effects of parasite virulence on treatment of experimental leishmaniasis in hamsters. Ann. Trop. Med. Parasitol., v. 78, p. 279-286, 1984.

ANDERSON, M.; OMRI, A. The effect of different lipid components on the in vitro stability and release kinetics of liposome formulations. Drug Delivery, v.11, p. 3339, 2004.

ANVISA (AGÊNCIA NACIONAL DE VIGILÂNCIA SANITÁRIA). RESOLUÇÃORDC Nº4, DE 18 DE DEZEMBRO DE 2009.

AUSBORN, M.; SCHREIER, H.; BREZESINSKI, G.; FABIAN, H.; MEYER, H. W.; NUHN, P. The protective effect of free and membrane-bound cryoprotectants during freezing and freeze-drying of liposomes. J. Control Release, v. 30, p. 105-116, 1994.

BAILLIE, A. J.; DOLAN, T. F.; ALEXANDER, J.; CARTER, K. C. Visceral leishmaniasis in the BALB/c mouse: sodium stibogluconate treatment during acute and chronic stages of infection. Int. J. Pharm., v.57, p.23-28, 1989. 
BALAÑA-FOUCE, R.; REGUERA, R. M.; CUBRÍA, J. C.; ORDÓÑEZ, D. The pharmacology of leishmaniasis. Gen. Pharmac., v.30, p. 435-443, 1998.

BANERJEE, A. Liposomes: applications in medicine. J Biomater Appl., v. 16, p. 3-21, 2001.

BANGHAM, A. D; STANDISH, M. M.; WATKINS, J. C. Diffusion of univalent ions across the lamellae of swollen phospholipids. J. Mol. Biol., v.13, p.238-52, 1965.

BAO, A.; GOINS, B.; KLIPPER, R.; NEGRET, G.;MAHINDARATNE, M.; PHILLIPS, W.T. A novel liposome radiolabeling method using ${ }^{99 m}$ Tc-"SNS/S" complexes: in vitro and in vivo evaluation. J. Pharmac. Sci., v.92, p.1893-1904, 2003.

BERMAN, J. D.; WADDELL, D.; HANSON, B. D. Biochemical mechanisms of the antileishmanial activity of sodium stibogluconate. Antimicrob. Agents Chemother., v. 27, p. 916-920, 1985.

BERMAN, J.; ALVING, C.; HANSON, W.; CHAPMAN, W.; LOPEZ-BERESTEIN, G. Antileishmanial activity of liposome-encapsulated amphotericin B in hamster and monkeys. Antimicrob. Agents Chemother., v. 30, p. 847-51, 1986.

BERMAN, J. D.; GALLALEE, J. F.; HANSEN, B. D. Leishmania mexicana: uptake of sodium stibogluconate (Pentostam) and pentamidine by parasite and macrophages. Exp. Parasitol., v.64, p. 127-131, 1987.

BERMAN, J. D.; GROGL, M. Leishmania mexicana: chemistry and biochemistry of sodium stibogluconate (Pentostam). Exp. Parasitol., v.67, p. 96-103, 1988.

BERMAN, J. D. Human leishmaniasis: clinical, diagnostic and chemotherapeutic developments in the last 10 years. Clin. Infect. Dis., v.24, p.684-703, 1997.

BLACK, C. D.; WATSON, G. J.; WARD, R. J. The use of Pentostam liposomes in the chemotherapy of experimental leishmaniasis. Trans. R. Soc. Trop. Med. Hyg. v.71, p.550-552, 1977.

BORBOREMA, S. E. T.; ANDRADE, H. F. JR.; OSSO, J. A. JR.; NASCIMENTO, N. In vitro antileishmanial properties of neutron-irradiated meglumine antimoniate. Braz Arch. Biol. Techn., v. 48, p. 6367, 2005 a.

BORBOREMA, S. E. T. Biodistribuição do antimoniato de meglumina em animais sadios e infectados com Leishmania (L.) chagasi. 2005. Dissertação (Mestrado). Instituto de Pesquisas Energéticas e Nucleares, São Paulo. 
BORBOREMA, S. E. T.; ANDRADE JR, H. F. DE; OLIVEIRA, A.; MURAMOTO, E.; OSSO JR, J. A.; NASCIMENTO, N. DO. Production of neutron-irradiated meglumine antimoniate and its biodistribution in healthy and Leishmania (L.) chagasi infected mice. In: 2005 International Nuclear Atlantic Conference, 28/0802/09, 2005, Santos, SP, Brasil, b.

BORBOREMA, S. E. T.; ANDRADE, H. F. JR.; OSSO, J. A. JR.; NASCIMENTO, N. Tissue distribution of radiolabeled phosphatidylserine-containing liposome in mice. In: 2009 International Nuclear Atlantic Conference, 27/09- 02/10, 2009 Rio de Janeiro, RJ, Brasil.

BRADY, F. J.; LAWTON, A. H.; COWIE, D. B.; ANDREWS, H. L.; NESS, A. T.; OGDEN, G. E. Localization of trivalent radioactive antimony following intravenous administration to dogs infected with Dirofilaria immitis. Am. J. Trop. Med., v. 25, p. 103-107, 1945.

BBRASIL. SVS/MS. MINISTÉRIO DA SAÚDE. SECRETARIA DE VIGILÂNCIA EM SAÚDE. DEPARTAMENTO DE VIGILÂNCIA EPIDEMIOLÓGICA. Manual de vigilância e controle da leishmaniose visceral. Brasília: Editora do Ministério da Saúde, 2006 (Série A. Normas e Manuais Técnicos).

BRASIL. SVS/MS MINISTÉRIO DA SAÚDE. SECRETARIA DE VIGILÂNCIA EM SAÚDE. Manual de vigilância da leishmaniose tegumentar americana. 2. ed. atual. Brasília: Editora do Ministério da Saúde, 2007 (Serie A. Normas e Manuais Técnicos).

BRASIL. SVS/MS. MINISTÉRIO DA SAÚDE. SECRETARIA DE VIGILÂNCIA EM SAÚDE guia de vigilância epidemiológica - Caderno 11. Brasília: Editora do Ministério da Saúde, 2009. (Série A. Normas e Manuais Técnicos).

BRIONES, E.; COLINO, C. I.; LANAO, J. M. Delivery systems to increase the selectivity of antibiotics in phagocytic cells. J. Control.Release, v. 125, p. 210-227, 2008.

BRITO, C.; RAVEL, C.; BASTIEN, P.; BLAINEAU, C.; PAGÉS, M.; DEDET, J. P.; WINCKER, P. Conserved linkage groups associated with large-scale chromosomal rearrangements between Old World and New World Leishmania genomes. Gene, v.222, p. 107-117, 1998.

BROWNELL, G. L.; BERMAN, M.; ROBERTSON, J. S. Nomenclature for tracer kinetics. Int. J. Appl. Radiat. Isto., v.19, p.249-262, 1968.

CARTER, K. C.; BAILLIE, A. J.; ALEXANDER, J.; DOLAN, T. F. The therapeutic effect of sodium stibogluconate in BALB/c mice infected with Leishmania donovani is organ-dependent. J. Pharm. Pharmacol., v.40, p.370-373, 1988. 
CARTER, K. C.; DOLAN, T. F.; ALEXANDER, J.; BAILLIE, A. J.; MCCOLGAN, C. Visceral leishmaniasis: drug carrier characteristics and the ability to clear parasites from the liver, spleen and bone marrow in Leishmania donovani infected BALB/c mice. J. Pharm. Pharmacol., v. 41, p. 87-91, 1989.

CVE. CENTRO DE VIGILANCIA EPIDEMIOLÓGICA. Disponível em: <http://www.cve.saude.sp.gov.br> Acessado em 10/01/2010.

CHAPMAN, W. L.; HANSON, W. L.; ALVING, C. R.; HENDRICKS, L. D. Antileishmanial activity of liposome-encapsulated meglumine antimonate in the dog. Am. J. Vet. Res., v. 45, p. 1028-30, 1984.

CHAPPUIS, F.; SUNDAR, S.; HAILU, A.; GHALIB, H.; RIJAL, S.; PEELING, R. W.; ALVAR, J.; BOELAERT, M. Visceral leishmaniasis: what are the needs for diagnosis, treatment and control? Nat. Rev. Microbiol., v. 5, p. S7-16, 2007.

CHETANACHAN, P.; AKARACHALANON, P.; WORAIRUNWONG, D.; DARARUTANA, P.; BANGTRAKULNONTH, A.; BUNJOP, M.; KONGMUANG, S. Ultrastructural characterization of liposomes using transmission electron microscope. Adv. Mat. Res., v. 55-57, p. 709-711, 2008.

CHIRAC, P.; TORREELE, E. Global framework on essential health R\&D. Lancet, v. 367, p. $1560-1561,2006$

CHULAY, J. D.; FLECKENSTEIN, L.; SMITH, D. H. Pharmacokinetics of antimony during treatment of visceral leishmaniasis with sodium stibogluconate or meglumine antimoniate. Trans. R. Soc. Trop. Med. Hyg., v.82, p.69-72, 1988.

COHN, C. A.; PAK, A.; STRONGIN, D.; SCHOONEN, M. A. Quantifying hydrogen peroxide in iron-containing solutions using leucocrystal violet. Geochem. Trans., v.6, p. 47-51, 2005.

COLLINS, M.; CARTER, K. C.; BAILLIE, A. J. Visceral leishmaniasis in the BALB/c mouse: antimony tissue disposition and parasite suppression after the administration of free stibogluconate. Ann. Trop. Med. Parasitol., v.86, p.35-40, 1992.

CNEN. COMISSÃO NACIONAL DE ENERGIA NUCLEAR. Disponível em: $<$ http://www.cnen.gov.br >. Acesso em: 09/01/2010.

COWIE, D. B.; LAWTON, A. H.; NESS, A. T.; BRADY, F. J.; OGDEN, G. E. Localization of radioactive antimony following multiple daily injections to a dog infected with Dirofilaria immitis. J. Washington Acad. Sci.,, v. 35, p. 192-196, 1945. 
CROFT, S. L.; COOMBS, G. H. Leishmaniasis - current chemotherapy and recent advances in the search for novel drugs. Trends Parasitol., v.19, p.502-508, 2003.

DAVIES, C. R.; KAYE, P.; CROFT, S. L.; SUNDAR, S. Leishmaniasis: new approaches to disease control. BMJ, v.326, p.377-382, 2003.

DENTON, H.; MCGREGOR, J. C.; COOMBS, G. H. Reduction of pentavalent antimonial drugs by a parasite-specific thiol dependent antileishmanial reductase TDR1.

Biochem. J., v.1, p.405-12, 2004.

DEMICHELI, C.; FRÉZARD, F.; LECOUVEY, M.; GARNIER-SUILLEROT, A. Antimony $(\mathrm{V})$ complex formation with adenine nucleosides in aqueous solution. Biochim. Biophys. Acta, v. 1570, p. 192-8, 2002.

DESJEUX, P. Leishmaniasis, public health aspects and control. Clin. Dermatol., v. 14, p.417-423, 1996.

DOREA, J. G.; COSTA, J. M. L.; HOLZBECHER, J.; RYAN, D. E.; MARSDEN, P. D. Antimony accumulation in hair during treatment of leishmaniasis. Clin. Chem., v. 33, p. 2081-2082, 1987.

DOREA, J. G.; MERCHN-HAMANN, E.; RYAN, D. E.; HOLZBECHER, J. Retention of antimony in hair during leishmaniasis treatment. Clin. Chim. Acta, v. 179, p. 341346, 1989.

DOREA, J. G.; MERCHN-HAMANN, E.; RYAN, D. E.; HOLZBECHER, J. Retention of antimony in skin biopsies of leishmaniasis patients after treatment with nmethylglucamine antimoniate. Clin. Chem., v. 36, p. 680-682, 1990.

DORETTO, K. M. Síntese e caracterização do antimoniato de meglumina usado no tratamento de leishmaniose e desenvolvimento de métodos para especiação de antimônio. 2008. Dissertação (Mestrado) - Universidade Estadual de Campinas, São Paulo.

DNDI. DRUGS FOR NEGLETED DISEASES INITIATIVE - INICIATIVA MEDICAMENTOS PARA DOENÇAS NEGLIGENCIADAS. Disponível em: < http://www.dndi.org.br>. Acessado em Acessado em 10/01/2010.

EPHROS, M.; BITNUN, A.; SHAKED, P.; WALDMAN, E.; ZILBERSTEIN, D. Stagespecific activity of pentavalent antimony against Leishmania donovani axenic amastigotes. Antimicrob. Agents Chemother., v. 43, p. 278-282, 1999. 
FERREIRA, C. S.; MARTINS, P. S.; DEMICHELI, C.; BROCHU, C.; OUELLETTE, M.; FREZARD, F. Thiol-induced reduction of antimony (V) into antimony(III): a comparative study with trypanothione, cysteinyl-glycine, cysteine and glutathione. Biometals, v.16, p. 441-446, 2003.

FERREIRA, C. F.; PIMENTA, A. M. C.; DEMICHELI, C.; FREZARD, F. Characterization of reactions of antimoniate and meglumine antimoniate with a guanine ribonucleoside at different pH. BioMetals, v.19, p. 573-581, 2006.

FIDLER, I. J. Targeting of immunomodulators to mononuclear phagocytes for Therapy of cancer. Adv. Drug Deliv. Rev., v. 2, p. 69-106, 1988.

FLORIO, J.C. Absorção, distribuição, biotransformação e eliminação. In.: SPINOSA, H. DE S.; GORNIAK, S.Z.; BERNARDI, M.M. Farmacologia Aplicada a Medicina Veterinária. 3.ed. Rio de Janeiro, RJ.: Guanabara Koogan, 2002.

FRANCO, M.A.; BARBOSA, A.C.; RATH, S.; DOREA, J.G. Antimony oxidation states in antileishmanial drugs. Am. J. Trop. Méd. Hyg., v.52, p.435-437, 1995.

FRÉZARD, F. Liposomes: from biophysics tothe design of peptide vaccines. Braz. J. Med. Biol. Res., v. 32, p. 181-189, 1999.

FRÉZARD, F.; MICHALICK, M. S. M.; SOARES, C. F.; DEMICHELI, C. Novel methods for the encapsulation of meglumine antimoniate into liposomes. Braz J Med Biol. Res., v. 33, p. 841-846, 2000.

FRÉZARD, F.; DEMICHELI, C.; FERREIRA, C.S.; COSTA, M.A. Glutathione-induced conversion of pentavalent antimony to trivalent antimony in meglumine antimoniate. Antimicrob. Agents Chemother., v.45, p.913-916, 2001.

FRÉZARD, F.; SCHETTINI, D. A.; ROCHA, O. G. F.; DEMICHELI, C. Lipossomas: propriedades físico-químicas e farmacológicas, aplicações na quimioterapia à base de antimônio. Quim. Nova, v.28, p. 511-518, 2005.

FRÉZARD, F.; DEMICHELI, C.; RIBEIRO, R. R. Pentavalent antimonials: new perspectives for old drugs. Molecules, v. 14, p. 2317-2336, 2009.

FUSAI, T.; DURAND, R.; BOULARD, Y.; PAUL, M.; BORIES, C.; RIVOLLET, D.; HOUIN, R.; DENIAU, M. Importance des medicaments vectorises dans le traitement de la leishmaniose viscerale. Med. Trop., v. 55, p.73-79, 1995.

FUSAI, T.; DURAND, R.; BOULARD, Y.; PAUL, M.; BORIES, C.; RIVOLLET, D.; ASTIER, A.; HOUIN, R.; DENIAU, M. Ultrastructural changes in parasites induced by nanoparticle-bound pentamidine in a Leishmania major mouse model. Parasite., v.2, p.133-139, 1997. 
GELLHORN, A.;VAN DYKE, H. B. The correlation between distribution of antimony in tissues and chemotherapeutic effect in experimental leishmaniasis. J. Pharmacol. Exp. Ther., v. 88, p.162-172, 1946.

GILBREATH, M. J.; NACY, C. A.; HOOVER, D. L.; ALVING, C. R.; SWARTZ, G. M. JR.; MELTZER, M. S. Macrophage activation for microbicidal activity against Leishmania major: inhibition of lymphokine activation by phosphatidylcholinephosphatidylserine liposomes. J. Immunol., v. 134, p. 3420-3425, 1985.

GILBREATH, M. J.; HOOVER, D. L.; ALVING, C. R.; SWARTZ, G. M. JR.; MELTZER, M. S. Inhibition of lymphokine-induced macrophage microbicidal activity against Leishmania major by liposomes: Characterization of the physicochemical requirements for liposome inhibition. J. Immunol., v. 137, p. 16811687, 1986.

GLAVAS-DODOV, A. M.; FREDRO-KUMBARADZI, E.; GORACINOVA, K.; SIMONOSKA, M.; CALIS, S.; TRAJKOVIC-JOLEVSKA, S.; HINCAL, A. A. The effects of lyophilization on the stability of liposomes containing 5-FU. Int. J. Pharm., v. 291, p. 79-86, 2005.

GOODWIN, L. G.; PAGE, J. E. A study of the excretion of organic antimonials using a polarographic procedure. Biochem. Jour., v.37, p.198-209, 1943.

GROTTI, M.; FRANCHE, R. Reduction of acid effects in inductively coupled plasma optical emission spectrometry using internal standards selectes by principal component analysis. J. Anal. At. Spectrom., v.18, p. 1192-1197, 2003.

GUERIN, P. J.; OLLIARO, P.; SUNDAR, S.; BOELAERT, M.; CROFT, S. L.; DESJEUX, P.; WASUNNA, M. K.; BRYCESON, A. D. Visceral leishmaniasis: current status of control, diagnosis, and treatment, and a proposed research and development agenda. Lancet Infect. Dis., v.2, p.494-501, 2002.

HEATH, S.; CHANCE, M. L.; NEW, R. R. C. Quantitative and ultrastructural studies on the uptake of drug loaded liposomes by mononuclear phagocytes infected with Leishmania donovani. Mol. Biochem. Parasitol., v. 12, p.49-60, 1984.

HEPBURn, N. C. Cutaneous leishmaniasis: an overview. J. Postgrad. Méd.,v. 49, p.50-4, 2003.

HERWALDT, B. L. Leishmaniasis. Lancet. , v.354, p.1191-99, 1999.

HUNTER, C. A.; DOLAN, T. F.; COOMBS, G. H.; BAILlIE, A. J. Vesicular systems (niosomes and liposomes) for delivery of sodium stibogluconate in experimental murine visceral leishmaniasis. J.Pharm.Pharmacol., v.40, p.161-165, 1988. 
IPEN. INSTITUTO DE PESQUISAS ENERGÉTICAS E NUCLEARES. Disponível em: < http://www.ipen.br>. Acessado em Acessado em 10/01/2010.

JAAFARI, M. R.; BAVARSAD, N.; BAZZAZ, B. S. F.; SAMIEI, A.;SOROUSH, D.; GHORBANI, S.; HERAVI, M. M. L.; KHAMESIPOU, A. Effect of topical liposomes containing paromomycin sulfate in the course of Leishmania major infection in susceptible Balb/c mice. Antimicrob. Agents Chemother., v. 53, p. 2259-2265, 2009.

JOUSMA, H.; TALSMA, H.; SPIES, F.; JOOSTEN, J.G.H.; JUNGINGER, H.E.; CROMMELIN, D.J.A. Characterization of liposomes. The influence of extrusion of multilamellar vesicles through polycarbonate membranes on particle size, particle size distribution and number of bilayers. Int. J. Pharm., v.35, p .263-214, 1987.

KAMPS, J. A. A. M.; SCHERPHOF, G. L. Biodistribution and uptake of liposomes in vivo. Meth. Enzymol., v. 387, p. 257-266, 2004.

KIMA, P. E. The amastigote forms of Leishmania are experts at exploiting host cell processes to establish infection and persist. Int. J. Parasitol., v. 37, p. 1087-1096, 2007.

KOO, O. M.; RUBISTEIN, I.; ONYUSKSEL, H. Role of nanotechnology in targeted drug delivery and imaging: a concise review. Nanomedicine, p. 193-212, 2005.

KRACHLER, M.; BUROW, M.; EMONS, H. Development and evaluation of an analytical procedure for the determination of antimony in plant materials by hydride generation atomic absorption spectrometry. Analyst, v. 124, p. 777-782, 1999 a.

KRACHLER, M.; BUROW, M.; EMONS, H. Optimized procedure for the determination in lipid-rich environmental matrices by flow injection hydride generation atomic absorption spectrometry. Analyst, v. 124, p. 923-926, 1999 b.

LINDOSO, J. A. L.; LINDOSO, A. A. B. P. Neglected tropical diseases in Brazil. Rev. Inst. Med. trop. S. Paulo, v. 51, p. 247-253, 2009.

LOPEZ-BERESTEIN, G. Liposomes as Carriers of Antimicrobial Agents. Antimicrob. Agents Chemother., p. 675-678,1987.

LUGO DE YARBUH, A.; PETIT DE PEÑA, Y.; BURGUERA, J. L.; BURGUERA, M. Antimony determination in tissues and serum of hamster infects with Leishmania garnhami and treated with meglumine antimoniate. Ann. Trop. Med. Parasitol., v.88, p.37-41, 1994.

MAGILL, A. J. Leishmaniasis. In: STICKLAND, G. T. Hunter's Tropical Medicine and Emergins Infections Diseases. 8. ed., 2000. 
MARSDEN, P. D.; NONATA, R. R. Mucocutaneous Leishmaniasis - A review of clinical aspects. Rev. Soc. Bras. Med. Trop., v.9, p. 309-326, 1975.

MARSDEN, P. D. Pentavalent antimonials: old drug for news diseases. Rev. Soc. Bras. Med. Trop., v.18, p.187-198, 1985.

MARTY, C.; MEYLAN, C.; SCHOTT, H.; BALLMER-HOFER, K.; SCHWENDENER, R. A. Enhanced heparan sulfate proteoglycan-mediated uptake of cell-penetrating peptide-modified liposome. Cell. Mol. Life Sci., v.61, p. 1785-1794, 2004.

MAYER, L. D.; BALLY, M. B.; HOPE, M. J.; CULLIS, P. R. Techniques for encapsulating bioactive agents into liposomes. Chem. Phys. Lipids, v. 40, p. 333$345,1986$.

MEIKLE S. R.; EBERL, S.; IIDA, H. Instrumentation and methodology for quantitative pre-clinical imaging studies. Curr. Pharm. Des.,v. 7, p. 1945-66, 2001.

MEYERHOFF, A. U.S. Food and Drug Administration approval of Ambisome (lipossomal amphotericin B) for treatment of visceral leishmaniasis. C.I.D., v.28, p. 42-8, 1999.

MIEKELEY, N.; MORTARI, S. R.; SCHUBACH, A. O. Monitoring of total antimony and its species by ICP-MS and on-line ion chromatography in biological samples from patients treated for leishmaniasis. Anal. Bioanal. Chem., v. 372, p. 495-502, 2002.

MISHA, M.; BISWAS, U. K.; JHA, A. M.; KHAN, A. B. Amphotericin versus stibogluconate in first line treatment of Indian Kala- Azar. Lancet., v.344, p.15991600, 1994.

MURRAY, H. W, BERMAN J. D, DAVIES, C. R E SARAVIA, N. G. Advances in leishmaniasis. Lancet, v. 366, p.1561-77, 2005.

NAN, A.; CROFT, S. L.; YARDLEY, V.; GHANDEHARI, H. Targetable water-soluble polymer-drug conjugates for the treatment of visceral leishmaniasis. J. Control. Release, v.94, p. 115- 127, 2004.

NADERER, T.; MCCONVILLE, M. J. The Leishmania-macrophage interaction: a metabolic perspective. Cell. Microbiol., v. 10, p. 301-308, 2008.

NEVES, M.; KLING, A.; LAMBRECHT, R. M. Radionuclide production for therapeutic radiopharmaceuticals. Appl. Radiat. Isot., v.57, p.657-664, 2002.

NEW, R. R. C.; CHANCE, M. L.; THOMAS, S. C.; PETERS, W. Antileishmanial activity of antimonials entrapped in liposomes. Nature, v. 272, p. 55-6, 1978. 
OLIVEIRA, F. B. DE; SHETTINI, A.; FERREIRA, C. S.; TATES, B.; ROCHA, O. G. F.; FREZARD, F.; DEMICHELI, C. Kinetics of antimony(v) reduction by l-cysteine pharmacological implications and application to the determination of antimony in pentavalent antimonial drugs. J. Braz. Chem. Soc., v. 17, p. 1642-1650, 2006.

OLSON, F.; HUNT, C.; SZOKA, F. C.; VAIL, W. J.; PAPAHADJOPOULOS, D. Preparation of liposomes of defined size distribution by extrusion through polycarbonate membranes. Biochim. Biophys. Acta, v. 557, p. 9-23, 1979.

OMS. ORGANIZAÇÃO MUNDIAL DE SÁUDE - WORLD HEALTH ORGANIZATION (WHO). Disponível em: < http://www.who.int/leishmaniasis/en/> . Acessado em Acessado em 10/01/2010.

OSSO JR., J. A.; SUZIKI, K. N.; COSTA, R. F.; BARRIO, G.; BRAMBILLA, T. P.; LOPES, P. C.; BORBOREMA, S. E. T.; DIAS, C. R. B. R.; LIMA, A. L. P. V.; GASIGLIA, H. T.; CORREIA, J. L.; VILLELA, L. A.; SILVA, N. C.; BEZERRA, R. R. L.; LIMA, R. F.; BARBOZA, M. R. F. F.; MENGATTI, J. Radioisotope production for nuclear medicine using the IEA-R1M reactor at IPEN-CNEN/SPBrazil. In: 13th INTERNATIONAL TOPICAL MEETING ON RESEARCH REACTOR FUEL MANAGEMENT, 22-25 março, 2009, Vienna, Austria. Transactions RRFM 2009, p. 247-251, 2009.

OTTO, G. F.; MAREN, T. H.; BROWN, H. W. Blood levels and excretion rates of antimony in persons receiving trivalent and pentavalent antimonials. $\boldsymbol{A}$. J. H., v.46, p.193-211, 1947.

OTTO, G. F.; MAREN, T. H. VI. Studies on the excretion and concentration of antimony in blood and other tissues following the injection of trivalent and pentavalent antimonials into experimental animals. Am. J. Hyg., v.51, p.370-385, 1950.

OUELLETTE, M.; DRUMMELSMITH, J.; PAPADOPOULOU, B. Leishmaniasis: drugs in the clinic, resistance and new developments. Drug Resist. Updat. v.7, p.257-266, 2004.

OLIVEIRA, F. B. DE; SCHETTINI, D. A., FERREIRA, C. S.; RATES, B.; ROCHA, O. G. F.; FREZARD, F.; DEMICHELI,C. Kinetics of antimony (V) reduction by 1cysteine. Pharmacological implications and application to the determination of antimony in pentavalent antimonial drugs. J. Braz.Chem. Soc. v.17, p.1642-1650, 2006.

PAL, S.; RAVINDRAN, R.; ALI, N. Combination Therapy Using Sodium Antimony Gluconate in Stearylamine-Bearing Liposomes against Established and Chronic Leishmania donovani Infection in BALB/c Mice. Antimicrob. Agents Chemother., v. 48, p. 3591-3593, 2004. 
PAMPLIN, C.L.; DESJARDINS, R.; CHULAY, J.D.; TRAMONT, E.; HENDRICKS, L.; CANFIELD, C. Pharmacokinetics of antimony during sodium stibogluconate therapy for cutaneous leishmaniasis. Clin. Pharmacol. Ther., v.29, p.270-271, 1981.

PAREDES, R.; MUÑOZ, J.; DIAZ. I.; DOMINGO, P.; GURGUI, M.; CLOTET, B. Leishmaniasis in HIV infection. J. Postgrad. Méd.,v. 49, p.39-49, 2003.

PAUMGARTTEN, F.J.R.; CHAHOUD, I. Embryotoxicity of meglumine antimoniate in the rat. Reprod. Toxicol., v. 15, p.327-331, 2001.

PETIT DE PEÑA, Y.; GALLIGNANI, M.; BURGUERA, M.; BURGUERA, J.L.; AÑEZ, A.; LUGOY., A. Selective determination of antimony (III) and antimony(V) in blood serum and urine by hydride generation and atomic absorption spectrometry. J. Braz. Chem. Soc., v.1, p.72-75, 1990.

POLLARD, J. W. Trophic macrophages in development and disease. Nat. Rev. Immunol., v. 9, p. 259-70, 2009.

RATH, S.; JARDIM, F. W.; DOREA, J. G. A simple spectrophotometric procedure for the determination of antimony (III) and (V) in antileishmanial drugs. Fresenius J. Anal. Chem., v. 358, p. 548-550, 1997.

RATH, S.; TRIVELIN, L. A.; IMBRUNITO, T. R.; TOMAZELA, D. M.; JESUS, M. N. DE; MARZAL, P. C.; ANDRADE JR., H. F. DE; TEMPONE, A. G. Antimoniais empregados no tratamento da leishmaniose:estado da arte. Quim. Nova, v.26, p.550$555,2003$.

REES, P.H.; KEATING, M.I.; KAGER, P.A.; HOCKMEYER, W.T. Renal clearance of pentavalent antimony (sodium stibogluconate). Lancet, v.2, p.226-229, 1980.

REITHINGER, R.; DUJARDIN, J.; LOUZIR, H.; PIRMEZ, C.; ALEXANDER, B.; BROOKER, S. Cutaneous leishmaniasis. Lancet, v. 7, p. 581-96, 2007.

RIBEIRO, R. R.; MOURA, E. P.; PIMENTEL, V. M.; SAMPAIO, W. M.; SILVA, S. M., SCHETTINI, D. A.; FERDINAN, C. F. ALVES; MELO, F. A., TAFURI, W. L.; DEMICHELI, C.; MELO, M. N.; FREZARD, F.; MICHALICK, M. S. M. Reduced tissue parasitic load and infectivity to sand flies in dogs naturally infected by Leishmania (leishmania) chagasi following treatment with a liposome formulation of meglumine antimoniate. Antimicrob. Agents Chemother., v. 52, p. 2564-2572, 2008.

ROBERTS, W. L.; RAINEY, P. M. Antileishmanial activity of sodium stibogluconate fractions. Antimicrob. Agents Chemother., v.37, p.1842-1846, 1993. 
ROBERTS, W. L.; BERMAN, J. D.; RAINEY, P. M. In vitro antileishmanial properties of tri- and pentavalent antimonial preparations. Antimicrob. Agents Chemother., v.39, p.1234-1239, 1995.

ROBERTS, W.; MCMURRAY, W. J.; RAINEY, P. M. Characterization of the antimonial antileishmanial agent meglumine antimoniate (glucantime). Antimicrob. Agents. Chemother., v.42,p.1076-1082,1998.

ROMERO, G. A. S.; OLIVEIRA, M. R. F.; DALMO, C.; MARSDEN, P. D. Características físico-químicas do antimoniato de meglumina em diferentes condições de armazenamento. Rev. Soc. Bras. Med. Trop., v.29, p.461-465, 1996.

ROTHKOPF, C.; FAHR, A.; FRICKERB, G.; SCHERPHOF, G. L.; KAMPS, J. A. A. M. Uptake of phosphatidylserine-containing liposomes by liver sinusoidal endothelial cells in the serum-free perfused rat liver. Biochim Biophys Acta, v. 1668, p. 10-16, 2005.

SAIKI, M.; VASCONCELLOS, M. B. A.; ARAUZ, L. J. DE; FULFARO, R. Determination of trace elements in human head hair by neutron activation analysis. J. Radioanal. Nucl. Chem., v. 236, p. 25-28, 1998.

SANTOS, D. O.; COUTINHO, C. E. R.; MADEIRA, M. F.; BOTTINO, C.G.; VIEIRA, R.T.; NASCIMENTO, S. .B.; BERNARDINO, A.; BOURGUIGNON, S. C.; CORTE-REAL, S.; PINHO, R.T.; RODRIGUES, C. R.; CASTRO, H. C. Leishmaniasis treatment-a challenge that remains: a review, Parasitol. Res., v. 103, p. 1-10, 2008.

SANTOS, N. C.; CASTANHO, M. A. R. B. Lipossomas: a bala mágica acertou? Quim. Nova, v. 25, p. 1181-1185, 2002.

SCHERPHOF, G. L.; KAMPS, J. A. The role of hepathocytes in the clearance of liposome from the blood circulation. Progress Lip. Res., v. 40, p.149-166, 2001.

SCHETTINI, D. A.; COSTA VAL, A. P.; SOUZA, L. F.; DEMICHELI, C.; ROCHA, O. G. F.; MELO, M. N.; MICHALICK, M. S. M.; FRÉZARD, F. Distribution of liposome-encapsulated antimony in dogs. Braz. J. Med. Biol. Res., v. 36, p. 269-272, 2003.

SCHETTINI, D. A.; COSTA VAL, A. P.; SOUZA, L. F.; DEMICHELI, C.; ROCHA, O. G. F.; MELO, M. N.; MICHALICK, M. S. M.; FRÉZARD, F. Pharmacokinetic and parasitological evaluation of the bone marrow of dogs with visceral leishmaniasis submitted to multiple dose treatment with liposome-encapsulated meglumine antimoniate. Braz. J. Med. Biol. Res., v. 38, p. 1879-83, 2005. 
SCHETTINI, D. A.; RIBEIRO, R. R.; DEMICHELI, C.; ROCHA, O. G. F.; MELO, M. N.; MICHALICK, M. S. M.; FRÉZARD, F. Improved targeting of antimony to the bone marrow of dogs using liposomes of reduced size. Int. J. Pharmac., v. 315, p. 140-147, 2006.

SCHWENDENER, R. A. Liposomes in biology and medicine. In: Bio-Applications of Nanoparticles. Ed Warren C. W. Chan, v.620, p. 117-128, 2007.

SCHROIT, A. J.; MADSEN, J.; NAYAR, R. Liposome-cell interactions: in vitro discrimination of uptake mechanism and in vivo targeting strategies to mononuclear phagocytes. Chem Phys Lipids, v. 40, p. 373-393, 1986.

SERENO, D.; CAVALEYRA, M.; ZEMZOUMI, K.; MAQUAIRE, S.; OUAISSI,A.; LEMESRE, J.L. Axenically grown amastigotes of Leishmania infantum used as an in vitro model to investigate the pentavalent antimony mode of action. Antimicrob. Agents Chemother., v.42, p.3097-3102, 1998.

SHAKED-MISHAN, P.; ULRICH, N.; EPHROS, M.; ZILBERSTEIN, D. Novel intracellular $\mathrm{Sb} \mathrm{V}$ reducing activity correlates with antimony susceptibility in Leishmania donovani. J. Biol. Chem., v.276, p.3971-3976, 2001.

SINGH, S.; SIVAKUMAR, R. Challenges and new discoveries in the treatment of leishmaniasis. J. Infect. Chemother., v.10, p.307-315, 2004.

SMITH, J. E.; MINSKI, M. J.; RAO, L. S. Assay of antimonial compounds by activation analysis: it use in monitoring the clearance of free and liposomally-entrapped sodium stibogluconate by isolated perfused rat liver. Ann. Trop. Med. Parasitol., v. 80, p. 143-145, 1986.

STAUBER, L.A.; FRANCHINO, E. M.; GRUN, J. An eight-day method for screening compounds against Leishmania donovani in golden hamsters. J. Protozool., v.5, p.269-273, 1958.

STEWART, J.C.M. Colorimetric determination of phospholipids with ammonium ferrothiocyanate. Anal. Biochem., v.104, p.10-14, 1980.

SUNDAR, S.; RAÍ, M. Advances in the treatment of leishmaniasis. Curr. Opin. Infect.

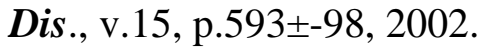

SZOKA, F. JR.; PAPAHADJOPOULOS, D. Procedure for preparation of liposomes with large internal aqueous space and high capture by reverse-phase evaporation. Proc. Natl. Acad. Sci. USA, v. 75, p.4194-8, 1978. 
TADA, H.; SHIHO, O.; KUROSHIMA, K.; KOYOMA, M.; TSUKAMOTO, M. An improved colorimetric assay for interleukin 2. J. Immunol. Methods, v.93, p.157$165,1986$.

TASSI, P.; ORMAS, P.; MADONNA, M.; CARLI, S.; BELLOLI, C.; DE NATALE, G.; CECI, L.; MARCOTRIGIANO, G.O. Pharmacokinetics of N-methylglucamine antimoniate after intravenous, intramuscular and subcutaneous administration in the dog. Res. Vet. Sci., v.56, p.144-150, 1994.

TEMPONE, A. G.; PEREZ, D.; RATH, S.; VILARINHO, A. L.; MORTARA, R. A.; ANDRADE JR, H.F. DE. Targeting Leishmania (L.) chagasi amastigotes through macrophage scavenger receptors: the use of drugs entrapped in liposomes containing phosphatidylserine. J. A. C., v.26, p.1-9, 2004.

TEMPONE, A. G.; SILVA, A. C. M. P. DA; BRANDT, C. A.; MARTINEZ, F.S.; BORBOREMA, S. E. T.; SILVEIRA, M. A. B. DA; ANDRADE JR, H. F. DE. Synthesis and antileishmanial activities of novel 3-substituted quinolines.

Antimicrob. Agents Chemoth., v. 49, p. 1076-1080, 2005 a.

TEMPONE, A. G.; BORBOREMA, S. E.T.; ANDRADE JR, H. F. DE; GUALDA, N. C. A. DE; YOGI, A.; CARVALHO, C. S; BACHIEGA, D.; LUPO, F. N.; BONOTTO, S. V.; FISCHER, D. C. H. Antiprotozoal activity of Brazilian plant extracts from isoquinoline alkaloid-producing families. Phytomedicine, v. 12, p. 382-390, 2005 b.

TEMPONE, A. G.; ANDRADE JR, H. F. De. Nanoformulations of pentavalent antimony entrapped in phosphatidylserine-liposomes demonstrate highest efficacy against experimental Visceral Leishmaniasis. Rev. Inst. Adolfo Lutz, v. 67, p. 131-136, 2008.

TIWARI, K. K.; MUNDHARA, G. L.; RAI, M. K., GUPTA, V. K. A simple and sensitive analytical method for the determination of antimony in environmental and biological samples. Anal. Sci. v.22, p. 259-62, 2006.

TORCHILIN, V. P. Recent advances with liposomes as pharmaceutical carriers. Nat., v. 14, p .45-160, 2005.

TRIVELIN, L. A.; ROHWEDDER, J. J. R.; RATH, S. Determination of pentavalent antimony in antileishmaniotic drugs using an automated system for liquid-liquid extraction with on-line detection. Talanta, v.68, p. 1536-1543, 2006.

TROUILLER, P.; OLLIARO, P. L.; TIRRELE, E.; ORBINSKI, J.; LAING, R.; FORD, N. Drug development for neglected diseases: a deficient market and public health policy failure. Lancet, v.359, p.2188-2194, 2002.

UHUMWANGHO, M. U.; OKOR, R.S. Current trends in the production and biomedical aplications of liposomes: a review. J. M. B. R., v. 4, p. 9-21, 2005. 
VALLADARES, J. E.; ALBEROLA, J.; ESTEBAN, M.; ARBOIX, M. Disposition of antimony after the administration of $\mathrm{N}$-methylglucamine antimoniate to dogs. Vet. Rec. v.138, p.181-3, 1996.

VALLADARES, J. E.; FREIXAS, J.; ALBEROLA, J.; FRANQUELO, C.; CRISTOFOL, C.; ARBOIX, M. Pharmacokinetics of liposome-encapsulated meglumine antimoniate after intramuscular and subcutaneous administration in dogs. Am. J. Trop. Med. Hyg. v.57, p.403-406, 1997.

VALLADARES, J. E.; RIERA, C.; GONZALEZ-ENSENYAT, P.; DÍEZ-CASCÓN, A.; RAMOS, G.; SOLANO-GALLEGO, L.; GALLEGO, M.; PORTÚS, M.; FREIXAS, J.; ALBEROLA, J.; ARBOIX, M. Long term improvement in the treatment of canine leishmaniasis using an antimony liposomal formulation. Vet. Parasitol.,v.97,p.15-21, 2001.

VASCOMCELLOS, M. B. A.; BODE, P.; AMMERLAAN, A.K.; SAIKI, M.; PALETTI, G.; CATHARINO, M. G. M.; FÁVARO, D. I. T.; BARUZZI, R.; RODRIGUES, D. A. Multielemental hair composition of Brazilian Indian population groups by instrumental neutron activation analysis. J. Radioanal. Nucl. Chem., v. 249, p. 491494, 2001.

WAGNER, W.; SANDER, S.; HENZE, G. Trace analysis of antimony(III) and antimony $(\mathrm{V})$ by adsorptive stripping voltammetry. Fresenius J. Anal. Chem., v.354, p. 11-15, 1996.

WELDON, J. S.; MUNNELL, J. F.; HANSON, W. L.; ALVING, C. R. Liposomal chemotherapy in visceral leishmaniasis: an ultrastructural study of an intracellular pathway. Z. Parasitenkd., v. 69, p. 415-424, 1983.

YAN, S.; LI, F.; DING, K.; SUN, H. Reduction of pentavalent antimony by trypanothione and formation of a binary and ternary complex of antimony (III) and trypanothione. $\boldsymbol{J}$ .Biol. Inorg. Chem., v.8, p.689-697, 2003

ZEISBERGER, S. M.; ODERMATT, B.; MARTY, C.; ZEHNDER-FJÄLLMAN, A. H. M.; BALLMER-HOFER K.; SCHWENDENER. R. A. Clodronate-liposomemediated depletion of tumour-associated macrophages: a new and highly effective antiangiogenic therapy approach. Br. J. Cancer. v.95, p. $272-281,2006$. 